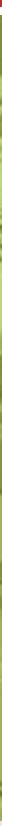

\title{
Distributive impact of public policy
}

Fiscal Studies No. 17 
Established on 1 January 2011, the Deutsche Gesellschaft für Internationale Zusammenarbeit (GIZ) GmbH brings together the long-standing expertise of the Deutscher Entwicklungsdienst (DED) gGmbH (German Development Service), the Deutsche Gesellschaft für Technische Zusammenarbeit (GTZ) GmbH (German technical cooperation) and InWEnt - Capacity Building International, Germany. For the sake of convenience, the new company name GIZ has been used throughout this document.

This study is a reprint of the second part of the publication "Economic Survey of Latin America and the Caribbean 2009-2010", which is issued annually by the Economic Development Division of the Economic Commission for Latin America and the Caribbean (ECLAC). The 2009-2010 edition was prepared under the supervision of Osvaldo Kacef, Director of the Division, with the collaboration of Jürgen Weller and Juan Pablo Jiménez.

The original chapters drew on material written by Jorge Robbio, ECLAC consultant, as well as documents prepared by Olga Lucía Acosta, Oscar Cetrángolo, José María Fanelli, Sebastián Gallegos, Ursula Giedion, Juan Carlos Gómez-Sabaini, Michel Jorrat, Pilar Romaguera, Ramiro Ruiz del Castillo, Jesús Ruiz-Huerta, Andras Uthoff and staff members of the Economic Development Division. This input was discussed at a workshop held in Santiago, Chile, in April 2010, funded by the German Federal Ministry for Economic Cooperation and Development and the GIZ. The final document was presented at a Conference "Public Policy and Distributive Impact" held in Santiago, Chile in August 2010, funded by the German Federal Ministry for Economic Cooperation and Development and GIZ.

\section{Imprint}

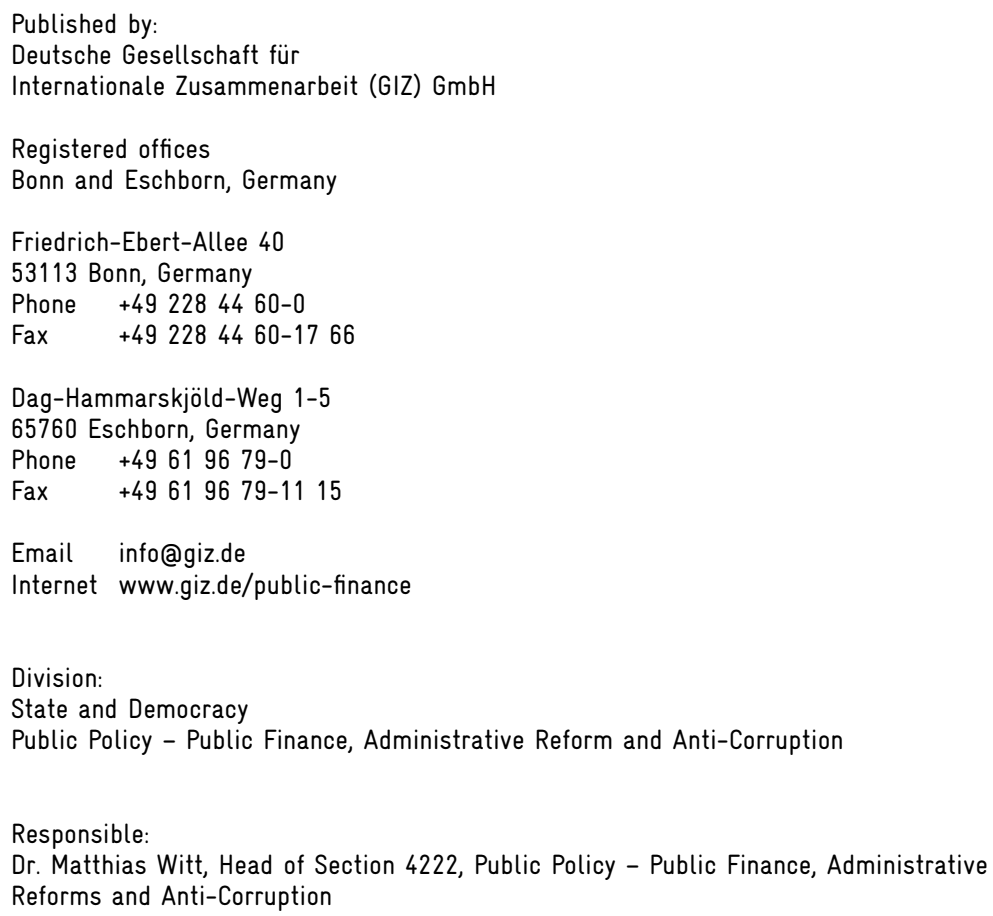

Eschborn, 2011 


\section{Distributive impact of public policy}

\section{Prologue}

The chronic inequality that characterized Latin America and the Caribbean has its roots not only in the region's history but also in a pattern of development and modernization that perpetuated the socio-economic gaps. Very recently, however, the region experienced a period of sustained growth between 2003 and 2008, in which the indicators of poverty, indigence and even concentration of income improved, breaking, although for a short period, the so-called "empty box" of Fernando Fajnzylber.

It is well known that the state can promote greater social equity through more effective public policies. However, as noted in this work, some distinctive features of inequality in our region as the large fraction of total income captured by the highest stratum, the level of geographical disparities and the high levels of poverty, reflect the difficulty in improving equity and cohesion and the complexity of achieving that aim by means of decentralized policies. Most of the times, the poorest areas are exactly those that have the lowest tax bases for funding the priorities of local public spending.

To improve distributive impacts and promote equality and social cohesion in Latin America and the Caribbean, it is important to realize that citizens' social needs are impossible to meet without financial resources. On the revenue size, the region's fiscal systems share two important limitations: low tax pressure and regressive taxation, which, together with large-scale evasion and tax avoidance, all have major effects on equity. On the expenditure size, it is hoped that the structure of the spending financed with the resources available can help to construct more cohesive societies, increasing the legitimacy of public policy and therefore of paying the taxes intended to finance them. Decentralization is an important issue that affects the role of the state in improving the distributive equity, and the expected benefits of decentralization need to be evaluated in the context of the peculiarities of each country.
In order to analyze in detail some aspects of the impact of public policies on equality as discussed in the ECLAC document "Time for equality: closing gaps, opening trails", the Economic Development Division together with GIZ organized a seminar in which the main findings of the thematic chapter of the Economic Survey 2010 were discussed.

The purpose of this activity and this publication is to contribute to the discussion on the impact that public policy can have in strengthening the link between economic growth and distributive equality, a link which has been quite elusive in the region's economic history. The document address important issues as the consequences for income distribution of macroeconomic volatility; the way in which the latter affects the labour market, and the policy options dealing with it; the analysis of the distributive impacts of tax policy and the characteristics and possible impacts of social spending. The conclusion states that public policies must secure the financing needed to improve citizen access to social provisions in a way that combines efficiency with solidarity, relevance and universality, all at the most appropriate level of government.

Inequality remains one of the biggest economic and social challenges in the region and public policy reforms needed to close the social gap require a constant effort to learn and rethink the kinds of intervention needed to overcome poverty and inequality and to increase people's sense of belonging to a growing economy.

\author{
Osvaldo Kacef \\ Director \\ Economic Development Divison, ECLAC
}




\section{Preface}

'The distributive impact of public policy' is a key factor that affects the outcome of all development measures. The present study is therefore of utmost importance for German development policy. In terms of income distribution, Latin America as a region still displays the highest degree of inequality in the world. Consequently, the question of how to shape and implement public policies such that they have a redistributive impact and narrow the gap between rich and poor households is of special relevance for Latin America, and it poses a particular challenge for international cooperation. If we are to develop appropriate recommendations and advisory services and achieve the desired outcomes, we need detailed sectoral analyses. We have to consider not only the content of the policies, but also the context in which these policies are implemented and by whom. Often we observe that deficiencies in policy implementation are not caused by poor policy content, but by insufficient implementation capacities. To ensure the success of public policies and to provide effective support, we must answer two basic questions: Which institutions can implement public policies efficiently and effectively, and how can these institutions adequately address specific target groups?

Following from this, we can see that public policy and good governance are inextricably linked. In this regard, we must consider what capacities are needed to meet all these requirements and how these capacities can be developed together with the relevant stakeholders.

This publication reflects the on-going discussions about equity in Latin America, a topic we consider highly relevant and worthy of greater attention. To make the study accessible to a broader audience, we have supported the reprint of an abridged English version. We are sure the paper will stimulate the ongoing debate on strengthening social cohesion, reducing inequality and improving statesociety relations.

German development cooperation has undergone a fundamental reform. Established on 1 January 2011, the Deutsche Gesellschaft für Internationale Zusammenarbeit (GIZ) GmbH brings together the long-standing expertise of the Deutscher Entwicklungsdienst (DED) gGmbH (German Development Service), the Deutsche Gesellschaft für Technische Zusammenarbeit (GTZ) GmbH (German technical cooperation) and InWEnt Capacity Building International, Germany. The present study is based on discussions that took place on the occasion of a joint event organised by InWEnt and the Economic Commission for Latin America and the Caribbean (ECLAC) in Santiago de Chile. We are proud to present this publication as one of the first to be produced by the new Deutsche Gesellschaft für Internationale Zusammenarbeit (GIZ) GmbH. It showcases the ongoing cooperation measures undertaken by GIZ forerunner organisations InWEnt and GTZ with ECLAC, the most important regional organisation in Latin America. This cooperation and partnership will continue to be of crucial importance for GIZ in the future.

\section{Dr Elke Siehl}

Director of the State and Democracy Division GIZ

Dr Günther Taube

Director of the Good Governance and Social Development Department GIZ 


\section{Distributive impact of public policy}

\section{Content}

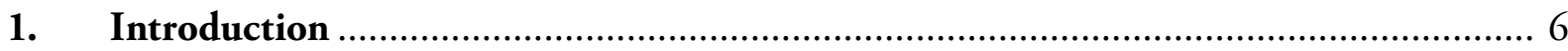

2. Macroeconomic volatility, employment and income distribution ........................... 10

2.1 Characteristics of volatility in Latin America and the Caribbean ............................. 10

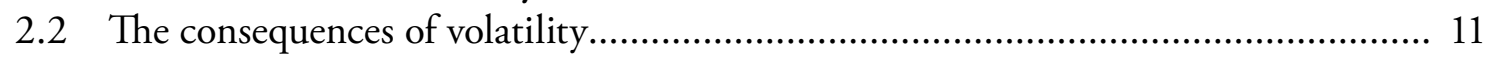

2.3 Characteristics of growth and its distributive impact ........................................ 15

3. The distributive impact of public policy and financing ....................................... 19

3.1 Taxation as a distributive policy tool ........................................................... 19

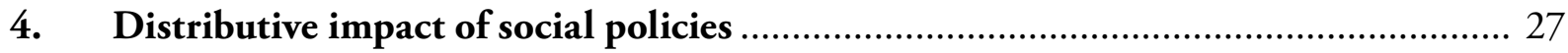

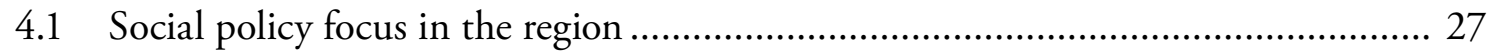

4.2 Social policies in the areas of pensions, health and education............................... 31

4.3 Assigning functions to different levels of government ........................................ 37

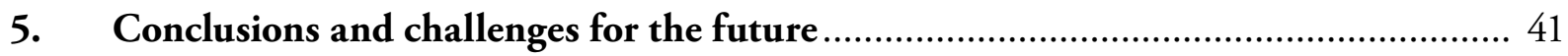

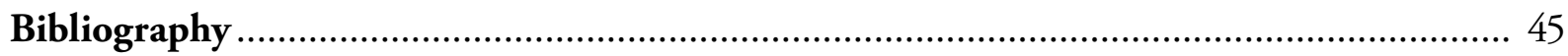

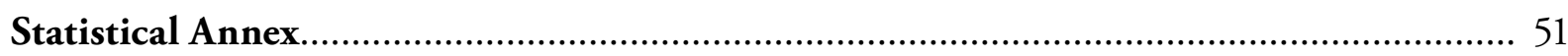




\section{Distributive impact of public policy}

\section{Introduction}

The purpose of this part of the document is to contribute to discussions of the impact that public policy can have in strengthening the link between economic growth and distributive equity, a link which has been quite elusive in the region's economic history. The difficulties encountered in Latin America and the Caribbean in terms of consolidating that link are reflected in the idea of an empty box, taken from a work by Fernando Fajnzylber (Torres Olivos, 2007). In the early 1990s, Fajnzylber constructed a double-entry table in which he placed the Latin American countries according to their performance in respect of two variables: the income concentration index and the growth rate. Only one box remained empty, the one which combined high growth with low inequality; that was the source of the idea of the "empty box" as a chronic deficit in the region and a challenge which still faces its analysts and policymakers.

The chronic inequality affecting Latin America and the Caribbean has its roots in the region's history, going back to the privileges of the elite during colonial times, and the denial of rights to the great majority of the population according to racial and class categories. This situation reduced most of the people of the continent to slavery at that time. During the republican period, privilege continued to be reproduced through other means such as unequal access to land ownership, concentration of movable wealth, scant development of public education and health care, and racial discrimination; lastly, the pattern of development and modernization perpetuated socio-economic gaps based on racial and ethnic origin, social class and gender. Productive structures and educational opportunities reinforced patterns of reproduction of inequality, and to a great extent are still doing so. The region shows levels of inequality in personal income distribution which are much higher than in the other regions of the world, with an average Gini coefficient of 0.53; as can be seen in figure 1, this has remained practically unchanged for 20 years. The information contained in figure 2 confirms the situation of serious inequality in the region, where all the Latin American countries have Gini indices above 0.4 ; in most of them the indicator is over 0.5 . The region's least unequal country is more unequal than any of the Organisation for Economic Co-operation and Development $(\mathrm{OECD})$ countries or any State in the Middle East or North Africa.

A distinctive feature of the inequality in the region is the large fraction of total income captured by the highest stratum, that is, the richest decile of households, as shown in figure 3 . That decile averages $35 \%$ of total income, although there is considerable variation around this value. While in the Bolivarian Republic of Venezuela and Uruguay the share of the top decile is $28 \%$ of the total, the figure exceeds $40 \%$ in Brazil and Colombia. At the opposite extreme, the stratum consisting of the poorest $40 \%$ of households averages $15 \%$ of total income. The lowest figure is for Honduras, where it is below $10 \%$. While the gaps between intermediate deciles are less pronounced, there is a very clear discrepancy between the highestincome decile and the second. In the European countries the income of the tenth decile is $20 \%$ to $30 \%$ more than that of the ninth, in Latin America that gap tends to be over $100 \%$ and in some cases it comes close to $200 \%$. of the tenth decile is $20 \%$ to $30 \%$ more than that of the ninth, in Latin America that gap tends to be over 100\% and in some cases it comes close to $200 \%$.

Figure 1

GINI COEFFICIENTS BY GROUPS OF COUNTRIES

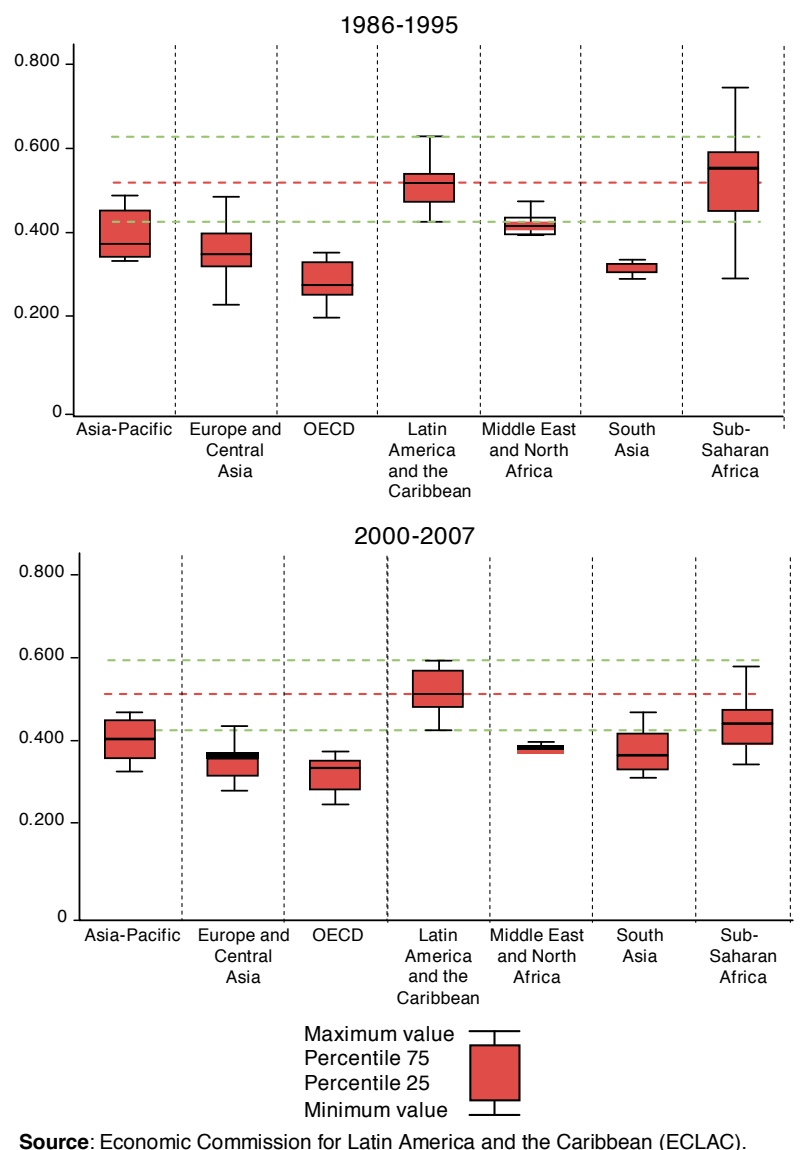

Source: Economic Commission for Latin America and the Caribbean (ECLAC). 
Figure 2

OECD AND LATIN AMERICA: GINI INEQUALITY INDICES 2003-2008

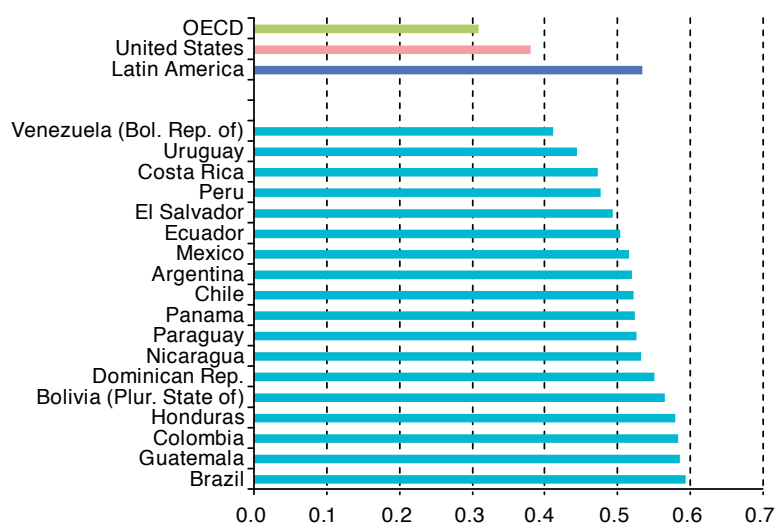

Source: Economic Commission for Latin America and the Caribbean (ECLAC) and Organisation for Economic Co-operation and Development (OECD)

A further dimension of inequality in Latin America, of particular interest for policy design, is the level of geographical inequality. To illustrate, figure 4 compares the per capita GDP gap in the richest and poorest geographical areas with per capita GDP for a series of European and Latin American countries. With the exception of the smallest Central American countries and Uruguay (the latter having the best indicators of equity and a clearly unitary organization), the gaps are very large, unequalled in any European country. The per capita GDP of Europe's richest area is almost double that of the lowest-income area in the same country, in Latin America that ratio is about six.

Figure 3

LATIN AMERICA (18 COUNTRIES): INCOME DISTRIBUTION BY DECILE, AROUND $2007^{a}$

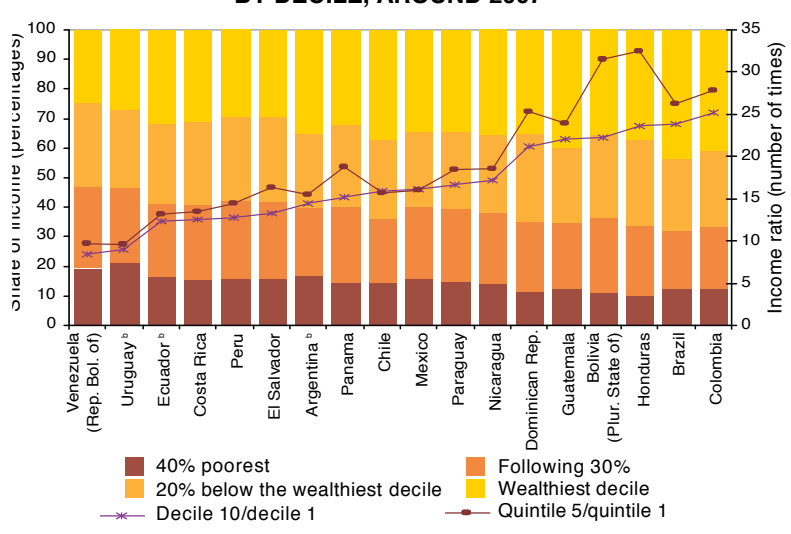

Source: Economic Commission for Latin America and the Caribbean (ECLAC), Social Panorama of Latin America, 2008 (LC/G.2402-P), Santiago, Chile, March 2009. United Nations publication, Sales No. E.08.II.G.89.

a Households ordered by per capita income.
Figure 4

LATIN AMERICA AND EUROPE (SELECTED COUNTRIES): RATIO OF HIGHEST TO LOWEST PER CAPITA GDP WITHIN THE SAME GEOGRAPHICAL AREA AND PER CAPITA GDP

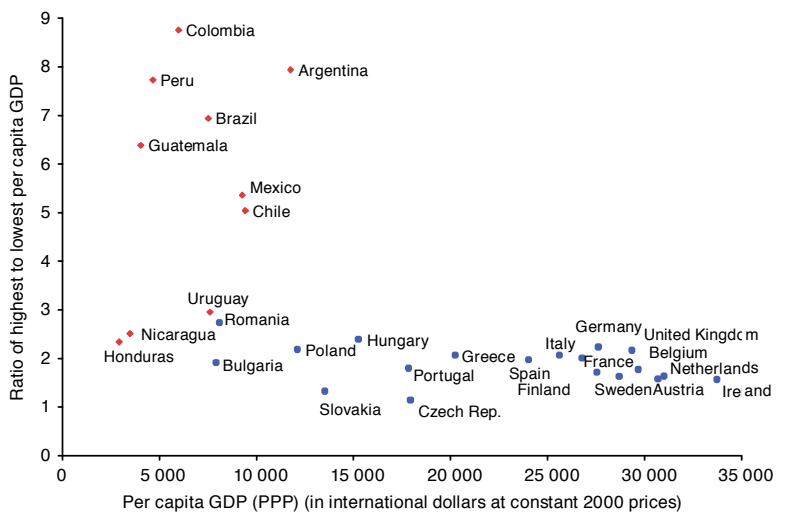

Source: Economic Commission for Latin America and the Caribbean (ECLAC), on the basis of Oscar Cetrángolo, "Búsqueda de cohesión social y sostenibilidad fiscal en los procesos de descentralización", Políticas sociales series, No. 131 (LC/L.2700-P), Santiago, Chile, Economic Commission for Latin America and the Caribbean (ECLAC), 2007. United Nations publication, Sales No. S.07.II.G.50.

These indicators reflect the difficulty of the task of improving equity and cohesion and show the complexity of achieving that aim by means of decentralized policies, since the poorest areas are exactly those which have the lowest tax bases for funding the priorities of local public spending (such as infrastructure, health care and education). Levels of poverty are another important variable in seeking to understand the situation of the Latin American countries, in terms of their ability to generate resources for meeting the needs of the population and designing public policies to contribute to greater equity. According to the Social Panorama of Latin America, 2008 (ECLAC, 2008), the latest available estimates for the Latin American countries show that in 2008, 33\% of the population were living in poverty. Extreme poverty (indigence) affected $12.9 \%$ of the population. The total number of people living in poverty was 182 million, of whom 71 million were indigent.

Poverty indicators vary substantially among the countries of the region. The lowest levels of poverty are to be found in Argentina, Chile, Costa Rica and Uruguay, with poverty rates below $22 \%$ and indigence rates between $3 \%$ and $7 \%$, whereas the countries with the highest levels of poverty and indigence, exceeding 50\% and 30\%, respectively, are Guatemala, Haiti, Honduras, Nicaragua, Paraguay and the Plurinational State of Bolivia. The high rates of poverty and indigence in these countries have a major impact on the ability of the public sector to collect taxes, and this restricts the availability of resources for implementing policies to meet the basic needs of the poorest segments of society. 
Figure 5

LATIN AMERICA: POVERTY AND INDIGENCE, 1980-2008 (Percentages)

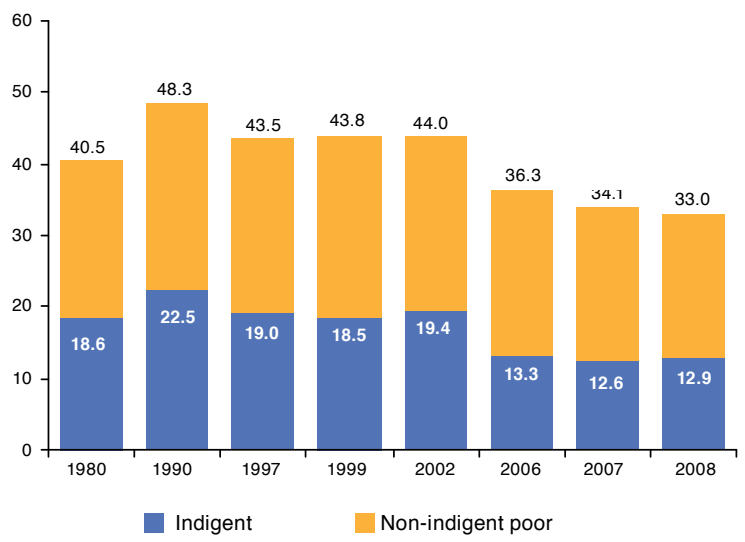

Source: Economic Commission for Latin America and the Caribbean (ECLAC), on the basis of special tabulations of household surveys conducted in the respective countries.

Estimate relating to 18 Latin American countries, plus Haiti. The figures in the upper parts of the bars represent the percentage of poor people (indigent plus non-indigent poor)

An additional dimension to be taken into account is the weight of informality in the economy, an indicator which can reflect the composition of employment and the extent to which various groups are protected, as well as the issue of tax evasion. According to estimates by Schneider and Enste (2000), Latin America has the highest level of informal economic activity of all the world's regions; it is even higher than that in other developing regions. ${ }^{1}$

\section{Figure 6}

\section{THE WORLD: THE INFORMAL SECTOR,} AVERAGES FOR 2002-2003

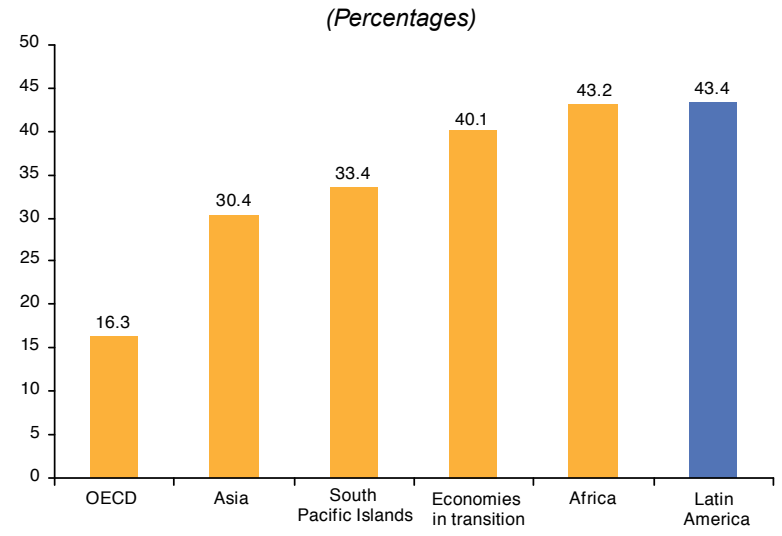

Source: Economic Commission for Latin America and the Caribbean (ECLAC), on the basis of Friedrich G. Schneider, "Shadow economies and corruption all over the world: what do we really know?", Economics Working Papers, No. 2006-17, Department of Economics, Johannes Kepler University, Linz, 2006.

1 Schneider and Enste note that studies seeking to measure the underground economy are faced, first, with the difficulty of defining it. The underground economy, also known as the parallel or informal economy, includes not only illicit activities but also undeclared income from the production of lawful goods and services, involving monetary transactions and barter.
As the Economic Commission for Latin America and the Caribbean (ECLAC) has noted in other publications, the period of sustained growth in the region from 2003 to 2008 saw poverty and indigence fall by eleven and six percentage points, respectively, while income concentration also fell slightly. These improvements were brought about mostly by labour-market forces and, to a lesser extent, by trends in demographic variables (falling dependency rates), as well as increases in transfers received by households. Beyond these positive data, the evidence shows that there are still broad social gaps based on two major dimensions: first, the capacity of the labour market to generate income which can sustain the members of society, and second, the capacity of States to support and protect dependants, that is, those who have no income or whose employment incomes are insufficient.

The countries with the smallest social divides are those which have high GDP, lower demographic dependency rates, less informality in their labour markets, and greater social security coverage. The public sector also plays a greater role in those countries, in terms of the provision of health services (smaller proportions of out-of-pocket expenditure) and in relation to social spending, which is greater not only in per capita terms, but also as a percentage of GDP.

Direct intervention by the State through the level and structure of its tax receipts, as well as monetary transfers to low-income groups, has a significant incidence on income distribution and poverty. In the OECD countries, the estimated Gini coefficient before taxes and transfers is 0.45 , but it falls to 0.31 following the redistributive action of the State. On the other hand, ECLAC (2010) shows that in some Latin American countries the equivalent variation of the Gini index is between half and a third of that observed in the developed countries.

This is because most Latin American countries have low tax burdens, regressive tax structures and inappropriate orientation of public social spending. The countries of the region are faced with the challenges of boosting the receipts they collect and also of improving the impact of taxation on income distribution, increasing the burden on the wealthier sectors. At the same time, it is hoped that the structure of the spending financed with those resources can help to construct more cohesive societies, increasing the legitimacy of public policy and therefore of paying the taxes intended to finance them. Demand for more public spending is not limited to the social sphere, however; it can include other areas which, like public investment or productive development policies, have an impact on competitiveness, on production profiles, and consequently on growth rates and the way in which their fruits are distributed.

As will be seen in chapter I of this part of the document, although there can be no doubt that macroeconomic 
stability is necessary for the region to be able to grow more and share better, that stability goes beyond ensuring low and stable inflation rates; it must take account of the need to reduce real instability. To achieve this, macroeconomic policy design should consider the need to deal with the fluctuations associated with economic cycles, avoiding excessive instability in the level and quality of services provided by the State, and of key variables such as the real exchange rate and interest rates. Furthermore, it is a very important goal for low-income groups, whose spending

is restricted by their low saving capacity and limitations on their access to the financial market.

The opportunity that many of the countries of the region have had recently to implement a variety of measures to alleviate the impact of the worldwide crisis on economic activity and the social situation has revalued the role of the State and of active policies; however, at the same time, it exposed the huge differences between the countries of the region in terms of their capacity to implement those policies. This has underlined the importance of broadening the public policy domain, strengthening instruments to follow up the agreed goals, ensuring the availability of any resources needed for financing the initiatives to be put into practice and strengthening the institutions responsible for implementing them.

This document will focus on the distributive impact of a limited set of public policies. Chapter I will consider the consequences for income distribution of macroeconomic volatility, the way in which the latter affects the labour market, and policy options for dealing with it. Chapter II is dedicated to analysis of the distributive impacts of tax policy, and chapter III deals with social spending. Lastly, chapter IV will take stock and draw overall conclusions.

The fact that the analysis focuses on certain aspects of public policy imposes certain constraints. First, the distributive effects of other elements of public spending aside from social spending will not be considered; neither will the indirect effects of general fiscal strategy or other macroeconomic areas such as interest-rate or exchange- rate policies. The second limitation of the analysis is that distributive incidence and impacts will always be dealt with in a static manner and from the viewpoint of partial equilibrium. The analysis of the distributive impact of education or health-care spending, for example, does not consider its possible effects on the potential future earnings of the recipients. Also not taken into account are the possible interactions among the various policies analysed, nor between them and the behaviour of economic agents and their subsequent distributive impacts. 


\section{Macroeconomic volatility, employment and income distribution}

\begin{abstract}
Macroeconomic policy analysis makes little reference to distributive issues, yet this area of policymaking often has major implications for distribution, which generate complex dilemmas between actions which have different impacts on various social groups. It is therefore important to consider the possible distributive impacts of the different tools of macroeconomic policy, such as the management of monetary aggregates, the level and composition of public spending, or the proportion of revenue obtained from different types of taxation.
\end{abstract}

As mentioned above, the concern of ECLAC with macroeconomic stability is not limited to the need to achieve the lowest and most stable inflation possible; it is also aware of the huge costs of real instability in Latin America, not only from the growth perspective, but also in terms of its impact on poverty and inequality. Thus, as Raúl Prebisch wrote more than 60 years ago: "Anti-cyclical policies must be included in any programmes of economic development if there is to be an attempt, from a social point of view, to raise real income. The spread of the cyclical fluctuations of the large centres to the Latin-American periphery means a considerable loss of income to these countries. If this could be avoided, it would simplify the problem of capital formation. Attempts have been made to evolve an anti-cyclical policy, but it must be admitted that, as yet, but little light has been thrown on this subject" (Prebisch, 1950).

\subsection{Characteristics of volatility in Latin America and the Caribbean}

An analysis of aggregate fluctuations in Latin America and the Caribbean shows that the region has shown very high volatility compared with more developed countries. The variance of the growth rate in 1951-2008 in Latin America is $50 \%$ higher than in Europe and the United States (Kacef and Jiménez, 2010).

At the same time, as figure $7 .^{2}$ shows, there have frequently been episodes which may be described as crises, some of which have sharply curtailed growth or even caused a production collapse, that is, a drop in the absolute value of per capita GDP.1 There have also been frequent shocks which altered long-term trends, contrasting with temporary turmoil which, by definition, is followed by a return to the mean.

Economists who subscribe to structuralist theories have argued repeatedly that fluctuations in the region's

2 ECLAC (2008) offers a number of relevant definitions. economies are closely related to external shocks (such as sudden trend reversals in capital flows or sharp variations in the terms of trade). ${ }^{3}$ Such fluctuations tend to be accompanied by changes in the sustainability prospects for public and external debt and increased fragility in the financial system. They have often led to adjustment processes, often including major shifts in relative prices (and, therefore, in income distribution) and in the organizational structures of economic activity (private contracts, public regulation, property rights).

Macroeconomic volatility, as a source of or the reflection of underdevelopment (Chang, Kaltani and Loayza, 2009) has therefore been a subject of particular interest in analysing the external performance of the Latin American and Caribbean region. Level of macroeconomic volatility is associated with a variety of elements, which differ according to each country's specific features, including its pattern of international integration, productive structure, economic policy, vulnerability to natural disasters and institutional framework (ECLAC, 2004, 2008).

A number of studies have found a negative correlation between volatility and GDP growth. While the channels interconnecting these variables are not easy to identify, there is a degree of consensus that sharp variations in investment play a key role. ${ }^{4}$ Given the imperfect credit markets common in peripheral economies, the fall in investment during the recessionary phase of the cycle exceeds the upturn that ensues during the expansionary phase, resulting in a negative balance. Increased risk aversion among investors during turbulent periods in the region, when crises involve several countries at the same time, can put abrupt an end to slow-maturing projects, damaging investment efficiency.

\footnotetext{
3 ECLAC has emphasized these links since its beginnings (see Prebisch, 1949 and Rodríguez, 2006).
}

4 See ECLAC (2008) and the bibliography quoted therein. 
Figure 7

NORMAL VOLATILITY AND EXTREME VOLATILITY (CRISIS) IN PER CAPITA GDP GROWTH, 1961-2009 a

(Percentages)

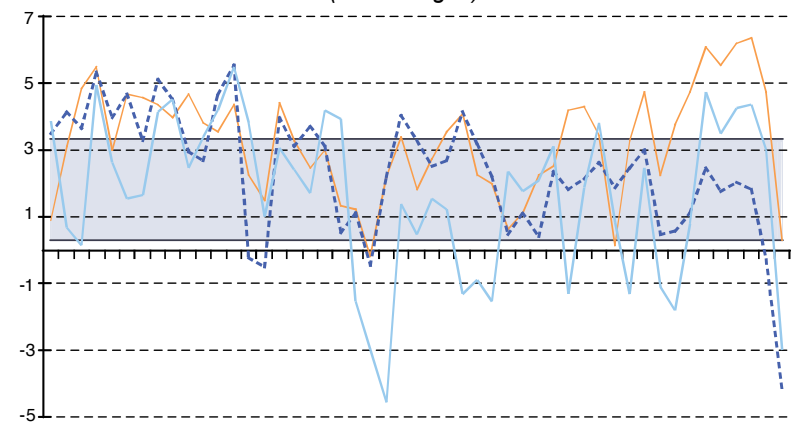

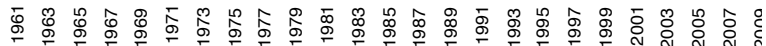
- Developing countries, excluding Latin America

Source: Economic Commission for Latin America and the Caribbean (ECLAC).

a Volatility is considered to be extreme when per capita GDP varies by a percentage which is less than the worldwide figure minus one standard deviation during the period under consideration. This range corresponds to the shaded area in the figure.

Another stylized fact is that consumption is more volatile than GDP in Latin America and the Caribbean (Toledo, 2008). The high volatility of consumption means that poverty rates are also very changeable, particularly when there is a high density of households with per capita incomes close to the poverty line. In these circumstances, falling incomes and consumption can leave large numbers of people below the poverty or indigence line.

\subsection{The consequences of volatility}

\section{For well-being}

The impact of volatility on well-being is measured in terms of falling per capita consumption resulting from slower economic growth. Volatility causes creation and destruction of wealth through changes in relative prices and in property rights. The uncertainty this causes discourages investment and holds down growth and employment.

When consumption is more volatile than income, as is the case in the region, the same is true of the impact on wellbeing. ${ }^{6}$ Furthermore, as mentioned above, highly volatile consumption means highly volatile poverty, especially where there are many households with per capitaincomes close to the poverty line. In these conditions, a relatively sharp fall in consumption can leave many people below the minimum income level needed in order to satisfy their needs. Two examples illustrate this connection: Mexico, where the crisis of 1995 raised the percentage of poor from $45.1 \%$ in 1994 to

5 For more detail, see Kacef and Jiménez (2010).

6 Pallage and Robe (2001) note that the volatility of consumption has a high cost for developing countries. To bring that volatility to the same level as in the developed countries would be equivalent to increasing the GDP growth rate by 0.34 percentage points in perpetuity.
52.9\% in 1996; and Argentina, where the 2002 crisis pushed up urban poverty from $23.7 \%$ in 1999 to $45.4 \%$ in 2002 (ECLAC, 2007).

\section{For the labour market and income distribution}

In a region which, like Latin America and the Caribbean, is characterized by sharp inequalities and marked unevenness in the access of different social groups to the goods and services produced in the economy, equity cannot be increased without considering the differential impacts of volatility on the well-being of different income groups. From a macroeconomic perspective, this unevenness has a number of dimensions, beyond the vulnerability, as mentioned of the lowest income groups to fluctuations in consumption due to their proximity to the subsistence level. One of these dimensions has to do with the differential impacts of volatility on employment (Weller, 2010).

Both theoretical arguments and empirical evidence show that high volatility in economic growth is counterproductive, both for the generation of quality employment and for equality. ${ }^{7}$ The literature on human capital notes that in many cases, workers' skills are acquired by practice, during the actual production process. Some of that increased human capital is specific to the post and to the technology of the particular place of work, so it is likely to lose its value when the worker changes jobs. As a result, high rotation resulting from high macroeconomic volatility has a depressing effect on workforce productivity and income.

Even in periods of relative macroeconomic stability, however, the region's labour markets show high levels of rotation. ${ }^{8}$ It is sometimes argued that this facilitates reassignment of the workforce from declining enterprises and sectors towards new sectors and expanding businesses. Empirical data, however, show that during the structural reform period, intersectoral labour migrations in Latin America and the Caribbean did not take place from low-productivity to high-productivity segments, but the reverse (Pagés, Pierre and Scarpetta, 2009).

Not all workers are hit equally hard by job losses during periods of economic instability. Businesses are usually more interested in keeping their more highly-skilled workers but, with regard to less-skilled workers, tend to adopt profitmaximizing strategies involving increased use of short-term contracts and outsourcing. Thus, at the microeconomic level, the speed of rotation (Cowan and Micco, 2005), and less educated workers suffer greater income instability than their more skilled colleagues (Beccaria and Groisman, 2006).

\footnotetext{
7 See Farber (1999), Auer, Berg and Coulibaly (2005) and Perry and others (2006). 8 See Calderón-Madrid (2000), Cowan and others (2005) and SPTyEL (2005).
} 
Comparison of the volatility of economic growth with that of real wages and unemployment rates for the period from the early 1990s to 2006 shows a number of patterns of labour-market adjustment among the Latin American countries. Figure 8 shows that in Chile, Guatemala and Peru, there are strong correlations both between the volatility of economic growth and that of the unemployment rate, and between the volatility of the growth rate and that of real wages. In Costa Rica and Uruguay the correlation is greater in the case of unemployment (adjustment resting more on variations in employment levels); this is also the case in Colombia and Panama, where the correlation in the case of wages is actually negative.

In Brazil, Mexico and Nicaragua the correlation is high for wages but somewhat lower for employment (more adjustment via real wages). Lastly, Argentina, the Bolivarian Republic of Venezuela, Ecuador, Paraguay and the Plurinational State of Bolivia show low or negative correlations in both cases. In those countries, the labour-market adjustment apparently takes place through the informal labour market or emigration.

Figure 8

LATIN AMERICA (15 COUNTRIES): CORRELATION BETWEEN VOLATILITY IN ECONOMIC GROWTH AND IN UNEMPLOYMENT AND AVERAGE REAL WAGES

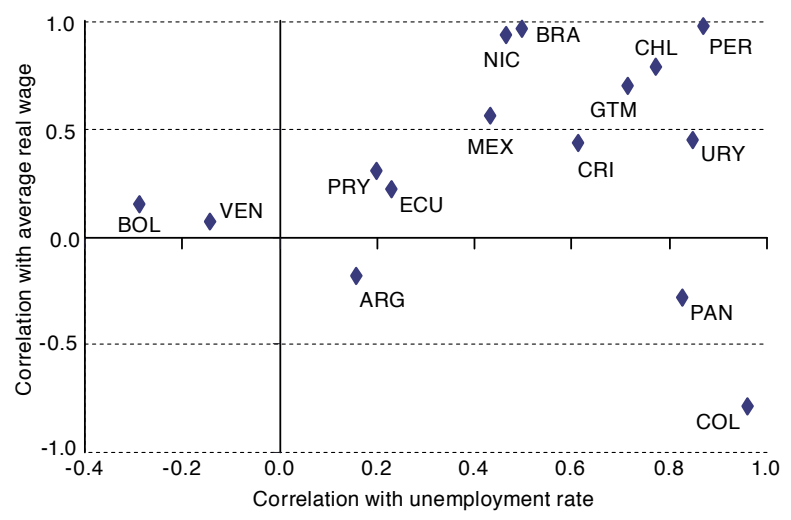

Source: Jürgen Weller, "La flexibilidad del mercado de trabajo en América Latina y el Caribe. Aspectos del debate, alguna evidencia y políticas", Macroeconomía del desarrollo series, No. 61 (LC/L.2848-P/E), Santiago, Chile, Economic Commission for Latin America and the Caribbean (ECLAC), 2007. United Nations publication, Sales No. S.07.II.G.171.

Another dimension of the distributive impact of volatility involves types and levels of market integration (between formality and informality, for example), because of sharp disparities in the effects of policies on different groups. In Latin America and the Caribbean, at times of

9 Other authors, agreeing that there is a variety of adjustment mechanisms in the labour market, have found other patterns. For example, Ros (2006) shows three distinct ways in which, during the period 1990-2002, the countries of the region adapted to the insufficient creation of formal employment: (i) through the expansion of informal jobs (Brazil, Colombia, Honduras, Mexico and Peru); (ii) through the expansion of informality and the growth of unemployment (Bolivarian Republic of Venezuela and Costa Rica); (iii) mainly through higher unemployment (Chile, Ecuador and Uruguay). Ros also mentions that falls in real wages during the same period were not part of the adjustment mechanism. high volatility the incomes of poorer households fluctuate more severely and unemployment is worse among the poorer strata (see figure 9); and that lack of employment opportunities pushes workers towards informality (see figure 10). Those impacts are often long-lasting, since crisis episodes have consequences in terms of employment, poverty and inequity which are remedied only slowly during expansionary periods. Crises also lead many young people from lower-income households to leave the educational system and enter the labour market. This tends to reinforce the perpetuation of poverty and inequality.

The unevenness is also reflected in differences in access to markets, particularly financial markets and, as a result, unequal ability to cushion the impact of volatility. These characteristics imply that high-income and low-income groups have widely differing ranges of choices available to them. In particular, given their capacity for saving and generating stocks of wealth, the high-income groups can diversify their risk-taking in order to protect their capital from internal volatility; they can also use their assets or, possibly, their access to credit, to moderate the impact of income fluctuations on consumption. ${ }^{10}$ In relatively high-inflation economies, they are better able to avoid the resulting tax on cash assets by moving their capital to alternative assets whose value is better protected from the effects of inflation. Low-income groups, on the other hand, are constrained in their opportunities to anticipate and prevent shocks and therefore suffer strong impacts when they occur (Krusell, Kuruscu and Smith, 2002).

Figure 9

LATIN AMERICA (18 COUNTRIES): UNEMPLOYMENT RATE, AROUND 2008

(Percentages of the economically active population)

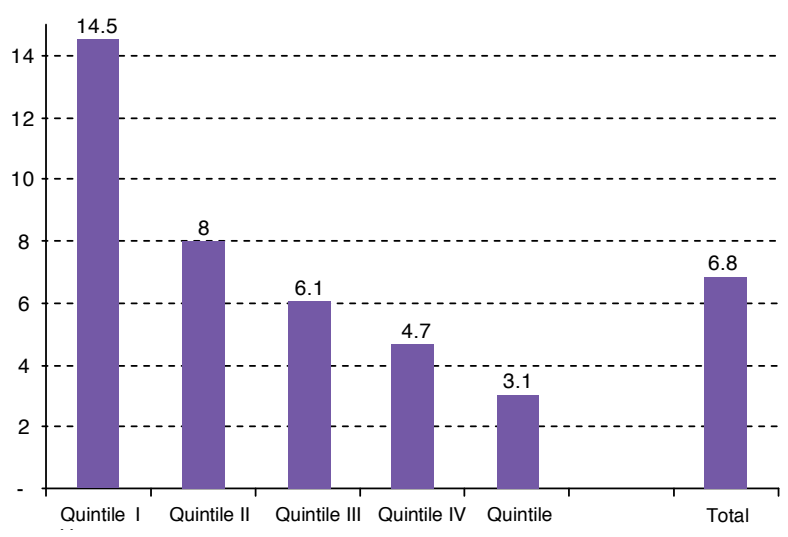

Source: Economic Commission for Latin America and the Caribbean (ECLAC), on the basis of official information from the respective countries.

10 Indeed, given the high concentration of wealth, they have a greater capacity to influence
volatility directly through the impact of their own decisions on saving, investment and the

Indeed, given the high concentration of wealth, they have a greater capacity to influence
volatility directly through the impact of their own decisions on saving, investment and the composition of their investment portfolios. 
Figure 10

LATIN AMERICA (18 COUNTRIES): RATE OF EMPLOYMENT INFORMALITY IN THE URBAN SECTOR, AROUND 2008

(Percentages of total urban employed)

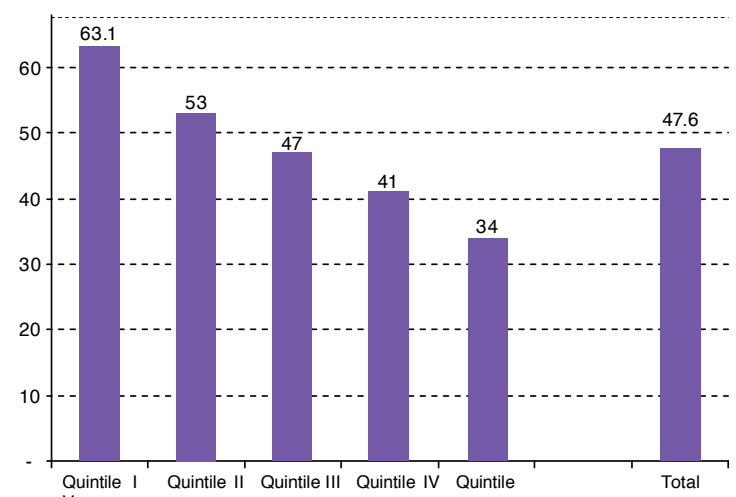

Source: Economic Commission for Latin America and the Caribbean (ECLAC), on the basis of official information from the respective countries.

Through these channels, volatility generates higher inequality (see figure 11). According to a study by Calderón and Levy-Yeyati (2009) for 75 countries, the Gini coefficient is positively and significantly associated with macroeconomic volatility. At the same time, macroeconomic volatility is negatively correlated with incomes in the first three quintiles of income distribution but positively correlated with income in the two highest quintiles.

Figure 11

\section{THE WORLD (75 COUNTRIES):VOLATILITY AND INCOME} DISTRIBUTION, 1975-2005

(Logarithm of Gini coefficient and percentage points)

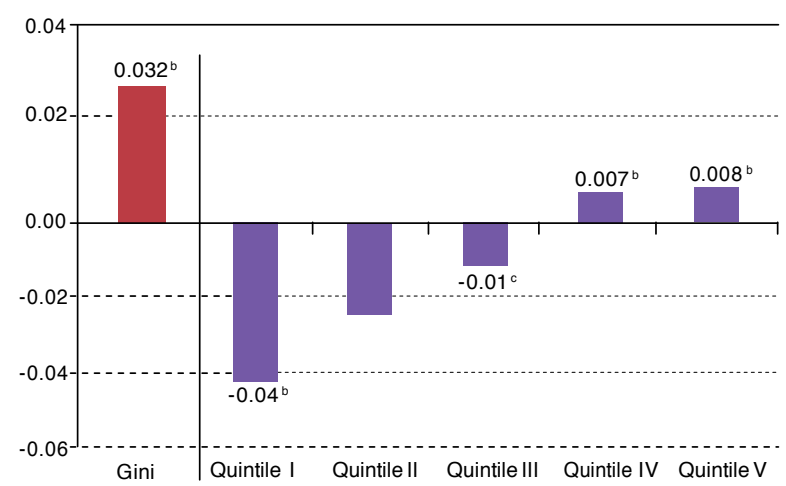

Source: Economic Commission for Latin America and the Caribbean (ECLAC), on the basis of César Calderón and Eduardo Levy-Yeyati, "Zooming in: from aggregate volatility to income distribution", Policy Research Working Paper series, No. 4895, World Bank, 2009.

a These are panel estimates on 75 countries for 1975-2005, with five-year intervals. The dependent variable is the logarithm of the Gini coefficient and the income share per quintile and the independent variable is the deviation of GDP growth. The control variables included are the Gini coefficient $(t-1)$, real income per person, the square of real income per person, the rate of secondary educational enrolment, the rate of inflation and government spending as a percentage of GDP.

Statistically significant at $5 \%$.

Statistically significant at $10 \%$.

\section{For the macroeconomic policy space}

In the Latin America and Caribbean region, the magnitude of policy space can change very quickly after a shock. Macroeconomic volatility shapes the policy area not only by influencing resources, but also by determining the intensity with which other policies compete with those of stabilization, and because it often limits the quantity of policy tools available (for example, during crises the market for new public borrowing may disappear). When a negative shock occurs, as in 2008-2009, demand from the affected sectors increases and there is intensified competition for the use of both resources and policy instruments, which are structurally scarce in the region.

These factors create a two-way relationship between the fiscal function of stabilization and macroeconomic imbalances and shocks: fiscal policies seek to correct imbalances opened up by shocks, but shocks and imbalances constrain policymaking capacity by leaving less room for manoeuvre. Fiscal policy is a good example of this effect. As GDP falls, tax receipts are reduced and the borrowing capacity of the public sector often suffers where access to capital markets is procyclical.

As can be seen in figure 12, tax receipts in the region are highly volatile — volatility is almost three times higher, on average, than in the developed countries, as measured by the standard deviation of these revenues (Gómez-Sabaini and Jiménez, 2009). This volatility has a greater impact on the most vulnerable population segments, through the fluctuations it produces in public social spending. In many countries, tax receipts are doubly affected by external shocks (directly, and also indirectly through the level of economic activity).

All this is worsened by the highly procyclical nature of access to financing for the countries of the region. Together with the combination of scarce and volatile resources and unmet social needs, this generates procyclical spending policies. This is confirmed by the data in figure 13, which shows the 30-year trend in the coefficient of correlation between government spending and GDP. Spending is seen to be increasingly procyclical (at least up to the late 1990s), unlike what has occurred in the developed economies. This implies that in Latin America and the Caribbean the State's capacity to provide welfare assistance falls during recessionary periods (ECLAC, 2006), adding a further element of volatility to the consumption of the poor (de Ferranti and others, 2002) whose incomes are significantly supplemented by social spending (see figure 14). 
Figure 12

LATIN AMERICA AND OECD COUNTRIES: STANDARD DEVIATION OF THE GROWTH OF TAX RECEIPTS (NOT INCLUDING SOCIAL SECURITY), 1980-2008

(Percentages and dollars at constant 2000 prices)

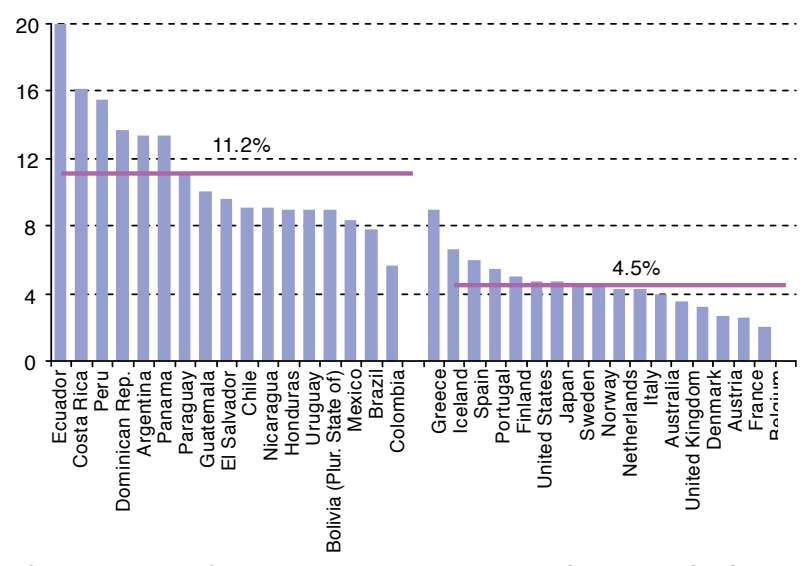

Source: Economic Commission for Latin America and the Caribbean (ECLAC).

Figure 13

LATIN AMERICA: PROCYCLICITY OF GOVERNMENT SPENDING COMPARED WITH THAT OF DEVELOPED COUNTRIES, 1975$2005^{a}$

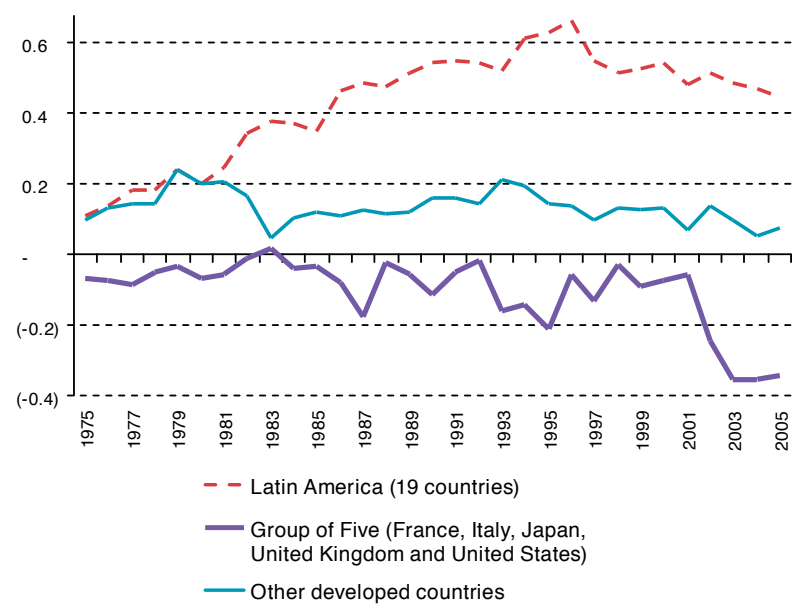

Source: Economic Commission for Latin America and the Caribbean (ECLAC). a For each country, correlation coefficients were calculated between the variation of government spending and that of economic growth, for 15-year moving windows; subsequently, the average of the coefficients was calculated for the countries of each region.
Figure 14

LATIN AMERICA (SIMPLE AVERAGE):

IMPACT OF SOCIAL SPENDING ON PRIMARY HOUSEHOLD INCOME, BY PRIMARY PER CAPITA INCOME QUINTILES, 1997-2004 (Percentages)

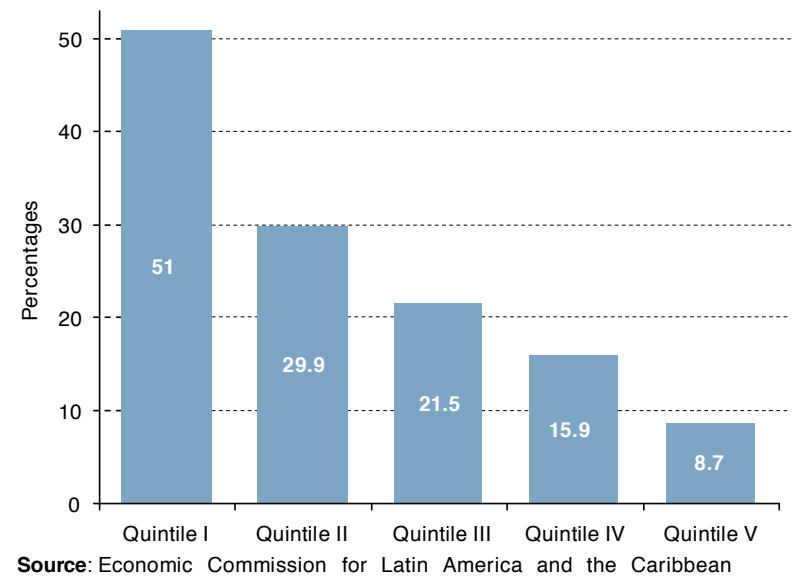
(ECLAC), on the basis of official information from the respective countries.

\section{Macroeconomic volatility and public policies}

As described above, macroeconomic volatility affects the growth and stability of consumption and gives rise to sudden, undesirable changes in income distribution and in the allocation of property rights; as a result, it generally leads to distributive conflicts. Such situations tend to be worsened by the negative impact of macroeconomic volatility on the quantity and quality of public policies. One set of policies may gain ascendance over others, damaging the governance of economic activity (ECLAC, 2008).

This impact of volatility on well-being, income distribution and the macroeconomic domain will affect the political and social situation and produce social tension and distributive conflicts, worsening the instability. Following Alesina and Perotti (1996), who established a causal link between equity, stability in democratic institutions and growth, it could be said that real volatility has an impact at both ends (equity and growth) and creates a vicious cycle which may damage democratic governance. This is why a strategy to improve income distribution must include the generation of fiscal space for implementing policies on the basis of resource saving and asset accumulation or the generation of borrowing capacity. 


\subsection{Characteristics of growth and its distributive impact}

Some $80 \%$ of household income is derived from employment (waged or own-account). For this reason, labour market determines much of income distribution and the economy's capacity to generate employment and the characteristics of the jobs created are vitally important. ${ }^{11}$

In the region, the creation of jobs, especially waged and formal jobs, is closely associated with economic growth. But since many households need to generate labour income simply to subsist, when economic activity levels are low or falling — and demand for labour is consequently weak - self-employment operates as an adjustment and adaptation mechanism in avoidance of open unemployment (ECLAC and ILO, 2010). Thus, a proportion of employment in the region arises out of labour supply pressure caused by subsistence needs. Comparison between countries tends to reveal a high correlation between demographic change and the variation of the number of employed persons (Weller, 2000, p. 77).

Since the employment rate for the region as a whole reacts strongly to growth pattern changes, Latin America and the Caribbean clearly does not offer an example of "jobless growth". On the contrary, many Latin American and Caribbean countries have in the past evidenced a process of "growthless jobs", in other words, employment creation amid very low growth (Pagés, Pierre and Scarpetta, 2009). These jobs tend to be low-productivity and low-waged jobs and have negative distributive impacts.

When the behaviours of the employment and economic growth rates are analysed in relation to each other, a group of countries emerges with a positive correlation of over 0.5 between changes in the two variables: Argentina, Barbados, the Bolivarian Republic of Venezuela, Brazil, Chile, El Salvador, Mexico, Trinidad and Tobago and Uruguay. On the other hand, the correlation is low in Colombia, the Dominican Republic, Ecuador, Honduras, Jamaica and Peru, and actually negative in the Plurinational State of Bolivia (see figure 15).
Figure 15

LATIN AMERICA AND THE CARIBBEAN (SELECTED COUNTRIES): COEFFICIENT OF CORRELATION BETWEEN ECONOMIC GROWTH AND CHANGES IN THE EMPLOYMENT RATE, 1985-2009

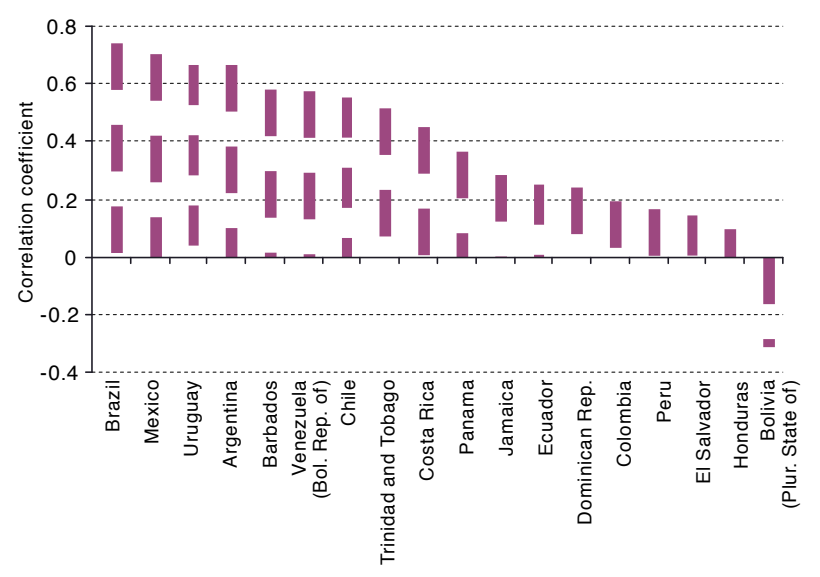

Source: Jurgen Weller, "Contexto macro, empleo e impacto distributivo", document presented in the workshop on distributive impact in public policies, Economic Commission for Latin America and the Caribbean (ECLAC), Santiago, Chile, 28- 29 April 2010.

The fact that the correlation coefficients are higher in countries with higher average incomes, while the countries with lower coefficients are typically those with lower per capita GDP, appears to be consistent with the hypothesis described above. In the second group of countries, the pressure of labour supply is inflexible in relation to the cycle, and subsistence needs force households to generate employment income regardless of variations in demand.

This type of self-generated jobs is characterized by lowproductivity and quality. On the other hand, as mentioned in the previous chapter, countries with relatively high per capita incomes tend to have a more formal labour market, higher levels of social protection and lower rates of poverty and indigence (Uthoff, 2010). ${ }^{12}$

As discussed so far, economic growth and its volatility, as well as demographic change, affect the pressure of labour supply and have a major impact on the generation of employment and on its composition. But other variables, many related to the nature of economic growth, also influence equality outcomes in the labour market. These include the diversity of the productive structure and of the workforce, biases in labour demand by educational level, the quality of employment in terms of social protection, and the possession of attributes which are the object of discrimination (such as gender, religion and country of origin).

\footnotetext{
12 Means of generating resources to fund public policies for improved equality are dealt with in the next chapter.
}

11 For a simple average of 17 Latin American countries in 2005,employment income determined $77.3 \%$ of the Gini coefficient of total income; with the exception of Uruguay, for employment income averaged 0.536 , ranging from 0.452 in Costa Rica to 0.587 in Honduras (Medina and Galván, 2008). 


\section{Distributive aspects of the production structure}

It follows from the discussion in the previous section that the creation of jobs in sectors of widely varying productivity levels has a major impact on income distribution. The employment structure deteriorated during the 1990s and up to the early 2000s (though this was partly reversed in the mid-2000s), with the share of low-productivity sectors in urban employment growing from $47.2 \%$ in 1990 to $50.8 \%$ in 2002 , before falling back to $47.4 \%$ in $2007 .{ }^{13}$

The relative weakness in the creation of productive jobs in the 1990s was also reflected in a widening of the income gap between enterprises of different sizes. The ratio of average wages in microenterprises to those in small, medium-sized and large enterprises fell from $73 \%$ in the early 1990 s to $62 \%$ around 2002 . There was an even greater fall in the incomes of non-technical own-account workers, whose incomes fell from $99 \%$ to $73 \%$ of average wages for small, medium-sized and large businesses. During the following years (data up to 2006), however, when there was an increase in waged job creation jobs in formal enterprises, those gaps narrowed somewhat, to $66 \%$ in the case of microenterprises and to $75 \%$ for own-account workers (ECLAC, 2010b).

As mentioned above, therefore, it may be concluded that because of structural productive heterogeneity, a low-growth phase tends to worsen income distribution, whereas faster growth provides a more favourable context for cutting inequalities. Likewise, it is possible to identity sectoral patterns of job creation which favour or threaten poverty reduction efforts. ${ }^{14}$

\section{The impact on wage inequalities of shifts in the com- position of labour supply and demand}

Wage inequality is partly due to the gap between workers with different skill levels. One notable outcome is that, for comparable occupations, the wage gap between more and less skilled employees has been found to be wider in the poorer countries (Freeman and Oostendorp, 2000). Contrary to the expectations generated by the main schools of economic thought in the 1990s, both national case studies and comparative analyses have shown that, just as in the more developed countries, Latin America and the Caribbean saw a widening of the wage gap. ${ }^{15}$

\footnotetext{
13 Simple average of 15 countries (calculated on the basis of ECLAC (2010b), table 18 of the statistical appendix).

14 Gutierrez and others (2007) found that intensive growth of employment in manufacturing industry fostered poverty reduction, whereas the same trend in agriculture led to increased poverty.

15 See national examples in Robbins (1994), Pavcnik and others (2002), Altimir, Beccaria and González Rosada (2002) and Arabsheibani, Carneiro and Henley (2003); and comparative studies in Behrman, Birdsall and Szekely (2000), IDB (2003) and Contreras and Gallegos (2007).
}

Despite improvements in the educational structure of the workforce, which provided more skilled workers, the incomes of the most highly qualified increased in relation to parts of the workforce with fewer years of formal education. The income gap between those with least schooling and workers with intermediate educational levels has not widened, perhaps because of the strong increase in the supply of labour with secondary education.

There were expectations in Latin America and the Caribbean that economic reforms, especially trade and financial liberalization, as well as the deregulation of labour markets, would promote the use of the most abundant factor, presumably less-skilled workers, thereby increasing their employment and their income. Since the empirical evidence has contradicted that hypothesis, a number of explanations have been offered for the failure of the conventional theory:

- A worldwide technological change tending to favour skilled workers, facilitated by trade liberalization and the growth of foreign direct investment, which has changed the composition of factors in the region's productive structure through imports of capital goods. This caused labour demand to lean towards the higherskilled strata, widening the income gap between different categories of the workforce. ${ }^{16}$

- The comparative advantages of many of the countries of the region are based not on abundant unskilled labour, as had been suggested, but on their natural-resource assets (de Ferranti and others, 2002).

- Massive competition on world markets from countries with large reserves of unskilled, low-waged labour put global pressure on the wages of workers in this category (Freeman, 2005a).

- It has also been argued that macroeconomic policies, particularly exchange-rate and monetary policies, have - sometimes worked unfavourably on relative prices, by raising the cost of labour in relation to capital (Lora and Olivera, 1998; Ramírez and Núnez, 2000). Since capital and skilled labour are usually complementary factors, as long as capital and unskilled labour can substitute each other, these policies would have a regressive impact on distribution.

- Institutional factors such as a falling or stagnant real minimal wage and the weakening of trade unions may also have been important (Cortéz, 2001).

In recent years the widening of the wage gap appears to have stopped, and indeed to have reversed itself partial-

\footnotetext{
16 See Robbins (1996), Feenstra and Hanson (1997), Sánchez-Páramo and Schady (2003) and Jaumotte, Lall and Papageorgiou (2008).
} 
ly. The relative incomes of workers with the most schooling have fallen in relation to those of the most unskilled, but have not returned to the levels of the early 1990s. It should also be noted that — with very small variations during both phases - between the early 1990s and 2006 2008, the gap between the least skilled and the group with nine to twelve years' schooling narrowed (with the coefficient rising from $68.1 \%$ to $72.6 \%$ for waged workers and from $54.7 \%$ to $70.0 \%$ for all employed persons) (ECLAC, 2010b). In light of developments with respect to education, one interpretation for this is that the increase in the supply of labour with intermediate and, in the 2000s, higher educational credentials has had a hand in reducing those groups' relative income. ${ }^{17}$

\section{Macroeconomic volatility and the quality of employment}

The greater or lesser availability of quality jobs (defined as fulltime jobs, without a predetermined end date, and with some degree of social protection) is partly determined by the level and volatility of economic growth.

As mentioned above, between the mid-1990s and the early 2000s, when the unemployment rate rose with each crisis but failed to fall to its pre-crisis level during boom periods, workers displaced from the formal system resorted increasingly to informality and precarious and self-generated employment. In addition, labour reforms in some countries facilitated the use of fixed-term employment contracts, creating additional flexibility at the periphery which caused increased instability and insecurity in formal employment.

On the other hand, the experience of recent years demonstrates how important a favourable economic situation is in underpinning a process of improvement in employment quality. Together with falls in unemployment and in the proportion of jobs in low-productivity sectors, there was an increase in the percentage of the urban population enjoying some level of social protection.

Between 2000 and 2007, the percentage of the urban employed with pension or health protection, or both, rose from $54.5 \%$ to $60.8 \%$ (weighted average) (ILO 2009, table 8-A). As well as economic growth and rising formal-sector employment, this was partly due to a fall in informal employment by formal businesses during that period of relatively high growth. ${ }^{18}$ In a number of countries, more stringent inspection practices played a significant part in this. ${ }^{19}$

\footnotetext{
17 Monsueto, Machado and Golgher (2006), as well as Castro Lugo and Huesca Reynoso (2007) and Airola and Juhn (2008) reported for Brazil and Mexico, respectively, recent reductions in wage inequality by educational level.

18 Between 2005 and 2007, taking an average of five countries, informal wage employment in the formal sector fell from $36.9 \%$ to $31.6 \%$ (ILO, 2008).

19 For the case of Brazil see Simão (2009).
}

\section{Inequalities reflecting patterns of labour market participation by disadvantaged groups}

Lastly, some specific groups encounter particular problems in the labour market. On the one hand, there are constraints on labour-market access — on both supply and demand sides - for women, for example, particularly those with little schooling. On the other hand, horizontal and vertical occupational segmentation and wage discrimination lead to workers with similar characteristics - except for the trait that occasions the discriminationreceiving unequal benefits. Gender and ethnic origin are the main grounds for discrimination.

Analysis of the statistics shows that the participation rate of women living in urban areas rose significantly in the 1990s, but has increased only slightly in recent years. Much of the rise was due to improved educational levels among the female workforce; this improved their labourmarket integration, owing to the strong correlation between women's educational levels and their labour-market participation. On the other hand, participation by women with fewer years of schooling increased only moderately, and has recently slowed (ECLAC, 2010b).

The female urban unemployment rate has reflected economic trends in the region, rising sharply between 1990 and around 2003, then dropping back to a level comparable to that of the early 1990s. The unemployment gap between men and women widened during both periods.

As in the case of unemployment, women's employment in low productivity sectors reflected developments in the region's economy, rising in the early 1990s and subsequently

falling. Here, the gender gap narrowed during the first phase, perhaps as a result of sociocultural pressure on many men (as, traditionally, the principal breadwinners in the household) to accept any employment they could find, even in very low-productivity sectors.

The income gap between men and women narrowed in the 1990s (both for wage earners and for the broader employed population), both overall and for each of the three educational groups. In the 2000s, however, the gap has narrowed very slightly at the aggregate level while widening in some educational groups (ECLAC, 2010b).

In sum, although some of the gender gaps in the labour market have narrowed, access to that market and to productive employment is still highly unequal for the two sexes. This inequality is partly due to sociocultural factors which attribute to women a specific role centred on reproduction and unpaid domestic work, and also to differential access to assets (especially human capital) and to labour-market institutions designed according to the traditional model of the male breadwinner. 
Other discrimination mechanisms persist in labour markets. Studies indicate that there is still wage discrimination against members of ethnic minorities; ${ }^{20}$ they have also identified a wage gap based on workers' socio-economic origin. ${ }^{21}$

\section{SOCIAL SPENDING AND THE BUSINESS CYCLE IN LATIN AMERICA}

Public spending on education, health care social security and housing has major impacts in Latin America, especially owing to the lacks of a significant proportion of the population in these areas. The work of Bello and Ruiz de Castillo (2010) looks at the short- and longterm relationship between social spending and levels of economic activity for a number of countries in the region. Much literature has looked at the relationship between aggregate public spending and GDP both over the business cycle and from a trend perspective, and the main conclusion has been that fiscal policy is procyclical, contrary to the situation case in the countries of the Organisation for Economic Co-operation and Development (OECD).

To estimate the output elasticity of various items of fiscal spending, this work uses annual frequency series for the period 1980-2006, for various components of GDP, public spending, and public social spending, valued in dollars at 2000 prices, for 11 Latin American countries: Argentina, the Bolivarian Republic of Venezuela, Chile, Colombia, the Dominican Republic, Ecuador, Mexico, Panama, Paraguay, Peru and Uruguay.

The main findings are derived from two estimates, the first of which arises from the following equation: ${ }^{a}$

$$
\text { (1) } \begin{aligned}
\Delta \log \left(S S_{i t}\right)=\alpha+\beta * \Delta \log \\
\left(G D P_{t}\right)+\varepsilon_{t}
\end{aligned}
$$

Where: $\mathrm{SS}_{\text {it }}$ : level of spending of the $i$-th component of social spending for the period " $\mathrm{t}$ "

GDP $_{t}$ : level of the country's gross domestic product in the period " $\mathrm{t}$ "

The estimated coefficient, $\beta$, is the shortterm output elasticity of the corresponding spending component. The results show that health-care and education spending were procyclical for eight countries, in seven of them simultaneously, and in all eight both social spending and total public spending were procyclical. Housing expenditure was procyclical in five countries. In Argentina all areas of spending were procyclical; in Colombia and Mexico five areas were. In Chile and Ecuador, however, public spending was acyclical.

To determine whether short-term analysis produces a biased estimate of $\beta$ by failing to consider a long-term relationship between the variables, the authors made a new estimate based on the conditional error correction model. The new estimated equation is:

(2) $\Delta \log \left(S S_{i t}\right)=\alpha+\beta * \Delta \log \left(G D P_{t}\right)+$ $\gamma^{*} \log \left(S S_{i t}\right)-\varphi * \log (G D P)+\varepsilon_{t}$ Where: $\varphi$ is equal to $\gamma^{*} \delta$,

$\gamma$ represents the speed of adjustment of elasticity at its long-term value

$\delta$ is the long-term elasticity of the expenditure component
The main results for the estimated coefficient of the speed of adjustment, long-term elasticity and short-term elasticity are as follows:

- When the coefficient $(\gamma)$ is statistically significant, it is negative and less than unity. This indicates dynamic stability, so that there is a long-term relationship between the variables. For all the countries, at least one of the types of spending has a long-term relationship with GDP. For the Bolivarian Republic of Venezuela, Chile, Colombia, Panama and Uruguay, GDP is cointegrated with five types of spending, whereas for the Dominican Republic, Ecuador and Peru that longterm relationship exists for only one expenditure item. In these cases, equation (2) must be used instead of (1) in order to obtain a proper specification of shortterm elasticity.

- In equations whose dependent variable is education spending, elasticities are greater than unity. Something similar occurs in cases where the dependent variable is health-care spending This implies that in the long term, these items of spending grow faster than GDP.

- Lastly, in the case of Chile, elasticities are not statistically different from zero for any of the social spending variables, which indicates that social spending behaves acyclically.

Source: Omar Bello and Ramiro Ruiz del Castillo, "Gasto social en América Latina: relación con el ciclo y opciones para reducir la volatilidad económica", document presented in the workshop on distributive impact in public policies, Santiago, Chile, Economic Commission for Latin America and the Caribbean (ECLAC), 28- 29 April 2010.

The Phillips and Perron unit root test was performed for the variables expressed in logarithms. All the variables but one (the health-spending logarithm for Peru) were found to be integrated of order one.

20 Atal, Ñopo and Winder (2009) report that the wage gap between persons belonging to ethnic groups which have difficulties with labour-market integration and the rest of the population is $37.8 \%$. If observable variables affecting relative wages are taken into account, that gap falls to $12.9 \%$, showing that a large part of the gap is due to problems with access to productive employment that are related to factors external to the labour market.

21 See Núñez and Gutiérrez (2004) and Gaviria, Medina and Palau (2007). 


\section{The distributive impact of public policy and financing}

\begin{abstract}
The levels of inequality found in the countries of the Latin American and Caribbean region make State action through distributive policies especially important. Public provision of goods and services can change income distribution through programmes whose beneficiaries do not bear the burden of financing (or bear it only in part) and whose impact depends on the level and quality of social spending. But in societies as unequal as those of Latin America, redistributive policy based on public spending is not enough. It is important to examine how this provision is financed and how tax systems work to achieve more equitable income distribution. Not only must a certain amount of resources be generated to finance public spending (especially social spending). It is also necessary to consider which segments of the population are providing those funds.
\end{abstract}

Terms such as "equitable distribution of income", "equal opportunities" and "universal entitlement to economic, social and cultural rights" have long — and legitimatelybeen expressions that shape public and fiscal policy discourse (Basombrío, 2009). But the quest for greater equity is not without ambiguity. As seen in ECLAC (2010b), equity and equality are multi-dimensional, value-laden concepts. Examining their reach can provide an understanding of how they are related to fiscal policy.

Implementing the principle of equity in public sector actions poses special difficulties because of the need to provide conceptual content for the notions of equal and unequal treatment and circumstances and to assess how much the fiscal system is expected to contribute to the attainment of certain redistributive goals. Beyond conceptual debates, though, what is needed is a pragmatic, operative position in the quest for a more just society that will address the most glaring, troublesome inequalities.

The principle of tax equity is rooted in two basic ideas employed to justify the collection and distribution of taxes. One is benefit, which concerns the need to establish taxes on the basis of the benefits that individuals receive from the State. The other is payment capacity, which focuses on the economic capacity of taxpayers and can be used to justify applying progressive criteria (J.P. Jiménez and RuizHuerta, 2009). Equitable distribution of the tax burden among the members of society requires weighing the different circumstances of each taxpayer and gives rise to the criteria of horizontal equity (equal treatment for those in equal circumstances) and vertical equity (appropriately unequal treatment for those in differing circumstances).

This chapter focuses on three elements that are essential to developing a tax policy that improves equity in the countries of Latin America: level of revenue, tax struc- ture and degree of compliance. Unfortunately, the vast majority of countries in the region suffer from significant weaknesses in each of these key areas. The tax burden is low, the tax structure is biased towards regressive taxes and there are significant levels of non-compliance (J.P. Jiménez, Gómez Sabaini and Podestá, 2010).

In taxation, there are no absolute rules for achieving greater equity, and some criteria are ambiguous in that they can work both for and against equity in tax systems at the same time. So, as noted by Musgrave and Musgrave (1992), "Tax policy is an art no less than a science; and equity is to be sought as a matter of degree rather than as an absolute norm".

\subsection{Taxation as a distributive policy tool}

The ability of fiscal policy to modify the distribution of income determined by market forces has changed over time and differs markedly among regions. Studies have shown that the levels of inequality prior to State intervention in countries of Latin America are similar to those in other, more developed countries and that inequality is often greater in the latter (Barreix, Roca and Villela, 2006; Gómez Sabaini, 2006).

But, as emerges from a study by Chu, Davoodi and Gupta (2000), while taxes and spending effectively improve distribution in the industrialized countries, developing countries lack appropriate distributive policies for attaining a comparable degree of equality. Indeed, studies available in Latin America and the Caribbean show that the tax system usually has a regressive effect and that spending programmes only partially offset tax regressiveness. There are even cases in which taxes and transfers not only do not correct inequality - they exacerbate it.

There are two ways in which tax policy can influence a country's income distribution structure. First, it can capture resources to finance public spending aimed at creating and strengthening human capital through health care, education and sanitation programmes, among others. Tax policy thus becomes a factor that contributes to the formation of human capital. By improving market income, it improves "primary distribution", that is, the distribution of income before resources are taxed and transferred. Second, tax policy can act on the income distribution structure through progressive taxes geared to modify "secondary distribution", i.e., the distribution of income after taxes. Income and property taxes, among others, play a key role in this regard (Gómez Sabaini, 2006). 
The three main factors that limit the redistributive role of the State in Latin America are a low tax burden, regressive taxation and poorly targeted public spending (Goñi, López and Servén, 2008). There is disagreement, however, as to whether these factors should be modified. There is broad consensus regarding the need to step up efforts to ensure greater progressivity in public spending. As for the need to increase the tax burden, however, agreement is substantial but more limited. Support for more progressive reforms is weaker.

Experts clearly disagree on taxation's potential as a redistributive tool. Nevertheless, the persistence of this regressive tax structure over the years reveals that the dominant view — at least among those experts in a position to influence tax policy- is that redistribution can be achieved most effectively through social spending, while tax policy should focus on efficiency (Jorratt, 2009).

The magnitude of inequality in Latin America and the Caribbean is such that the potential of taxation as a redistributive tool should not be ignored. It is thus useful to examine why income tax collection levels are so low in the region. Among the main reasons are low legal rates (and even lower effective rates) and narrow tax bases. These and other particularities are related to high tax evasion, as do the tax privileges and loopholes that characterize tax systems in the region. In such an environment, the basic prerequisites of equity — namely, that those with the same payment capacity pay the same (horizontal equity) and those with greater payment capacity pay more (vertical equity) — go unfulfilled.

Equity, both horizontal and vertical, faces significant practical challenges in the countries of Latin America. This compromises the legitimacy of the region's tax systems and ultimately affects their ability to collect revenue. Thus, the countries of the region find themselves trapped in a vicious circle of regressive taxation and scant resources, unequal distribution of income and delegitimization of public institutions and of the role of the State (Gómez Sabaini and O'Farrell, 2009).

Direct taxation must therefore be strengthened, and the balance between direct and indirect taxation must be improved. As noted by Jorratt (2009) in his study of taxation in Chile, if the redistributive impact of the tax system is to be increased, income and property taxes must be redesigned to ensure that they account for a greater share of overall revenue. They must also be made more progressive. He also points out that curbing tax evasion and avoidance is essential, as these practices are among the chief causes of inequity.

Along the same lines, Roca (2009) points out that, while personal income taxes may be designed to produce a given redistributive effect, they will not actually achieve their objective if evasion significantly reduces revenue. As for tax rates, he notes the dichotomy surrounding corporate income tax in most Latin American countries: though nominal tax rates are high $(28 \%$ on average in 2006), effective rates are significantly lower, due to a variety of tax benefits. Thus, fewer resources are available for progressive social spending; horizontal inequity increases, and opportunities for evasion and avoidance multiply.

\section{Level of revenue}

Several studies have shown that the region's potential level of tax revenue is significantly higher than its effective level (Perry et al., 2006; Agosin, Barreix and Machado, 2005). There is thus room for improving the redistributive capacity of the State by providing more revenue. However, as noted by Musgrave and Musgrave, (1992), "a high, moderately progressive tax burden can have a greater impact on the distribution of income than a low, strongly progressive one".

Differences between the countries of the region notwithstanding, their tax burden is generally low, both compared with countries in other regions and relative to their own level of development. More developed countries generally have a larger public sector and thus a higher tax burden. Figure 16 compares 121 countries, using a crosssection regression analysis that focuses on the relationship between tax burden and the per-capita GDP logarithm. ${ }^{22}$

Only four of the nineteen Latin American countries studied are above the regression line. The tax burden in Argentina, Brazil, Nicaragua and the Plurinational State of Bolivia may be described as high in comparison with their per-capita GDP. Costa Rica and Uruguay are very close to the regression line, that is, their tax burden would appear to be adequate in relation to their level of development. The tax burden of the remaining 13 countries is clearly lower than it should be according to their level of development.

This simple exercise shows that most of the countries could increase their tax burden. In aggregate terms, given the level of economic development of the region, the tax burden could be increased by an average of three points of GDP. However, excluding the four countries whose effective tax burden exceeds the potential tax burden brings the average up to five points of GDP.

\footnotetext{
22 It should be noted that this simple exercise is not intended as an analysis of the factors that determine the tax burden in each country. In order to develop such a model, other important variables would have to be examined.
} 
Figure 16

COMPARISON OF TAX BURDEN AND PER CAPITA GDP IN PURCHASING POWER PARITY

(Percentage of GDP and logarithms)

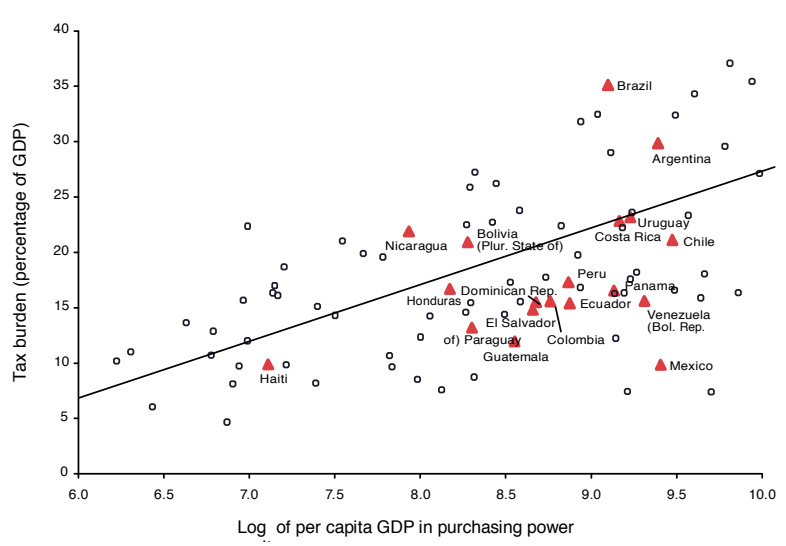

Source: J.C. Gómez Sabaini, J.P. Jiménez and A. Podestá, "Tributación, evasión y equidad en América Latina", Evasión y equidad en América Latina, Projec document No. 309 (LC/W.309), J.C. Gómez Sabaini, J.P. Jiménez and A. Podestá (comps.), Santiago, Chile, Economic Commission for Latin America and the Caribbean (ECLAC), 2010.

The average gap between potential and effective tax burden hides significant differences between countries. The Bolivarian Republic of Venezuela, Ecuador, Guatemala, Mexico and Panama could increase their tax burden to make it more consistent with their GDP per capita. With the exception of Guatemala, these countries generate significant revenues from non-tax sources (oil or the Panama Canal, for example) that partially offset their low tax collections.

Another simple way of demonstrating the low tax burden in Latin America is to compare it with tax burdens in other regions around the world. Figure 17 shows that the average tax burden of Latin American countries is virtually half that of the member countries of the Organisation for Economic Co-operation and Development (OECD).

Figure 17

INTERNATIONAL COMPARISON OF THE LEVEL AND STRUCTURE OF THE TAX BURDEN (Percentage of $G D P)$

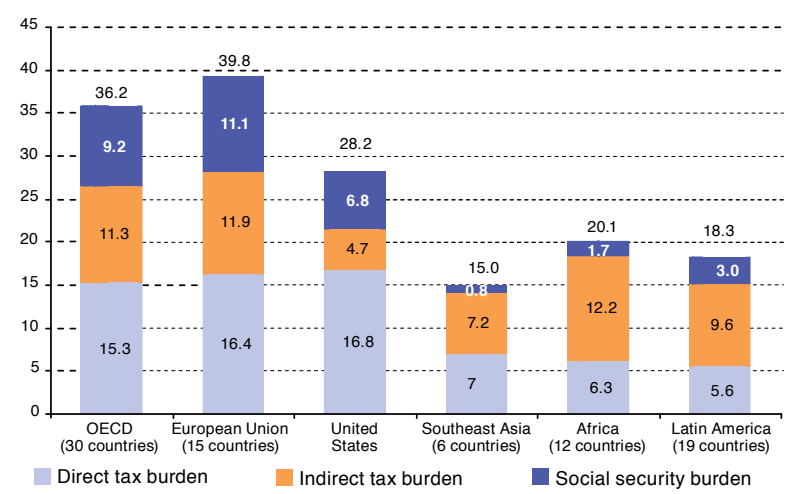

Source: Economic Commission for Latin America and the Caribbean (ECLAC), on the basis of information from Organisation for Economic Co-operation and Development (OECD) and the International Monetary Fund (IMF).

Note: The average for Latin America refers to the central government, except for Argentina, Brazil, Chile, Costa Rica and the Plurinational State of Bolivia, where it refers to the general government.
However, the graph also clearly shows that the region's low tax burden is primarily a result of low direct tax collection (income and property taxes) in terms of GDP. On average, the direct tax burden in developed countries is ten GDP points above that of Latin America. Moreover, revenue from income and property taxes (in relation to GDP) in Latin America is the lowest in the world. Even African countries generate higher revenues from such taxes, on average, than do Latin American countries.

Another significant difference in relation to developed countries lies in lower social security revenues, while taxes on goods and services in Latin America are comparable to those in OECD countries.

As mentioned earlier, one way of improving the distribution of income is through the level of tax revenues that can be earmarked to finance social spending. It is telling that the three countries with the highest tax revenues (Argentina, Brazil and Uruguay) are also those with the highest level of social spending (J.P. Jiménez, Gómez Sabaini and Podestá, 2010).

However, the tax burden is not the only factor that influences the distribution of income in a country. The composition of the tax burden is also important. In other words, it is not simply a question of how much revenue is collected, but also how it is collected. This issue is discussed in the following subsection.

\section{Tax structure}

The second factor to be examined is the origin of tax revenues, bearing in mind the criteria of equity. Studies by Perry et al. (2006), Agosin et al. (2004) and Gómez Sabaini (2006) have noted that the main cause of the gap between potential and effective revenue is a shortfall in direct taxation - more specifically, personal income tax. Virtually no such gap exists with regard to consumption taxes in most of the countries in the region.

Figure 18 illustrates the evolution of the region's average tax structure, which is characterized by the following:

- Declining international trade taxes as a percentage of total revenue. This change was brought about by the creation of economic unions (free trade zones, MERCOSUR), falling nominal import tariffs and the lifting of export taxes (Argentina is the most noteworthy exception to this latter trend).

- Sustained growth in value-added taxes (VAT) throughout the region. Brazil adopted this tax in 1967 and Argentina and Ecuador implemented it in the 1970s, but not until more recently did it expand throughout 
the region and become a strategically important source of revenue.

- Significant growth in income tax revenues. However, income tax focuses on corporations, and this growth is associated with an increase in revenue from mining and oil companies. The greater potential for transferring makes the distributive impact of corporate income tax lower than with personal income tax.

- Personal income tax is essentially a tax on income from formal waged employment.

- Significant decrease in the number of taxes applied, especially selective taxes that now fall only on goods and services with a relatively inelastic demand (such as tobacco, alcoholic beverages and fuel).

- Appearance of extraordinary tax schemes applying to, for example, bank withdrawals and deposits, financial transaction taxes and the like.

- Unresolved issues, both in designing regulations and in administering the tax system, caused by growing market informality during the 1990s, especially in the labour market and in self-generated employment.

- Low, stagnant property taxes despite the existence of a wide variety of taxes that target property in some way. ${ }^{23}$ One of the unresolved challenges in the region has to do with strengthening such taxes, mainly at the subnational government level. Improving cadastral records is essential for ensuring property tax equity and efficiency.

Figure 18

LATIN AMERICA AND THE CARIBBEAN (SIMPLE AVERAGE): TAX STRUCTURE, 1990-2008 (Percentage of GDP)

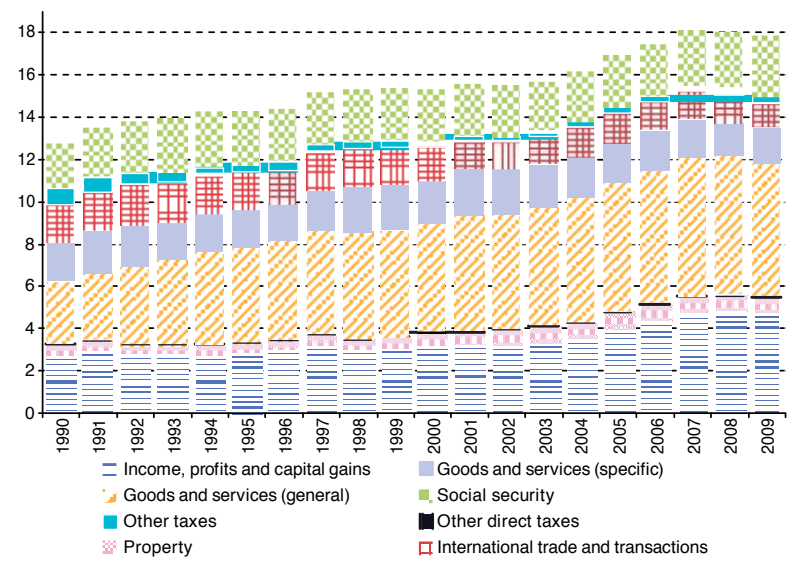

Source: Economic Commission for Latin America and the Caribbean (ECLAC).

23 See the detailed study of property taxes in Latin America, in De Cesare and Lazo Marín (2008).
Income tax revenue grew by more than $70 \%$ across the region between 1990 and 2008, rising from 2.8 to 4.8 points of GDP, on average, during that period. As mentioned above, however, this figure is very low by international standards and is not enough to improve income distribution in the region.

The low relative importance of income taxes is apparent in almost every country in the region. Only the Bolivarian Republic of Venezuela, Brazil, Chile and Peru succeeded in generating income tax revenue equivalent to 6 to 8 points of GDP in 2008. Income tax revenue in Argentina, Colombia, Mexico and Nicaragua is also above the regional average, hovering at approximately $5 \%$ of GDP. As explained earlier, income tax revenue is primarily from income earned by corporations engaged in productive activities related to the exploitation of nonrenewable natural resources.

Figure 19

LATIN AMERICA: CORPORATE AND INDIVIDUAL INCOME TAX (Percentage of GDP)

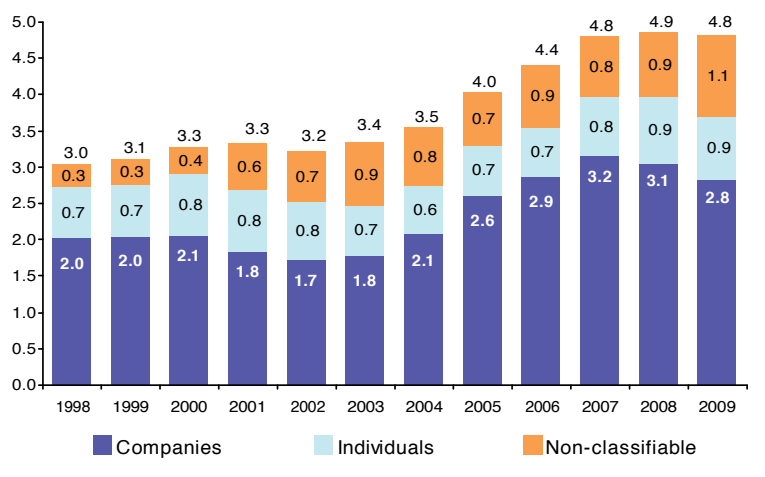

Source: Economic Commission for Latin America and the Caribbean (ECLAC).

Note: "Non-classifiable" corresponds to data where official figures are not broken down between individuals and companies.

As shown in table II.1, Latin America is close to the average for developed countries in terms of corporate income tax (3.4 versus 3.9 points of GDP, respectively). With regard to personal income tax, however, it lags far behind OECD countries. Latin American countries generate only $1.5 \%$ of GDP, on average, from personal income taxes (even in Brazil, the country with the highest percentage, it is only 2.6 percentage points), compared with OECD economies, where it is more than 9 percentage points of GDP. Moreover, most personal income tax revenue in the region is obtained from wage earners, mainly because self-employed persons have greater access to evasion and avoidance strategies and because of the preferential tax treatment accorded to capital income in most countries.

The structure in Latin American countries is therefore the inverse of the structure in OECD countries. In the former, corporate income tax collections account for 
$70 \%$ - the same percentage that in OECD countries is from individual income tax. ${ }^{24}$

In short, the structure of the region's tax systems is one of the factors behind the region's on-going disparities in income distribution. Reforms in this area must therefore focus on increasing the impact of tax policy on income distribution, raising the tax burden on wealthier sectors of society. This can be accomplished, for example, through personal income taxes.

Table II.1

LATIN AMERICA: AVERAGE INCOME TAX COLLECTIONS

(Percentages of GDP)

\begin{tabular}{lccccc}
\hline Country & Companies & Individuals & Total & $\begin{array}{c}\text { Companies/ } \\
\text { individuals }\end{array}$ & $\begin{array}{c}\text { Income/ } \\
\text { consumption }\end{array}$ \\
\hline Argentina (2007) & 3.6 & 1.6 & 5.4 & 2.3 & 0.4 \\
Bolivia (Plurinational State of) (2007) & 3.0 & 0.2 & 3.3 & 14.4 & 0.3 \\
Brazil (2007) & 5.1 & 2.6 & 7.7 & 2.0 & 0.5 \\
Chile (2007) & 7.3 & 1.2 & 8.4 & 6.3 & 0.9 \\
Dominican Republic (2002) & 1.3 & 1.8 & 3.1 & 0.7 & 0.4 \\
Ecuador (2006) & 2.3 & 0.8 & 3.1 & 3.1 & 0.5 \\
El Salvador (2007) & 2.7 & 1.9 & 4.6 & 1.4 & 0.6 \\
Guatemala (2007) & 2.9 & 0.3 & 3.4 & 8.5 & 0.5 \\
Honduras (2004) & 3.7 & 1.6 & 5.3 & 2.3 & 0.5 \\
Haiti (2006) & 1.0 & 1.1 & 2.1 & 0.9 & 0.6 \\
Mexico (2005) & 2.4 & 2.2 & 4.6 & 1.1 & 1.2 \\
Nicaragua (2001) & 3.1 & 2.0 & 5.1 & 1.6 & 0.5 \\
Panama (2006) & 2.9 & 2.0 & 5.0 & 1.5 & 1.8 \\
Peru(2007) & 5.9 & 1.4 & 7.2 & 4.2 & 1.0 \\
Latin America (14) & 3.4 & 1.5 & 4.9 & 2.3 & 0.7 \\
OECD (2006) & 3.9 & 9.2 & 13.0 & 0.4 & 1.2 \\
United States (2006) & 3.3 & 10.2 & 13.5 & 0.3 & 2.9 \\
\hline
\end{tabular}

Source: Economic Commission for Latin America and the Caribbean (ECLAC), on the basis of J. Roca, "Tributación directa en Ecuador. Evasión, equidad y desafíos de diseño", Macroeconomía del desarrollo series, No. 85 (LC/L.3057-P), Santiago, Chile, Economic Commission for Latin America and the Caribbean (ECLAC), 2009. United Nations publication, Sales No. S.09.II.G.55 for Ecuador; M. Cabrera, "La tributación directa en América Latina, equidad y desafíos: el caso de El Salvador", Macroeconomía del desarrollo series, No. 87 (LC/L.3066-P), Santiago, Chile, Economic Commission for Latin America and the Caribbean (ECLAC), 2009. United Nations publication, Sales No. S.09.II.G.60, for El Salvador and Guatemala; D. Álvarez Estrada, "Tributación directa en América Latina, equidad y desafíos. Estudio del caso de México", Macroeconomía del desarrollo series, No. 91 (LC/L.3093-P), Santiago, Chile, Economic Commission for Latin America and the Caribbean (ECLAC), 2009. United Nations publication, Sales No. S.09.II.G.77, for Mexico; and O. Cetrángolo and J. Gómez Sabaini "La tributación directa en América Latina y los desafíos a la imposición sobre la renta", Macroeconomía del desarrollo series, No. 60 (LC/L.2838-P), Santiago, Chile, Economic Commission for Latin America and the Caribbean (ECLAC), 2007. United Nations publication, Sales No. S.07.II.G.159 for Honduras, Nicaragua and Dominican Republic.

24 According to Cetrángolo and Gómez Sabaini (2007), two factors explain why families or individuals account for a larger share of income tax revenue in developed countries than do corporations. First, the tax authorities of those countries have a greater capacity to track large numbers of taxpayers. Second, per capita (or family) income in developed countries is higher, making a larger percentage of the population subject to income tax In Latin America, on the other hand, a large portion of the population falls below the minimum tax threshold. 


\section{Degree of compliance}

Tax compliance is the third factor to bear in mind when examining the distributive impact of tax policy. Without low delinquency and evasion levels, neither the level of revenue nor the tax structure is sustainable. Curbing evasion generates greater resources for social spending. And, as explained above, it is crucial in developing an equitable and progressive tax structure.

Available estimates show that individual and corporate income tax evasion is far deeper than VAT evasion despite the very close relationship between the two taxes (see table II.2). ${ }^{25}$ In recent years, the tax authorities seem to have focused much more on fighting VAT evasion than on evasion related to direct taxes.
ECLAC studies estimate income tax non-compliance at a very high $40 \%$ to $65 \%$. This represents an average gap of $4.6 \%$ of GDP. Such high levels of non-compliance work against the redistributive impact of income tax. Evasion jeopardizes horizontal equity, since evaders pay fewer taxes than taxpayers with the same payment capacity. It also reduces vertical equity, since the incentive to evade becomes stronger as tax rates increase. Moreover, wealthier individuals have greater access to professional advice, which often includes tax avoidance strategies or reduces the risks of non-compliance. Curbing tax evasion and avoidance is therefore essential for improving the distributive impact of tax systems.

Table II.2

LATIN AMERICA: VALUE-ADDED TAX (VAT) AND INCOME TAX NON-COMPLIANCE RATES

(Percentages)

\begin{tabular}{|c|c|c|c|c|}
\hline & \multicolumn{2}{|c|}{ VAT } & \multicolumn{2}{|c|}{ Income tax } \\
\hline & Gap & Estimate year & Gap & Estimate year \\
\hline Argentina & 21.2 & 2006 & 49.7 & 2005 \\
\hline Chile & 10.0 & 2006 & 47.4 & 2003 \\
\hline Dominican Republic & 31.2 & 2006 & $\ldots$ & $\ldots$ \\
\hline Ecuador & 21.2 & 2001 & 63.8 & 2005 \\
\hline El Salvador & 27.8 & 2006 & 45.3 & 2005 \\
\hline Guatemala & 37.5 & 2006 & 63.7 & 2006 \\
\hline Mexico & 20.0 & 2006 & 41.6 & 2004 \\
\hline Nicaragua & 26.0 & 2006 & $\ldots$ & $\ldots$ \\
\hline Panama & 33.8 & 2006 & $\cdots$ & $\cdots$ \\
\hline Peru & $\ldots$ & $\ldots$ & 48.5 & 2006 \\
\hline Uruguay & 26.3 & 2006 & $\ldots$ & $\ldots$ \\
\hline
\end{tabular}

Source: Economic Commission for Latin America and the Caribbean (ECLAC), on the basis of O. Cetrángolo and J.C. Gómez Sabaini "La tributación directa en América Latina y los desafíos a la imposición sobre la renta", Macroeconomía del desarrollo series, No. 60 (LC/L.2838-P), Santiago, Chile, Economic Commission for Latin America and the Caribbean (ECLAC), 2007. United Nations publication, Sales No. S.07.II.G.159; M. Jorratt De Luis, "La tributación directa en Chile: equidad y desafíos", Macroeconomía del desarrollo series, No. 92 (LC/L.3094-P), Santiago, Chile, Economic Commission for Latin America and the Caribbean (ECLAC), 2009. United Nations publication, Sales No. S.09.II.G.78; J. Roca, "Tributación directa en Ecuador. Evasión, equidad y desafíos de diseño", Macroeconomía del desarrollo series, No. 85 (LC/L.3057P) Santiago, Chile, Economic Commission for Latin America and the Caribbean (ECLAC), 2009. United Nations publication. Sales No. S.09.II.G.55; M. Cabrera and V. ( Macroeconomía del desarrollo series, No. 87, (LC/.3066-P), Santiago, Chile, Economic Commission for Latin America and the Caribbean (ECLAC), 2009. United Nations publication, Sales No. S.09.II.G.60; M. Cabrera, "La tributación directa en América Latina, equidad y desafíos: el caso de Guatemala", Macroeconomía del desarrollo series, No. 89 (LC/L.3081-P), Santiago, Chile, Economic Commission for
Latin America and the Caribbean (ECLAC), 2009. United Nations publication, Sales No. S.09.II.G.68; D. Álvarez Estrada, "Tributación directa en América Latina, equidad y desafíos. Estudio del caso de México", Macroeconomía del desarrollo series, No. 91 (LC/L.3093-P), Santiago, Chile, Economic Commission for Latin America and the Caribbean (ECLAC), 2009. United Nations publication, Sales No. S.09.II.G.77; L. Arias Minaya, "La tributación directa en América Latina, equidad y desafíos. El caso de Perú", Macroeconomía del desarrollo series, No. 95 (LC/L.3108-P), Santiago, Chile, Economic Commission for Latin America and the Caribbean (ECLAC), 2009. United Nations publication, Sales No. S.09.II.G.89.

25 This is why the studies compiled by J.P. Jiménez, Gómez Sabaini and Podestá (2010) make a significant effort to estimate the level of income tax non-compliance in seven Latin American countries. Direct taxation has also been thoroughly analyzed, and the main issues that affect distributive equity have been identified.. 
Box II.1

\section{EQUITY IN VALUE-ADDED TAX (VAT) AND IN INCOME TAX}

Tax design is the most direct way in which tax policy affects the distribution of income. Each tax can be progressive, proportional or regressive. Combined, they can have an aggregate redistributive effect. The two basic principles of tax equity are vertical equity (an individual with a higher tax payment capacity should pay proportionally more taxes than one with a lower payment capacity), and horizontal equity (individuals with similar tax payment capacities should be taxed similarly). The study discussed in this box assesses the vertical and horizontal equity of the two main taxes that affect households - value-added tax (VAT) and income tax - in three countries: Ecuador, Guatemala and Paraguay.

The methodology used involves comparing the distribution of household income before and after taxes. The unit of analysis is the household; family income is the variable chosen as the indicator of wellbeing. Equivalence-scale-adjusted per-capita income is used to compare households with different numbers of members. Equivalent income, Ye, is thus defined as

$\mathrm{Ye}=\mathrm{Y} / \mathrm{na}$;

where Y: nominal household income;

$\mathrm{n}$ : number of household members;

a: factor reflecting household economies of scale (given the existence of semi-fixed costs).

To determine the feasibility of improving tax system progressivity and horizontal equity, selected equity indicators were applied to simulated reforms. The outcomes of the reforms were then compared with those of the system in place.

The VAT reforms considered were:

- Repeal exemptions, except those that apply to financial services;

- Transfer the increased revenue from non-exempt VAT to the three poorest deciles.

The simulated income tax reforms were:

- Keep the existing income tax, but repeal the tax expenditures;

- Flat income tax: Replace the personal income tax rate scale with a scale that has two brackets (one that is exempt and one that is subject to a single marginal rate). The corporate income tax rate is also changed. The rate and the exempt bracket are chosen in order to match revenue in exercise (a);

- Dual income tax: keep the existing rate scale for income from waged work, with a single rate for capital income and own-account work. Adjust the flat rate to obtain the same revenue as in the first exercise;

- Family income tax: the unit of taxation is not the individual but the household Maintain the existing rate structure; the basis of assessment is equivalent income Ye;

- These four reforms were then evaluated, assuming that the increased revenue is transferred to the three poorest deciles. These exercises yielded interesting conclusions for the three countries.
Regarding VAT, the noteworthy outcomes were:

- VAT is vertically regressive in the three countries, but transferring revenue to the three poorest deciles improves income distribution compared with the current situation;

- Horizontal equity remained at similar levels in Ecuador and Guatemala and decreased somewhat in Paraguay;

- Broadening the tax base by eliminating exemptions increased both vertical and horizontal inequity.

Some of the key outcomes regarding income tax were:

- Income tax is progressive in the three countries and has a high degree of horizontal inequity, especially in Guatemala and Paraguay:

Broadening the base (repealing tax expenditures) and redistributing the increased revenue would bring the Gini coefficient down by a range of 0.03 points (Ecuador) to 0.06 points (Guatemala);

- The family income tax is the one that achieves the greatest redistributive impact in all three countries, as well as the best horizontal equity performance;

- Repealing tax expenditures is more progressive than the flat- and dual-rate alternatives. But the loss of progressivity with the latter two options is not of a magnitude such that would bar considering them on the basis of their advantages in terms of simplicity and efficiency. 


\section{Distributive impact of social policies}

\subsection{Social policy focus in the region}

\section{Social policy focus and evolution of social spending in Latin America}

\section{The debt crisis of the early 1980s brought significant restrictions in both the magnitude and the composition of social spending in the region. Redefining the role of the public sector in the economy was part of wide-ranging structural reforms, as were, inter alia, trade liberalization, opening the economy up to foreign investment, price deregulation, market deregulation, greater labour market flexibility and privatization of public enterprises (ECLAC, 1998).}

There were two main drivers behind State reform. The first was the need to reformulate the types of intervention as the prevailing model of the State as benefactor faced increased difficulties. The second was the financial restrictions imposed by the crisis. To cover the fiscal deficit, policy was geared to reduce public spending, particularly its social component. This weakened the social role of the State in providing and regulating certain goods and services. In some countries, social spending was cut, and some social services were privatized — pension and health care systems among them. In other cases, they were decentralized and removed from the purview of the central government under schemes that did not always take appropriate sectoral planning criteria or distributive impact into consideration.

In the case of pensions and following a long tradition of pay-as-you-go regimes and inter- and intra- generational solidarity with varying degrees of coverage, it was sought to tie individual benefits more closely to individual contributions. The goal was to buttress the financial solvency of contributory systems, foster broader coverage (by making the contributions seem more like savings and less like taxes) and, no less important, remove from the sphere of public policy the challenge posed by demographic transition, which required ever-increasing rises in contributions to cover the needs of a growing number of pensioners.

As for health care, private insurance (which usually closely links health risks to the contributions a person must make to cover them) was promoted. So, in a departure from tradition, solidarity was not a key organizational principle in this very restrictive approach to public intervention focused on serving the most disadvantaged segments of society. Moreover, the decentralization of education and public health systems was encouraged, with the resulting problems in financing and providing services at the subnational level (as will be seen below). Social policies for reducing poverty emphasized programmes focused on the neediest.

In the late 1990s, these trends slowly began to reverse as the value of public action in the social sphere was reevaluated and solidarity reappeared as an organizational principle. This gave impetus to policies oriented to channelling more resources to the poorest sectors, and the role of social development in fostering productive development and economic growth was acknowledged. It was in this scenario that ECLAC advocated a reformulation of the fiscal covenant that would make the new proposals sustainable (ECLAC, 1998).

The trend since then has clearly been towards increasing social public spending in both absolute and relative terms. But this change in the amount of resources allocated to social policy did not go hand-in-hand with a radical change in guiding principles. It was not until the turn of the century that the idea of the social role of the State began to shift towards a more integrated vision.

During the 2000s, public policy focused more on the universal nature of certain rights, the principle of solidarity in financing, protection in the event of loss of family income and situations of poverty and exclusion. This turning point is in line with the idea of equal rights, not only equal opportunities. It is precisely the universal nature of rights that shifts the approach from one that favours individual capacities and private provision for old age and health risks (relegating solidarity and state provision to a distant second place) towards one that integrates both components (ECLAC, 2006).

In the case of pension systems, the private pillars based on individual savings should be seen as complementing a public solidarity pillar with explicit solidarity features for those who lack sufficient savings capacity, and another, non-contributory pillar for those who do not have access to social security benefits. In turn, health care systems based on individual insurance should be progressively complemented by insurance pools and guarantees of universal coverage. In the fight against poverty, conditional transfer programmes gain predominance, linking cash transfers to certain behaviours, such as school attendance, medical check-ups, vaccinations and booster doses - i.e., human capital improvement. This is based on the idea that, since the strategies used by the poorest to deal with the vagaries of economic activity can lead to negative human capital savings and perpetuate poverty, action that targets both the causes and the consequences of poverty can halt its intergenerational reproduction (Villatoro, 2007).

Nevertheless, despite the change in approach and the upward trend in resources available for social policy, the 
availability of public resources is still severely restricted by persistent low tax burdens, tax collection difficulties and growth volatility.

In this new state of affairs and after five years of successful outcomes in reducing poverty, unemployment and income inequality, the world financial crisis and its impacts have given new meaning to the role of the State as regulator and intervenor in the face of market failures and asymmetries. But this return to certain organizational principals for social policy in the region has come with innovations in both practice and theory that have brought the concepts of social capital, cohesion and security against risk back into the debate. On the practical level, the adoption of information and communication technologies by governments has, for example, made it possible to expand conditional transfer programmes for the neediest households and administer taxes with higher redistributive effects whose complexity was previously considered an obstacle to achieving their goal at a reasonable cost. Conceptually, there is renewed concern about inequality while recognizing the obvious limitations of the contributions that individuals and the market can make to solve such problems. In short, the State acquires greater strategic weight in the quest to address the problems caused by inequality and the lack of well-being.

As the approach to the issue and the policies put in place evolved, social spending rose by more than five percentage points of GDP between 1990 and 2008 and increased significantly as a percentage of total public spending (see figure 20). In absolute terms, social public spending per inhabitant nearly doubled in 2006-

2007 compared with 1990-1991 and reached US\$ 820 (at 2000 prices), i.e., an $18 \%$ increase over 2004-2005. These increases revealed a marked difference between countries —as much as 20 times more in countries with higher percapita spending than in those with lower spending levels.

The largest omcreases were in social security, education and social assistance. Overall, the information available indicates that education, health care and social assistance are the functions thar effectively generate progressive distribution (see figure 21). Specifically, targeted social assistance, primary education and primary health care are progressive. Although higher education and hospital care are progressive with regard to the primary distribution of income, they remain regressive when considered separately (ECLAC, 2010a).
Figure 20
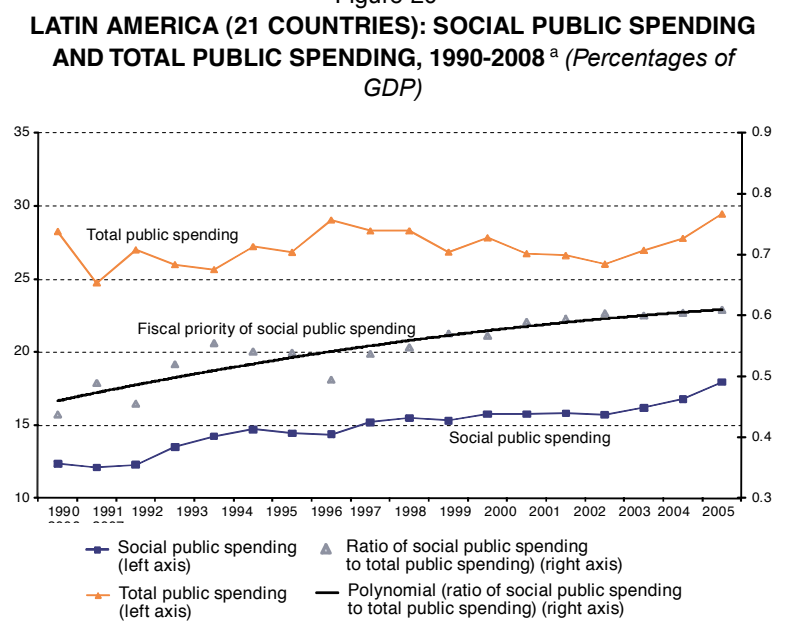

Source: Economic Commission for Latin America and the Caribbean (ECLAC). a Weighted average.

As box I.1 shows, one of the problems with social spending in the region is its highly procyclical nature. This explains the marked impact of crises and growth slowdowns on poverty and vulnerability, because segments with fewer resources needed to address these deficiencies. It was not until the past decade that some countries began to take a countrercyclical approach to social spending, recognizing the role that positive emplyment and household income dynamics play in narrowing gaps and consolidating well-being. Moreover, the current financial crisis and its effects on the real economy have led the governments of the region to redouble and diversify their countercyclical social spending.

But despite these advances, the redistributive content of social spending is still insufficient and should be enhanced in order to narrow even further the gaps in health, education, housing and social conditions in general that lead to the intergenerational transmission of inequality and poverty. The current debate has highlighted three key areas for redistributive policy and for ending the intergenerational transmission of poverty and its conditioning factors, in which social policy is very effective: reducing poverty during childhood and old age, and reducing the effects of unemployment. 
Figure 21

LATIN AMERICA (18 COUNTRIES): DISTRIBUTION OF SOCIAL PUBLIC SPENDING BY PRIMARY INCOME QUINTILE, 1997-2004 (Percentages)
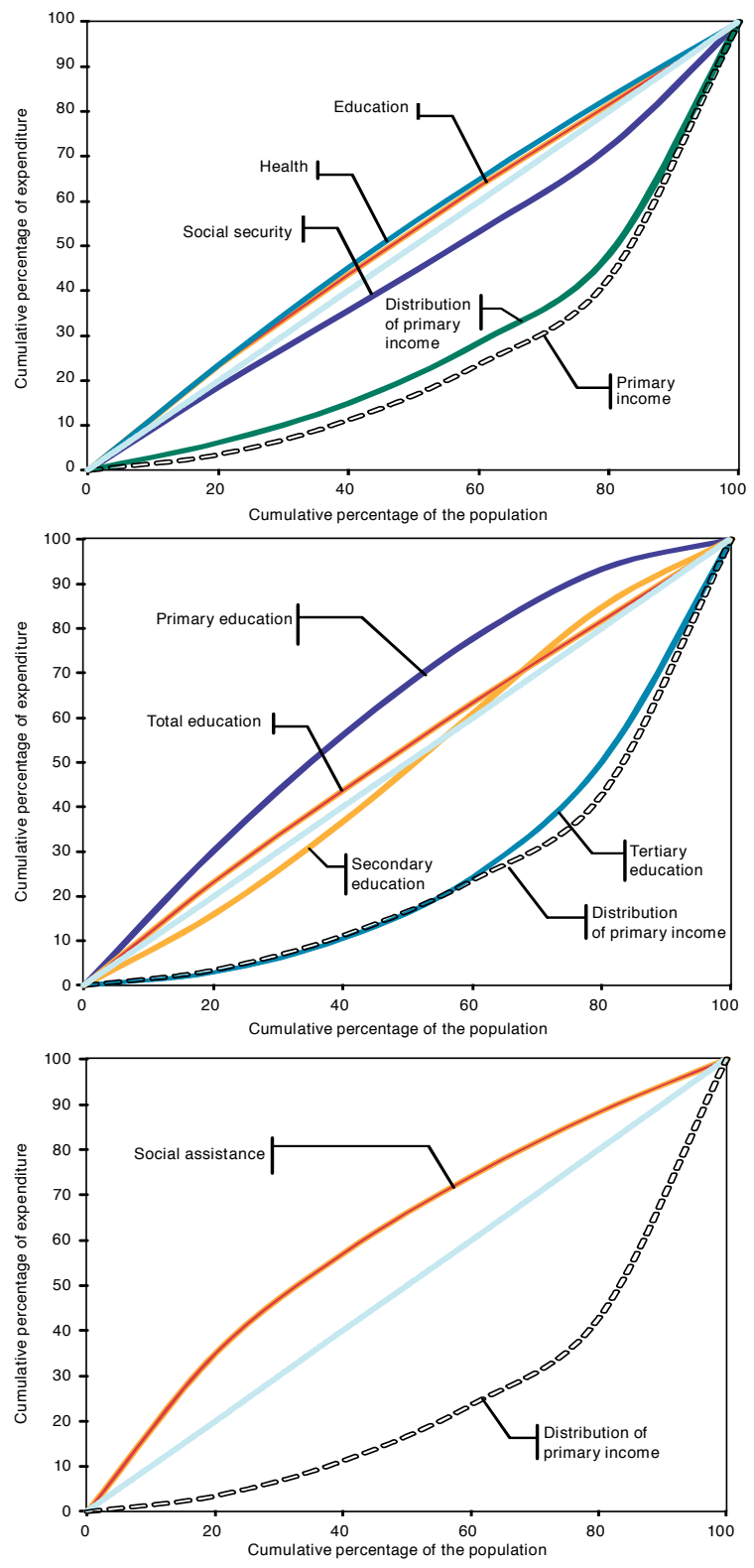

Source: Economic Commission for Latin America and the Caribbean (ECLAC), based on Social Panorama of Latin America 2007 (LC/G.2423-P), Santiago, 2007. United Nations publication, Sales No.: S.07.II.G.124.

\section{Transfers to address childhood poverty and precari-} ous old age and to protect the unemployed

In Latin America, the poverty rate among children is far higher than in the adult population. Measures taken in the past few years to address this situation include cash transfers and reformed family allowance systems that not only seek to ensure a minimum family income but are also conditional on keeping children in school and complying with certain periodic health care protocols (vaccinations, check-ups). 1 These programmes are relevant redistribution instruments geared to level out conditions for children and other vulnerable groups. Between 60\% and $75 \%$ of these transfer expenses are captured by the poorest $40 \%$ of the population (see figure 23). However, spending on such programmes accounts for, on average, only $0.25 \%$ of GDP and $2.3 \%$ of social spending in the region. And they are far from attaining satisfactory coverage.

A recent ECLAC study shows that a cash transfer to children under five years of age equivalent to the value of one poverty line would decrease the number of poor households by a maximum of $7.4 \%$ in Guatemala and a minimum of $2 \%$ in Uruguay and would mean substantial progress at the regional level. For certain more developed countries, this would involve resources equal to $0.8 \%$ to $1.6 \%$ of GDP and would thus be achievable within a very few years. By contrast, in the poorest countries it would mean as much as $6.4 \%$ of GDP annually; this shows the serious challenge that these countries face (ECLAC, 2010b).

At the other end of the age range, despite substantial pension system reform efforts centred mostly on more closely linking contributions and benefits, there are still problems in preventing poverty among the aged. These problems arise from structural limitations associated with the characteristics of the region's labour market: high degree of informality and frequent periods of unemployment; low labour participation rates among poor women; inadequate reach of formal schemes in rural areas; and, perhaps most important, low wages in broad segments of the productive apparatus (ECLAC, 2006; Tokman, 2006; Cetrángulo and Grushka, 2004; Jiménez and Cuadros, 2003). 
Figure 22

LATIN AMERICA (17 COUNTRIES): CHILD POVERTY RATIOS AROUND 1990, 2002 AND 2008; CHILDREN AGED 0-14 COMPARED WITH THOSE OVER 14

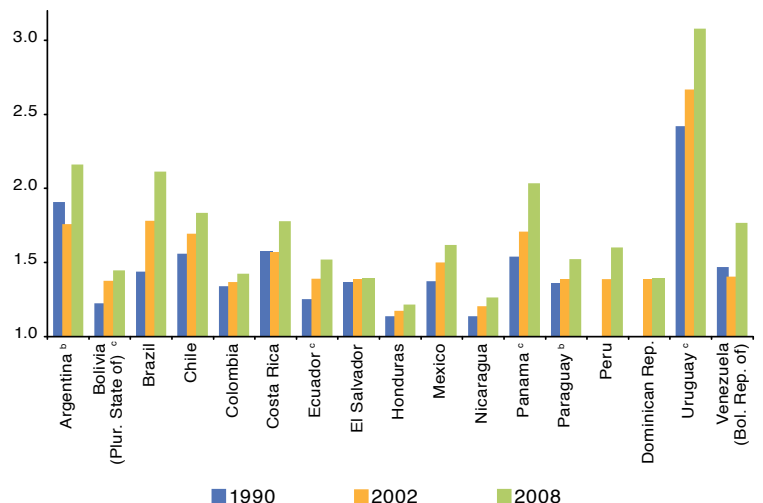

Source: Economic Commission for Latin America and the Caribbean (ECLAC), Time for equality: closing gaps, opening trails (LC/G.2432(SES.33/3)), Santiago, Chile, 2010

The year of the survey used differs from one country to the next. The data for 1990 correspond to the available survey closest to that year. The data for 2002 correspond to the most recent surveys available between 2000 and 2002, and those for 2008 are from surveys available between 2004 and 2008.

Metropolitan area.

Urban area.

Figure 23

LATIN AMERICA (15 COUNTRIES): DISTRIBUTION OF PUBLIC EXPENDITURE ON SOCIAL WELFARE AND EXAMPLES OF DIRECT CASH TRANSFERS UNDER SELECTED CONDITIONAL TRANSFER PROGRAMMES, BY PRIMARY INCOME QUINTILE, 2005-2008 ${ }^{a}$ (Percentages)

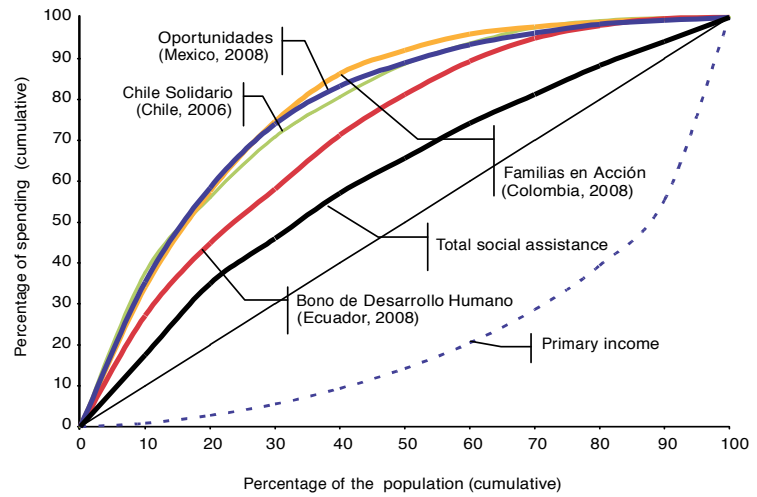

Source: Economic Commission for Latin America and the Caribbean (ECLAC), Time for equality: closing gaps, opening trails (LC/G.2432 (SES.33/3)), Santiago, Chile, 2010.

a Simple average.

These factors together mean that a significant number of persons participating in private systems would not accumulate enough resources to draw a minimum pension, especially in the case of less skilled workers and women. And there is still a need to prevent poverty in old age for large groups that do not participate (due to rurality or informality) but would in the future press for government support for their survival. In response, a new wave of reforms is seeking to create or strengthen a solidarity pillar funded by a pool of contributions while putting new emphasis on non-contributory schemes financed by taxes.
Willmore (2006) analysed what the cost of a universal, uniform pension would be in the countries of the region. ${ }^{26}$ More recently, ECLAC (2010a) estimated the cost of transferring the equivalent of one poverty line to all persons over 65 under a universal scheme or of targeting benefits to members of vulnerable households. With the universal scheme, the cost ranges between $1.8 \%$ and $5.7 \%$ of GDP per annum; for the targeted scheme it varies from $0.3 \%$ to $4.2 \%$ of annual GDP. Again, these figures are more onerous for countries with a higher poverty rate and lower per-capita GDP.

Beyond the difficulty of establishing the order of causality between poverty and unemployment, there is no denying that unemployment has a greater impact on poor households, makes systems of saving for old age less effective and often means the loss of social benefits, such as access to protection from health risks, that often come only with a contractual employment relationship.

To mitigate these consequences, some of the countries of the region have established unemployment insurance that provides compensatory, transitory income while improving prospects for productive reinsertion. But only seven countries in Latin America and the Caribbean have such an instrument. Coverage and benefits are usually limited and apply only to workers in the formal sector —and, among these, to those who have a certain degree of job stability because entitlement to benefits hinges on remaining for a minimum period of time in the job from which contributions to the system are made (Velásquez, 2010). During the recent crisis some of these schemes have been reformulated to make them more countercyclical by, for example, making access to them easier or combining them with training mechanisms. Nevertheless, their dissemination and institutionalization are still limited in most of the countries of the region.

The challenge of improving the efficiency and redistributive effect of unemployment insurance lies in broadening its coverage, linking it more closely to active labour market policies and integrating it with other protection mechanisms such as severance pay and non-contributory systems that provide support for low-income families. In view of the limited coverage provided by unemployment insurance, many countries have emergency employment programmes that are activated, above all, during crises and help cover the income needs of persons in the informal sector or rural areas. An alternative to such a regime could be the creation of non-contributory unemployment insurance systems that would broaden protection; benefits could, perhaps, be conditional on training programmes or other measures geared to improve employability.

26 See details on the relevance of this alternative for poor countries in Willmore (2006). 


\subsection{Social policies in the areas of pensions, health and education}

The impact of social policies on distribution does not depend solely on the initiative involved or how a programme is designed, on the magnitude of the public resources involved or on the coverage of the beneficiary population. It also depends on how they are financed. This section will highlight the distributive impact of social policy financing. The debate on the formulation and financing of social policies entails two key lines of discussion. The first has to do with contributory versus non-contributory financing of social protection. The other involves a necessary stock- taking of the region's experience with decentralization over the past 30 years and the advisability (and feasibility) of ensuring the local origin of that financing as well as the consequences thereof for equity and fiscal consistency.

\section{Pension systems}

In the case of contributory pay-as-you-go pension systems, demographic transition (which invariably increased the number of pensioners with relation to contributors), the failure to adjust contribution rate parameters or eligibility requirements, the presence of sectoral privileges and a voluntaristic definition of replacement rates led to designs that did not ensure the solvency of the system over time. Later came the tensions deriving from globalization, which resulted in certain cases in rising open unemployment rates and the reassignment of the workforce to less productive sectors or self-employment. This helped spur different kinds of reform that, to varying degrees, sought a closer link between contributions and benefits.

Pension system reforms can be classed in two major groups: structural reforms and parametric reforms. The former include the adoption of three alternative models: (i) the pure substitution model, with individual funding being the only option; (ii) the parallel model, which retains a reformed (public) pay-as-you-go regime alongside the individually funded model and allows workers to opt for one or the other; and (iii) the mixed model, in which the worker contributes simultaneously to both systems. In practice, there is no pure model; almost all of the countries have some kind of assistance transfer system for old age or complementary private schemes. Parametric reform, as the name suggests, retains the general profile or basic structure of the pre-existing system but changes the calculation algorithms and the values for strategic variables (contribution rates, legal retirement age and replacement rates, among others).

However, the reforms carried out did not resolve all of the complex problems of the region's pension systems. ${ }^{27}$

27 See details on the relevance of this alternative for poor countries in Willmore (2006).
Unlike what was expected, introducing capitalization components did not lead to an increase in contributory participation or to complete self-funding of benefits for most of those enrolled in these systems. Under such a regime contributions would be more like savings than like taxes, but lower-income groups, tending to prioritize present consumption over future consumption, often remain outside the system. The result is that effective coverage is no broader than under the previous scheme. At the same time, the higher incidence of unemployment and informality in lower-income groups is reflected in their lower contribution density, leading to lower accumulation of savings. And even for those low-income groups that manage to stay active in the new system and attain an adequate contribution density, low income means little accumulation of resources and will likewise make them candidates for subsidies to bring them up to the minimum pensions guaranteed by the State. In short, such systems are not likely to overcome the exclusions that characterize the region's labour market. On the contrary: adding individuallyfunded accounts removed a good deal of the solidarity inherent to pay- as-you go systems, turning employment inequities into welfare inequities (Cuadros and Jiménez, 2004).

As stated above, the region now faces a scenario characterized by marked social segmentation in the labour sphere (formal workers, informal workers and the unemployed) and, therefore, in the area of social protection. Low collections because of growing informality, combined with the demand for additional resources arising from the financial imbalances of pre-existing pay-as-you-go pension systems that are still paying their beneficiaries, have often displaced other social policies geared to channel resources to lower-income sectors. Generally speaking, financial sustainability and fiscal deficit problems remained in those countries that introduced substitute individual funding schemes, because the transition costs were higher and more persistent than expected. ${ }^{28}$ As a result, in some countries a gap is opening between total spending on pensions and the spending that has redistributive effects, as figure 24 shows for Argentina and Chile.

The main lesson to be learned from these reforms is that the reality of the region's labour markets does not allow basing a pension system on the contributory component alone. Because of labour market exclusions and segmentation, this would lead to marked inequalities and undersaving for old age that the State will have to address more sooner than later. The contributory component will have to be reinforced by incorporating solidarity mechanisms in the funding of benefits. This is, in part, the approach taken by recent pension system reforms in the region. Noteworthy among them is the pension reform in Chile discussed in box III.1.

28 See the discussion of the fiscal costs of substitutive reform in Rodríguez Herrera and Durán Valverde (2000). 
Figure 24

ARGENTINA, CHILE AND COLOMBIA: TOTAL AND REDISTRIBUTIVE PENSION SPENDING, 1997-2007

(Percentages of GDP)

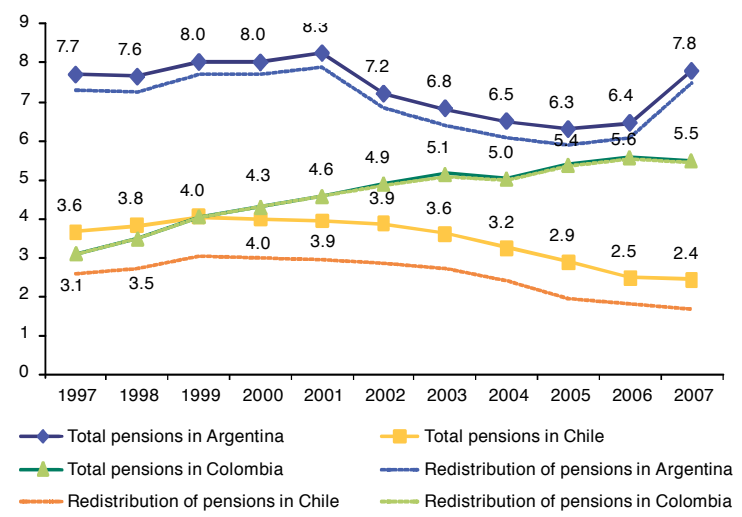

Source: Óscar Cetrángolo, "La seguridad social en América Latina y el Caribe. Una propuesta metodológica para su medición y aplicación a los casos de Argentina, Chile y Colombia", project documents, No. 258 (LCN.258), Santiago, Chile, Economic Commission for Latin America and the Caribbean (ECLAC), 2009.

\begin{tabular}{|c|c|c|}
\hline & $\begin{array}{c}\text { Box III.1 } \\
\text { THE RECENT PENSION REFORM IN CHILE }\end{array}$ & \\
\hline $\begin{array}{l}\text { Up to } 1979 \text {, Chile's contributory pension } \\
\text { system was a public pay-as-you-go system, } \\
\text { with many special regimes. It was replaced } \\
\text { with an individual funding regime based } \\
\text { on compulsory defined contributions } \\
\text { (made by the worker for an equivalent of } \\
\text { up to } 10 \% \text { of wages) managed by pension } \\
\text { fund managers (AFPs) that charge a fee } \\
\text { to cover administrative costs and provide } \\
\text { disability and survival insurance and are } \\
\text { subject to regulation and oversight by the } \\
\text { Superintendency of AFPs. } \\
\text { In addition to creating a new pension } \\
\text { scheme-in which participation was voluntary } \\
\text { for those who had been paying in to the } \\
\text { previous system and compulsory for those }\end{array}$ & $\begin{array}{l}\text { joining the labour force in or after } 1983-\text { the } \\
\text { Institute of Social Security Standardization } \\
\text { was created in the framework of the public } \\
\text { contributory system. It was an independent } \\
\text { agency with its own capital created to manage } \\
\text { the pension systems that had been the } \\
\text { responsibility of the previous pension entities } \\
\text { (Provident Funds), among other functions. } \\
\text { A novel structural reform for improving } \\
\text { the pension system was approved in } 2008 \text {, } \\
\text { and implementation began that same } \\
\text { year. The reform had a broader scope: } \\
\text { add a solidarity pillar by creating a basic } \\
\text { solidarity-based pension and providing a } \\
\text { publicly-funded pension top-up for low- } \\
\text { income pensioners; grant a set benefits }\end{array}$ & $\begin{array}{l}\text { designed to redress the status of women; } \\
\text { create incentives for young persons to pay } \\
\text { in to the system; gradually require own- } \\
\text { account workers to participate; apply new } \\
\text { regulations geared to improve the efficiency } \\
\text { and transparency of the pension fund } \\
\text { administration company industry; redesign } \\
\text { the institutional framework of the pension } \\
\text { system and formulate a funding policy } \\
\text { consistent with fiscal commitments. } \\
\text { This reform is so extensive that it can } \\
\text { be considered structural - not only does } \\
\text { it improve the existing system but it brings } \\
\text { in new components that recognize and } \\
\text { institutionalize the mixed nature of its sources } \\
\text { of funding, as the table below shows. }\end{array}$ \\
\hline
\end{tabular}

\section{CHILE: CHANGES IN THE PENSION SYSTEM}

\begin{tabular}{|c|c|c|c|c|c|}
\hline \multicolumn{2}{|l|}{ Before 1980} & \multicolumn{2}{|c|}{ Substitutive structural reform (1980) } & \multicolumn{2}{|c|}{ Comprehensive structural reform (2008) } \\
\hline $\begin{array}{l}\text { Contributory } \\
\text { regime }\end{array}$ & $\begin{array}{l}\text { Non-contributory } \\
\text { regime }\end{array}$ & $\begin{array}{l}\text { Contributory } \\
\text { regime }\end{array}$ & $\begin{array}{l}\text { Non-contributory } \\
\text { regime }\end{array}$ & $\begin{array}{l}\text { Contributory } \\
\text { regime }\end{array}$ & $\begin{array}{l}\text { Non-contributory } \\
\text { regime }\end{array}$ \\
\hline $\begin{array}{l}\text { Public pay-as-you-go system } \\
\text { and special regimes }\end{array}$ & $\begin{array}{l}\text { Pension assistance } \\
\text { programme (PASIS) }\end{array}$ & $\begin{array}{l}\text { State-guaranteed } \\
\text { privately funded } \\
\text { system, with the } \\
\text { public system } \\
\text { being phased out }\end{array}$ & PASIS & $\begin{array}{l}\text { State-guaranteed } \\
\text { privately-funded } \\
\text { system, with the } \\
\text { public system being } \\
\text { phased out and a } \\
\text { solidarity pillar added }\end{array}$ & $\begin{array}{l}\text { PBS } \\
\text { (basic solidarity } \\
\text { pension) }\end{array}$ \\
\hline
\end{tabular}

Source: M. Velásquez Pinto, "El caso de Chile", La seguridad social en América Latina y el Caribe. Una propuesta metodológica para su medición y aplicación a los casos de Argentina, Chile y Colombia, project documents, No. 258 (LCW.258) O. Cetrángolo (ed.), Santiago, Chile, Economic Commission for Latin America and the Caribbean (ECLAC), 2009.

Some of the principle components of the reform are described below.

(i) Solidarity benefit:This is a publiclyfunded benefit granted to those who are entitled to a pension lower than the maximum pension funded by solidarity contributions. It supplements and is inversely proportional to the self-funded pension that an individual receives. (ii) Child bonus: All women over 65 who begin to draw a pension on or after 1 July 2009 will receive a bonus for each live-born child, equal to 12 months of social security contributions based on $10 \%$ of the minimum wage, funded in accordance with the return on pension fund $\mathrm{C}$.

(iii) Greater coverage for young workers: Two tax-funded contributions will be paid: a hiring subsidy for employers who hire young workers (age 18 to 35 who receive up to 1.5 minimum wages), equivalent to $50 \%$ of the minimum-wage-based social security contribution, for the first 24 contributions (continuous or discontinuous); and a contribution subsidy paid directly by the State to the young worker's individuallyfunded account, in the same amount as the subsidy described above. This benefit is effective from 1 July 2011.

Source: M. Velásquez Pinto, "El caso de Chile", La seguridad social en América Latina y el Caribe. Una propuesta metodológica para su medición y aplicación a los casos de Argentina, Chile y Colombia, project documents, No. 258 (LCN.258) O. Cetrángolo (ed.), Santiago, Chile, Economic Commission for Latin America and the Caribbean (ECLAC), 2009 


\section{Health care systems}

As discussed in ECLAC (2009b), social protection systems in the region are highly dissimilar, with the differences between countries depending on the relative weight of State, market and family contributions to welfare. The smaller the weight of the State, the more important out- of-pocket spending becomes, and the ability to weather volatile economic cycles is exposed to market forces and family income. This is particularly relevant in the case of health care systems, where the need to incur out-of-pocket expenses to obtain care or medication is a significant source of inequity. The larger the contribution made by public spending the more equitable and redistributive health care spending will be, while a greater proportion of private spending is indicative of a smaller degree of solidarity within the system (ECLAC, 2006; Uthoff, 2010).

Health care system segmentation is present in practically all of the countries of Latin America and the Caribbean. There is a wide variety of health care system institutions and mechanisms for financing, insuring, regulating and providing services that, in general, combine a specialized public system with certain functions of the social security systems and the private sector. The working of the system as a whole depends on how these three subsectors are related.

The public sector is usually the only mechanism for covering the population with no contributory capacity (that is, the uninsured population uses the public network of providers). Some social security systems, in addition to paying pensions, operate health care services, cover formal workers and may have their own network of hospitals and providers. And the private sector usually serves the higherincome population under insurance arrangements and a private- provider structure. As a rule, households in the highest quintiles report a greater degree of participation in insurance systems; families in the first and second quintiles are usually covered by the public system.

Institutional arrangements in the region vary widely, ranging from public services funded exclusively by general revenues, to systems where contributory funding and the national budget are integrated to a certain degree, to the other extreme in countries with little or no connection between the two, as can be seen in box III.1 (ECLAC, 2006). One group of countries has health care systems that provide uniform public benefits for the entire population, funded exclusively by general revenues. This group includes the countries of the English-speaking Caribbean, Brazil and Cuba.

The prevailing system in the countries of the Englishspeaking Caribbean is one in which funding is essentially non-contributory and is based on taxes, with no explicit separation between procurement, insurance and the provision of services (the private sector plays a subsidiary, comple- mentary role to the public sector). There are both public and private providers of health care services. The Cuban health care system is similar to these, but services are provided by the public system alone.

In Brazil, with adoption of the 1988 Constitution the right of workers to health care provided under social security was made universal and comprehensive. That was the starting point for the creation of a single public health care system funded out of general revenues that integrated almost all of the social security schemes. The Brazilian system thus comprises just two subsectors: public and private.

Costa Rica is an example of another kind of system, which combines funding from general revenues and the contributory system. Unlike Brazil, Costa Rica kept wage-based contributions earmarked for an agency (the Costa Rican Social Security Fund) that also receives fiscal contributions to serve those who have no contributory capacity. ${ }^{29}$ The fund operates like an insurance system and provides uniform coverage for all participants. Integrating the different income groups (that use the same facilities and receive the same level of services) has been the main factor behind the success of Costa Rica's health care policy. ${ }^{30}$

Another group of countries comprises those in which the different sources of funding are integrated but coverage is differentiated on the basis of whether the funding is contributory or not. Antigua and Barbuda, Colombia and the Dominican Republic are examples, as Uruguay will be once the reform under way is in place. Colombia is especially interesting, with its health care reform that began in 1993, and is discussed in box III. 2 .

\footnotetext{
29 State participation in funding is through three different channels: (i) the State makes a minor contribution that supplements the one paid in by employees and employers; (ii) it covers nearly $50 \%$ of the contribution for independent workers and voluntary participants; and (iii) it covers $100 \%$ of the contribution for the poorest segment of the population, which lacks contributory capacity.

30 However, over the past few years persons with greater resources have tended more and more to use private primary care and specialized services instead of public services. This has not affected the system's solidarity because this group continues to pay in to social security, but it does create incentives for contributor evasion.
} 
In 1993 Colombia radically changed its health care system and began to transition from the traditional three-tier format seen in many countries in Latin America (public health care system funded by taxes, for the population segment unable to pay; social security system funded by wage-based contributions for formal workers; and private medical care for higher-income segments) towards a universal insurance system. The purpose of the new system is to ensure that the entire population has access to a single package of health care services - the compulsory subsidized health plan (POSS) - regardless of socioeconomic status or risk level. In practice, the reform led to the appearance of several subsystems that are far less segmented than in the previous system. However, differences in access and quality of service do persist, depending on the subsystem and beneficiary population involved.

In the General System of Social Security in Health (SGSSS) inaugurated with the 1993 reform, public and private insurance and service providers coexist and the population is free to choose the insurer. The new arrangement includes the following subsystems:

- Public health care system for the uninsured

- Contributory regime

- Subsidized regime

- Exempt regimes

- Private services for the uninsured
The public health care system is seen as a transitional arrangement for the segment of the population that is still uninsured. It is funded by national taxes and, to a lesser extent, by local taxes. In 2008 this subsystem served $14 \%$ of the population. The contributory regime is geared to the population segment that is able to pay, and its participants are entitled to care under the compulsory subsidized health plan. This regime covered approximately $39 \%$ of the population in 2008 . Contributors pay in $12.5 \%$ of their wages, with 1.5 percentage points being channelled to the subsidized regime to fund the system's solidarity component. In addition, the Health Promotion Agencies (EPSs) receive riskadjusted capitation payments, which adds other redistributive components: income level, age and health status.

The subsidized regime serves the insured population that is unable to pay, subject to a means test for eligibility. In this subsystem, members are entitled to care under the compulsory subsidized health plan, which is more limited than under the contributory regime. In 2008 nearly $44 \%$ of the population belonged to this system. Funding comes from the solidarity contribution made by members of the contributory regime (approximately $34 \%$ of the subsidized regime's budget revenues in 2009) and from national and local taxes (which accounted for $64 \%$ of revenues that same year).
In addition to these subsystems, there are the so-called exempt regimes. These regimes receive contributions from members and have their own mechanisms for engaging health care system providers. The average contribution is higher than for the other regimes and the services provided are better, with the resulting inequities. These regimes offer coverage for members of the armed forces and the national police force, employees of the Colombian Petroleum Company (ECOPETROL) and other closed groups of public servants. It is estimated that $3 \%$ of the population belonged to these regimes in 2008 .

High-income individuals usually belong to private plans for complementary coverage; approximately $6 \%$ of the population does so. To keep participation in such plans from draining resources from the general system, participation in the contributory regime is a requisite for joining an additional, private coverage plan.

Despite the successful outcomes of the reform, there are still barriers to health care access in Colombia and inequities therefore persist. The reasons for the remaining segmentation lie in the attempt to preserve the status quo, both by the beneficiaries of the old social security system and by other groups and institutions (public and private health care organizations, medical associations and others).

Source: Úrsula Giedion and Olga Lúcia Acosta, "El impacto distributivo de la reforma colombiana de 1993", document presented in the workshop on distributive impact in public policies, Santiago, Chile, Economic Commission for Latin America and the Caribbean (ECLAC), 28-29 April 2010.

Among the systems with a certain degree of integration is Chile's, as a unique variant that could be classed as a dual, partially integrated model. One of the salient features of the reform initiated in 1981 was segmentation, with compulsory contributions to the health care system that could be earmarked, at the contributor's choice, for a sort of public health insurance plan - the National Health Fund (FONASA) - or for private health insurance institutions (ISAPRE). If the compulsory contribution is earmarked for the National Health Fund, the contributor is a member of the public system. If the contribution is channelled to a private health insurance institution, the member is covered by one of the health plans it offers, depending on payment capacity and risk. In this system, the public sector and social security are linked through the National Health Fund and the Universal Access with Explicit Guarantees (AUGE plan). ${ }^{31}$ The National Health Fund is funded by contributions from members and fiscal

31 The AUGE plan covers a set of health conditions for which care is guaranteed by both the public system and the private system. contributions out of general revenues, to provide coverage for those with no contributory capacity. Within the National Health Fund, access to AUGE plan benefits is not tied to contributions. At this basic level, then, there is solidarity among contributors and noncontributors. For access to other National Health Fund services, however, there are co-payments that vary depending on the beneficiary's income bracket and the cost of the service. Despite this solidarity mechanism, the duality of the system as a whole and the individual nature of private insurance coverage hamper the complete integration of funding and work against equality.

Unlike Colombia, where there are risk compensation mechanisms, private insurance in Chile leads to discrimination based on individual contributors' health risks and thus to situations that run contrary to the goals of rightsbased social policy. First, the marked difference between health programme premiums discriminates against women of child- bearing age and older adults, because of their higher health risks. Second, this difference leads, in practice, to private insurers screening participants 
Table III.1

LATIN AMERICA AND THE CARIBBEAN: COMBINATIONS OF PUBLIC FUNDING AND SOCIAL SECURITY CONTRIBUTIONS IN THE HEALTH SECTOR ${ }^{a}$

\begin{tabular}{|c|c|c|}
\hline Type 1 & Type 2 & Type 3 \\
\hline $\begin{array}{l}\text { Countries with health care systems } \\
\text { financed by general revenues }\end{array}$ & $\begin{array}{l}\text { Countries with health care systems financed } \\
\text { by a combination of general revenues } \\
\text { and social security contributions }\end{array}$ & $\begin{array}{l}\text { Countries that do not combine } \\
\text { general revenues and social security } \\
\text { contributions for financing health care }\end{array}$ \\
\hline $\begin{array}{l}\text { Services are structurally varied: different } \\
\text { types of relationship exist between } \\
\text { the public and private sectors. }\end{array}$ & $\begin{array}{l}\text { In all cases, there is a certain degree of } \\
\text { explicit separation between financing and } \\
\text { the provision of services. The degree to } \\
\text { which financing is integrated varies as well. }\end{array}$ & $\begin{array}{l}\text { Services are structurally varied: different } \\
\text { types of relationship exist between } \\
\text { the public and private sectors }\end{array}$ \\
\hline $\begin{array}{l}\text { Countries with public and private services: } \\
\text { Bahamas, Barbados, Belize, Bolivarian } \\
\text { Republic of Venezuela, Brazil, Dominica, } \\
\text { Grenada, Guyana, Haiti, b Jamaica, Saint Kitts } \\
\text { and Nevis, Saint Lucia, Saint Vincent and the } \\
\text { Grenadines, Suriname, Trinidad and Tobago }\end{array}$ & $\begin{array}{l}\text { Antigua and Barbuda, Dominican Republic, }{ }^{c} \\
\text { Costa Rica, Colombia, Chile, Uruguay }\end{array}$ & $\begin{array}{l}\text { Argentina, Ecuador, El Salvador, } \\
\text { Guatemala, Honduras, Mexico, } \\
\text { Nicaragua, Paraguay, Peru, Panama, } \\
\text { Plurinational State of Bolivia }\end{array}$ \\
\hline \multicolumn{3}{|l|}{$\begin{array}{l}\text { Countries with services provided by } \\
\text { the public system only: Cuba }\end{array}$} \\
\hline $\begin{array}{l}\text { Source: Economic Commission for Latin America and the } \\
\text { Santiago, Chile, February } 2006 \text {. } \\
\text { a In all countries, except Cuba, there is also a private s } \\
\text { b In Haiti there is practically no social security, a } \\
\text { governmental organizations. } \\
\text { c The Dominican Republic is in a transition period, im }\end{array}$ & $\begin{array}{l}\text { bean (ECLAC), Shaping the Future of Social Protectio } \\
\text { tor that provides health services. } \\
\text { provision and financing of health services are } \\
\text { ating health reforms aimed at greater integration of fi }\end{array}$ & $\begin{array}{l}\text { ess, Financing and Solidarity (LC/G.2294(SES.31/3)/E), } \\
\text { rtaken principally by the public sector and non- } \\
\text { g. }\end{array}$ \\
\hline
\end{tabular}

based on risk, accepting those with a lower risk profile and shunting riskier, less profitable groups to the public system.

Another group consists of those countries in the region that have systems where public funding and social security are not integrated. Generally speaking, in this group fairly fragmented social security systems coexist with multiple institutions; there are no mechanisms for coordination and little solidary funding. ${ }^{32}$

To make a health care system more equitable, moving toward universal coverage should be a priority. The minimum requirements for attaining this goal are reconciling the subsystems (public, social security and private medicine); integrating contributory and non-contributory sources of funding by incorporating explicit, transparent solidarity features; and lowering the barriers to health care access for lower-income population segments, ensuring efficient and quality care.
32 The countries in this group are Argentina, Ecuador, El Salvador, Guatemala, Honduras, Mexico, Nicaragua, Panama, Paraguay, Peru, Plurinational State of Bolivia and Uruguay.

\section{Education systems}

It is generally agreed that education furthers inclusive development. A society with good education outcomes that extend to most of the population tends to have less income dispersion. This is due to increasing income from work and the positive impact in terms of health, the integration of the population into networks and access to decision-making levels.

According to the Universal Declaration of Human rights, everyone has the right to free education (at least in the elementary and fundamental stages), and education shall be compulsory. ${ }^{33}$ But, beyond coverage, there is concern as to the quality of education services provided. From a rights-based point of view, a quality education enables students not only to acquire knowledge and skills but also to develop values, attitudes and behaviours (UNESCO and OREALC, 2008).

In this sense, education coverage in the countries of the region has improved considerably since 1990 . School attendance among primary-school age children is almost universal. Access for children and young people at higher levels has increased thanks to expanded school coverage and better education system retention capacity (ECLAC, 2007). But the significant progress made in access to education is still marred by the high degree of inequality in terms of education received and learning skills acquired that has its root in the unequal social structure of the countries of the region.

Generally speaking, public and private education systems coexist in the Latin American and Caribbean countries. Public education is financed for the most part by

33 United Nations, 1948 
central or national government budget resources, by intermediate governments (such as provinces and states), or by local or municipal governments, as well as by private- sector resources (such as donations and transfers). Private education is financed by payments from users.

The relative importance of private financing has increased in the region, as has family spending on education. This has an effect on distributive impact (ECLAC and UNESCO, 2004). If spending is proportional to a family's budget and its elasticity depends on the resources or savings at the family's disposal, it is to be expected that an increase in private spending favours the concentration of more resources in higher-income groups where education outcomes in terms of years of schooling and effective learning are already better than for the rest of society. Family contributions account for most private spending on education, so consideration must be given to their impact on equity, that is, on the equality of opportunities for access and attainment and on the education system for girls and boys from different socio- economic groups, ethnicities and localities. If increasing the family contribution has a direct impact on the quality of education that the children receive, there is a clear risk that the gap in education outcomes among social strata will tend to grow rather than decrease.
There are two types of public financing: (i) resources channelled to the education sector by supply mechanisms; and (ii) those based on demand, via subsidies for students and their families. In Latin America, the dominant models are those in which resources are allocated directly on the basis of supply, depending on the specific features of each school. Chile, on the other hand, is an example of a demand-oriented mechanism. Between 1980 and 1986, approximately, Chile underwent one of the most radical reforms that have ever taken place in the region. Education was decentralized and made the responsibility of municipalities, and the groundwork was laid for a marked increase in the role of private education in providing services to the system. But this scheme had a regressive distributive bias that democratic administrations sought to correct with successive reforms. ${ }^{34} 10$

A strategy for achieving equality in education must give priority to expanding coverage at the preschool level and lengthening the school day in public schools, improving secondary completion rates in socio-economic sectors with lower achievement levels (considering that coverage and completion are now almost universal for primary education in the region) and reducing the learning and knowledge gaps built up over the education cycle from preschool to the end of the secondary cycle) (ECLAC, 2010b).

\footnotetext{
34 Chile's education finance system consists of a portable, demand- side per-student subsidy that is given to the establishment where the student is enrolled. Over the past few years, the system has changed considerably from its original design. Legislation enacted in 1993 authorized co-payments by parents to subsidized establishments. To address the increasingly regressive nature of the education system, in 2007 Congress passed the Preferential School Subsidy Act targeting priority or vulnerable students. New programmes were implemented as well; the level and structure of teacher pay scales were changed, and other, minor payments were added based on the characteristics of each establishment. Further changes were made over time without altering the core of the system — a fully portable perstudent subsidy — despite the fact that the underlying problem with the system was its highly regressive nature. See Romaguera and Gallegos (2010).
} 


\subsection{Assigning functions to different levels of government}

An additional factor to consider when assessing the distributive impact of social policies has to do with the level of government responsible for providing them. Over the past 30 years, the Latin American and Caribbean region has seen the decentralization of many competencies and functions that have been reassigned from the central government to subnational levels.

This devolution of responsibilities to intermediate and local governments entailed a substantial increase in public spending at the subnational level in the past few decades. Table III. 2 shows the marked rise in subnational government spending in some countries, such as Argentina, Colombia, Ecuador, Mexico, and the Plurinational State of Bolivia. The level of subnational spending is closely linked to the institutional framework of the country in question and is more than eight percentage points of GDP in federal countries (averaging 13\% of GDP in Argentina and Brazil) and in decentralized unitary countries like Colombia. In such countries, subnational governments account for $25 \%$ to $45 \%$ of total non-financial public sector spending. Moreover, these countries are usually those with a larger geographical area and greater internal disparities, making decentralization more of a governance tool than an option for public policy and for organizing social services.

The increase in subnational government spending took place mainly in the education and health sectors, which became a priority in the region's more decentralized countries and account for more than $40 \%$ of total subnational government spending (di Gropello and Cominetti, 1998; Cetrángolo, 2007). In Argentina, Brazil, Colombia and the Plurinational State of Bolivia, subnational governments execute more than $70 \%$ of total public spending on education and approximately one half of public spending on health (see figure 25).

Table III.2

LATIN AMERICA: SUBNATIONAL GOVERNMENT SPENDING ${ }^{a}$

(Percentages of GDP and of total non-financial public sector or central government spending)

\begin{tabular}{|c|c|c|c|c|c|c|c|c|c|}
\hline & $1985-1990$ & 1991-1995 & $1996-2000$ & $2001-2005$ & 2006-2008 & 1991-1995 & $1996-2000$ & $2001-2005$ & $2006-2008$ \\
\hline & \multicolumn{5}{|c|}{ (percentage of GDP) } & \multicolumn{4}{|c|}{$\begin{array}{l}\text { (percentages of total non-financial public sector } \\
\text { or central government spending) }\end{array}$} \\
\hline Argentina & 8.7 & 11.0 & 11.9 & 12.0 & 14.0 & 44.7 & 44.8 & 45.1 & 45.3 \\
\hline \multicolumn{10}{|l|}{$\begin{array}{l}\text { Bolivia } \\
\text { (Plurinational }\end{array}$} \\
\hline State of) & 2.8 & 5.6 & 6.9 & 7.8 & 10.7 & 15.4 & 19.9 & 22.1 & 26.5 \\
\hline Brazil Chile & $\ldots$ & $\ldots$ & 12.2 & 12.3 & 12.6 & $\ldots$ & 33.0 & 31.4 & 31.5 \\
\hline Colombia $^{b}$ & 2.3 & 2.3 & 3.0 & 3.0 & 2.6 & 7.3 & 9.5 & 9.0 & 7.9 \\
\hline Costa Rica & 5.2 & 5.0 & 7.3 & 7.7 & 8.2 & 23.3 & 23.5 & 24.4 & 26.6 \\
\hline Ecuador & 0.8 & 0.6 & 0.7 & 0.8 & 0.9 & 2.6 & 2.9 & 2.9 & 3.6 \\
\hline Mexico & $\ldots$ & 1.8 & 2.2 & 3.7 & 4.3 & 7.5 & 9.1 & 15.6 & 14.2 \\
\hline Paraguay & 3.8 & 4.6 & 6.2 & 7.9 & 8.4 & 21.9 & 30.0 & 37.1 & 37.3 \\
\hline Peru & 0.4 & 0.3 & 0.3 & 0.4 & 0.4 & 1.0 & 0.9 & 1.1 & 1.3 \\
\hline \multirow{2}{*}{$\begin{array}{l}\text { Average for } \\
\text { Latin America }\end{array}$} & $\cdots$ & 1.8 & 2.0 & 2.1 & 3.0 & 9.2 & 9.8 & 10.9 & 16.3 \\
\hline & $\ldots$ & $\ldots$ & 5.3 & 5.8 & 6.5 & $\ldots$ & 18.4 & 20.0 & 21.1 \\
\hline
\end{tabular}

Source: Economic Commission for Latin America and the Caribbean (ECLAC).

The data on subnational governments in Argentina are for provinces; for the Plurinational State of Bolivia they refer to prefectures and municipalities; in Brazil, they are for states and municipalities; in Chile, they are for municipalities; in Colombia, they refer to departments and municipalities; in Costa Rica, they are for local governments; in Ecuador, they refer to provincial councils and municipalities; in Mexico, they are for state governments and the Federal District; in Paraguay, they refer to Governor's Offices; and in Peru they are for local governments.

b The data in the first column refer to 1986-1990. 
(a) Percentages of total subnational spending

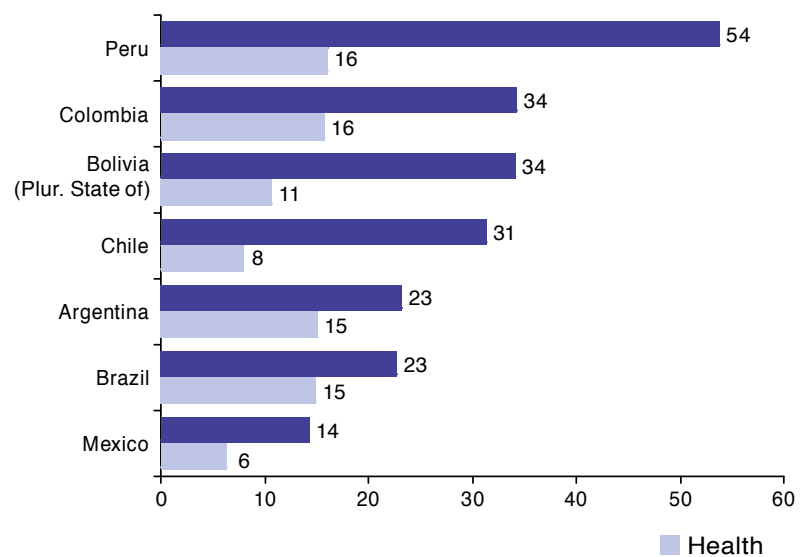

(b) Percentages of total public spending on education and health

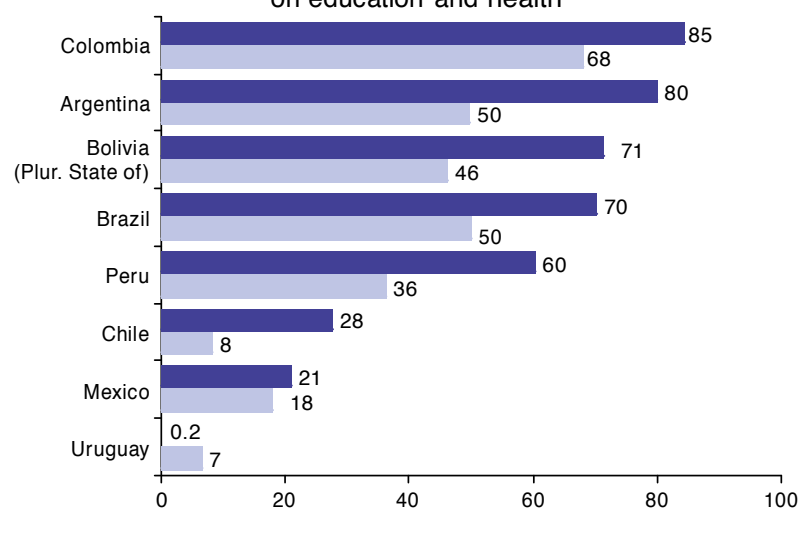

Source: Economic Commission for Latin America and the Caribbean (ECLAC), on the basis of official information.

To appropriately weight the importance of subnational governments in the application of social policies, the features of programmes geared to improve social protection and fight poverty must be borne in mind. It is usually held that for reasons of efficiency and equity, central governments should be responsible for designing and funding such programmes. In practice, however, either circumstances or ongoing decentralization are making programmes executed by intermediate and local governments increasingly widespread. Box III.3 classes social protection and anti-poverty programmes on the basis of the level of government executing them.

Classifying these programmes in Latin America reveals how difficult it really is to distribute functions among jurisdictions on the basis of theory and regulations.

Table III.3 summarizes the proposed classification, with examples from each case. Initiatives to combat poverty and improve social protection are being implemented across the region by different levels of government. Particularly noteworthy is the existence of many central government programmes that deal with decentralized issues. Even more striking are the local programmes that address issues associated with centralized policies. Some attempts at comprehensive policies linking initiatives at different levels of government were identified, but this has not always been the case. In any event, it is clear that the enormous diversity of situations in the region requires a major effort to coordinate the different levels of government at times of increased demand for these programmes.
Beyond the theoretical grounding of and the specific rationale underlying each national experience with decentralization, it is important to note that the devolution of functions to subnational levels of government is subject to a set of conditioning factors and limitations of such consequence that they have sparked considerable tension between decentralization and other policy objectives. Particular attention should be paid to conflicts with fiscal sustainability andterritorial and social cohesion.

The decentralization of functions increases the demand for resources by subnational governments so they can provide social services, and it can trigger fiscal tensions. In addition, increased local autonomy generates pressure in wealthier regions to stop contributing to the maintenance of public policies in poorer areas, thus jeopardizing social and territorial cohesion. So, while there have been many attempts to introduce varying degrees of decentralization, the outcomes unquestionably reflect the strengths and weaknesses of each country and, above all, the financing mechanisms accompanying each process (Arredondo, Orozco and De Icaza, 2005).

It is thus important to bear in mind the factors that substantially condition attainment of the objectives pursued by public decentralization policies. The first factor, mentioned in chapter II, has to do with the difficulties that the countries of the region face in collecting adequate tax revenues. Second, the high and unequal territorial distribution of tax bases makes it very difficult to fulfil the fiscal co-responsibility goals that many of the ongoing decentralization processes would require.

While the main source of financing for the public sectors is taxes, these are concentrated mainly at central government levels. As figure 26 shows, in the more de- 
Table III.3

LATIN AMERICA: CLASSIFICATION OF PROGRAMMES BY LEVEL OF GOVERNMENT

\begin{tabular}{|c|c|c|}
\hline Programmes & Responsibility of central government & Responsibility of local government \\
\hline \multirow[t]{3}{*}{ Traditionally centralized } & $\begin{array}{l}\text { Income transfers: Chile Solidario; Unemployed } \\
\text { Heads of Household Plan or PJJHD } \\
\text { (Argentina); development strategy for } \\
\text { depressed and conflict areas (Colombia) }\end{array}$ & $\begin{array}{l}\text { Employment and job training: Girasoles } \\
\text { Programme (Montevideo); provincial } \\
\text { employment programmes (Argentina) }\end{array}$ \\
\hline & $\begin{array}{l}\text { Food programmes: Emergency Hunger Programme } \\
\text { (Argentina); Zero Hunger (Brazil); family } \\
\text { assistance and nutrition programme (Colombia); } \\
\text { supplemental food programme (Peru); school meal } \\
\text { and child nutrition programme (Guatemala) }\end{array}$ & $\begin{array}{l}\text { Programmes coordinated with other levels of } \\
\text { government: Local food security, nutritional } \\
\text { analysis and education project, Corral } \\
\text { de Bustos municipality (Argentina) }\end{array}$ \\
\hline & $\begin{array}{l}\text { Employment: Getting to Work (Argentina); programme } \\
\text { to eradicate child labour (Brazil); employment } \\
\text { and job training programme (Colombia) }\end{array}$ & \\
\hline \multirow[t]{4}{*}{ Traditionally decentralized } & $\begin{array}{l}\text { Distribution of material for decentralized } \\
\text { functions: book distribution (Brazil); }\end{array}$ & $\begin{array}{l}\text { Provision of decentralized services: Family Health } \\
\text { Programme (Brazil); mobile health programme (Lima) }\end{array}$ \\
\hline & $\begin{array}{l}\text { Remediar programme (Argentina) } \\
\text { Guaranteed minimum spending: Fund for the } \\
\text { Maintenance and Development of Primary Education } \\
\text { and for Teacher Development (FUNDEF) (Brazil) } \\
\text { Support for local capacities: fiscal decentralization } \\
\text { and municipal financial management, and } \\
\text { decentralization of public services (Honduras) }\end{array}$ & $\begin{array}{l}\text { Assistance programs: Summer programme } \\
\text { for street children, and neighbourhood } \\
\text { snack and meal centres (Montevideo) } \\
\text {. Urban development: multi-sector investment } \\
\text { programmes (Brazil); subsidy for public transit } \\
\text { tickets and suspension of property taxes owed } \\
\text { by lower-income homeowners (Montevideo) }\end{array}$ \\
\hline & $\begin{array}{l}\text { Programmes coordinated with local programmes: } \\
\text { Emergency Housing Programme (Argentina) }\end{array}$ & \\
\hline & $\begin{array}{l}\text { Urban development: Urban quality of life } \\
\text { programme (Colombia); subsidy for drinking } \\
\text { water and sanitation service bills (Chile); } \\
\text { Guatemalan Housing Fund (Guatemala) }\end{array}$ & \\
\hline Comprehensive initiatives & $\begin{array}{l}\text { - National strategies: strengthening local } \\
\text { development (Honduras); Poverty Reduction } \\
\text { Strategy, or ERP (Nicaragua) }\end{array}$ & $\begin{array}{l}\text { Programa Crecer (Rosario, Argentina); creation } \\
\text { of municipal agencies (Lurin, Peru); Committee } \\
\text { to Fight Poverty (Villa María del Triunfo, Peru) }\end{array}$ \\
\hline
\end{tabular}

Source: O. Cetrángolo, "Búsqueda de cohesión social y sostenibilidad fiscal en los procesos de descentralización", Políticas sociales series, No. 131 (LC/L.2700-P), Santiago, Chile, Economic Commission for Latin America and the Caribbean (ECLAC), 2007. United Nations publication, Sales No. S.07.II.G.50 S.07.II.G.50.

centralized countries subnational governments contribute nearly $20 \%$ of total tax revenue. In Brazil, states and municipalities collect approximately one third of the total, due mainly to revenue from the sales tax on merchandise and services (ICMS), which is in the purview of the states and the federal district. In more centralized countries such as Chile, Costa Rica and Ecuador, on the other hand, subnational governments collect less than $6 \%$ of the total. Although Mexico is a federal country, tax collection is centralized at the federal government level; states and municipalities account for just $6 \%$ of tax collections. ${ }^{35}$

Total subnational government tax revenues have grown substantially over the past 10 years. However, this is due essentially to the growing importance of transfers from central governments, not to an increase in their own fiscal resources. As figure 27 shows, transfers as a percentage of subnational government revenue rose substantially between 1997 and 2008 while their own tax revenues just went from $2.1 \%$ of GDP to $2.6 \%$ of GDP during the same period.

35 For more details, see J.P. Jiménez and Podestá (2009).
A country-by-country analysis of the revenue structure at these levels of government shows that transfers are substantial in most of them. In Argentina, Mexico and the Plurinational State of Bolivia, they exceed seven percentage points of GDP; in Colombia and Ecuador they are in the area of $4 \%$ of GDP. In Ecuador and Mexico, transfers received by intermediate and local levels of government are the main source of funding, at $70 \%$ of total revenue.

Factors ranging from the high degree of productive disparity in the region to weak subnational tax collection agencies are behind the slow growth of subnational revenues and the high degree of dependence on intergovernmental transfers (Cetrángolo and J.P. Jiménez, 2009). As stated earlier, tax collections by subnational governments have stagnated over the past 11 years and the gaps in subnational tax pressure among the countries of Latin America have remained constant. ${ }^{36}$ The poor evolution of subnational tax collections in the countries of the region is related to the inadequate level and structure of subnational taxes, which are, in turn, related to the available tax base.

36 The only countries in which the subnational tax burden has increased are Brazil and the Plurinational State of Bolivia. In Brazil, however, as highlighted by Afonso (2004), the sales tax on merchandise and services has increased less than indirect federal taxes have, because of fiscal competition between the states concerning this tax. 
Figure 26

LATIN AMERICA: TAX COLLECTION STRUCTURE BY LEVEL OF GOVERNMENT, 2008

(Percentages of total collections and of GDP)

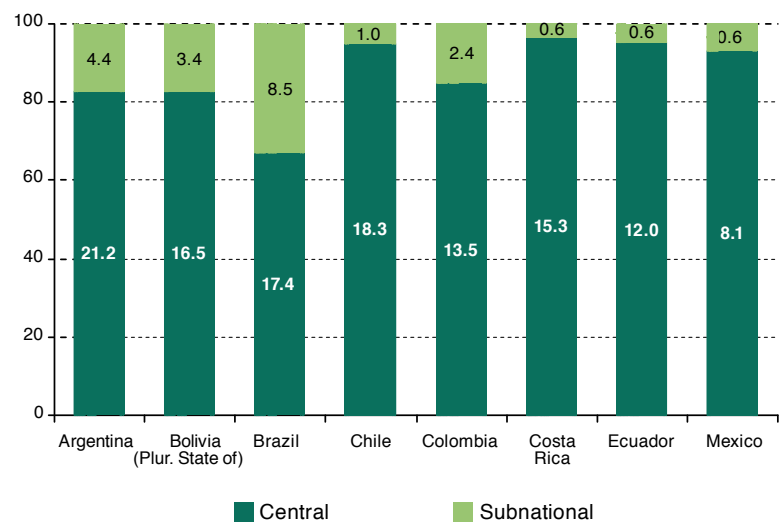

Source: Economic Commission for Latin America and the Caribbean (ECLAC), on the basis of official information.

Figure 27

LATIN AMERICA: AVERAGE STRUCTURE OF SUBNATIONAL REVENUES, 1997-2008

(Percentages of GDP)

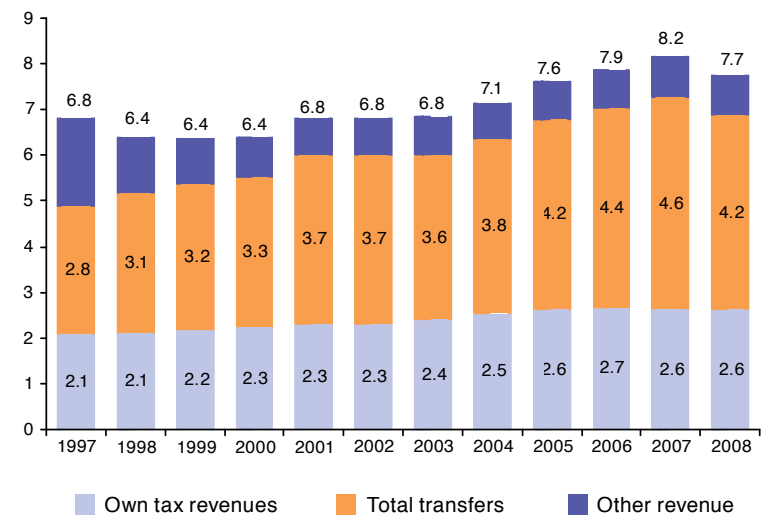

Source: Economic Commission for Latin America and the Caribbean (ECLAC), on the basis of official information.

Because the rationale and logic behind the territorial assignment of functions differ from those that have shaped the distribution of taxation authority, the countries usually exhibit varying degrees of imbalance between receipts and payments.13 They are reflected in the gap between resources and spending at the different levels of government (vertical imbalance), or in the gap between the fiscal capacities of subnational governments at the same level (horizontal imbalance), rooted in productive disparities at the regional level. These imbalances are usually covered by financial transfers (Ahmad and Craig, 1997).

Given the horizontal imbalance, the more advanced the decentralization of functions, the larger the vertical imbalance will be. This does not mean that decentralization impedes the pursuit of greater social cohesion, only that it highlights the need for mechanisms to coordinate sectoral policies that provide for compensating needier regions. That is the only way to craft decentralization policies that maintain social cohesion and are fiscally sustainable over the medium term.

Also, the more centralized taxation is the greater the need for basic transfers to finance activities that are in the hands of subnational governments. Since they are so dependent on attainment of the social cohesion goals of the transfer system in question, it is impossible to evaluate decentralization processes and the likelihood of local governments being able to carry out their functions without considering interjurisdictional financial transfer schemes. Indeed, the fiscal impact will be very different depending on the modality adopted in each case.

There is considerable diversity among transfer schemes in the region, depending on the level of government, making it very difficult to identify common traits that might reveal a pattern. Among the systems in place there are (i) unconditional transfers, which give local governments greater authority and seek to lessen the differences between the financial capacities of the states; the magnitude of the transfers depends on central government collections and thus is highly procyclical and more problematic from a fiscal sustainability point of view; (ii) conditional transfers, which are usually present when the central government targets a particular policy objective and the resources transferred are tailored to central government priorities, usually due to the incomplete decentralization of a certain function; and (iii) transfers with a counterparty, which are of particular interest because they involve incentives for subnational governments to fulfil certain decentralized policy goals defined by the central government for the sectoral policy in question.

In any event, even if the requisite financial resources are available, the serious disparities existing at the territorial level limit the availability of human resources and, in general, of management capacities. This means that, in addition to the transfer of monetary resources, training and capacity transfers are needed as well. There is therefore no denying the need to continue to re-think the hierarchical role of central governments in decentralized countries, implementing sectoral policies that provide for interregional compensation and make it possible to guarantee basic social services for the entire population. 


\section{Conclusions}

To improve distributive impacts and promote equality and social cohesion in Latin America and the Caribbean, effective public policies will be required in a variety of key areas. First, public policy needs to achieve the greatest possible results in terms of economic growth and employment, since without steady, sustained growth in the economy the demand for social assistance proliferates while the resources needed to finance the necessary State actions are hard to obtain. Second, modernization of social policies is vital, and this includes both education and vocational training policies designed to increase people's capabilities and policies constituting a rights-based social protection paradigm. Furthermore, these can have a positive feedback effect on economic growth.

There is conclusive empirical evidence for the impact that macroeconomic crises and high levels of volatility have on the relative situation of the poorest sectors of the population. It is they who bear the brunt when incomes fall, and they lack the resources to cushion the negative effects of macroeconomic shocks, characterized as these are by falling incomes, job losses and reduced social benefits.

Recognizing that stability is a necessary condition for stronger growth and better distribution means setting out from broadly defined macroeconomic policy goals that are not confined to inflation control but encompass the need to reduce real-term volatility through measures, policies and institutions capable of smoothing the fluctuations caused by external and internal shocks and those originating in macro policy and its impacts.

In a region characterized by a highly heterogeneous production structure, reflected in the labour market by large productivity and earnings divides, the rate and characteristics of growth have a strong influence on income distribution and on the kind of access different social groups have to the goods and services produced in the economy. From this perspective, the way different groups participate in markets (the labour market, for instance) entails significant differences in the extent to which policies affect them. Again, aggregate volatility generates greater fluctuations in the incomes of poorer households, especially when, as in our region, unemployment is higher in the poorer strata and this lack of job opportunities drives people into informality. As ECLAC has often argued, crises have consequences in terms of employment, poverty and inequity which are not quickly reversed during upturns and whose effects on inequality are lasting and may even become permanent if the educational careers of young people from poor families are cut short.
The decline in the social assistance capacity of the State during periods of recession in the region, owing to the procyclical character of public social spending, adds a further element of volatility to the consumption of the poor, exposing them to an additional policy risk. This highlights the need for greater policy space so that, in the particular case in hand, instruments are in place to protect the neediest at the time when this is generally most necessary, in the downturns of the economic cycle.

One of the keys to creating this policy space is the development of countercyclical fiscal capacities or fiscal positions that are sustainable over time so that programmes to counteract the social effects of recessions, such as unemployment and increased poverty, can be strengthened as required. This does not just mean trying to balance public spending and revenue, however. An increasingly important development has been the demand for public action that is more efficient and transparent, while at the same time offering scope for greater citizen involvement. This would contribute to the legitimacy of public policies and of the taxes needed to sustain them over time, while making it possible to break the vicious circle whereby States are unable to collect taxes in part because their activities do not enjoy the necessary legitimacy among citizens, whether because of shortcomings and gaps in their mode of action or because of a lack of financing.

The region's fiscal systems share three common characteristics: (i) low tax pressure, (ii) regressive taxation and (iii) poorly directed public spending. On the revenue side, the level of taxation, tax structures and large-scale fraud and tax avoidance all have major effects on equity. For one thing, citizens' social needs are impossible to meet without financial resources. For another, evasion poses a serious problem of equity in that the failure to meet tax obligations results in other taxpayers having to pay more and/or in public goods and services being forfeited.

While there has been some progress in these areas in recent years, the situation is still generally characterized by tax structures that rely heavily on consumption taxes, by high levels of evasion and avoidance and low yields from direct taxes such as income tax, especially the portion payable by natural persons (particularly when compared with levels in developed countries), and by low or non- existent property taxes.

There are two basic reasons for the low relative level of direct taxation in the region, namely narrow tax bases and high levels of non-payment. The end result is taxation rates that are too low to achieve economic effects of any considerable scale. Both of these phenomena are also a 
consequence of the tax breaks and loopholes characteristic of the region's taxation systems. Not only does this situation fail to meet the basic requirements of equity, i.e., that people with the same payment capacity should pay the same amount of tax (horizontal equity) and that people with a greater payment capacity should pay proportionally more (vertical equity), but it gives rise to economic distortions in resource allocation that impair the overall efficiency of the economy.

As noted earlier, public spending that was oriented towards the creation of more cohesive societies would make a huge contribution to the legitimacy of the State and people's willingness to finance its activities by paying tax. Where social policy is concerned it must be realized that, contrary to the claims made until a few years ago, the labour market is not enough by itself to guarantee social integration. Consequently, as analysed in earlier documents (ECLAC, 2006 and 2010b), social protection cannot rely exclusively on the capacity of contributory systems associated with employment, which means there is a need to give fresh thought and importance to solidarity mechanisms. Better distribution is not just the outcome of higher public social spending but also depends on the ability to incorporate and improve solidarity transfer mechanisms as part of the benefits provided. This in no way invalidates the importance of strategies to formalize employment relationships by extending labour institutions, with all the rights and duties entailed for both workers and employers. Other labour market policies to address aspects of inequality in this area are unemployment insurance, training mechanisms (especially for workers with an intermediate or low education level) and income policies.

Where health systems are concerned, priority must be given to the process of universalizing basic benefits by making the system more equitable, combining contributory and non-contributory financing and bringing in solidarity transfer schemes and/or risk compensation mechanisms to minimize the barriers to health service access for the less well-off. A number of preliminary tasks need to be performed before this goal can be reached, however, such as coordinating public subsystems, social security and the private sector while at the same time consolidating the two types of financing (contributory and non-contributory).

Regarding education, there is general agreement as to its contribution to more inclusive development and as to the significant increase in coverage achieved in the region's countries. There is still a great deal of work to be done, however, when it comes to expanding coverage in areas such as preschool education, evening out the quality of the education provided by reducing segmentation in education systems, and improving the generation of capabilities that can bring about greater equality in our societies while at the same time enhancing the ability of our economies to compete in a globalized world.

Analysis of public-sector education and health service provision needs to be taken down to the territorial level, particularly in view of the region's characteristics. Over the past 25 years, the region has seen a far-reaching process of decentralization of powers and functions to subnational governments. This process, encompassing almost all the Latin American countries, has varied greatly in characteristics and scope. Apart from the avowed goals of each reform, they have all had significant effects on macroeconomic performance, income distribution and the public accounts. Different circumstances have often given rise to severe strains between these policy objectives. These strains have manifested themselves differently in each case, and have usually had a significant impact on the relations between different levels of government in each country.

The advantages of having different levels of government are connected with the benefits of centralizing decision- making for matters requiring national policies and allowing public choices to be made locally when this is more advantageous. The situation can vary greatly depending on the public good or service being decentralized. Decisions about the organization of decentralized public services are taken in diffuse and complex ways, as they do not depend on the decision to decentralize as such but on a whole array of circumstances and decisions among which determinations relating to sectoral and territorial policies are to the fore.

The expected benefits of decentralization need to be evaluated in the light of the conditions under which reform is being implemented, and it is indispensable here to recognize a number of peculiarities characterizing Latin America and the Caribbean, such as the high level of distributive inequality, the territorial inequality resulting from highly unbalanced development and the public policy constraints imposed by low levels of tax pressure. Throughout the region, these characteristics affect the capacity of governments to raise the desired amounts of tax revenue locally and make it harder to achieve the goals pursued by public-sector decentralization policies.

Once the impossibility of achieving full decentralization with financially autonomous local governments has been accepted, consideration must be given to the need for large-scale intergovernmental financial transfers to deal with the vertical and horizontal imbalances of subnational governments and facilitate the attainment of social cohesion goals. To achieve this objective, it is necessary to reassess the role of central governments, giving 
greater importance to the task of balancing out differences between regions and coordinating public policies that have a common core, even if they are decentralized to different degrees.

To synthesize, the region's countries are faced with a common challenge that entails the necessity of "moving towards greater equality in access, especially in fields such as education, health, employment, housing, basic services, environmental quality and social security" (ECLAC, 2010b, p. 11). The reforms needed to close the social divides that characterize the region require a high degree of consensus and political will, as well as the institutional and administrative capacity to oversee the quality of social spending.

In summary, public policies must secure the financing needed to improve citizen access to social provision in a way that combines efficiency with solidarity, relevance and universality, all at the most appropriate level of government. This should be the basis for the new fiscal covenant that is needed. Achieving it will require an unremitting effort to build increasing consensus on each of the aspects involved, at a time of rising demands for transparency in the use of resources and higher standards of accountability. Public policies commensurate with the challenges facing the region require a constant effort to learn and rethink the kinds of intervention needed to overcome poverty and inequality and to increase people's sense of belonging to a growing economy. 


\section{Bibliography}

Agosin, Manuel R., Alberto Barreix and Roberto Machado (eds.) (2005), Recaudar para crecer. Bases para la reforma tributaria en Centroamérica, Inter-American Development Bank (IDB).

Agosin, Manuel R. and others (2004), "Panorama tributario de los países centroamericanos y opciones de reforma", Serie de estudios económicos y sectoriales, No. RE2-04-010, Inter-American Development Bank (IDB).

Ahmad, Ehtisham and Jon Craig (1997), "Intergovernmental transfers", Fiscal Federalism in Theory and Practice, Washington, D.C., International Monetary Fund (IMF).

Airola, Jim and Chinhui Juhn (2008), "Wage-inequality in post-reform Mexico", Journal of Income Distribution, vol. 17, No. 1.

Alesina, Alberto and Roberto Perotti (1996), "Income distribution, political instability, and investment", European Economic Review, vol. 40, No. 6.

Altimir, Oscar, Luis Beccaria and Martín González Rozada (2002), "Income distribution in Argentina, 1974-2000”, CEPAL Review, No. 78 (LC/G.2187-P), Santiago, Chile, Economic Commission for Latin America and the Caribbean (ECLAC), December.

Arabsheibani, G.Reza, Franscisco Galrão Carneiro and Andrew Henley (2003), "Human capital and earnings inequality in Brazil, 1988-1998: quintile regresión evidence", Policy Research Working Paper, No. 3147, Washington, D.C., World Bank.

Arredondo, Armando, Emanuel Orozco and Esteban De Icaza (2005), "Evidences on weaknesses and strengths from health financing after decentralization: lessons from Latin American countries", The International Journal of Health Planning and Management, vol. 20, No. 2.

Atal, Juan Pablo, Hugo Nopo and Natalia Winder (2009), New Century, Old Disparities. Gender and Ethnic Wage Gaps in Latin America, Washington, D.C., Inter-American Development Bank (IDB).

Auer, Peter, Janine Berg and Ibrahim Coulibaly (2005), "Is a stable workforce good for productivity?", International Labour Review, vol. 144, No. 3.

Barreix, Alberto, Jerónimo Roca and Luiz Villela (eds.) (2006), La equidad fiscal en los paises andinos, Washington, D.C., Inter-American Development Bank (IDB)/Andean Community (CAN)/The Department for International Development (DFID).
Basombrío, Manuel (2009), "Estado e igualdad: del contrato social al pacto fiscal”, Macroeconomía del desarrollo series, No. 93 (LC/L.3099-P), Santiago, Chile, Economic Commission for Latin America and the Caribbean (ECLAC). United Nations publication, Sales No. S.09.II.G.81.

Beccaria, Luis and Fernando Groisman (2006), "Income instability, mobility and distribution in Argentina", CEPAL Review, No. 89 (LC/G.2312-P), Santiago, Chile, Economic Commission for Latin America and the Caribbean (ECLAC).

Behrman, Jere R., Nancy Birdsall and Miguel Szekely (2000), "Economic reform and wage differentials in Latin America", Research Department, Working Paper, No. 435, Washington, D.C., Inter-American Development Bank (IDB).

Calderón, César and Eduardo Levy Yeyati (2009), "Zooming in: from aggregate volatility to income distribution”, Policy Research Working Paper Series, No. 4895, Washington, D.C., World Bank.

Calderón-Madrid, Angel (2000), "Job stability and labor mobility in urban Mexico: a study based on duration models and transition analysis", Research Network Working Paper, No. R-419, Washington, D.C., InterAmerican Development Bank (IDB).

Castro Lugo, David and Luis Huesca Reynoso (2007), "Desigualdad salarial en México: una revisión", Papeles de población, Nueva época, vol. 13, No. 54, OctoberDecember.

Cetrángolo, Oscar (2007), "Búsqueda de cohesión social y sostenibilidad fiscal en los procesos de descentralización”, Politicas sociales series, No. 131 (LC/L.2700-P), Santiago, Chile, Economic Commission for Latin America and the Caribbean (ECLAC). United Nations publication, Sales No. S.07.II.G.50.

Cetrángolo, Oscar and Carlos Grushka (2004), "Sistema previsional argentino: crisis, reforma y crisis de la reforma", Financiamiento del desarrollo series, No. 151 (LC/L.2219-P), Santiago, Chile, Economic Commission for Latin America and the Caribbean (ECLAC). United Nations publication, Sales No. S.04.II.G.139.

Cetrángolo, Oscar and Juan Carlos Gómez-Sabaini (2007), "La tributación directa en América Latina y los desafíos a la imposición sobre la renta", Macroeconomía del desarrollo series, No. 60 (LC/L.2838-P), Santiago, Chile, Economic Commission for Latin America and the Caribbean (ECLAC). United Nations publication, Sales No. S.O7.II.G.159. 
Cetrángolo, Oscar and Juan Pablo Jiménez (2009), "Intergovernmental fiscal relations in Latin America: between regional disparities and fiscal sustainability", document presented at the Initiative for Policy Dialogue (IPD) Decentralization Task Force Meeting, New York 10-11 June.

Cetrángolo, Oscar, Ariela Goldschmit and Juan Pablo Jiménez (2009), "El financiamiento de políticas para la cohesión social y descentralización en América Latina" [online] http://www.urb-al3.eu/uploads/documentos/El_financiamiento_de_politicas_para_la_cohesion_social_y_descentralizacion_en_America_ Latina_CETRANGOLO_1.pdf.

Chang, Roberto, Linda Kaltani and Norman V. Loayza (2009), "Openness can be good for growth: The role of policy complementarities", Journal of Development Economics, vol. 90, No. 1, September.

Chu, Ke-young, Hamid Davoodi and Sanjeev Gupta (2000), "Income distribution and tax and government social spending policies in developing countries", IMF Working Paper, No. WP/00/62, Washington, D.C., International Monetary Fund (IMF).

Contreras, Dante and Sebastián Gallegos (2007), "Descomponiendo la desigualdad salarial en América Latina: ¿Una década de cambios?”, Estudios estadísticos y prospectivos series, No. 59 (LC/L.2789-P), Santiago, Chile, Economic Commission for Latin America and the Caribbean (ECLAC). Publicación de las Naciones Unidas, $\mathrm{N}^{\circ}$ de venta: S.0X.II.G.127.

Cortéz, Willy (2001), "What is behind increasing wage inequality in Mexico", World Development, vol. 29, No. 11.

Cowan, Kevin and Alejandro Micco (2005), "El seguro de desempleo en Chile: reformas pendientes", En foco, No. 53, Santiago, Chile, Expansiva.

Cowan, Kevin and others (2005), Un diagnóstico del desempleo en Chile, Santiago, Chile, University of Chile.

Cuadros, Jessica and Luis Felipe Jiménez (2004), "Inserción laboral desventajosa y desigualdades de cobertura previsional: la situación de las mujeres", Financiamiento del desarrollo series, No. 142 (LC/L.2070-P), Santiago, Chile, Economic Commission for Latin America and the Caribbean (ECLAC). United Nations publication, Sales No. S.04.II.G.13.

De Cesare, Claudia M. and José Francisco Lazo Marín (2008), "Impuestos a los patrimonios en América Latina", Macroeconomía del desarrollo series, No. 66 (LC/L.2902-P), Santiago, Chile, Economic Commission for Latin America and the Caribbean (ECLAC). United Nations publication, Sales No. S.08.II.G.38. de Ferranti, David and others (2002), From Natural Ressources to the Knowledge Economy. Trade and Job Quality, Washington, D.C., World Bank.

di Gropello, Emanuela and Rossella Cominetti (1998), La descentralización de la educación y la salud: un análisis comparativo de la experiencia latinoamericana (LC/L.1132), Santiago, Chile, Economic Commission for Latin America and the Caribbean (ECLAC).

ECLAC (Economic Commission for Latin America and the Caribbean) (2010a), Social Panorama of Latin America, 2009 (LC/G.2423-P), Santiago, Chile, Economic Commission for Latin America and the Caribbean (ECLAC). United Nations publication, Sales No. E.09.II.G.135.

_ (2010b), Time for equality: closing gaps, opening trails (LC/G.2432(SES.33/3)), Santiago, Chile.

_ (2008), Economic Survey of Latin America and the Caribbean, 2007-2008 (LC/G.2386-P), Santiago, Chile, Economic Commission for Latin America and the Caribbean (ECLAC). United Nations publication, Sales No. E.08.II.G.2.

—(2007), Social Panorama of Latin America, 2007 (LC/G.2351-P), Santiago, Chile, Economic Commission for Latin America and the Caribbean (ECLAC). United Nations publication, Sales No. E.07.II.G.124.

_(2006), Shaping the Future of Social Protection: Access, Financing and Solidarity (LC/G.2294(SES.31/3)), Santiago, Chile.

_ (2004), Productive Development in Open Economies (LC/G.2234(SES.30/3)), Santiago, Chile.

_ (1998), "The Fiscal Covenant. Strengths, Weaknesses, Challenges. Summary”, Libros de la CEPAL, No. 47 (LC/G.2024), Santiago, Chile.

ECLAC/ILO (Economic Commission for Latin America and the Caribbean/International Labour Organization) (2010), "Crisis, stabilization and reactivation: performance of the labour market in 2009", ECLAC/ ILO Bulletin The employment situation in Latin America and the Caribbean, No. 3, Santiago, Chile, June.

ECLAC/UNESCO (Economic Commission for Latin America and the Caribbean/United Nations Educational, Scientific and Cultural Organization) (2004), Financing and management of education in Latin America and the Caribbean: preliminary version (LC/G.2249(SES.30/14)), Santiago, Chile, June.

Farber, Henry S. (1999), "Mobility and stability: the dynamics of job change in labor markets", Handbook of Labor Economics, vol. 3.

Feenstra, Robert C. and Gordon H. Hanson (1997), "Foreign direct investment and relative wages: Evidence from Mexico's maquiladoras", Journal of International Economics, vol. 42. 
Freeman, Richard B. (2005), "La gran duplicación: los efectos de la globalización sobre los trabajadores en el mundo", Cambios globales y el mercado laboral peruano: comercio, legislación, capital humano y empleo, Lima, Universidad del Pacífico.

Freeman, Richard B. and Remco H. Oostendorp (2000), "Wages around the world: pay across occupations and countries", NBER Working Paper, No. 8058, Cambridge, Massachusetts.

Gaviria, Alejandro, Carlos Medina and María del Mar Palau (2007), "Las consecuencias económicas de un nombre atípico. El caso colombiano”, Documento CEDE, No. 2007/09.

Gómez Sabaini, Juan Carlos (2006), “Cohesión social, equidad y tributación. Análisis y perspectivas para América Latina", Políticas sociales series, No. 127 (LC/L.2641-P), Santiago, Chile, Economic Commission for Latin America and the Caribbean (ECLAC). United Nations publication, Sales No. S.06.II.G.167.

Gómez Sabaini, Juan Carlos and Juan O’Farrell (2009), "La economía política de la política tributaria en América Latina”, document presented at the twentyfirst Regional Seminar on Fiscal Policy, Economic Commission for Latin America and the Caribbean (ECLAC), Santiago, Chile, 26-29 January.

Gómez-Sabaini, Juan Carlos and Juan Pablo Jiménez (2009), The Role of Tax Policy in the Context of the Global Crisis: Consequences and Prospects (LC/L.3037), Santiago, Chile, Economic Commission for Latin America and the Caribbean (ECLAC).

Goñi, Edwin, J. Humberto López and Luis Servén (2008), "Fiscal redistribution and income inequality in Latin America", Policy Research Working Paper Series, No. 4487, World Bank.

Gutiérrez, Catalina and others (2007), "Does employment generation really matter for poverty reduction?", Policy Research Working Paper, No. 4432, Washington, D.C. IDB (Inter-American Development Bank) (2003), Good Jobs Wanted. Labour Markets in LatinAmerica, Washington, D.C.

Jaumotte, Florence, Subir Lall and Chris Papageorgiou (2008), "Rising income inequality: technology, or trade and financial globalization?", Working Paper, No. WP/08/185, Washington, D.C., International Monetary Fund (IMF).

Jiménez, Juan Pablo and Andrea Podestá (2009), "Las relaciones fiscales intergubernamentales y las finanzas subnacionales ante la crisis" (LC/R.2155), Santiago, Chile, Economic Commission for Latin America and the Caribbean (ECLAC).
Jiménez, Juan Pablo and Jesús Ruiz-Huerta (2009), Politica fiscal y equidad: una mirada cruzada entre Europa y América Latina (LC/R.2153), Santiago, Chile, Economic Commission for Latin America and the Caribbean (ECLAC).

Jiménez, Juan Pablo, Juan Carlos Gómez Sabaini and Andrea Podestá (2010), "Evasión y equidad en América Latina”, Project documents, No. 309 (LC/W.309/ Rev.1), Santiago, Chile, Economic Commission for Latin America and the Caribbean (ECLAC).

Jiménez, Luis and Jessica Cuadros (2003), “Evaluación de las reformas a los sistemas de pensiones: cuatro aspectos críticos y sugerencias de políticas", Financiamiento del desarrollo series, No. 131 (LC/L.1913-P), Santiago, Chile, Economic Commission for Latin America and the Caribbean (ECLAC). United Nations publication, Sales No. S.03.II.G.71.

Jorratt, Michael (2009), "La tributación directa en Chile: equidad y desafíos", Macroeconomía del desarrollo series, No. 92 (LC/L.3094-P), Santiago, Chile, Economic Commission for Latin America and the Caribbean (ECLAC). United Nations publication, Sales No. S.09. II.G.78.

Kacef, Osvaldo and Juan Pablo Jiménez (2010), "Volatilidad macro-fiscal y gobernabilidad democrática”, document presented at the Workshop on fiscal policy for democracy-building in Latin America, Economic Commission for Latin America and the Caribbean (ECLAC), Santiago, Chile, 27April.

Krusell, Per, Burhanettin Kuruscu and Anthony A. Smith (2002), "Equilibrium welfare and government policy with quasi-geometric discounting", Journal of Economic Theory, vol. 105, No. 1, July.

Lora, Eduardo and Mauricio Olivera (1998), "Macro policy and employment problems in Latin America”, Research Department Series, No. 4116, Washington, D.C., Inter-American Development Bank (IDB).

Medina, Fernando and Marco Galván (2008), "Descomposición del coeficiente de Gini por fuentes de ingreso: evidencia empírica para América Latina, 1999-2005”, Estudios estadisticos y prospectivos series, No. 63 (LC/ L.2911/E), Santiago, Chile, Economic Commission for Latin America and the Caribbean (ECLAC). United Nations publication, Sales No. S.08.II.G.45.

Mesa-Lago, Carmelo (2004), "Las reformas de pensiones en América Latina y su impacto en los principios de la seguridad social", Financiamiento del desarrollo series, No. 144 (LC/L.2090-P), Santiago, Chile, Economic Commission for Latin America and the Caribbean (ECLAC). United Nations publication, Sales No. S.04. II.G.29. 
Monsueto, Sandro Eduardo, Ana Flávia Machado and André Braz Golgher (2006), "Earning inequalities in Brazil: quantile regressions and the decomposition approach", CEPAL Review, No 90 (LC/G.2323-P), Santiago, Chile, Economic Commission for Latin America and the Caribbean (ECLAC).

Musgrave, Richard and Peggy Musgrave (1992), Hacienda pública teórica y aplicada, Madrid, McGraw Hill.

Nuñez, Javier and Roberto Gutiérrez (2004), "Classism, discrimination and meritocracy in the labor market: the case of Chile", Documento de trabajo, No. 208, Santiago, Chile, Department of Economics, Faculty of Economic and Administrative Sciences, University of Chile.

ILO (International Labour Organization) (2009), Labour Overview, 2009. Latin American and the Caribbean, Lima, Regional Office for Latin America and the Caribbean.

_(2008), Labour Overview, 2008. Latin America and the Caribbean, Lima, Regional Office for Latin America and the Caribbean.

Pagés, Carmen, Gaëlle Pierre and Stefano Scarpetta (2009), Job Creation in Latin America and the Caribbean. Recent Trends and Policy Challenges, Washington, D.C., Palgrave Macmillan/World Bank.

Pallage, S. and M.A. Robe (2001), "Foreign aid and the business cycle", Review of International Economics, vol. 9, No. 4.

Pavcnik, Nina and others (2002), “Trade liberalization and labor market adjustment in Brazil", Policy Research Working Paper, No. 2982, Washington, D.C., World Bank.

Perry, Guillermo E. and others (2006), Poverty Reduction and Growth: Virtuous and Vicious Circles, Washington, D.C., World Bank.

Prebisch, Raúl (1950), "Bases for the discussion of an anti-cyclical policy in Latin America", The Economic Development of Latin America and its Principal Problems (E/CN.12/89/Rev.l), New York. United Nations publication, Sales No. 50. II.G. 2.

Ramírez, Juan Mauricio and Liliana Núnéz (2000), "Reformas, crecimiento, progreso técnico y empleo en Colombia", Reformas económicas series, No. 59 (LC/L.1355/E), Santiago, Chile, Economic Commission for Latin America and the Caribbean (ECLAC).

Robbins, Donald (1996), "Evidence on trade and wages in the developing world", Technical Paper, No. 119, Paris, OECD Development Centre.

_(1994), "Relative wage structure in Chile, 1957-1992: changes in the structure of demand for schooling", Estudios de economía, vol. 21, special number.
Roca, Jerónimo (2009), “Tributación directa en Ecuador. Evasión, equidad y desafíos de diseño", Macroeconomía del desarrollo series, No. 85 (LC/L.3057-P), Santiago, Chile, Economic Commission for Latin America and the Caribbean (ECLAC). United Nations publication, Sales No. S.09.II.G.55.

Rodrigues Afonso, José Roberto (2004), “The relations between different levels of government in Brazil”, CEPAL Review, No. 84 (LC/G.2258-P), Santiago, Chile, Economic Commission for Latin America and the Caribbean (ECLAC).

Rodríguez Herrera, Adolfo and Fabio Durán Valverde (2000), "Los costos de la transición en un régimen de beneficio definido", Financiamiento del desarrollo series, No. 100 (LC/L.1405-P), Santiago, Chile, Economic Commission for Latin America and the Caribbean (ECLAC). United Nations publication, Sales No. S.00. II.G.74.

Rodríguez, Octavio (2006), El estructuralismo latinoamericano, Mexico City, Siglo Veintiuno/ Economic Commission for Latin America and the Caribbean (ECLAC).

Romaguera, Pilar and Sebastián Gallegos (2010), "Diagnóstico y recomendaciones al sistema de financiamiento de la educación en Chile", document presented in the workshop on distributive impact in public policies, Economic Commission for Latin America and the Caribbean (ECLAC), Santiago, Chile, 28-29 April.

Ros, Jaime (2006), "Patrones de especialización comercial y desempeño del mercado de trabajo en América Latina”, Macroeconomía del desarrollo series, No. 49 (LC/L.2566-P), Santiago, Chile, Economic Commission for Latin America and the Caribbean (ECLAC). United Nations publication, Sales No. S.06.II.G.94.

Sánchez-Páramo, Carolina and Norbert Schady (2003), "Off and running? Technolgy, trade, and the rising demand for skilled workers in Latin America”, Working Paper Series, No. 3015, World Bank.

Schneider, Friedrich and Dominik H. Enste (2000), "Shadow economies: size, causes, and consequences", Journal of Economic Literature, vol. 38, No. 1.

Simão, Anna Rosa Alux (2009), "Sistema de vigilancia e fiscalização do trabalho no Brasil: efeitos sobre a expansão do emprego formal no período 1999-2007", Mercado do trabalho, vol. 39.

SPTyEL (Subsecretaría de Programación Técnica y Estudios Laborales) (2005), “Trabajo, ocupación y empleo. Trayectorias, negociación colectiva e ingresos”, Estudios, No. 2, Buenos Aires. 
Tokman, Víctor E. (2006), "Inserción laboral, mercados de trabajo y protección social”, Financiamiento del desarrollo series, No. 170 (LC/L.2507-P), Santiago, Chile, Economic Commission for Latin America and the Caribbean (ECLAC). United Nations publication, Sales No. S.06.II.G.39.

Toledo, Manuel (2008), "Understanding business cycles in Latin America” [online] http://www.cepal.org/de/ agenda/9/35959/Presentacion_ppt_M.Toledo.pdf.

Torres Olivos, Miguel (2007), "Fernando Fajnzylber. Una visión renovadora de desarrollo en América Latina", Libros de la CEPAL, No. 92 (LC/G.2322-P), Santiago, Chile, Economic Commission for Latin America and the Caribbean (ECLAC). United Nations publication, Sales No. S.06.II.G.124.

UNESCO/OREALC (United Nations Educational, Scientific and Cultural Organization/UNESCO Regional Office for Education in Latin America and the Caribbean) (2008), The State of Education in Latin America and the Caribbean: guaranteeing quality education for all. Regional Review and Assessment Report on progress toward EFA (EFA/ PRELAC-2007), Santiago, Chile.

Uthoff, Andras (2010), "Impacto distributivo en las políticas públicas", document presented in the workshop on distributive impact in public policies, Economic Commission for Latin America and the Caribbean (ECLAC), Santiago, Chile, 28-29 April.

Velásquez, Mario (2010), "Seguros de desempleo y reformas recientes en América Latina", Macroeconomía del desarrollo series, No. 99 (LC/L.3144-P), Santiago, Chile, Economic Commission for Latin America and the Caribbean (ECLAC). United Nations publication, Sales No. S.09.II.G.117.

Villatoro, Pablo (2007), "Las transferencias condicionadas en América Latina: luces y sombras", document presented at the International seminar on conditional transfer programmes: the experiences of different countries, Economic Commission for Latin America and the Caribbean (ECLAC), Brasilia.

Weller, Jurgen (2010), "Contexto macro, empleo e impacto distributivo", document presented in the workshop on distributive impact in public policies, Economic Commission for Latin America and the Caribbean (ECLAC), Santiago, Chile, 28-29 April.

_ (2000), Reformas económicas, crecimiento los mercados de trabajo en América Latina y S eamntpialego, Chile, Economic Commission for Latin America and the Caribbean (ECLAC)/Fondo de Cultura Económica.
Willmore, Larry (2006), "Non-contributory pensions: Bolivia and Antigua in an international context", Financiamiento del desarrollo series, No. 167 (LC/ L.2481-P), Santiago, Chile, Economic Commission for Latin America and the Caribbean (ECLAC). United Nations publication, Sales No. E.06.II.G.12. 


\section{Statistical annex}

Table A-1

LATIN AMERICA AND THE CARIBBEAN: MAIN ECONOMIC INDICATORS

\begin{tabular}{|c|c|c|c|c|c|c|c|c|c|}
\hline & 2001 & 2002 & 2003 & 2004 & 2005 & 2006 & 2007 & 2008 & $2009^{a}$ \\
\hline & \multicolumn{9}{|c|}{ Annual growth rates } \\
\hline Gross domestic product ${ }^{b}$ & 0.3 & -0.3 & 2.2 & 6.1 & 4.9 & 5.8 & 5.8 & 4.2 & -1.9 \\
\hline Per capita gross domestic product ${ }^{b}$ & -1.0 & -1.7 & 0.9 & 4.7 & 3.6 & 4.5 & 4.7 & 3.0 & -3.0 \\
\hline \multirow[t]{2}{*}{ Consumer prices ${ }^{c}$} & 6.1 & 12.2 & 8.5 & 7.4 & 6.1 & 5.0 & 6.5 & 8.2 & 4.6 \\
\hline & \multicolumn{9}{|c|}{ Percentages } \\
\hline Urban open unemployment ${ }^{d}$ & 10.2 & 11.1 & 11.0 & 10.3 & 9.1 & 8.6 & 7.9 & 7.3 & 8.2 \\
\hline Total gross external debt/GDP e & 36.4 & 20.6 & 20.6 & 17.9 & 13.0 & 10.9 & 10.2 & 9.1 & 10.7 \\
\hline \multirow{3}{*}{$\begin{array}{l}\text { Total gross external debt/ } \\
\text { exports of goods and services }\end{array}$} & & & & & & & & & \\
\hline & 181 & 177 & 169 & 138 & 102 & 84 & 83 & 73 & 100 \\
\hline & \multicolumn{9}{|c|}{ Millions of dollars } \\
\hline \multicolumn{10}{|l|}{ Balance of payments ${ }^{f}$} \\
\hline Current account balance & -53929 & -16422 & 9264 & 22287 & 37086 & 50182 & 14871 & -27349 & -16412 \\
\hline Merchandise trade balance & -7416 & 20044 & 41375 & 56864 & 79057 & 97238 & 68254 & 43363 & 51976 \\
\hline Exports of goods f.o.b. & 354280 & 357746 & 390504 & 481277 & 580552 & 694321 & 779410 & 906316 & 701095 \\
\hline Imports of goods f.o.b. & 361696 & 337702 & 349130 & 424413 & 501496 & 597082 & 711155 & 862953 & 649118 \\
\hline Services trade balance & -16914 & -11973 & -10383 & -10576 & -14617 & -15861 & -22588 & -29655 & -29539 \\
\hline Income balance & -56095 & -54420 & -59744 & -69357 & -80708 & -95246 & -97859 & -108036 & -99344 \\
\hline Net current transfers & 26496 & 29927 & 38016 & 45356 & 53355 & 64051 & 67072 & 66978 & 60495 \\
\hline Capital and financial balance ${ }^{g}$ & 38295 & -9410 & 1593 & -8434 & 21539 & 11231 & 110482 & 65577 & 61375 \\
\hline Net foreign direct investment & 66122 & 50504 & 37806 & 49745 & 54703 & 31192 & 90214 & 94731 & 64621 \\
\hline Other capital movements & -27827 & -59913 & -36214 & -58178 & -33164 & -19961 & 20268 & -29154 & -3246 \\
\hline Overall balance & -15634 & -25832 & 10856 & 13854 & 58626 & 61413 & 125353 & 38228 & 44962 \\
\hline Variation in reserve assets ${ }^{h}$ & -614 & 3421 & -29486 & -22711 & -37256 & -48734 & -127281 & -41866 & -52299 \\
\hline Other financing & -15021 & -29253 & 40343 & 36565 & 95882 & 110147 & 252634 & 80094 & 97261 \\
\hline Net transfer of resources & -1552 & -41419 & -39521 & -68933 & -80539 & -96694 & 14551 & -38821 & -30636 \\
\hline International reserves ${ }^{\dagger}$ & 163177 & 164784 & 197615 & 225668 & 262168 & 319045 & 459152 & 512240 & 566961 \\
\hline
\end{tabular}

Fiscal sector ${ }^{\mathrm{i}}$

Overall balance

Primary balance

Total revenue

Tax revenue

Total expenditure

Capital expenditure

Central-government public debt

$\begin{array}{llllll}177 & 164784 & 197615 & 225668 & 262168 & 319\end{array}$

Public debt of the non-financial public-sector (NFPS)

$\begin{array}{rrrrrrrrr}-3.1 & -2.9 & -3.0 & -1.9 & -1.1 & 0.0 & 0.3 & -0.4 & -2.8 \\ -0.8 & -0.5 & -0.2 & 0.5 & 1.3 & 2.2 & 2.2 & 1.2 & -1.0 \\ 16.4 & 16.5 & 16.6 & 17.0 & 18.0 & 18.9 & 19.5 & 19.6 & 18.4 \\ 12.8 & 12.9 & 13.0 & 13.5 & 14.3 & 14.6 & 15.1 & 15.0 & 14.6 \\ 19.5 & 19.4 & 19.5 & 18.8 & 19.1 & 19.0 & 19.2 & 20.0 & 21.2 \\ 3.6 & 3.5 & 3.6 & 3.5 & 3.5 & 3.5 & 3.9 & 4.3 & 4.2 \\ 44.9 & 58.2 & 57.3 & 50.9 & 42.8 & 35.8 & 29.9 & 28.2 & 30.2 \\ 48.5 & 62.7 & 61.4 & 54.2 & 46.5 & 39.6 & 33.6 & 31.6 & 33.2\end{array}$

Source: Economic Commission for Latin America and the Caribbean (ECLAC), on the basis of official figures.

a Preliminary figures.

Based on official figures expressed in 2000 dollars.

December - December variation.

The data for Argentina and Brazil have been adjusted to allow for changes in methodology in 2003 and 2002, respectively.

Estimates based on figures denominated in dollars at current prices. Does not include Cuba.

Does not include Cuba.

g Includes errors and omissions.

h A minus sign (-) indicates an increase in reserve assets.

Central government, except for the Plurinational State of Bolivia, where coverage corresponds to general government. Simple averages. Includes information from 19

Latin American and Caribbean countries: Argentina, Bolivarian Republic of Venezuela, Brazil, Chile, Colombia, Costa Rica, Dominican Republic, Ecuador,

El Salvador, Guatemala, Haiti, Honduras, Mexico, Nicaragua, Panama, Paraguay, Peru, Plurinational State of Bolivia and Uruguay. 
Table A-2

LATIN AMERICA AND THE CARIBBEAN: GROSS DOMESTIC PRODUCT

(Millions of current dollars)

\begin{tabular}{|c|c|c|c|c|c|c|c|c|c|}
\hline & 2001 & 2002 & 2003 & 2004 & 2005 & 2006 & 2007 & 2008 & $2009^{a}$ \\
\hline Latin America and the Caribbean & 2065612 & 1854071 & 1922188 & 2218565 & 2688411 & 3164231 & 3726380 & 4328416 & 4023 \\
\hline Antigua and Barbuda & 696 & 713 & 753 & 815 & 867 & 1011 & 1155 & 1203 & 1098 \\
\hline Argentina & 268831 & 102042 & 129596 & 153129 & 183196 & 214267 & 262451 & 328469 & 308740 \\
\hline Bahamas & 5659 & 5912 & 5942 & 6189 & 6797 & 7280 & 7498 & 7564 & 7421 \\
\hline Barbados & 2554 & 2476 & 2695 & 2817 & 3006 & 3191 & 3452 & 3541 & 3538 \\
\hline Belize & 872 & 933 & 988 & 1056 & 1115 & 1213 & 1277 & 1359 & 1331 \\
\hline Bolivia (Plurinational State of) & 8142 & 7905 & 8082 & 8773 & 9549 & 11452 & 13120 & 16674 & 17340 \\
\hline Brazil & 554188 & 506041 & 552383 & 663733 & 882044 & 1089397 & 1366853 & 1638636 & 1574 \\
\hline Chile & 68840 & 67532 & 73990 & 95653 & 118250 & 146774 & 164317 & 170850 & 163305 \\
\hline Colombia $^{\text {b }}$ & 98752 & 98375 & 94911 & 117148 & 146605 & 162912 & 207369 & 242400 & 232910 \\
\hline Costa Rica & 16404 & 16844 & 17518 & 18595 & 19965 & 22526 & 26322 & 29848 & 29303 \\
\hline Cuba & 31682 & 33591 & 35901 & 38203 & 42644 & 52743 & 58604 & 60806 & 62279 \\
\hline Dominica & 266 & 255 & 263 & 285 & 299 & 316 & 344 & 374 & 378 \\
\hline Ecuador & 21271 & 24718 & 28409 & 32646 & 36942 & 41705 & 45504 & 54209 & 52022 \\
\hline El Salvador & 13813 & 14307 & 15047 & 15798 & 17214 & 18749 & 20377 & 22107 & 21101 \\
\hline Grenada & 422 & 437 & 480 & 469 & 554 & 564 & 610 & 678 & 615 \\
\hline Guatemala & 18703 & 20777 & 21918 & 23965 & 27211 & 30231 & 34113 & 39139 & 37322 \\
\hline Guyana & 1136 & 1158 & 1185 & 1256 & 1315 & 1458 & 1740 & 1923 & 2026 \\
\hline Haiti & 3508 & 3215 & 2827 & 3660 & 4154 & 4880 & 5971 & 6408 & 6511 \\
\hline Honduras & 7653 & 7860 & 8234 & 8871 & 9757 & 10917 & 12392 & 13969 & 14318 \\
\hline Jamaica & 9104 & 9677 & 9399 & 10135 & 11165 & 11957 & 12908 & 13995 & 12313 \\
\hline Mexico & 681762 & 711103 & 700325 & 758577 & 846094 & 949330 & 1022830 & 1086 & 872087 \\
\hline Nicaragua & 4125 & 4026 & 4102 & 4465 & 4872 & 5230 & 5599 & 6248 & 6149 \\
\hline Panama & 11807 & 12272 & 12933 & 14179 & 15465 & 17137 & 19794 & 23184 & 24315 \\
\hline Paraguay & 6446 & 5092 & 5552 & 6950 & 7473 & 9275 & 12222 & 16873 & 14240 \\
\hline Peru & 53955 & 56775 & 61356 & 69701 & 79389 & 92319 & 107524 & 129107 & 130355 \\
\hline Dominican Republic & 24512 & 24913 & 20045 & 21582 & 33542 & 35660 & 41013 & 45523 & 46598 \\
\hline Saint Kitts and Nevis & 342 & 351 & 362 & 400 & 439 & 487 & 513 & 570 & 545 \\
\hline Saint Vincent and the Grenadines & 349 & 370 & 387 & 421 & 446 & 498 & 554 & 582 & 585 \\
\hline Saint Lucia & 687 & 700 & 738 & 799 & 858 & 931 & 958 & 986 & 946 \\
\hline Suriname & 665 & 955 & 1122 & 1114 & 1376 & 1610 & 1850 & 2305 & 2192 \\
\hline Trinidad and Tobago & 8825 & 9008 & 11305 & 13280 & 15982 & 18369 & 20904 & 25968 & 21125 \\
\hline Uruguay & 19036 & 12591 & 11477 & 13555 & 17040 & 19802 & 23952 & 31178 & 31511 \\
\hline Venezuela (Bolivarian Republic of) & 120605 & 91147 & 81963 & 110343 & 142785 & 180037 & 222289 & 305296 & 325399 \\
\hline
\end{tabular}

Source:Economic Commission for Latin America and the Caribbean (ECLAC), on the basis of official figures.

a Preliminary figures.

b Based in the new quarterly national accounts figures published by the country, base year 2005 . 
Table A-3

LATIN AMERICA AND THE CARIBBEAN: GROSS DOMESTIC PRODUCT (Annual growth rates)

\begin{tabular}{|c|c|c|c|c|c|c|c|c|c|}
\hline & 2001 & 2002 & 2003 & 2004 & 2005 & 2006 & 2007 & 2008 & $2009^{a}$ \\
\hline Latin America and the Caribbean ${ }^{b}$ & 0.3 & -0.4 & 2.2 & 6.1 & 4.9 & 5.8 & 5.8 & 4.2 & -1.9 \\
\hline Antigua and Barbuda & 2.0 & 2.5 & 5.2 & 7.0 & 4.2 & 13.3 & 9.1 & 0.2 & -10.9 \\
\hline Argentina & -4.4 & -10.9 & 8.8 & 9.0 & 9.2 & 8.5 & 8.7 & 6.8 & 0.9 \\
\hline Bahamas & -0.6 & 2.2 & 0.7 & 1.6 & 5.0 & 3.5 & 1.9 & -1.7 & -4.3 \\
\hline Barbados & -4.6 & 0.7 & 1.9 & 4.8 & 3.9 & 3.2 & 3.4 & 0.5 & -3.6 \\
\hline Belize & 5.0 & 5.1 & 9.3 & 4.6 & 3.0 & 4.7 & 1.2 & 3.8 & -0.0 \\
\hline Bolivia (Plurinational State of) & 1.7 & 2.5 & 2.7 & 4.2 & 4.4 & 4.8 & 4.6 & 6.1 & 3.4 \\
\hline Brazil & 1.3 & 2.7 & 1.1 & 5.7 & 3.2 & 4.0 & 6.1 & 5.1 & -0.2 \\
\hline Chile & 3.4 & 2.2 & 3.9 & 6.0 & 5.6 & 4.6 & 4.6 & 3.7 & -1.5 \\
\hline Colombia $^{\mathrm{c}}$ & 1.8 & 2.5 & 3.9 & 5.3 & 5.0 & 7.1 & 6.3 & 2.7 & 0.8 \\
\hline Costa Rica & 1.1 & 2.9 & 6.4 & 4.3 & 5.9 & 8.8 & 7.9 & 2.8 & -1.1 \\
\hline Cuba & 3.2 & 1.4 & 3.8 & 5.8 & 11.2 & 12.1 & 7.3 & 4.1 & 1.4 \\
\hline Dominica & -3.8 & -4.0 & 2.2 & 6.3 & 3.4 & 6.3 & 4.9 & 3.5 & -0.9 \\
\hline Ecuador & 4.8 & 3.4 & 3.3 & 8.8 & 5.7 & 4.8 & 2.0 & 7.2 & 0.4 \\
\hline El Salvador & 1.7 & 2.3 & 2.3 & 1.9 & 3.3 & 4.2 & 4.3 & 2.4 & -3.5 \\
\hline Grenada & -3.9 & 2.1 & 8.4 & -6.5 & 12.0 & -1.9 & 4.5 & 0.9 & -8.3 \\
\hline Guatemala & 2.3 & 3.9 & 2.5 & 3.2 & 3.3 & 5.4 & 6.3 & 3.3 & 0.6 \\
\hline Guyana & 1.6 & 1.1 & -0.6 & 1.6 & -2.0 & 5.1 & 7.0 & 2.0 & 3.3 \\
\hline Haiti & -1.0 & -0.3 & 0.4 & -3.5 & 1.8 & 2.3 & 3.3 & 0.8 & 2.9 \\
\hline Honduras & 2.7 & 3.8 & 4.5 & 6.2 & 6.1 & 6.6 & 6.3 & 4.0 & -1.9 \\
\hline Jamaica & 1.3 & 1.0 & 3.5 & 1.4 & 1.0 & 2.7 & 1.5 & -0.9 & -2.7 \\
\hline Mexico & -0.0 & 0.8 & 1.4 & 4.1 & 3.3 & 4.8 & 3.4 & 1.5 & -6.5 \\
\hline Nicaragua & 3.0 & 0.8 & 2.5 & 5.3 & 4.3 & 4.2 & 3.1 & 2.8 & -1.5 \\
\hline Panama & 0.6 & 2.2 & 4.2 & 7.5 & 7.2 & 8.5 & 12.1 & 10.7 & 2.4 \\
\hline Paraguay & 2.1 & -0.0 & 3.8 & 4.1 & 2.9 & 4.3 & 6.8 & 5.8 & -3.8 \\
\hline Peru & 0.2 & 5.0 & 4.0 & 5.0 & 6.8 & 7.7 & 8.9 & 9.8 & 0.9 \\
\hline Dominican Republic & 1.8 & 5.8 & -0.3 & 1.3 & 9.3 & 10.7 & 8.5 & 5.3 & 3.5 \\
\hline Saint Kitts and Nevis & 2.0 & 1.0 & 0.5 & 7.6 & 5.6 & 5.5 & 2.0 & 4.6 & -11.1 \\
\hline Saint Vincent and the Grenadines & 2.2 & 3.8 & 3.1 & 6.6 & 2.1 & 9.5 & 8.6 & 1.3 & -2.8 \\
\hline Saint Lucia & -5.9 & 2.0 & 4.1 & 5.6 & 4.3 & 5.9 & 2.2 & 0.8 & -4.6 \\
\hline Suriname & 5.7 & 2.7 & 6.8 & 0.5 & 7.2 & 3.9 & 5.1 & 4.3 & 2.2 \\
\hline Trinidad and Tobago & 4.2 & 7.9 & 14.4 & 8.0 & 5.4 & 14.4 & 4.6 & 2.3 & -0.9 \\
\hline Uruguay & -3.4 & -11.0 & 2.2 & 11.8 & 6.6 & 7.0 & 7.5 & 8.5 & 2.9 \\
\hline Venezuela (Bolivarian Republic of) & 3.4 & -8.9 & -7.8 & 18.3 & 10.3 & 9.9 & 8.2 & 4.8 & -3.3 \\
\hline
\end{tabular}

Source:Economic Commission for Latin America and the Caribbean (ECLAC), on the basis of official figures.

Preliminary figures.

Based on official figures expressed in 2000 dollars.

Based in the new quarterly national accounts figures published by the country, base year 2005 . 
Table A-4

LATIN AMERICA AND THE CARIBBEAN: PER CAPITA GROSS DOMESTIC PRODUCT (Annual growth rates)

\begin{tabular}{|c|c|c|c|c|c|c|c|c|c|}
\hline & 2001 & 2002 & 2003 & 2004 & 2005 & 2006 & 2007 & 2008 & $2009^{a}$ \\
\hline Latin America and the Caribbean ${ }^{b}$ & -1.0 & -1.7 & 0.9 & 4.7 & 3.6 & 4.5 & 4.7 & 3.0 & -3.0 \\
\hline Antigua and Barbuda & -0.5 & 1.3 & 3.9 & 5.7 & 1.7 & 11.9 & 7.8 & -1.0 & -11.9 \\
\hline Argentina & -5.4 & -11.8 & 7.8 & 8.0 & 8.1 & 7.4 & 7.6 & 5.7 & -0.2 \\
\hline Bahamas & -1.9 & 0.9 & -0.6 & 0.3 & 3.8 & 1.9 & 0.7 & -2.8 & -5.4 \\
\hline Barbados & -4.2 & 0.7 & 1.5 & 4.4 & 3.9 & 2.8 & 3.0 & 0.5 & -4.0 \\
\hline Belize & 2.5 & 2.7 & 6.9 & 2.3 & 0.8 & 2.5 & -1.2 & 1.7 & -2.0 \\
\hline Bolivia (Plurinational State of) & -0.4 & 0.4 & 0.7 & 2.2 & 2.5 & 2.9 & 2.7 & 4.3 & 1.6 \\
\hline Brazil & -0.1 & 1.2 & -0.2 & 4.4 & 1.9 & 2.8 & 5.0 & 4.1 & -1.1 \\
\hline Chile & 2.2 & 1.0 & 2.8 & 4.9 & 4.5 & 3.5 & 3.5 & 2.6 & -2.5 \\
\hline Colombia $^{c}$ & 0.1 & 0.9 & 2.3 & 3.7 & 3.4 & 5.5 & 4.7 & 1.2 & -0.6 \\
\hline Costa Rica & -1.0 & 0.8 & 4.3 & 2.4 & 4.1 & 7.1 & 6.4 & 1.5 & -2.3 \\
\hline Cuba & 2.9 & 1.2 & 3.6 & 5.6 & 11.1 & 12.0 & 7.2 & 4.1 & 1.4 \\
\hline Dominica & -3.8 & -4.0 & 2.2 & 6.3 & 4.9 & 6.3 & 4.9 & 3.5 & -0.9 \\
\hline Ecuador & 3.4 & 2.2 & 2.1 & 7.6 & 4.6 & 3.6 & 1.0 & 6.1 & -0.7 \\
\hline El Salvador & 1.2 & 1.9 & 2.0 & 1.5 & 2.9 & 3.8 & 3.9 & 2.0 & -4.0 \\
\hline Grenada & -3.9 & 1.1 & 8.4 & -6.5 & 11.0 & -1.9 & 4.5 & -0.1 & -8.3 \\
\hline Guatemala & -0.1 & 1.3 & 0.0 & 0.6 & 0.7 & 2.8 & 3.7 & 0.8 & -1.9 \\
\hline Guyana & 1.5 & 0.9 & -0.9 & 1.3 & -2.1 & 5.1 & 7.0 & 2.1 & 3.5 \\
\hline Haiti & -2.7 & -1.8 & -1.2 & -5.0 & 0.2 & 0.6 & 1.7 & -0.8 & 1.2 \\
\hline Honduras & 0.6 & 1.7 & 2.5 & 4.1 & 3.9 & 4.4 & 4.2 & 1.9 & -3.8 \\
\hline Jamaica & 0.5 & 0.2 & 2.7 & 0.7 & 0.3 & 2.1 & 1.0 & -1.4 & -3.1 \\
\hline Mexico & -1.3 & -0.5 & 0.2 & 2.9 & 2.1 & 3.7 & 2.3 & 0.5 & -7.5 \\
\hline Nicaragua & 1.4 & -0.6 & 1.2 & 4.0 & 2.9 & 2.8 & 1.7 & 1.4 & -2.7 \\
\hline Panama & -1.3 & 0.4 & 2.3 & 5.6 & 5.3 & 6.7 & 10.2 & 8.9 & 0.8 \\
\hline Paraguay & -0.0 & -2.0 & 1.8 & 2.1 & 0.9 & 2.4 & 4.8 & 3.9 & -5.5 \\
\hline Peru & -1.2 & 3.6 & 2.6 & 3.6 & 5.5 & 6.4 & 7.6 & 8.5 & -0.3 \\
\hline Dominican Republic & 0.2 & 4.2 & -1.8 & -0.2 & 7.7 & 9.1 & 6.9 & 3.8 & 2.1 \\
\hline Saint Kitts and Nevis & -0.1 & 1.0 & -1.6 & 5.4 & 5.6 & 3.4 & 2.0 & 2.6 & -12.8 \\
\hline Saint Vincent and the Grenadines & 2.2 & 3.8 & 3.1 & 5.6 & 2.1 & 9.5 & 8.6 & 1.3 & -2.8 \\
\hline Saint Lucia & -7.1 & 1.4 & 2.8 & 4.3 & 3.7 & 4.6 & 0.9 & 0.3 & -5.8 \\
\hline Suriname & 4.2 & 1.2 & 5.5 & -0.9 & 5.9 & 2.8 & 4.1 & 3.3 & 1.2 \\
\hline Trinidad and Tobago & 3.8 & 7.5 & 14.1 & 7.5 & 5.1 & 14.0 & 4.2 & 1.9 & -1.3 \\
\hline Uruguay & -3.6 & -11.0 & 2.2 & 11.9 & 6.6 & 6.8 & 7.2 & 8.2 & 2.5 \\
\hline Venezuela (Bolivarian Republic of) & 1.5 & -10.5 & -9.4 & 16.2 & 8.4 & 8.0 & 6.3 & 3.0 & -4.9 \\
\hline
\end{tabular}

Source: Economic Commission for Latin America and the Caribbean (ECLAC), on the basis of official figures.

Preliminary figures.

Based on official figures expressed in 2000 dollars.

Based in the new quarterly national accounts figures published by the country, base year 2005 
Table A-5

LATIN AMERICA AND THE CARIBBEAN: COMPONENTS OF TOTAL DEMAND ${ }^{a}$

(Indices 2000=100)

\begin{tabular}{|c|c|c|c|c|c|c|c|c|c|}
\hline & 2001 & 2002 & 2003 & 2004 & 2005 & 2006 & 2007 & 2008 & $2009^{b}$ \\
\hline Total supply & 100.8 & 99.3 & 100.4 & 108.0 & 115.1 & 123.3 & 132.3 & 139.0 & 132.5 \\
\hline Gross domestic product & 100.3 & 99.9 & 102.1 & 108.3 & 113.7 & 120.2 & 127.4 & 132.8 & 130.3 \\
\hline Imports of goods and services & 99.9 & 94.3 & 95.6 & 109.3 & 122.1 & 139.7 & 157.4 & 170.5 & 144.2 \\
\hline Total demand & 100.8 & 99.3 & 100.4 & 108.0 & 115.1 & 123.3 & 132.3 & 139.0 & 132.5 \\
\hline Total consumption Private & 101.0 & 100.7 & 102.6 & 107.8 & 113.9 & 120.7 & 128.5 & 134.3 & 134.6 \\
\hline consumption Government & 100.9 & 100.2 & 102.1 & 107.9 & 114.3 & 121.6 & 129.8 & 136.1 & 135.3 \\
\hline consumption Gross capital & 101.2 & 102.9 & 104.6 & 107.8 & 112.3 & 116.5 & 122.7 & 126.0 & 131.1 \\
\hline formation Gross fixed capital & 101.0 & 91.6 & 86.9 & 98.2 & 106.8 & 119.5 & 133.4 & 147.9 & 124.6 \\
\hline formation Domestic demand & 97.2 & 90.8 & 90.7 & 102.2 & 113.9 & 128.7 & 144.7 & 157.2 & 142.1 \\
\hline \multirow[t]{2}{*}{ Exports of goods and services } & 101.0 & 98.8 & 99.3 & 105.8 & 112.4 & 120.4 & 129.5 & 137.1 & 132.5 \\
\hline & 100.0 & 102.1 & 106.2 & 119.2 & 128.8 & 138.3 & 146.5 & 148.5 & 132.7 \\
\hline
\end{tabular}

Source: Economic Commission for Latin America and the Caribbean (ECLAC), on the basis of official figures.

Based on official figures expressed in 2000 dollars. Includes information on 20 countries of Latin America and the Caribbean: Argentina, Bolivarian Republic of Venezuela, Brazil, Chile, Colombia, Costa Rica, Cuba, Dominican Republic, Ecuador, El Salvador, Guatemala, Haiti, Honduras, Mexico, Nicaragua, Panama, Paraguay, Peru, Plurinationa State of Bolivia and Uruguay.

b Preliminary figures.

Table A-6

LATIN AMERICA AND THE CARIBBEAN: GROSS DOMESTIC PRODUCT BY ECONOMIC SECTOR a (Indices 2000=100)

\begin{tabular}{|c|c|c|c|c|c|c|c|c|c|}
\hline & 2001 & 2002 & 2003 & 2004 & 2005 & 2006 & 2007 & 2008 & 2009 \\
\hline Gross domestic product at market prices & 100.4 & 100.0 & 102.2 & 108.4 & 113.8 & 120.4 & 127.5 & 132.8 & 130.3 \\
\hline Agriculture, livestock, forestry, hunting and fishing & 104.0 & 106.7 & 111.5 & 114.0 & 116.7 & 121.5 & 127.8 & 131.8 & 128.1 \\
\hline Mining and quarrying & 102.1 & 100.6 & 104.6 & 109.2 & 111.3 & 114.0 & 113.8 & 115.0 & 114.1 \\
\hline Manufacturing & 97.5 & 96.1 & 98.3 & 105.6 & 109.9 & 115.4 & 121.0 & 123.4 & 115.4 \\
\hline Construction & 97.2 & 93.6 & 93.9 & 102.3 & 109.9 & 121.8 & 129.8 & 135.5 & 130.1 \\
\hline Electricity, gas, water and sanitation services & 98.8 & 100.6 & 104.0 & 109.9 & 114.2 & 120.4 & 124.6 & 127.8 & 128.4 \\
\hline Transport, storage and communications & 102.8 & 104.3 & 108.1 & 116.7 & 125.4 & 135.2 & 147.0 & 156.6 & 155.8 \\
\hline Wholesale and retail trade, restaurants and hotels & 98.9 & 96.6 & 99.0 & 106.3 & 112.4 & 120.6 & 128.2 & 133.8 & 125.9 \\
\hline \multicolumn{10}{|l|}{ Financial establishments, insurance, real estate } \\
\hline and business services & 102.4 & 104.0 & 105.8 & 110.6 & 117.0 & 124.4 & 133.7 & 142.0 & 142.6 \\
\hline Community, social and personal services & 101.0 & 102.7 & 104.4 & 108.5 & 113.1 & 117.6 & 122.5 & 126.5 & 130.3 \\
\hline
\end{tabular}

Source: Economic Commission for Latin America and the Caribbean (ECLAC), on the basis of official figures.

a Based on official figures expressed in 2000 dollars. Includes information on 33 countries of Latin America and the Caribbean: Antigua and Barbuda, Argentina, Barbados, Belize, Bolivarian Republic of Venezuela, Brazil, Chile, Colombia, Costa Rica, Cuba, Dominica, Dominican Republic, Ecuador, El Salvador, Grenada, Guatemala, Guyana, Haiti, Honduras, Jamaica, Mexico, Nicaragua, Panama, Paraguay, Plurinational State of Bolivia, Peru, Saint Kitts and Nevis, Saint Lucia, Saint Vincent and the Grenadines, Surinam, The Bahamas, Trinidad and Tobago and Uruguay.

b Preliminary figures. 
Table A-7

LATIN AMERICA AND THE CARIBBEAN: GROSS FIXED CAPITAL FORMATION

(Percentages of GDP)

\begin{tabular}{|c|c|c|c|c|c|c|c|c|c|}
\hline & 2001 & 2002 & 2003 & 2004 & 2005 & 2006 & 2007 & 2008 & $2009^{b}$ \\
\hline Latin America and the Caribbean & 18.0 & 16.8 & 16.5 & 17.5 & 18.6 & 19.8 & 21.0 & 21.9 & 20.2 \\
\hline Argentina & 14.3 & 10.2 & 12.9 & 15.9 & 17.9 & 19.5 & 20.4 & 20.9 & 18.6 \\
\hline Bahamas & 28.4 & 26.5 & 26.9 & 24.8 & 30.0 & 35.8 & 35.8 & 30.6 & 30.0 \\
\hline Belize & 25.6 & 23.1 & 18.1 & 16.4 & 17.2 & 16.7 & 17.4 & 22.9 & 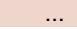 \\
\hline Bolivia (Plurinational State of) & 13.8 & 16.0 & 13.9 & 13.2 & 13.4 & 14.0 & 15.1 & 16.9 & 16.8 \\
\hline Brazil & 16.6 & 15.4 & 14.5 & 15.0 & 15.0 & 15.9 & 17.0 & 18.4 & 16.6 \\
\hline Chile & 19.9 & 19.8 & 20.2 & 20.9 & 24.5 & 24.0 & 25.5 & 29.2 & 25.1 \\
\hline Colombia & 14.0 & 14.7 & 16.0 & 17.4 & 19.9 & 21.8 & 23.4 & 23.9 & 23.4 \\
\hline Costa Rica & 18.0 & 18.7 & 18.8 & 18.0 & 17.7 & 18.0 & 19.7 & 21.1 & 18.7 \\
\hline Cuba & 11.2 & 10.0 & 9.0 & 9.2 & 9.9 & 12.8 & 12.2 & 12.6 & 10.5 \\
\hline Ecuador & 23.6 & 27.2 & 26.3 & 25.3 & 26.6 & 26.3 & 26.4 & 28.6 & 27.3 \\
\hline El Salvador & 16.9 & 17.1 & 17.1 & 15.9 & 15.7 & 17.0 & 16.8 & 15.6 & 13.3 \\
\hline Guatemala & 19.0 & 20.0 & 18.9 & 18.1 & 18.3 & 20.1 & 19.8 & 18.0 & 16.6 \\
\hline Haiti & 27.3 & 28.0 & 28.8 & 28.9 & 28.8 & 28.8 & 28.7 & 29.3 & 29.4 \\
\hline Honduras & 24.3 & 21.7 & 22.1 & 25.7 & 23.8 & 25.4 & 29.4 & 29.5 & 20.3 \\
\hline Mexico & 20.2 & 19.9 & 19.7 & 20.5 & 21.3 & 22.3 & 23.1 & 23.7 & 22.8 \\
\hline Nicaragua & 26.4 & 24.5 & 24.1 & 24.4 & 25.7 & 25.2 & 25.3 & 26.0 & 22.2 \\
\hline Panama & 15.7 & 14.4 & 17.1 & 17.4 & 17.3 & 18.6 & 23.3 & 26.4 & 27.2 \\
\hline Paraguay & 16.1 & 15.0 & 15.5 & 15.6 & 16.4 & 16.2 & 17.3 & 19.3 & 17.2 \\
\hline Peru & 18.5 & 17.5 & 17.8 & 18.3 & 19.2 & 21.2 & 24.0 & 28.8 & 26.2 \\
\hline Dominican Republic & 19.3 & 19.1 & 15.3 & 14.8 & 15.4 & 16.9 & 17.5 & 18.2 & 14.9 \\
\hline Trinidad and Tobago & 23.0 & 18.7 & 26.2 & 21.8 & 31.8 & 16.6 & 15.5 & 16.5 & $\ldots$ \\
\hline Uruguay & 15.8 & 12.0 & 10.4 & 12.1 & 13.4 & 15.7 & 15.9 & 17.4 & 16.3 \\
\hline Venezuela (Bolivarian Republic of) & 23.1 & 20.7 & 14.1 & 17.9 & 22.4 & 26.4 & 30.6 & 28.3 & 26.9 \\
\hline
\end{tabular}

Source: Economic Commission for Latin America and the Caribbean (ECLAC), on the basis of official figures.

a On the basis of figures expressed in constant 2000 dollars.

b Preliminary figures.

Table A-8

LATIN AMERICA AND THE CARIBBEAN: FINANCING OF GROSS DOMESTIC INVESTMENT ${ }^{a}$

(Percentages of GDP)

\begin{tabular}{|c|c|c|c|c|c|c|c|c|c|c|c|c|}
\hline & \multicolumn{4}{|c|}{ Gross domestic investment } & \multicolumn{4}{|c|}{ National saving } & \multicolumn{4}{|c|}{ External saving } \\
\hline & 2006 & 2007 & 2008 & $2009 b$ & 2006 & 2007 & 2008 & $2009^{b}$ & 2006 & 2007 & 2008 & $2009^{b}$ \\
\hline Latin America and the Caribbean & 21.5 & 22.1 & 23.4 & 19.6 & 23.0 & 22.5 & 22.7 & 19.3 & -1.5 & -0.4 & 0.7 & 0.4 \\
\hline Argentina & 23.0 & 24.2 & 25.1 & 21.2 & 26.7 & 27.0 & 27.3 & 24.9 & -3.6 & -2.8 & -2.2 & -3.7 \\
\hline Bolivia (Plurinational State of) & 13.9 & 15.2 & 17.6 & 17.0 & 25.4 & 27.3 & 29.6 & 21.6 & -11.5 & -12.1 & -12.1 & -4.6 \\
\hline Brazil & 16.8 & 18.3 & 19.9 & 16.5 & 18.0 & 18.4 & 18.2 & 15.0 & -1.3 & -0.1 & 1.7 & 1.5 \\
\hline Chile & 20.1 & 20.5 & 25.1 & 19.0 & 24.9 & 25.0 & 23.6 & 21.6 & -4.9 & -4.5 & 1.5 & -2.6 \\
\hline Colombia & 24.3 & 24.3 & 25.0 & 24.2 & 22.5 & 21.5 & 22.3 & 22.0 & 1.8 & 2.8 & 2.8 & 2.2 \\
\hline Costa Rica & 26.4 & 24.7 & 27.5 & 13.8 & 21.9 & 18.4 & 18.3 & 11.6 & 4.5 & 6.3 & 9.2 & 2.2 \\
\hline Cuba & 11.7 & 10.2 & 14.8 & 10.3 & 11.3 & 11.0 & 14.8 & 10.3 & 0.4 & -0.8 & $\ldots$ & \\
\hline Ecuador & 23.8 & 24.3 & 27.9 & 23.3 & 27.4 & 27.8 & 29.7 & 22.7 & -3.6 & -3.5 & -1.8 & 0.6 \\
\hline El Salvador & 17.0 & 15.9 & 14.9 & 13.1 & 12.8 & 9.9 & 7.3 & 11.3 & 4.2 & 6.0 & 7.6 & 1.8 \\
\hline Guatemala & 20.8 & 20.8 & 16.4 & 16.8 & 15.8 & 15.6 & 11.8 & 16.2 & 5.0 & 5.2 & 4.5 & 0.6 \\
\hline Haiti & 29.3 & 30.5 & 28.8 & 27.4 & 27.6 & 29.0 & 24.3 & 23.8 & 1.7 & 1.4 & 4.5 & 3.6 \\
\hline Honduras & 28.3 & 33.2 & 35.5 & 19.6 & 24.6 & 24.2 & 22.6 & 16.5 & 3.7 & 9.0 & 12.9 & 3.1 \\
\hline Mexico & 25.9 & 25.6 & 26.9 & 22.4 & 25.5 & 24.8 & 25.4 & 21.8 & 0.5 & 0.8 & 1.5 & 0.6 \\
\hline Nicaragua & 30.8 & 33.2 & 33.6 & 23.4 & 17.2 & 15.3 & 9.4 & 10.5 & 13.6 & 17.9 & 24.2 & 12.9 \\
\hline Panama & 19.5 & 24.1 & 27.4 & 24.5 & 16.8 & 17.0 & 15.9 & 24.5 & 2.6 & 7.1 & 11.5 & 0.0 \\
\hline Paraguay & 19.6 & 18.0 & 18.1 & 15.5 & 21.0 & 19.5 & 15.8 & 14.1 & -1.4 & -1.5 & 2.3 & 1.4 \\
\hline Peru & 20.0 & 22.9 & 27.2 & 22.5 & 23.2 & 24.2 & 23.6 & 22.7 & -3.1 & -1.3 & 3.7 & -0.2 \\
\hline Dominican Republic & 18.4 & 18.9 & 18.3 & 14.8 & 14.8 & 13.6 & 8.4 & 9.8 & 3.6 & 5.3 & 9.9 & 5.0 \\
\hline Uruguay & 19.4 & 19.4 & 22.7 & 17.9 & 17.4 & 18.4 & 17.9 & 18.8 & 2.0 & 0.9 & 4.8 & -0.8 \\
\hline Venezuela (Bolivarian Republic of) & 26.9 & 29.2 & 25.9 & 24.8 & 41.6 & 37.3 & 38.1 & 27.4 & -14.7 & -8.1 & -12.2 & -2.6 \\
\hline
\end{tabular}

Source: Economic Commission for Latin America and the Caribbean (ECLAC), on the basis of official figures.

a Based on values calculated in national currency and expressed in current dollars.

b Preliminary figures. 
Table A-9

LATIN AMERICA AND THE CARIBBEAN: BALANCE OF PAYMENTS

(Millions of dollars)

\begin{tabular}{|c|c|c|c|c|c|c|c|c|c|c|c|}
\hline \multicolumn{3}{|c|}{ Exports of goods f.o.b. } & \multicolumn{3}{|c|}{ Exports of services } & \multicolumn{3}{|c|}{ Imports of goods f.o.b. } & \multicolumn{3}{|c|}{ Imports of services } \\
\hline 2007 & 2008 & $2009^{c}$ & 2007 & 2008 & $2009^{c}$ & 2007 & 2008 & $2009^{c}$ & 2007 & 2008 & $2009^{c}$ \\
\hline
\end{tabular}

Latin America and the Caribbean

$\begin{array}{llllllllllllll}766 & 018 & 887630 & 691919 & 100495 & 115120 & 103907 & 703485853331 & 642145 & 123630 & 145383 & 134169\end{array}$

\begin{tabular}{|c|c|c|c|c|c|c|c|c|c|c|c|c|}
\hline Antigua and Barbuda & 76 & 78 & 72 & 517 & 564 & 523 & 649 & 671 & 589 & 283 & 271 & 248 \\
\hline Argentina & 55980 & 70021 & 55750 & 10347 & 12087 & 10954 & 42525 & 54557 & 37130 & 10806 & 13030 & 11711 \\
\hline Bahamas & 802 & 956 & 666 & 2599 & 2543 & 2272 & 2956 & 3199 & 2540 & 1580 & 1403 & 1197 \\
\hline Barbados & 524 & 488 & 379 & 1517 & 1601 & 1432 & 1607 & 1730 & 1295 & 606 & 705 & 635 \\
\hline Belize & 426 & 480 & 382 & 398 & 386 & 345 & 642 & 788 & 621 & 164 & 170 & 162 \\
\hline $\begin{array}{l}\text { Bolivia (Plurinational } \\
\text { State of) }\end{array}$ & 4458 & 6448 & 4848 & 499 & 500 & 515 & 3243 & 4641 & 4087 & 900 & 1039 & 1015 \\
\hline Brazil & 160649 & 197942 & 152995 & 23954 & 30451 & 27750 & 120617 & 173107 & 127647 & 37173 & 47140 & 47011 \\
\hline Chile & 67972 & 66464 & 53735 & 8962 & 10785 & 8507 & 44031 & 57617 & 39754 & 9950 & 11656 & 9581 \\
\hline Colombia & 30577 & 38531 & 34026 & 3636 & 4047 & 4191 & 31173 & 37556 & 31466 & 6243 & 7187 & 6871 \\
\hline Costa Rica & 9299 & 9554 & 8847 & 3552 & 4146 & 3812 & 12285 & 14569 & 10871 & 1818 & 1893 & 1654 \\
\hline Cuba & 3830 & $\ldots$ & $\ldots$ & 8192 & $\ldots$ & $\ldots$ & 10083 & $\ldots$ & $\ldots$ & 292 & $\ldots$ & 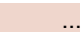 \\
\hline Dominica & 39 & 44 & 38 & 109 & 108 & 104 & 172 & 217 & 205 & 66 & 70 & 64 \\
\hline Ecuador & 14870 & 19147 & 14344 & 1200 & 1313 & 1214 & 13047 & 17776 & 14269 & 2572 & 2954 & 2604 \\
\hline El Salvador & 4039 & 4611 & 3861 & 1130 & 1041 & 835 & 8144 & 9004 & 6706 & 1420 & 1625 & 1260 \\
\hline Grenada & 41 & 41 & 39 & 147 & 153 & 140 & 328 & 339 & 253 & 111 & 113 & 93 \\
\hline Guatemala & 6983 & 7847 & 7330 & 1731 & 1873 & 1513 & 12470 & 13421 & 10632 & 2041 & 2149 & 1883 \\
\hline Guyana & 698 & 802 & 768 & 173 & 212 & 170 & 1063 & 1324 & 1169 & 272 & 325 & 272 \\
\hline Haiti & 522 & 490 & 551 & 257 & 343 & 382 & 1704 & 2108 & 2032 & 680 & 746 & 781 \\
\hline Honduras & 5784 & 6458 & 5090 & 781 & 877 & 938 & 8888 & 10509 & 7560 & 1069 & 1187 & 1081 \\
\hline Jamaica & 2363 & 2761 & 1386 & 2707 & 2777 & 2736 & 6204 & 7742 & 4510 & 2282 & 2421 & 1984 \\
\hline Mexico & 271875 & 291343 & 229707 & 17489 & 18040 & 14767 & 281949 & 308603 & 234385 & 23794 & 25119 & 22792 \\
\hline Nicaragua & 2336 & 2538 & 2387 & 373 & 399 & 470 & 4094 & 4749 & 3927 & 555 & 608 & 555 \\
\hline Panama & 9334 & 10323 & 10904 & 4958 & 5826 & 5438 & 12524 & 14869 & 12931 & 2122 & 2621 & 2166 \\
\hline Paraguay & 5652 & 7772 & 5784 & 962 & 1142 & 1233 & 6185 & 8946 & 6835 & 463 & 596 & 531 \\
\hline Peru & 27882 & 31529 & 26885 & 3152 & 3649 & 3653 & 19595 & 28439 & 21011 & 4343 & 5611 & 4765 \\
\hline Dominican Republic & 7160 & 6748 & 5463 & 4798 & 4922 & 4935 & 13597 & 15993 & 12283 & 1746 & 1960 & 1847 \\
\hline Saint Kitts and Nevis & 58 & 69 & 58 & 174 & 160 & 131 & 242 & 286 & 266 & 102 & 123 & 115 \\
\hline Saint Vincent and the & & & & & & & & & & & & \\
\hline Grenadines & 51 & 57 & 55 & 162 & 153 & 145 & 288 & 329 & 294 & 114 & 110 & 107 \\
\hline Saint Lucia & 101 & 166 & 183 & 356 & 364 & 347 & 542 & 605 & 475 & 188 & 216 & 186 \\
\hline Suriname & 1359 & 1708 & 1404 & 253 & 285 & 287 & 1045 & 1350 & 1296 & 318 & 407 & 285 \\
\hline Trinidad and Tobago & 13391 & 18686 & 9175 & $\ldots$ & $\ldots$ & $\ldots$ & 7670 & 9622 & 6973 & 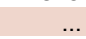 & $\ldots$ & \\
\hline Uruguay & 5100 & 7077 & 6389 & 1833 & 2215 & 2162 & 5645 & 8807 & 6664 & 1130 & 1411 & 1091 \\
\hline $\begin{array}{l}\text { Venezuela (Bolivarian } \\
\text { Republic of) }\end{array}$ & 69010 & 95138 & 57595 & 1767 & 2162 & 2005 & 46031 & 49482 & 38442 & 8719 & 10516 & 9622 \\
\hline
\end{tabular}


Table A-9 (continued)

\begin{tabular}{|c|c|c|c|c|c|c|c|c|c|c|c|c|}
\hline & \multicolumn{3}{|c|}{ Trade balance } & \multicolumn{3}{|c|}{ Income balance } & \multicolumn{3}{|c|}{ Current transfers balance } & \multicolumn{3}{|c|}{ Current account balance } \\
\hline & 2007 & 2008 & $2009^{c}$ & 2007 & 2008 & $2009^{c}$ & 2007 & 2008 & $2009^{c}$ & 2007 & 2008 & $2009^{c}$ \\
\hline $\begin{array}{l}\text { Latin America and } \\
\text { the Caribbean } d\end{array}$ & 39398 & 4034 & 19515 & -96896 & -106834 & -98124 & 67011 & 66932 & 60440 & 9506 & -35868 & -18171 \\
\hline Antigua and Barbuda & -340 & -301 & -242 & -64 & -69 & -34 & 24 & 15 & 15 & -379 & -354 & -262 \\
\hline Argentina & 12996 & 14521 & 17863 & -5941 & -7550 & -9272 & 328 & 119 & 2701 & 7383 & 7090 & 11292 \\
\hline Bahamas & -1135 & -1103 & -800 & -232 & -118 & -210 & 52 & 56 & 82 & -1315 & -1165 & -927 \\
\hline Barbados & -172 & -347 & -120 & -67 & -121 & -140 & 56 & 47 & 42 & -183 & -421 & -218 \\
\hline Belize & 17 & -91 & -55 & -159 & -153 & -117 & 97 & 112 & 80 & -52 & -132 & -93 \\
\hline $\begin{array}{l}\text { Bolivia (Plurinational } \\
\text { State of) }\end{array}$ & 815 & 1267 & 261 & -489 & -536 & -674 & 1266 & 1284 & 1213 & 1591 & 2015 & 801 \\
\hline Brazil & 26813 & 8146 & 6087 & -29291 & -40562 & -33684 & 4029 & 4224 & 3263 & 1551 & -28192 & -24334 \\
\hline Chile & 22954 & 7976 & 12907 & -18625 & -13423 & -10306 & 3129 & 2934 & 1616 & 7458 & -2513 & 4217 \\
\hline Colombia & -3203 & -2165 & -121 & -7847 & -10063 & -9644 & 5231 & 5514 & 4619 & -5819 & -6713 & -5146 \\
\hline Costa Rica & -1251 & -2761 & 134 & -865 & -434 & -1097 & 470 & 442 & 329 & -1646 & -2754 & -634 \\
\hline Cuba & 1647 & & $\ldots$ & -960 & & 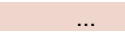 & -199 & 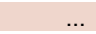 & & 488 & 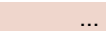 & \\
\hline Dominica & -90 & -135 & -127 & -16 & -20 & -14 & 21 & 19 & 18 & -85 & -136 & -123 \\
\hline Ecuador & 452 & -270 & -1315 & -2047 & -1590 & -1439 & 3170 & 2862 & 2443 & 1575 & 1002 & -311 \\
\hline El Salvador & -4395 & -4978 & -3270 & -576 & -536 & -664 & 3750 & 3832 & 3561 & -1221 & -1682 & -374 \\
\hline Grenada & -251 & -259 & -167 & -34 & -47 & -45 & 24 & 37 & 37 & -261 & -269 & -175 \\
\hline Guatemala & -5797 & -5851 & -3671 & -843 & -927 & -948 & 4854 & 5004 & 4402 & -1786 & -1773 & -217 \\
\hline Guyana & -465 & -635 & -502 & -11 & -15 & -17 & 287 & 329 & 300 & -189 & -321 & -220 \\
\hline Haiti & -1605 & -2021 & -1880 & 2 & 6 & 13 & 1517 & 1726 & 1635 & -86 & -289 & -232 \\
\hline Honduras & -3392 & -4362 & -2613 & -395 & -420 & -487 & 2671 & 2982 & 2652 & -1116 & -1800 & -449 \\
\hline Jamaica & -3417 & -4626 & -2372 & -662 & -680 & -586 & 2040 & 2083 & 2046 & -2038 & -3223 & -912 \\
\hline Mexico & -16379 & -24340 & -12703 & -18435 & -17010 & -14053 & 26415 & 25461 & 21517 & -8399 & -15889 & -5238 \\
\hline Nicaragua & -1941 & -2420 & -1625 & -135 & -161 & -190 & 1075 & 1068 & 1018 & -1001 & -1513 & -796 \\
\hline Panama & -354 & -1341 & 1246 & -1306 & -1574 & -1460 & 253 & 238 & 210 & -1407 & -2677 & -4 \\
\hline Paraguay & -34 & -628 & -350 & -155 & -162 & -345 & 373 & 405 & 500 & 184 & -385 & -196 \\
\hline Peru & 7095 & 1128 & 4761 & -8359 & -8774 & -7371 & 2626 & 2923 & 2856 & 1363 & -4723 & 247 \\
\hline Dominican Republic & -3385 & -6283 & -3733 & -2183 & -1759 & -1890 & 3401 & 3513 & 3296 & -2167 & -4529 & -2327 \\
\hline Saint Kitts and Nevis & -112 & -179 & -192 & -32 & -35 & -33 & 33 & 33 & 40 & -110 & -181 & -185 \\
\hline $\begin{array}{l}\text { Saint Vincent and } \\
\text { the Grenadines }\end{array}$ & -189 & -230 & -199 & -21 & -23 & -22 & 20 & 24 & 23 & -190 & -228 & -198 \\
\hline Saint Lucia & -272 & -291 & -131 & -68 & -72 & -69 & 14 & 16 & 13 & -327 & -347 & -187 \\
\hline Suriname & 250 & 236 & 110 & 8 & 21 & 5 & 77 & 87 & 94 & 335 & 344 & 210 \\
\hline Trinidad and Tobago & 6268 & 9674 & 2923 & -964 & -1202 & -1220 & 60 & 47 & 55 & 5364 & 8519 & 1759 \\
\hline Uruguay & 158 & -926 & 796 & -516 & -727 & -679 & 137 & 150 & 142 & -220 & -1503 & 259 \\
\hline $\begin{array}{l}\text { Venezuela (Bolivarian } \\
\text { Republic of) }\end{array}$ & 16027 & 37302 & 11536 & 2467 & 698 & -2652 & -431 & -608 & -323 & 18063 & 37392 & 8561 \\
\hline
\end{tabular}


Table A-9 (concluded)

\begin{tabular}{|c|c|c|c|c|c|c|c|c|c|c|c|c|}
\hline & \multicolumn{3}{|c|}{$\begin{array}{c}\text { Capital and } \\
\text { finantial balance }\end{array}$} & \multicolumn{3}{|c|}{ Overall balance } & \multicolumn{3}{|c|}{$\begin{array}{l}\text { Reserve assets } \\
\text { (variation) }{ }^{\mathrm{b}}\end{array}$} & \multicolumn{3}{|c|}{ Other financing } \\
\hline & 2007 & 2008 & $2009^{c}$ & 2007 & 2008 & $2009^{c}$ & 2007 & 2008 & $2009^{c}$ & 2007 & 2008 & 2009 \\
\hline $\begin{array}{l}\text { Latin America and } \\
\text { the Caribbean } d\end{array}$ & 114305 & 71390 & 63846 & 123812 & 35523 & 45675 & -125740 & -39160 & -53011 & 1929 & 3638 & 7333 \\
\hline Antigua and Barbuda & 380 & 348 & 233 & 1 & -6 & -30 & -1 & 6 & 30 & 0 & 0 & 0 \\
\hline Argentina & 4216 & -10389 & -14793 & 11600 & -3299 & -3501 & -13098 & -9 & -1346 & 1499 & 3309 & 4848 \\
\hline Bahamas & 1269 & 1274 & 1180 & -46 & 109 & 253 & 46 & -109 & -253 & 0 & 0 & 0 \\
\hline Barbados & 359 & 326 & 243 & 177 & -96 & 25 & -177 & 96 & -25 & 0 & 0 & 0 \\
\hline Belize & 75 & 190 & 141 & 23 & 58 & 47 & -23 & -58 & -47 & 0 & 0 & 0 \\
\hline Bolivia (Plurinational & & & & & & & & & & & & \\
\hline State of) & 346 & 359 & -475 & 1938 & 2374 & 326 & -1938 & -2374 & -326 & 0 & 0 & 0 \\
\hline Brazil & 85934 & 31161 & 70985 & 87484 & 2969 & 46651 & -87484 & -2969 & -46651 & 0 & 0 & 0 \\
\hline Chile & -10672 & 8957 & -2569 & -3214 & 6444 & 1648 & 3214 & -6444 & -1648 & 0 & 0 & 0 \\
\hline Colombia & 10532 & 9351 & 6493 & 4714 & 2638 & 1347 & -4714 & -2638 & -1347 & 0 & 0 & 0 \\
\hline Costa Rica & 2794 & 2406 & 895 & 1148 & -348 & 260 & -1148 & 348 & -260 & 0 & 0 & 0 \\
\hline Cuba & $\ldots$ & & & $\ldots$ & $\ldots$ & $\ldots$ & $\ldots$ & $\ldots$ & $\ldots$ & $\ldots$ & $\ldots$ & $\ldots$ \\
\hline Dominica & 84 & 133 & 131 & -1 & -3 & 8 & 1 & 3 & -8 & 0 & 0 & 0 \\
\hline Ecuador & -188 & -68 & -2337 & 1387 & 934 & -2647 & -1497 & -952 & 681 & 111 & 18 & 1966 \\
\hline El Salvador & 1502 & 2016 & 802 & 280 & 334 & 429 & -280 & -334 & -429 & 0 & 0 & 0 \\
\hline Grenada & 271 & 261 & 183 & 11 & -8 & 8 & -11 & 8 & -8 & 0 & 0 & 0 \\
\hline Guatemala & 2002 & 2106 & 690 & 216 & 333 & 473 & -216 & -333 & -473 & 0 & 0 & 0 \\
\hline Guyana & 188 & 327 & 454 & -1 & 6 & 234 & -37 & -43 & -271 & 39 & 38 & 37 \\
\hline Haiti & 284 & 387 & 388 & 198 & 98 & 156 & -208 & -171 & -246 & 10 & 73 & 90 \\
\hline Honduras & 930 & 1633 & 24 & -186 & -167 & -424 & 109 & 78 & 354 & 78 & 89 & 71 \\
\hline Jamaica & 1598 & 3118 & 869 & -440 & -105 & -44 & 440 & 105 & 44 & 0 & 0 & 0 \\
\hline Mexico & 18685 & 23327 & 10572 & 10286 & 7438 & 5334 & -10286 & -7438 & -5334 & 0 & 0 & 0 \\
\hline Nicaragua & 1093 & 1499 & 1004 & 92 & -14 & 208 & -173 & -30 & -262 & 80 & 45 & 54 \\
\hline Panama & 2029 & 3262 & 614 & 622 & 585 & 610 & -611 & -579 & -610 & -10 & -5 & 0 \\
\hline Paraguay & 539 & 763 & 1152 & 723 & 379 & 956 & -727 & -378 & -956 & 5 & 0 & 0 \\
\hline Peru & 8961 & 8179 & 1660 & 10324 & 3456 & 1907 & -10391 & -3512 & -1943 & 67 & 57 & 36 \\
\hline Dominican Republic & 2794 & 4203 & 2736 & 627 & -326 & 410 & -683 & 309 & -641 & 56 & 17 & 232 \\
\hline Saint Kitts and Nevis & 117 & 196 & 198 & 7 & 15 & 13 & -7 & -15 & -13 & 0 & 0 & 0 \\
\hline Saint Vincent and the & & & & & & & & & & & & \\
\hline Grenadines & 188 & 225 & 190 & -2 & -3 & -8 & 2 & 3 & 3 & 0 & 0 & 0 \\
\hline Saint Lucia & 345 & 336 & 197 & 19 & -11 & 10 & -19 & 11 & -10 & 0 & 0 & 0 \\
\hline Suriname & -160 & -292 & 16 & 175 & 52 & 226 & -175 & -52 & -226 & 0 & 0 & 0 \\
\hline Trinidad and Tobago & -3824 & -5813 & -2472 & 1541 & 2706 & -713 & -1541 & -2706 & 713 & 0 & 0 & 0 \\
\hline Uruguay & 1231 & 3736 & 1330 & 1010 & 2233 & 1589 & -1005 & -2232 & -1588 & -5 & 0 & 0 \\
\hline $\begin{array}{l}\text { Venezuela (Bolivarian } \\
\text { Republic of) }\end{array}$ & -23420 & -27936 & -19360 & -5357 & 9456 & -10799 & 5357 & -9456 & 10799 & 0 & 0 & 0 \\
\hline
\end{tabular}

Source: Economic Commission for Latin America and the Caribbean (ECLAC), on the basis of official figures from the International Monetary Fund (IMF) and national sources.

a Includes errors and omissions.

A minus sign (-) indicates an increase in reserve assets.

Preliminary figures.

d Does not include Cuba and Trinidad and Tobago. 
Table A-10

LATIN AMERICA AND THE CARIBBEAN: EXPORTS OF GOODS, f.o.b.

(Indices 2000=100)

\begin{tabular}{|c|c|c|c|c|c|c|c|c|c|}
\hline & \multicolumn{3}{|c|}{ Value } & \multicolumn{3}{|c|}{ Volume } & \multicolumn{3}{|c|}{ Unit value } \\
\hline & 2007 & 2008 & $2009^{a}$ & 2007 & 2008 & $2009^{a}$ & 2007 & 2008 & $2009^{a}$ \\
\hline Latin America and the Caribbean ${ }^{b}$ & 210.4 & 243.8 & 190.2 & 141.8 & 142.5 & 129.0 & 148.4 & 171.1 & 147.4 \\
\hline Argentina & 212.5 & 265.8 & 211.6 & 155.6 & 155.8 & 149.1 & 136.6 & 170.6 & 142.0 \\
\hline Bolivia (Plurinational State of) & 357.8 & 517.5 & 389.0 & 180.1 & 242.6 & 198.3 & 198.6 & 213.3 & 196.2 \\
\hline Brazil & 291.6 & 359.3 & 277.7 & 195.0 & 190.2 & 169.7 & 149.6 & 189.0 & 163.6 \\
\hline Chile & 353.8 & 346.0 & 279.7 & 156.0 & 153.8 & 146.3 & 226.9 & 224.9 & 191.2 \\
\hline Colombia & 222.2 & 280.0 & 247.3 & 143.3 & 149.2 & 164.7 & 155.1 & 187.6 & 150.1 \\
\hline Costa Rica & 160.0 & 164.4 & 152.2 & 167.3 & 168.5 & 166.0 & 95.6 & 97.5 & 91.7 \\
\hline Cuba & 228.6 & $\ldots$ & $\ldots$ & 98.1 & $\ldots$ & $\ldots$ & 232.9 & $\ldots$ & $\ldots$ \\
\hline Ecuador & 294.1 & 378.6 & 283.7 & 192.6 & 200.0 & 194.6 & 152.7 & 189.3 & 145.8 \\
\hline El Salvador & 136.3 & 155.6 & 130.3 & 121.1 & 133.0 & 116.0 & 112.5 & 117.0 & 112.3 \\
\hline Guatemala & 176.3 & 198.1 & 185.1 & 148.0 & 151.1 & 146.2 & 119.1 & 131.1 & 126.6 \\
\hline Haiti & 157.4 & 147.8 & 166.1 & 136.7 & 124.0 & 126.7 & 115.2 & 119.2 & 131.1 \\
\hline Honduras & 173.0 & 193.1 & 152.2 & 174.3 & 180.2 & 152.7 & 99.2 & 107.2 & 99.7 \\
\hline Mexico & 163.7 & 175.4 & 138.3 & 126.5 & 126.9 & 108.8 & 129.4 & 138.2 & 127.1 \\
\hline Nicaragua & 265.2 & 288.2 & 271.0 & 249.3 & 250.8 & 244.4 & 106.4 & 114.9 & 110.9 \\
\hline Panama & 159.9 & 176.8 & 186.8 & 145.2 & 153.0 & 164.9 & 110.1 & 115.6 & 113.3 \\
\hline Paraguay & 242.7 & 333.7 & 248.3 & 202.4 & 235.9 & 199.5 & 119.9 & 141.5 & 124.5 \\
\hline Peru & 400.9 & 453.3 & 386.6 & 179.5 & 193.1 & 188.2 & 223.4 & 234.7 & 205.4 \\
\hline Dominican Republic & 124.8 & 117.6 & 95.2 & 103.3 & 91.8 & 79.9 & 120.9 & 128.1 & 119.2 \\
\hline Uruguay & 213.9 & 296.9 & 268.0 & 172.9 & 181.8 & 196.8 & 123.7 & 163.3 & 136.2 \\
\hline Venezuela (Bolivarian Republic of) & 205.8 & 283.7 & 171.8 & 84.5 & 85.0 & 77.2 & 243.6 & 333.8 & 222.6 \\
\hline
\end{tabular}

Source: Economic Commission for Latin America and the Caribbean (ECLAC), on the basis of official figures from the International Monetary Fund (IMF) and national sources.

a Preliminary figures.

b Does not include Cuba.

Table A-11

LATIN AMERICA AND THE CARIBBEAN: IMPORTS OF GOODS, f.o.b.

(Indices 2000=100)

\begin{tabular}{|c|c|c|c|c|c|c|c|c|c|}
\hline & \multicolumn{3}{|c|}{ Value } & \multicolumn{3}{|c|}{ Volume } & \multicolumn{3}{|c|}{ Unit value } \\
\hline & 2007 & 2008 & $2009^{\text {a }}$ & 2007 & 2008 & 2009 a & 2007 & 2008 & $2009^{a}$ \\
\hline Latin America and the Caribbean ${ }^{b}$ & 192.3 & 233.4 & 175.8 & 152.8 & 165.7 & 136.8 & 125.9 & 140.9 & 128.5 \\
\hline Argentina & 178.0 & 228.4 & 155.4 & 153.2 & 178.3 & 139.1 & 116.2 & 128.1 & 111.7 \\
\hline Bolivia (Plurinational State of) & 201.4 & 288.2 & 253.8 & 144.1 & 194.5 & 180.3 & 139.8 & 148.2 & 140.8 \\
\hline Brazil & 216.2 & 310.3 & 228.8 & 154.1 & 181.3 & 150.7 & 140.3 & 171.2 & 151.8 \\
\hline Chile & 257.6 & 337.1 & 232.6 & 215.1 & 247.0 & 202.8 & 119.7 & 136.5 & 114.7 \\
\hline Colombia & 281.1 & 338.7 & 283.7 & 225.5 & 249.3 & 224.6 & 124.6 & 135.9 & 126.3 \\
\hline Costa Rica & 203.9 & 241.8 & 180.5 & 181.1 & 202.6 & 166.1 & 112.6 & 119.4 & 108.6 \\
\hline Cuba & 210.3 & $\ldots$ & $\ldots$ & 155.8 & $\ldots$ & $\ldots$ & 135.0 & $\ldots$ & $\ldots$ \\
\hline Ecuador & 356.7 & 486.0 & 390.1 & 264.0 & 318.3 & 293.7 & 135.1 & 152.7 & 132.8 \\
\hline El Salvador & 173.2 & 191.5 & 142.6 & 145.5 & 150.4 & 120.4 & 119.0 & 127.3 & 118.4 \\
\hline Guatemala & 224.3 & 241.4 & 191.2 & 165.5 & 157.6 & 140.3 & 135.5 & 153.1 & 136.3 \\
\hline Haiti & 156.8 & 194.0 & 187.0 & 117.7 & 101.1 & 114.7 & 133.2 & 191.9 & 163.1 \\
\hline Honduras & 222.9 & 263.5 & 189.6 & 183.3 & 188.5 & 155.8 & 121.6 & 139.8 & 121.7 \\
\hline Mexico & 161.6 & 176.9 & 134.4 & 131.2 & 135.5 & 108.3 & 123.2 & 130.5 & 124.0 \\
\hline Nicaragua & 227.3 & 263.6 & 218.0 & 168.0 & 172.4 & 162.0 & 135.3 & 152.9 & 134.5 \\
\hline Panama & 179.4 & 213.0 & 185.2 & 146.6 & 158.3 & 147.2 & 122.3 & 134.6 & 125.8 \\
\hline Paraguay & 215.8 & 312.1 & 238.5 & 180.1 & 236.8 & 201.1 & 119.8 & 131.8 & 118.6 \\
\hline Peru & 266.3 & 386.5 & 285.6 & 187.9 & 225.0 & 179.5 & 141.7 & 171.8 & 159.1 \\
\hline Dominican Republic & 143.5 & 168.7 & 129.6 & 116.4 & 123.3 & 110.1 & 123.3 & 136.9 & 117.7 \\
\hline Uruguay & 170.5 & 266.0 & 201.3 & 122.3 & 153.2 & 143.1 & 139.4 & 173.6 & 140.6 \\
\hline Venezuela (Bolivarian Republic of) & 272.9 & 293.4 & 227.9 & 226.4 & 219.3 & 186.0 & 120.5 & 133.8 & 122.6 \\
\hline
\end{tabular}

Source: Economic Commission for Latin America and the Caribbean (ECLAC), on the basis of official figures from the International Monetary Fund (IMF) and national sources.

a Preliminary figures.

b Does not include Cuba. 
Table A-12

LATIN AMERICA AND THE CARIBBEAN: TERMS OF TRADE FOR GOODS f.o.b. / f.o.b. (Indices 2000=100)

\begin{tabular}{|c|c|c|c|c|c|c|c|c|c|}
\hline & 2001 & 2002 & 2003 & 2004 & 2005 & 2006 & 2007 & 2008 & $2009^{a}$ \\
\hline Latin America and the Caribbean ${ }^{b}$ & 96.3 & 96.6 & 98.6 & 103.5 & 108.6 & 115.2 & 117.9 & 121.5 & 114.7 \\
\hline Argentina & 99.3 & 98.7 & 107.2 & 109.2 & 106.9 & 113.4 & 117.5 & 133.2 & 127.1 \\
\hline Bolivia (Plurinational State of) & 95.8 & 96.2 & 98.5 & 104.1 & 111.8 & 139.8 & 142.1 & 143.9 & 139.4 \\
\hline Brazil & 99.6 & 98.4 & 97.0 & 97.9 & 99.2 & 104.4 & 106.6 & 110.4 & 107.8 \\
\hline Chile & 93.3 & 97.2 & 102.8 & 124.9 & 139.8 & 183.2 & 189.5 & 164.8 & 166.7 \\
\hline Colombia & 94.2 & 92.5 & 95.2 & 102.3 & 111.0 & 115.2 & 124.4 & 138.1 & 118.8 \\
\hline Costa Rica & 98.4 & 96.9 & 95.5 & 91.9 & 88.3 & 85.8 & 84.9 & 81.7 & 84.4 \\
\hline Cuba & 114.0 & 105.1 & 121.0 & 133.3 & 129.8 & 164.0 & 172.6 & & \\
\hline Ecuador & 84.6 & 86.8 & 89.8 & 91.5 & 102.4 & 109.9 & 113.0 & 124.0 & 109.7 \\
\hline El Salvador & 102.5 & 101.6 & 97.7 & 96.8 & 96.8 & 95.5 & 94.6 & 91.9 & 94.9 \\
\hline Guatemala & 96.7 & 95.8 & 93.0 & 92.1 & 91.3 & 89.6 & 87.9 & 85.6 & 92.9 \\
\hline Haiti & 101.2 & 100.2 & 98.7 & 96.0 & 92.4 & 88.9 & 86.4 & 62.1 & 80.4 \\
\hline Honduras & 94.8 & 92.0 & 88.0 & 87.2 & 87.2 & 83.2 & 81.6 & 76.6 & 81.9 \\
\hline Mexico & 97.4 & 97.9 & 98.8 & 101.6 & 103.6 & 104.1 & 105.1 & 105.9 & 102.5 \\
\hline Nicaragua & 88.4 & 87.0 & 84.1 & 82.5 & 81.4 & 79.4 & 78.6 & 75.2 & 82.4 \\
\hline Panama & 102.7 & 101.6 & 97.2 & 95.3 & 93.5 & 90.8 & 90.0 & 85.9 & 90.0 \\
\hline Paraguay & 100.2 & 96.7 & 101.4 & 104.3 & 97.4 & 95.5 & 100.1 & 107.3 & 105.0 \\
\hline Peru & 95.6 & 98.4 & 102.2 & 111.3 & 119.4 & 152.1 & 157.6 & 136.7 & 129.1 \\
\hline Dominican Republic & 100.9 & 101.5 & 97.9 & 96.7 & 95.8 & 94.9 & 98.0 & 93.6 & 101.3 \\
\hline Uruguay & 104.0 & 102.6 & 103.5 & 99.9 & 90.7 & 88.6 & 88.7 & 94.1 & 96.9 \\
\hline Venezuela (Bolivarian Republic of) & 82.2 & 87.6 & 98.7 & 118.1 & 154.4 & 184.4 & 202.1 & 249.5 & 181.7 \\
\hline
\end{tabular}

Source: Economic Commission for Latin America and the Caribbean (ECLAC), on the basis of official figures from the International Monetary Fund (IMF) and national sources. a Preliminary figures.

Does not include Cuba.

Table A-13

LATIN AMERICA AND THE CARIBBEAN: NET RESOURCE TRANSFER (Millions of dollars)

\begin{tabular}{|c|c|c|c|c|c|c|c|c|c|}
\hline & 2001 & 2002 & 2003 & 2004 & 2005 & 2006 & 2007 & 2008 & $2009^{b}$ \\
\hline Latin America and the Caribbean ${ }^{c}$ & -1552 & -41419 & -39521 & -68933 & -80539 & -96694 & 14551 & -38821 & -30636 \\
\hline $\begin{array}{l}\text { Antigua and Barbuda } \\
\text { Argentina }\end{array}$ & $\begin{array}{r}48 \\
-16016\end{array}$ & $\begin{array}{r}49 \\
-20773\end{array}$ & $\begin{array}{r}85 \\
-12535\end{array}$ & $\begin{array}{r}56 \\
-7175\end{array}$ & $\begin{array}{r}136 \\
-3722\end{array}$ & $\begin{array}{r}260 \\
-10388\end{array}$ & $\begin{array}{r}316 \\
-226\end{array}$ & $\begin{array}{r}280 \\
-14630\end{array}$ & $\begin{array}{r}199 \\
-19218\end{array}$ \\
\hline Bahamas & 366 & 175 & 279 & 213 & 358 & 1077 & 1037 & 1156 & 971 \\
\hline Barbados & 241 & 42 & 131 & 58 & 263 & 89 & 293 & 204 & 102 \\
\hline Belize & 115 & 91 & 61 & 8 & 25 & -50 & -84 & 38 & 23 \\
\hline Bolivia (Plurinational State of) & 30 & -156 & -235 & -565 & -535 & -428 & -143 & -177 & -1149 \\
\hline Brazil & 6778 & -10252 & -14234 & -29955 & -35633 & -10553 & 56642 & -9401 & 37301 \\
\hline Chile & -2022 & -2068 & -4076 & -10102 & -10220 & -23558 & -29297 & -4466 & -12876 \\
\hline Colombia & -323 & -1439 & -2609 & -850 & -1846 & -2924 & 2686 & -712 & -3151 \\
\hline Costa Rica & -63 & 580 & 443 & 432 & 1166 & 2058 & 1929 & 1971 & -203 \\
\hline Cuba & 92 & -300 & -450 & 150 & -633 & -618 & -960 & & \\
\hline Dominica & 39 & 36 & 32 & 23 & 64 & 49 & 68 & 113 & 117 \\
\hline Ecuador & -816 & -100 & -953 & -1084 & -1520 & -3584 & -2124 & -1640 & -1809 \\
\hline El Salvador & -293 & -42 & 595 & 132 & -28 & 324 & 925 & 1480 & 138 \\
\hline Grenada & 67 & 109 & 83 & 30 & 131 & 170 & 237 & 214 & 138 \\
\hline Guatemala & 1618 & 993 & 1251 & 1359 & 995 & 1096 & 1160 & 1179 & -258 \\
\hline Guyana & -3 & 20 & -6 & -10 & 143 & 242 & 215 & 350 & 474 \\
\hline Haiti & 129 & 26 & 5 & 94 & -20 & 201 & 296 & 465 & 491 \\
\hline Honduras & 322 & 86 & 94 & 743 & 177 & 149 & 612 & 1303 & -392 \\
\hline Jamaica & 1168 & 208 & -246 & 612 & 561 & 797 & 937 & 2438 & 283 \\
\hline Mexico & 11161 & 8502 & 4315 & -1286 & -2674 & -15083 & 250 & 6317 & -3481 \\
\hline Nicaragua & 455 & 607 & 520 & 616 & 590 & 768 & 1039 & 1383 & 868 \\
\hline Panama & 202 & -39 & -539 & -414 & 418 & -648 & 712 & 1683 & -846 \\
\hline Paraguay & 237 & -134 & 168 & -98 & 72 & 168 & 388 & 601 & 806 \\
\hline Peru & 377 & 505 & -679 & -1262 & -4753 & -7224 & 669 & -539 & -5674 \\
\hline Dominican Republic & 168 & -881 & -2787 & -2324 & -321 & -221 & 666 & 2461 & 1078 \\
\hline Saint Kitts and Nevis & 84 & 95 & 71 & 43 & 23 & 74 & 85 & 161 & 165 \\
\hline Saint Vincent and the Grenadines & 30 & 18 & 55 & 99 & 70 & 108 & 167 & 202 & 168 \\
\hline Saint Lucia & 73 & 75 & 115 & 45 & 62 & 261 & 277 & 264 & 128 \\
\hline Suriname & 54 & 70 & 118 & 112 & 83 & -179 & -152 & -271 & 22 \\
\hline Trinidad and Tobago & -453 & -441 & -1344 & -1309 & -2461 & -7087 & -4787 & -7016 & -3691 \\
\hline Uruguay & 707 & -2601 & 979 & -137 & 84 & -52 & 710 & 3008 & 650 \\
\hline Venezuela (Bolivarian Republic of) & -6030 & -14783 & -8679 & -17037 & -22225 & -22603 & -20953 & -27238 & -22012 \\
\hline
\end{tabular}

Source: Economic Commission for Latin America and the Caribbean (ECLAC), on the basis of official figures from the International Monetary Fund (IMF) and national sources.

The net resource transfer is calculated as total net capital income minus the income balance (net payments of profits and interest). Total net capital income is the balance on the capital and financial accounts plus errors and omissions, plus loans and the use of IMF credit plus exceptional financing. Negative figures indicate resources transferrec outside the country.

b Preliminary figures.

Does not include Cuba. 
Table A-14

LATIN AMERICA AND THE CARIBBEAN: NET FOREIGN DIRECT INVESTMENT ${ }^{a}$ (Millions of dollars)

\begin{tabular}{|c|c|c|c|c|c|c|c|c|c|}
\hline & 2001 & 2002 & 2003 & 2004 & 2005 & 2006 & 2007 & 2008 & $2009^{b}$ \\
\hline Latin America and the Caribbean & 66122 & 50504 & 37806 & 49745 & 54703 & 31192 & 90214 & 94731 & 64621 \\
\hline Antigua and Barbuda & 98 & 66 & 166 & 80 & 214 & 374 & 356 & 173 & 130 \\
\hline Argentina & 2005 & 2776 & 878 & 3449 & 3954 & 3099 & 4969 & 8335 & 4216 \\
\hline Bahamas & 192 & 209 & 247 & 443 & 563 & 706 & 746 & 839 & 654 \\
\hline Barbados & 17 & 17 & 58 & -16 & 119 & 200 & 256 & 223 & \\
\hline Belize & 61 & 25 & -11 & 111 & 126 & 108 & 142 & 188 & 95 \\
\hline Bolivia (Plurinational State of) & 703 & 674 & 195 & 83 & -291 & 284 & 362 & 508 & 426 \\
\hline Brazil & 24715 & 14108 & 9894 & 8339 & 12550 & -9380 & 27518 & 24601 & 36033 \\
\hline Chile & 2590 & 2207 & 2701 & 5610 & 4801 & 4556 & 9961 & 7194 & 4719 \\
\hline Colombia & 2526 & 1277 & 783 & 2873 & 5590 & 5558 & 8136 & 8346 & 4177 \\
\hline Costa Rica & 451 & 625 & 548 & 733 & 904 & 1371 & 1634 & 2015 & 1316 \\
\hline Dominica & 17 & 20 & 31 & 26 & 33 & 27 & 53 & 57 & 52 \\
\hline Ecuador & 539 & 783 & 872 & 837 & 493 & 271 & 194 & 996 & 312 \\
\hline El Salvador & 289 & 496 & 123 & 366 & 398 & 268 & 1408 & 719 & 562 \\
\hline Grenada & 59 & 54 & 89 & 65 & 70 & 85 & 174 & 142 & 91 \\
\hline Guatemala & 488 & 183 & 218 & 255 & 470 & 552 & 720 & 737 & 543 \\
\hline Guyana & 56 & 44 & 26 & 30 & 77 & 102 & 110 & 178 & 164 \\
\hline Haiti & 4 & 6 & 14 & 6 & 26 & 161 & 75 & 30 & 38 \\
\hline Honduras & 301 & 269 & 391 & 553 & 599 & 669 & 926 & 901 & 500 \\
\hline Jamaica & 525 & 407 & 604 & 542 & 582 & 797 & 751 & 1361 & 670 \\
\hline Mexico & 23045 & 22158 & 15183 & 19249 & 15448 & 13558 & 19054 & 22013 & 3819 \\
\hline Nicaragua & 150 & 204 & 201 & 250 & 241 & 287 & 382 & 626 & 434 \\
\hline Panama & 467 & 99 & 818 & 1019 & 918 & 2557 & 1777 & 2402 & 1773 \\
\hline Paraguay & 78 & 12 & 22 & 32 & 47 & 167 & 199 & 171 & 281 \\
\hline Peru & 1070 & 2156 & 1275 & 1599 & 2579 & 3467 & 5425 & 6188 & 4364 \\
\hline Dominican Republic & 1079 & 917 & 613 & 909 & 1123 & 1085 & 1563 & 2971 & 2158 \\
\hline Saint Kitts and Nevis & 88 & 80 & 76 & 46 & 93 & 110 & 158 & 178 & 134 \\
\hline Saint Vincent and the Grenadines & 21 & 34 & 55 & 66 & 40 & 109 & 110 & 159 & 110 \\
\hline Saint Lucia & 59 & 52 & 106 & 77 & 78 & 234 & 253 & 161 & 157 \\
\hline Suriname & -27 & -74 & -76 & -37 & 28 & -163 & -247 & -234 & \\
\hline Trinidad and Tobago & 685 & 684 & 583 & 973 & 599 & 513 & 830 & 1638 & 509 \\
\hline Uruguay & 291 & 180 & 401 & 315 & 811 & 1495 & 1240 & 1839 & 1126 \\
\hline Venezuela (Bolivarian Republic of) & 3479 & -244 & 722 & 864 & 1422 & -2032 & 978 & -924 & -4939 \\
\hline
\end{tabular}

Source: Economic Commission for Latin America and the Caribbean (ECLAC), on the basis of official figures from the International Monetary Fund (IMF) and national sources.

a Corresponds to direct investment in the reporting economy after deduction of outward direct investment by residents of that country. Includes reinvestment of profits.

b Preliminary figures.

Table A-15

LATIN AMERICA AND THE CARIBBEAN: INTERNATIONAL BOND ISSUES ${ }^{a}$

(Millions of dollars)

\begin{tabular}{|c|c|c|c|c|c|c|c|c|c|c|c|}
\hline \multirow{3}{*}{ Latin America and the Caribbean } & \multirow{3}{*}{$\begin{array}{r}2001 \\
38503\end{array}$} & \multirow{3}{*}{$\begin{array}{r}2002 \\
20208\end{array}$} & \multirow{3}{*}{2003} & \multirow{3}{*}{$\begin{array}{r}2004 \\
36383\end{array}$} & \multirow{3}{*}{$2005^{b}$} & \multirow{3}{*}{$2006^{c}$} & \multirow{3}{*}{$2007^{d}$} & \multirow{3}{*}{$2008^{e}$} & \multirow{3}{*}{$\begin{array}{r}2009^{f} \\
61950\end{array}$} & \multicolumn{2}{|c|}{2010} \\
\hline & & & & & & & & & & \multicolumn{2}{|c|}{19} \\
\hline & & & & & & & & & & 21792 & 17370 \\
\hline $\begin{array}{l}\text { Argentina } \\
\text { Bahamas }\end{array}$ & 2711 & - & 100 & 200 & 540 & 1896 & 3256 & $\begin{array}{r}65 \\
100\end{array}$ & $\begin{array}{l}500 \\
300\end{array}$ & $\begin{array}{r}475 \\
-\end{array}$ & 500 \\
\hline Barbados & 150 & & & & 325 & 215 & & & 450 & 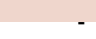 & 190 \\
\hline $\begin{array}{l}\text { Belize } \\
\text { Bolivia (Plurinational State of) }\end{array}$ & & 125 & 100 & 108 & & & & & & & \\
\hline Brazil & 13010 & 6857 & 19364 & 11603 & 15334 & 19079 & 10608 & 6400 & 25745 & 9776 & 6562 \\
\hline Chile & 1515 & 1694 & 3200 & 2350 & 1000 & 1062 & 250 & - & 2773 & 500 & 750 \\
\hline Colombia & 4329 & 695 & 1545 & 1545 & 2435 & 3177 & 3065 & 1000 & 5450 & - & 792 \\
\hline Costa Rica & 250 & 250 & 490 & 310 & - & - & - & - & - & - & - \\
\hline Cuba & - & - & - & - & - & 400 & 200 & - & - & - & \\
\hline Ecuador & - & - & - & - & 650 & - & - & - & - & - & - \\
\hline El Salvador & 354 & 1252 & 349 & 286 & 375 & 925 & - & - & 800 & - & - \\
\hline Grenada & - & 100 & - & - & - & - & - & - & - & - & - \\
\hline Guatemala & 325 & & 300 & 380 & - & - & - & 30 & - & - & \\
\hline Jamaica & 812 & 300 & & 814 & 1050 & 930 & 1900 & 350 & 750 & 775 & \\
\hline Mexico & 11016 & 6505 & 7979 & 13312 & 11703 & 9200 & 10296 & 5835 & 15359 & 9916 & 7826 \\
\hline Panama & 1100 & 1030 & 275 & 770 & 1530 & 2076 & 670 & 686 & 1323 & - & \\
\hline Peru & & 1000 & 1250 & 1305 & 2675 & 733 & 1827 & & 2150 & 350 & \\
\hline Dominican Republic & 500 & & 600 & & 160 & 675 & 605 & & & & 750 \\
\hline Trinidad and Tobago & & & & & 100 & 500 & & & 850 & - & \\
\hline Uruguay & 856 & 400 & & 350 & 1062 & 3679 & 999 & & 500 & - & \\
\hline Venezuela (Bolivarian Republic of) & 1575 & & 2354 & 3050 & 6115 & 100 & 7500 & 4000 & 5000 & - & \\
\hline
\end{tabular}

Source: Economic Commission for Latin America and the Caribbean (ECLAC), on the basis of figures from the International Monetary Fund (IMF), Merrill-Lynch and J.P. Morgan and Latin Finance.

a Includes sovereign, bank and corporate bonds.

Does not include US\$ 584 million issued by the Andean Development Corporation (ADC) and US\$200 million issued by the Central American Bank for Economic Integration (CABEI).

Does not include US $\$ 250$ million issued by the Andean Development Corporation (ADC), US\$ 250 million issued by the Latin American Reserve Fund (FLAR) and US\$ 567 million issued by the Central American Bank for Economic Integration (CABEI).

d Does not include US\$ 539 million issued by the Andean Development Corporation (ADC).

e Does not include US $\$ 447$ million issued by the Andean Development Corporation (ADC).

Does not include US $\$ 1$ billiion issued by the Andean Development Corporation (ADC), US $\$ 500$ million issued by the Central American Bank for Economic Integration (CABEI) and US $\$ 1,300$ million issued by the NII Holdings. 
Table A-16

LATIN AMERICA AND THE CARIBBEAN: TOTAL GROSS EXTERNAL DEBT ${ }^{\text {a }}$

(Millions of dollars)

\begin{tabular}{|c|c|c|c|c|c|c|c|c|c|}
\hline & 2001 & 2002 & 2003 & 2004 & 2005 & 2006 & 2007 & 2008 & $2009^{b}$ \\
\hline $\begin{array}{l}\text { Latin America and } \\
\text { the Caribbean }{ }^{c}\end{array}$ & 739695 & 728604 & 757138 & 758441 & 668676 & 657438 & 726451 & 744181 & 808180 \\
\hline Antigua and Barbuda & 388 & 434 & 497 & 532 & 317 & 321 & 501 & 524 & 496 \\
\hline Argentina & 166272 & 156748 & 164645 & 171205 & 113799 & 108864 & 124560 & 124923 & 117808 \\
\hline Bahamas $^{d}$ & 328 & 310 & 364 & 345 & 338 & 334 & 337 & 443 & 767 \\
\hline Barbados & 2267 & 2321 & 2475 & 2435 & 2695 & 2991 & 3130 & 3050 & 3294 \\
\hline Belize $^{d}$ & 495 & 652 & 822 & 913 & 970 & 985 & 973 & 958 & 1016 \\
\hline $\begin{array}{l}\text { Bolivia (Plurinational } \\
\text { State of) }\end{array}$ & 6861 & 6970 & 7734 & 7562 & 7666 & 6278 & 5403 & 5930 & 6033 \\
\hline Brazil & 209935 & 210711 & 214929 & 201373 & 169451 & 172589 & 193219 & 198340 & 198192 \\
\hline Chile & 38527 & 40504 & 43067 & 43515 & 46211 & 49497 & 55733 & 64318 & 74041 \\
\hline Colombia & 39163 & 37382 & 38065 & 39497 & 38507 & 40103 & 44553 & 46369 & 53746 \\
\hline Costa Rica & 5265 & 5310 & 5575 & 5710 & 6485 & 6994 & 8341 & 8857 & 8036 \\
\hline Cuba de & 10893 & 10900 & 11300 & 5806 & 5898 & 7794 & 8908 & & \\
\hline Dominica $^{d}$ & 178 & 205 & 223 & 209 & 221 & 225 & 221 & 217 & 219 \\
\hline Ecuador & 14376 & 16236 & 16756 & 17211 & 17237 & 17099 & 17445 & 16838 & 13359 \\
\hline El Salvador ${ }^{f}$ & 3148 & 3987 & 7917 & 8211 & 8761 & 9586 & 9075 & 9711 & 9710 \\
\hline Grenada & 154 & 262 & 279 & 331 & 401 & 481 & 502 & 513 & 542 \\
\hline Guatemala $^{d}$ & 2925 & 3119 & 3467 & 3844 & 3723 & 3958 & 4226 & 4382 & 4928 \\
\hline Guyana $^{d}$ & 1197 & 1247 & 1085 & 1071 & 1215 & 1043 & 718 & 834 & 933 \\
\hline Haiti $^{d}$ & 1189 & 1229 & 1316 & 1376 & 1335 & 1484 & 1628 & 1917 & 1272 \\
\hline Honduras & 4757 & 5025 & 5343 & 6023 & 5135 & 3935 & 3190 & 3464 & 3338 \\
\hline Jamaica $^{d}$ & 4146 & 4348 & 4192 & 5120 & 5376 & 5796 & 6123 & 6344 & 6594 \\
\hline Mexico & 144526 & 134980 & 132524 & 130925 & 128248 & 116792 & 124433 & 125233 & 162753 \\
\hline Nicaragua ${ }^{d}$ & 6374 & 6363 & 6596 & 5391 & 5348 & 4527 & 3385 & 3512 & 3661 \\
\hline Panama $^{d}$ & 6263 & 6349 & 6504 & 7219 & 7580 & 7788 & 8276 & 8477 & 10150 \\
\hline Paraguay & 2654 & 2900 & 2951 & 2901 & 2700 & 2739 & 2868 & 3191 & 3497 \\
\hline Peru & 27195 & 27872 & 29587 & 31244 & 28657 & 28897 & 32894 & 34838 & 35629 \\
\hline Dominican Republic ${ }^{d}$ & 4176 & 4536 & 5987 & 6380 & 5847 & 6296 & 6556 & 7226 & 8200 \\
\hline Saint Kitts and Nevis & 214 & 265 & 317 & 317 & 311 & 306 & 299 & 308 & 303 \\
\hline $\begin{array}{l}\text { Saint Vincent and } \\
\text { the Grenadines }\end{array}$ & 168 & 168 & 195 & 219 & 231 & 220 & 219 & 232 & 255 \\
\hline Saint Lucia ${ }^{d}$ & 204 & 246 & 324 & 344 & 350 & 365 & 375 & 364 & 375 \\
\hline Suriname $^{\mathrm{d}}$ & 350 & 371 & 382 & 384 & 390 & 391 & 299 & 316 & 238 \\
\hline Trinidad and Tobago ${ }^{d}$ & 1666 & 1549 & 1553 & 1364 & 1329 & 1261 & 1392 & 1445 & 1281 \\
\hline Uruguay & 8937 & 10548 & 11013 & 11593 & 11418 & 10560 & 12218 & 12021 & 13935 \\
\hline $\begin{array}{l}\text { Venezuela (Bolivarian } \\
\text { Republic of) }\end{array}$ & 35398 & 35460 & 40456 & 43679 & 46427 & 44735 & 53361 & 49087 & 63580 \\
\hline
\end{tabular}

Source: Economic Commission for Latin America and the Caribbean (ECLAC), on the basis of official figures from the International Monetary Fund (IMF) and national sources. Includes debt owed to the International Monetary Fund.

Preliminary figures.

Does not include Cuba.

Refers to external public debt.

From 2004 on refers only to active external debt; excludes other external debt, $60.2 \%$ of which is official debt owed to the Paris Club.

Up to 2002 corresponds to public external debt. 
Table A-17

LATIN AMERICA AND THE CARIBBEAN: GROSS INTERNATIONAL RESERVES

(Millions of dollars)

\begin{tabular}{llllllllllllllllll}
\hline 2001 & 2002 & 2003 & 2004 & 2005 & 2006 & 2007 & 2008 & 2009 & 2010
\end{tabular}

\begin{tabular}{|c|c|c|c|c|c|c|c|c|c|c|c|}
\hline Latin America and the Caribbean & 163177 & 164784 & 197615 & 225668 & 262168 & 319045 & 459152 & 512240 & 566961 & 560358 & 563270 \\
\hline Antigua and Barbuda ${ }^{b}$ & 80 & 88 & 114 & 120 & 127 & 143 & 144 & 138 & 108 & 128 & \\
\hline Argentina & 15318 & 10420 & 13820 & 19299 & 27262 & 31167 & 45711 & 46198 & 47967 & 47460 & $49000^{c}$ \\
\hline Bahamas & 312 & 373 & 484 & 668 & 579 & 500 & 454 & 563 & 816 & 819 & \\
\hline Barbados & 571 & 518 & 555 & 389 & 418 & 444 & 622 & 523 & 563 & 574 & $540^{c}$ \\
\hline Belize & & & & & & 95 & 99 & 156 & 210 & 203 & $208^{c}$ \\
\hline Bolivia (Plurinational State of) & 1129 & 897 & 1096 & 1272 & 1798 & 3193 & 5319 & 7722 & 8580 & 8449 & 8537 \\
\hline Brazil & 35866 & 37823 & 49296 & 52935 & 53799 & 85839 & 180334 & 193783 & 238520 & 243762 & 253114 \\
\hline Chile & 14400 & 15351 & 15851 & 16016 & 16963 & 19429 & 16910 & 23162 & 25371 & 25631 & 25175 \\
\hline Colombia & 9956 & 10540 & 10608 & 13220 & 14634 & 15109 & 20607 & 23672 & 24992 & 25140 & 26026 \\
\hline Costa Rica & 1384 & 1502 & 1839 & 1922 & 2313 & 3115 & 4114 & 3799 & 4066 & 4155 & 4057 \\
\hline Dominica $^{b}$ & 31 & 45 & 48 & 42 & 49 & 63 & 60 & 55 & 64 & & \\
\hline Ecuador $^{d}$ & $\ldots$ & $\ldots$ & $\ldots$ & $\ldots$ & 2147 & 2023 & 3521 & 4473 & 3792 & 4007 & 4104 \\
\hline El Salvador & 1712 & 1591 & 1910 & 1893 & 1833 & 1908 & 2198 & 2545 & 2987 & 2608 & 2684 \\
\hline Grenada ${ }^{b}$ & 64 & 88 & 83 & 122 & 94 & 100 & 110 & 104 & 112 & $\ldots$ & . \\
\hline Guatemala & 2359 & 2381 & 2932 & 3529 & 3783 & 4061 & 4310 & 4659 & 5213 & 5547 & \\
\hline Guyana & 285 & 280 & 272 & 225 & 251 & 277 & 313 & 356 & 628 & 608 & $652^{c}$ \\
\hline Haiti & 191 & 139 & 112 & 166 & 187 & 305 & 494 & 587 & 733 & 920 & \\
\hline Honduras & 1578 & 1687 & 1609 & 2159 & 2526 & 2824 & 2733 & 2690 & 2174 & 2250 & $2203^{c}$ \\
\hline Jamaica & 1903 & 1643 & 1196 & 1882 & 2169 & 2399 & 1906 & 1795 & 1752 & 2414 & 2527 \\
\hline Mexico & 44814 & 50674 & 59028 & 64198 & 74110 & 76330 & 87211 & 95302 & 99893 & 101606 & $103861^{c}$ \\
\hline Nicaragua & 383 & 454 & 504 & 670 & 730 & 924 & 1103 & 1141 & 1573 & 1485 & 1553 \\
\hline Panama $^{f}$ & 1092 & 1183 & 1011 & 631 & 1211 & 1335 & 1935 & 2424 & 3028 & $2803^{f}$ & \\
\hline Paraguay & 723 & 641 & 983 & 1168 & 1293 & 1703 & 2462 & 2864 & 3861 & 3855 & $3885^{c}$ \\
\hline Peru & 8838 & 9690 & 10206 & 12649 & 14120 & 17329 & 27720 & 31233 & 33175 & 35305 & 35382 \\
\hline Dominican Republic & 1341 & 829 & 279 & 825 & 1929 & 2251 & 2946 & 2662 & 3307 & 2738 & $2799^{e}$ \\
\hline Saint Kitts and Nevis ${ }^{b}$ & 57 & 66 & 65 & 78 & 71 & 89 & 96 & 110 & 123 & $\ldots$ & $\ldots$ \\
\hline Saint Vincent and the Grenadines ${ }^{b}$ & 61 & 52 & 50 & 74 & 69 & 78 & 86 & 83 & 75 & ... & $\ldots$ \\
\hline Saint Lucia ${ }^{b}$ & 87 & 92 & 105 & 130 & 114 & 132 & 151 & 140 & 151 & $\cdots$ & $\cdots$ \\
\hline Suriname ${ }^{f}$ & 119 & 106 & 106 & 129 & 126 & 215 & 401 & 433 & 659 & 642 & $652^{\mathrm{e}}$ \\
\hline Trinidad and Tobago & $\ldots$ & $\ldots$ & $\ldots$ & 2539 & 4015 & 5134 & 6674 & 9380 & 8652 & & \\
\hline Uruguay & $\begin{array}{l}\cdots \\
\cdots\end{array}$ & 772 & 2087 & 2512 & 3078 & 3091 & 4121 & 6360 & 7987 & 8061 & 7509 \\
\hline Venezuela (Bolivarian Republic of) & 18523 & 14860 & 21366 & 24208 & 30368 & 37440 & 34286 & 43127 & 35830 & 29186 & 28801 \\
\hline
\end{tabular}

Source: Economic Commission for Latin America and the Caribbean (ECLAC), on the basis of official figures from the International Monetary Fund (IMF) and national sources.

Balance as of June.

Net international reserves.

Balance as of May.

Freely available International reserves.

Balance as of April.

Does not include gold.

g Balance as of February. 
Table A-18

LATIN AMERICA AND THE CARIBBEAN: STOCK EXCHANGE INDICES

(National indices to end of period, 31 December 2000=100)

\begin{tabular}{|c|c|c|c|c|c|c|c|c|c|c|c|}
\hline & \multirow{2}{*}{2001} & \multirow{2}{*}{2002} & \multirow{2}{*}{2003} & \multirow{2}{*}{2004} & \multirow{2}{*}{2005} & \multirow{2}{*}{2006} & \multirow{2}{*}{2007} & \multirow{2}{*}{2008} & \multirow{2}{*}{2009} & \multicolumn{2}{|c|}{2010} \\
\hline & & & & & & & & & & I & II \\
\hline Argentina & 71 & 126 & 257 & 330 & 370 & 502 & 516 & 259 & 557 & 570 & 524 \\
\hline Brazil & 89 & 74 & 146 & 172 & 219 & 291 & 419 & 246 & 449 & 461 & 421 \\
\hline Chile & 109 & 92 & 137 & 166 & 181 & 248 & 281 & 219 & 330 & 347 & 380 \\
\hline Colombia & 134 & 206 & 291 & 542 & 1187 & 1393 & 1335 & 944 & 1448 & 1513 & 1561 \\
\hline Costa Rica & 113 & 117 & 104 & 88 & 96 & 169 & 193 & 177 & 139 & 137 & 135 \\
\hline Ecuador & 130 & 195 & 178 & 216 & 272 & 353 & 329 & 349 & 292 & 297 & 299 \\
\hline Jamaica & 117 & 157 & 234 & 390 & 362 & 348 & 374 & 277 & 288 & 298 & 301 \\
\hline Mexico & 113 & 108 & 156 & 229 & 315 & 468 & 523 & 396 & 568 & 589 & 576 \\
\hline Peru & 97 & 115 & 202 & 307 & 397 & 1066 & 1450 & 583 & 1172 & 1252 & 1172 \\
\hline Trinidad and Tobago & 98 & 124 & 157 & 243 & 242 & 220 & 222 & 191 & 173 & 185 & 187 \\
\hline Venezuela (Bolivarian Republic of) & 96 & 117 & 325 & 439 & 299 & 765 & 555 & 514 & 807 & 855 & 954 \\
\hline
\end{tabular}

Source: Economic Commission for Latin America and the Caribbean (ECLAC), on the basis of information from Bloomberg.

Table A-19

LATIN AMERICA AND THE CARIBBEAN: OVERALL REAL EFFECTIVE EXCHANGE RATES a

(Indices 2000=100, deflacted by CPI)

\begin{tabular}{|c|c|c|c|c|c|c|c|c|c|c|}
\hline & 2001 & 2002 & 2003 & 2004 & 2005 & 2006 & 2007 & 2008 & $2009^{b}$ & $2010^{b c}$ \\
\hline Latin America and the Caribbean ${ }^{d}$ & 99.2 & 111.1 & 120.6 & 119.6 & 111.9 & 108.8 & 105.3 & 98.8 & 98.0 & 95.9 \\
\hline Argentina & 96.0 & 228.3 & 208.3 & 214.0 & 213.7 & 218.0 & 213.8 & 201.6 & 210.0 & 206.6 \\
\hline Barbados & 98.6 & 100.4 & 104.9 & 107.8 & 106.0 & 104.1 & 105.0 & 104.7 & 100.0 & 100.7 \\
\hline Bolivia (Plurinational State of) & 101.2 & 95.4 & 104.0 & 109.5 & 116.8 & 119.5 & 118.6 & 110.4 & 100.6 & 105.9 \\
\hline Brazil & 120.1 & 132.6 & 131.1 & 123.8 & 100.5 & 88.9 & 82.7 & 80.1 & 81.4 & 71.9 \\
\hline Chile & 111.8 & 109.4 & 114.5 & 108.5 & 103.1 & 100.9 & 102.8 & 102.4 & 106.1 & 101.9 \\
\hline Colombia & 104.1 & 105.8 & 119.5 & 107.0 & 94.7 & 96.1 & 85.7 & 82.2 & 86.8 & 76.2 \\
\hline Costa Rica & 97.9 & 98.9 & 104.8 & 106.5 & 107.6 & 106.5 & 103.9 & 100.1 & 100.0 & 91.1 \\
\hline $\mathrm{Cuba}^{\mathrm{e}}$ & 90.6 & 94.2 & 99.8 & 106.2 & 105.1 & 112.2 & 115.1 & 126.1 & 126.0 & \\
\hline Dominica & 99.7 & 102.1 & 104.8 & 108.4 & 111.1 & 113.3 & 116.8 & 118.0 & 117.2 & 116.7 \\
\hline Ecuador & 70.8 & 61.9 & 60.3 & 61.7 & 64.7 & 65.4 & 68.1 & 68.4 & 65.0 & 63.0 \\
\hline El Salvador & 99.8 & 99.6 & 100.2 & 98.9 & 100.8 & 101.4 & 102.7 & 104.4 & 101.8 & 103.2 \\
\hline Guatemala & 96.1 & 88.7 & 88.6 & 85.8 & 79.3 & 76.9 & 76.3 & 72.5 & 75.1 & 75.1 \\
\hline Honduras & 97.2 & 97.0 & 98.5 & 101.0 & 100.6 & 98.1 & 97.9 & 95.2 & 88.3 & 88.1 \\
\hline Jamaica & 101.8 & 101.9 & 116.7 & 113.5 & 104.4 & 105.6 & 109.1 & 102.3 & 113.8 & 104.6 \\
\hline Mexico & 94.3 & 94.1 & 104.5 & 108.3 & 104.5 & 104.6 & 105.8 & 108.8 & 124.1 & 114.4 \\
\hline Nicaragua & 101.1 & 103.3 & 106.9 & 107.7 & 110.2 & 108.2 & 110.9 & 106.8 & 108.9 & 108.0 \\
\hline Panama & 103.1 & 101.3 & 103.3 & 108.4 & 110.9 & 112.7 & 114.3 & 113.3 & 108.6 & 109.7 \\
\hline Paraguay & 102.7 & 106.3 & 113.0 & 106.2 & 118.4 & 106.3 & 95.8 & 85.1 & 93.6 & 90.5 \\
\hline Peru & 98.2 & 95.9 & 99.9 & 100.0 & 101.1 & 104.0 & 104.1 & 100.4 & 98.6 & 94.1 \\
\hline Dominican Republic $^{f}$ & 96.5 & 98.6 & 131.4 & 125.6 & 90.4 & 96.3 & 96.5 & 98.9 & 102.7 & 95.8 \\
\hline Trinidad and Tobago & 94.5 & 90.2 & 90.9 & 93.1 & 92.0 & 90.2 & 88.6 & 84.1 & 77.7 & 76.7 \\
\hline Uruguay & 101.3 & 117.6 & 149.9 & 152.3 & 134.0 & 128.4 & 127.7 & 121.0 & 118.1 & 100.8 \\
\hline Venezuela (Bolivarian Republic of) & 95.3 & 125.1 & 141.2 & 139.0 & 142.2 & 132.5 & 118.7 & 96.8 & 73.4 & 117.9 \\
\hline
\end{tabular}

Source: Economic Commission for Latin America and the Caribbean (ECLAC), on the basis of official figures from the International Monetary Fund (IMF) and national sources.

a Annual averages. A country's overall real effective exchange rate index is calculated by weighting its real bilateral exchange rate indices with each of its trading partners by each partner's share in the country's total trade flows in terms of exports and imports. The extraregional real effective exchange rate index excludes trade with other Latin American and Caribbean countries. A currency depreciates in real effective terms when this index rises and appreciates when it falls.

Preliminary figures, weighted by trade in 2008 .

January-May average.

Simple average of the extraregional real effective exchange rate for 20 countries. It excludes Barbados and Dominica.

Preliminary figures. Yearly calculation by ECLAC, based on consumer price data and nominal exchange rates provided by the National Statistical Office of Cuba Owing to lack of data, the period 2002-2010 has been weighted using trade figures for 2001 
Table A-20

LATIN AMERICA AND THE CARIBBEAN: PARTICIPATION RATE

(Average annual rates)

\begin{tabular}{|c|c|c|c|c|c|c|c|c|c|c|c|}
\hline & & & 2001 & 2002 & 2003 & 2004 & 2005 & 2006 & 2007 & 2008 & $2009^{a}$ \\
\hline $\begin{array}{l}\text { Latin America and } \\
\text { the Caribbean }{ }^{b}\end{array}$ & & $\begin{array}{l}\text { Total } \\
\text { Female } \\
\text { Male }\end{array}$ & $\begin{array}{l}59.7 \\
45.7 \\
74.4\end{array}$ & $\begin{array}{l}59.5 \\
45.6 \\
74.1\end{array}$ & $\begin{array}{l}59.7 \\
46.6 \\
73.6\end{array}$ & $\begin{array}{l}59.9 \\
46.7 \\
73.9\end{array}$ & $\begin{array}{l}60.0 \\
47.0 \\
73.7\end{array}$ & $\begin{array}{l}60.0 \\
47.2 \\
73.6\end{array}$ & $\begin{array}{l}60.8 \\
48.0 \\
74.6\end{array}$ & $\begin{array}{l}61.2 \\
48.6 \\
74.7\end{array}$ & $\begin{array}{l}61.5 \\
49.1 \\
74.8\end{array}$ \\
\hline Argentina $^{c}$ & Urban areas & $\begin{array}{l}\text { Total } \\
\text { Female } \\
\text { Male }\end{array}$ & $\begin{array}{l}56.0 \\
42.6 \\
71.4\end{array}$ & $\begin{array}{l}55.8 \\
43.3 \\
70.3\end{array}$ & $\begin{array}{l}60.1 \\
49.2 \\
72.9\end{array}$ & $\begin{array}{l}60.3 \\
49.0 \\
73.2\end{array}$ & $\begin{array}{l}59.9 \\
48.3 \\
73.2\end{array}$ & $\begin{array}{l}60.3 \\
49.0 \\
73.3\end{array}$ & $\begin{array}{l}59.5 \\
47.7 \\
73.0\end{array}$ & $\begin{array}{l}58.8 \\
47.2 \\
72.0\end{array}$ & $\begin{array}{l}59.3 \\
48.0 \\
72.1\end{array}$ \\
\hline $\begin{array}{l}\text { Bolivia (Plurinational } \\
\text { State of) }\end{array}$ & National total & $\begin{array}{l}\text { Total } \\
\text { Female } \\
\text { Male }\end{array}$ & $\begin{array}{l}67.8 \\
60.1 \\
75.9\end{array}$ & $\begin{array}{l}64.6 \\
56.3 \\
73.2\end{array}$ & $\begin{array}{l}67.6 \\
60.1 \\
75.4\end{array}$ & $\begin{array}{l}64.9 \\
57.2 \\
73.3\end{array}$ & $\begin{array}{l}62.8 \\
54.8 \\
71.5\end{array}$ & $\begin{array}{l}66.3 \\
58.7 \\
74.2\end{array}$ & $\begin{array}{l}64.8 \\
56.2 \\
74.2\end{array}$ & $\begin{array}{l}\ldots \\
\ldots \\
\ldots\end{array}$ & $\begin{array}{l}\ldots \\
\ldots \\
\ldots\end{array}$ \\
\hline Brazil $^{c}$ & Six metropolitan areas & $\begin{array}{l}\text { Total } \\
\text { Female } \\
\text { Male }\end{array}$ & $\begin{array}{l}56.4 \\
43.9 \\
71.0\end{array}$ & $\begin{array}{l}56.7 \\
43.9 \\
70.5\end{array}$ & $\begin{array}{l}57.1 \\
47.8 \\
67.7\end{array}$ & $\begin{array}{l}57.2 \\
48.3 \\
67.3\end{array}$ & $\begin{array}{l}56.6 \\
47.7 \\
66.7\end{array}$ & $\begin{array}{l}56.9 \\
48.1 \\
66.8\end{array}$ & $\begin{array}{l}56.9 \\
48.5 \\
66.5\end{array}$ & $\begin{array}{l}57.0 \\
48.7 \\
66.5\end{array}$ & $\begin{array}{l}56.7 \\
48.6 \\
66.0\end{array}$ \\
\hline Chile & National total & $\begin{array}{l}\text { Total } \\
\text { Female } \\
\text { Male }\end{array}$ & $\begin{array}{l}53.9 \\
35.0 \\
73.4\end{array}$ & $\begin{array}{l}53.7 \\
35.0 \\
73.0\end{array}$ & $\begin{array}{l}54.4 \\
36.6 \\
73.0\end{array}$ & $\begin{array}{l}55.0 \\
38.1 \\
72.3\end{array}$ & $\begin{array}{l}55.6 \\
39.2 \\
72.6\end{array}$ & $\begin{array}{l}54.8 \\
38.5 \\
71.7\end{array}$ & $\begin{array}{l}54.9 \\
39.1 \\
71.4\end{array}$ & $\begin{array}{l}56.0 \\
40.9 \\
71.8\end{array}$ & $\begin{array}{l}55.9 \\
41.3 \\
71.0\end{array}$ \\
\hline Colombia & $\begin{array}{l}\text { Thirteen metropolitan } \\
\text { areas }\end{array}$ & $\begin{array}{l}\text { Total } \\
\text { Female } \\
\text { Male }\end{array}$ & $\begin{array}{l}64.4 \\
55.5 \\
74.6\end{array}$ & $\begin{array}{l}64.8 \\
55.3 \\
74.7\end{array}$ & $\begin{array}{l}65.0 \\
56.9 \\
74.2\end{array}$ & $\begin{array}{l}63.6 \\
54.9 \\
73.3\end{array}$ & $\begin{array}{l}63.3 \\
54.9 \\
72.8\end{array}$ & $\begin{array}{l}62.0 \\
53.5 \\
71.6\end{array}$ & $\begin{array}{l}61.8 \\
53.5 \\
71.2\end{array}$ & $\begin{array}{l}62.6 \\
54.0 \\
72.1\end{array}$ & $\begin{array}{l}64.6 \\
56.6 \\
73.5\end{array}$ \\
\hline Costa Rica & National total & $\begin{array}{l}\text { Total } \\
\text { Female } \\
\text { Male }\end{array}$ & $\begin{array}{l}55.8 \\
38.6 \\
73.7\end{array}$ & $\begin{array}{l}55.4 \\
38.2 \\
73.2\end{array}$ & $\begin{array}{l}55.5 \\
38.5 \\
73.3\end{array}$ & $\begin{array}{l}54.4 \\
36.8 \\
72.9\end{array}$ & $\begin{array}{l}56.8 \\
40.4 \\
73.9\end{array}$ & $\begin{array}{l}56.6 \\
40.7 \\
73.5\end{array}$ & $\begin{array}{l}57.0 \\
41.6 \\
73.2\end{array}$ & $\begin{array}{l}56.7 \\
41.7 \\
72.5\end{array}$ & $\begin{array}{l}56.5 \\
42.1 \\
71.5\end{array}$ \\
\hline Cuba $^{d}$ & National total & $\begin{array}{l}\text { Total } \\
\text { Female } \\
\text { Male }\end{array}$ & $\begin{array}{l}70.9 \\
53.7 \\
86.7\end{array}$ & $\begin{array}{l}71.0 \\
53.9 \\
86.6\end{array}$ & $\begin{array}{l}70.9 \\
54.2 \\
86.0\end{array}$ & $\begin{array}{l}71.0 \\
54.4 \\
86.1\end{array}$ & $\begin{array}{l}72.1 \\
55.6 \\
87.0\end{array}$ & $\begin{array}{l}72.1 \\
56.7 \\
86.0\end{array}$ & $\begin{array}{l}73.7 \\
59.3 \\
86.7\end{array}$ & $\begin{array}{l}74.7 \\
60.2 \\
87.8\end{array}$ & $\begin{array}{l}75.4 \\
61.0 \\
88.4\end{array}$ \\
\hline Ecuador & Urban total & $\begin{array}{l}\text { Total } \\
\text { Female } \\
\text { Male }\end{array}$ & $\begin{array}{l}63.1 \\
52.5 \\
74.0\end{array}$ & $\begin{array}{l}58.3 \\
46.7 \\
70.2\end{array}$ & $\begin{array}{l}58.2 \\
47.0 \\
69.8\end{array}$ & $\begin{array}{l}59.1 \\
47.9 \\
70.8\end{array}$ & $\begin{array}{l}59.5 \\
48.6 \\
70.9\end{array}$ & $\begin{array}{l}59.1 \\
47.7 \\
71.2\end{array}$ & $\begin{array}{l}61.3 \\
50.9 \\
72.5\end{array}$ & $\begin{array}{l}60.1 \\
49.6 \\
71.3\end{array}$ & $\begin{array}{l}58.9 \\
48.4 \\
70.0\end{array}$ \\
\hline El Salvador ${ }^{\mathrm{e}}$ & National total & $\begin{array}{l}\text { Total } \\
\text { Female } \\
\text { Male }\end{array}$ & $\begin{array}{l}53.3 \\
39.5 \\
69.2\end{array}$ & $\begin{array}{l}51.2 \\
38.6 \\
65.8\end{array}$ & $\begin{array}{l}53.4 \\
40.4 \\
68.3\end{array}$ & $\begin{array}{l}51.7 \\
38.6 \\
66.5\end{array}$ & $\begin{array}{l}52.4 \\
39.5 \\
67.4\end{array}$ & $\begin{array}{l}52.6 \\
40.4 \\
67.0\end{array}$ & $\begin{array}{l}62.1 \\
46.7 \\
81.0\end{array}$ & $\begin{array}{l}62.7 \\
47.3 \\
81.4\end{array}$ & $\begin{array}{l}62.8 \\
47.6 \\
81.0\end{array}$ \\
\hline Honduras & National total & $\begin{array}{l}\text { Total } \\
\text { Female } \\
\text { Male }\end{array}$ & $\begin{array}{l}52.5 \\
34.7 \\
71.8\end{array}$ & $\begin{array}{l}51.7 \\
32.5 \\
72.3\end{array}$ & $\begin{array}{l}50.0 \\
33.0 \\
68.4\end{array}$ & $\begin{array}{l}50.6 \\
32.7 \\
70.0\end{array}$ & $\begin{array}{l}50.9 \\
33.2 \\
70.0\end{array}$ & $\begin{array}{l}50.7 \\
33.5 \\
69.7\end{array}$ & $\begin{array}{l}50.7 \\
33.3 \\
70.1\end{array}$ & $\begin{array}{l}51.0 \\
34.4 \\
69.3\end{array}$ & $\begin{array}{l}53.1 \\
35.9 \\
72.3\end{array}$ \\
\hline Jamaica $^{f}$ & National total & $\begin{array}{l}\text { Total } \\
\text { Female } \\
\text { Male }\end{array}$ & $\begin{array}{l}63.0 \\
53.6 \\
73.0\end{array}$ & $\begin{array}{l}65.8 \\
57.3 \\
74.7\end{array}$ & $\begin{array}{l}64.4 \\
55.4 \\
73.7\end{array}$ & $\begin{array}{l}64.3 \\
55.8 \\
73.3\end{array}$ & $\begin{array}{l}64.2 \\
55.5 \\
73.3\end{array}$ & $\begin{array}{l}64.7 \\
56.4 \\
73.5\end{array}$ & $\begin{array}{l}64.8 \\
56.5 \\
73.6\end{array}$ & $\begin{array}{l}65.4 \\
57.3 \\
73.9\end{array}$ & $\begin{array}{l}63.8 \\
55.9 \\
72.0\end{array}$ \\
\hline Mexico & Urban areas & $\begin{array}{l}\text { Total } \\
\text { Female } \\
\text { Male }\end{array}$ & $\begin{array}{l}58.1 \\
40.9 \\
77.3\end{array}$ & $\begin{array}{l}57.8 \\
40.6 \\
76.9\end{array}$ & $\begin{array}{l}58.3 \\
41.5 \\
76.8\end{array}$ & $\begin{array}{l}58.9 \\
42.9 \\
76.7\end{array}$ & $\begin{array}{l}59.5 \\
44.1 \\
76.9\end{array}$ & $\begin{array}{l}60.7 \\
45.8 \\
77.6\end{array}$ & $\begin{array}{l}60.7 \\
46.2 \\
77.3\end{array}$ & $\begin{array}{l}60.4 \\
46.1 \\
76.7\end{array}$ & $\begin{array}{l}60.2 \\
46.4 \\
75.8\end{array}$ \\
\hline Nicaragua & National total & $\begin{array}{l}\text { Total } \\
\text { Female } \\
\text { Male }\end{array}$ & $\begin{array}{l}57.5 \\
40.2 \\
75.6\end{array}$ & $\begin{array}{l}\ldots \\
\ldots \\
\cdots\end{array}$ & $\begin{array}{r}53.7 \\
\ldots \\
\ldots\end{array}$ & $\begin{array}{r}53.1 \\
\ldots \\
\ldots\end{array}$ & $\begin{array}{l}53.8 \\
39.4 \\
69.2\end{array}$ & $\begin{array}{r}51.4 \\
\ldots \\
\ldots\end{array}$ & $\begin{array}{r}53.4 \\
\ldots \\
\ldots\end{array}$ & $\begin{array}{r}53.3 \\
\ldots \\
\ldots\end{array}$ & $\begin{array}{r}51.8 \\
\ldots \\
\ldots\end{array}$ \\
\hline Panama & National total & $\begin{array}{l}\text { Total } \\
\text { Female } \\
\text { Male }\end{array}$ & $\begin{array}{l}60.5 \\
41.7 \\
79.5\end{array}$ & $\begin{array}{l}62.6 \\
45.1 \\
80.1\end{array}$ & $\begin{array}{l}62.8 \\
45.9 \\
79.9\end{array}$ & $\begin{array}{l}63.3 \\
46.6 \\
80.6\end{array}$ & $\begin{array}{l}63.6 \\
47.4 \\
80.3\end{array}$ & $\begin{array}{l}62.6 \\
45.8 \\
79.9\end{array}$ & $\begin{array}{l}62.7 \\
46.8 \\
79.3\end{array}$ & $\begin{array}{l}63.9 \\
47.2 \\
81.5\end{array}$ & $\begin{array}{l}64.1 \\
48.3 \\
80.9\end{array}$ \\
\hline Paraguay & National total & $\begin{array}{l}\text { Total } \\
\text { Female } \\
\text { Male }\end{array}$ & $\begin{array}{l}59.2 \\
45.5 \\
73.3\end{array}$ & $\begin{array}{l}61.2 \\
45.8 \\
76.9\end{array}$ & $\begin{array}{l}59.8 \\
45.7 \\
74.3\end{array}$ & $\begin{array}{l}63.4 \\
50.4 \\
76.6\end{array}$ & $\begin{array}{l}61.8 \\
48.6 \\
75.1\end{array}$ & $\begin{array}{l}60.1 \\
46.1 \\
74.0\end{array}$ & $\begin{array}{l}60.8 \\
48.0 \\
73.9\end{array}$ & $\begin{array}{l}61.7 \\
47.9 \\
75.8\end{array}$ & $\begin{array}{l}\cdots \\
\cdots \\
\ldots\end{array}$ \\
\hline Peru & Metropolitan Lima & $\begin{array}{l}\text { Total } \\
\text { Female } \\
\text { Male }\end{array}$ & $\begin{array}{l}65.5 \\
55.9 \\
76.1\end{array}$ & $\begin{array}{l}62.9 \\
51.8 \\
75.3\end{array}$ & $\begin{array}{l}63.2 \\
54.2 \\
72.9\end{array}$ & $\begin{array}{l}62.3 \\
49.9 \\
75.6\end{array}$ & $\begin{array}{l}62.5 \\
52.3 \\
73.4\end{array}$ & $\begin{array}{l}64.0 \\
53.4 \\
75.4\end{array}$ & $\begin{array}{l}63.5 \\
51.7 \\
76.1\end{array}$ & $\begin{array}{l}66.4 \\
56.4 \\
77.0\end{array}$ & $\begin{array}{l}68.5 \\
57.9 \\
80.0\end{array}$ \\
\hline Dominican Republic & National total & $\begin{array}{l}\text { Total } \\
\text { Female } \\
\text { Male }\end{array}$ & $\begin{array}{l}54.3 \\
40.0 \\
69.2\end{array}$ & $\begin{array}{l}55.1 \\
42.1 \\
68.3\end{array}$ & $\begin{array}{l}54.7 \\
41.0 \\
68.6\end{array}$ & $\begin{array}{l}56.3 \\
43.7 \\
69.2\end{array}$ & $\begin{array}{l}55.9 \\
43.1 \\
68.8\end{array}$ & $\begin{array}{l}56.0 \\
43.6 \\
68.6\end{array}$ & $\begin{array}{l}56.1 \\
43.2 \\
69.3\end{array}$ & $\begin{array}{l}55.6 \\
43.5 \\
67.9\end{array}$ & $\begin{array}{l}53.8 \\
40.3 \\
67.4\end{array}$ \\
\hline Uruguay & Urban total & $\begin{array}{l}\text { Total } \\
\text { Female } \\
\text { Male }\end{array}$ & $\begin{array}{l}60.8 \\
51.0 \\
72.2\end{array}$ & $\begin{array}{l}59.3 \\
49.4 \\
70.7\end{array}$ & $\begin{array}{l}58.1 \\
48.9 \\
69.0\end{array}$ & $\begin{array}{l}58.5 \\
48.7 \\
70.0\end{array}$ & $\begin{array}{l}58.5 \\
49.5 \\
69.3\end{array}$ & $\begin{array}{l}60.9 \\
51.9 \\
71.7\end{array}$ & $\begin{array}{l}62.7 \\
53.7 \\
73.6\end{array}$ & $\begin{array}{l}62.6 \\
54.3 \\
72.7\end{array}$ & $\begin{array}{l}63.4 \\
55.2 \\
73.2\end{array}$ \\
\hline $\begin{array}{l}\text { Venezuela (Bolivarian } \\
\text { Republic of) }\end{array}$ & National total & $\begin{array}{l}\text { Total } \\
\text { Female } \\
\text { Male }\end{array}$ & $\begin{array}{l}66.5 \\
50.9 \\
82.0\end{array}$ & $\begin{array}{l}68.7 \\
54.3 \\
83.5\end{array}$ & $\begin{array}{l}69.3 \\
55.5 \\
83.0\end{array}$ & $\begin{array}{l}68.5 \\
54.5 \\
82.6\end{array}$ & $\begin{array}{l}66.3 \\
51.5 \\
81.2\end{array}$ & $\begin{array}{l}65.4 \\
50.6 \\
80.4\end{array}$ & $\begin{array}{l}64.9 \\
50.0 \\
79.9\end{array}$ & $\begin{array}{l}64.9 \\
50.1 \\
79.9\end{array}$ & $\begin{array}{l}65.3 \\
51.1 \\
79.6\end{array}$ \\
\hline
\end{tabular}

Source: Economic Commission for Latin America and the Caribbean (ECLAC), on the basis of official figures.

a Preliminary figures.

The data relating to the different countries are not comparable owing to differences in coverage and in the definition of the working age population. The regional series are simple averages of national data (excluding Nicaragua and the Plurinational State of Bolivia) and include adjustments for lack of information and changes in methodology. New measurements have been used since 2003; the data are not comparable with the previous series.

d In Cuba, the working-age population is measured as follows: for males, 17 to 59 years and for females, 15 to 54 years.

e New measurements have been used since 2007; the data are not comparable with the previous series.

New measurements have been used since 2002; the data are not comparable with the previous series. 
Table A-21

LATIN AMERICA AND THE CARIBBEAN: OPEN URBAN UNEMPLOYMENT

(Average annual rates)

\begin{tabular}{|c|c|c|c|c|c|c|c|c|c|c|}
\hline & & 2001 & 2002 & 2003 & 2004 & 2005 & 2006 & 2007 & 2008 & $2009^{a}$ \\
\hline Latin America and the Caribbean ${ }^{b}$ & & 10.2 & 11.1 & 11.0 & 10.3 & 9.1 & 8.6 & 7.9 & 7.3 & 8.2 \\
\hline Argentina $^{c}$ & Urban areas & 17.4 & 19.7 & 17.3 & 13.6 & 11.6 & 10.2 & 8.5 & 7.9 & 8.7 \\
\hline Bahamas ${ }^{d}$ & National total & 6.9 & 9.1 & 10.8 & 10.2 & 10.2 & 7.6 & 7.9 & 8.7 & 14.2 \\
\hline Barbados $^{d}$ & National total & 9.9 & 10.3 & 11.0 & 9.8 & 9.1 & 8.7 & 7.4 & 8.1 & 10.0 \\
\hline Belize $^{d}$ & National total & 9.1 & 10.0 & 12.9 & 11.6 & 11.0 & 9.4 & 8.5 & 8.2 & 13.1 \\
\hline Bolivia (Plurinational State of) & Urban total & 8.5 & 8.7 & 9.2 & 6.2 & 8.1 & 8.0 & 7.7 & 6.7 & 7.9 \\
\hline Brazil ${ }^{e}$ & Six metropolitan areas & 6.2 & 11.7 & 12.3 & 11.5 & 9.8 & 10.0 & 9.3 & 7.9 & 8.1 \\
\hline Chile & National total & 9.9 & 9.8 & 9.5 & 10.0 & 9.2 & 7.7 & 7.1 & 7.8 & 9.7 \\
\hline Colombia $^{d}$ & Thirteen metropolitan areas & 18.2 & 18.1 & 17.1 & 15.8 & 14.3 & 13.1 & 11.4 & 11.5 & 13.0 \\
\hline Costa Rica & Urban total & 5.8 & 6.8 & 6.7 & 6.7 & 6.9 & 6.0 & 4.8 & 4.8 & 7.6 \\
\hline Cuba & National total & 4.1 & 3.3 & 2.3 & 1.9 & 1.9 & 1.9 & 1.8 & 1.6 & 1.7 \\
\hline Ecuador $^{d}$ & Urban total $^{f}$ & 10.4 & 8.6 & 9.8 & 9.7 & 8.5 & 8.1 & 7.4 & 6.9 & 8.5 \\
\hline El Salvador ${ }^{\mathrm{g}}$ & Urban total & 7.0 & 6.2 & 6.2 & 6.5 & 7.3 & 5.7 & 5.8 & 5.5 & 7.1 \\
\hline Guatemala & Urban total & & 5.4 & 5.2 & 4.4 & & $\ldots$ & $\ldots$ & $\ldots$ & \\
\hline Honduras & Urban total & 5.9 & 6.1 & 7.6 & 8.0 & 6.5 & 4.9 & 4.0 & 4.1 & 4.9 \\
\hline Jamaica $^{\text {de }}$ & National total & 15.0 & 14.2 & 11.4 & 11.7 & 11.3 & 10.3 & 9.8 & 10.6 & 11.4 \\
\hline Mexico & Urban areas & 3.6 & 3.9 & 4.6 & 5.3 & 4.7 & 4.6 & 4.8 & 4.9 & 6.7 \\
\hline Nicaragua & Urban total & 11.3 & 11.6 & 10.2 & 9.3 & 7.0 & 7.0 & 6.9 & 8.0 & 10.5 \\
\hline Panama $^{d}$ & Urban total & 17.0 & 16.5 & 15.9 & 14.1 & 12.1 & 10.4 & 7.8 & 6.5 & 7.9 \\
\hline Paraguay & Urban total & 10.8 & 14.7 & 11.2 & 10.0 & 7.6 & 8.9 & 7.2 & 7.4 & \\
\hline Peru & Metropolitan Lima & 9.3 & 9.4 & 9.4 & 9.4 & 9.6 & 8.5 & 8.4 & 8.4 & 8.4 \\
\hline Dominican Republic ${ }^{d}$ & National total & 15.6 & 16.1 & 16.7 & 18.4 & 17.9 & 16.2 & 15.6 & 14.1 & 14.9 \\
\hline Suriname & National total & 14.0 & 10.0 & 7.0 & 8.4 & 11.2 & 12.1 & & & \\
\hline Trinidad and Tobago ${ }^{d}$ & National total & 10.8 & 10.4 & 10.5 & 8.4 & 8.0 & 6.2 & 5.6 & 4.6 & 5.3 \\
\hline Uruguay & Urban total & 15.3 & 17.0 & 16.9 & 13.1 & 12.2 & 11.4 & 9.6 & 7.9 & 7.7 \\
\hline Venezuela (Bolivarian Republic of) & National total & 13.3 & 15.8 & 18.0 & 15.3 & 12.4 & 10.0 & 8.4 & 7.3 & 7.8 \\
\hline
\end{tabular}

Source: Economic Commission for Latin America and the Caribbean (ECLAC), on the basis of official figures.

a Preliminary figures.

b The data for Argentina and Brazil have been adjusted to reflect changes in methodology in 2003 and 2002, respectively.

c New measurements have been used since 2003; the data are not comparable with the previous series.

d New measurements have been usec

e New measurements have been used since 2002; the data are not comparable with the previous series.

Up to 2003, the figures refer to Cuenca, Guayaquil and Quito.

9 New measurements have been used since 2007; the data are not comparable with the previous series.

Table A-22

LATIN AMERICA AND THE CARIBBEAN: EMPLOYMENT RATE a

(Average annual rates)

\begin{tabular}{|c|c|c|c|c|c|c|c|c|c|c|}
\hline & & 2001 & 2002 & 2003 & 2004 & 2005 & 2006 & 2007 & 2008 & $2009^{b}$ \\
\hline Latin America and the Caribbean ${ }^{c}$ & & 52.5 & 52.1 & 52.5 & 53.1 & 53.6 & 54.2 & 54.8 & 55.1 & 54.6 \\
\hline Argentina $^{d}$ & Urban areas & 47.4 & 45.9 & 49.8 & 52.0 & 52.9 & 54.1 & 54.5 & 54.2 & 54.2 \\
\hline Barbados & National total & 62.7 & 61.4 & 61.6 & 62.7 & 63.2 & 61.9 & 62.7 & 62.1 & 60.3 \\
\hline Bolivia (Plurinational State of) & Urban total & 55.4 & 53.0 & 54.9 & 55.0 & 51.2 & 54.0 & 52.7 & & \\
\hline Brazil $^{d}$ & Six metropolitan areas & 52.9 & 48.7 & 50.1 & 50.6 & 51.0 & 51.2 & 51.6 & 52.5 & 52.1 \\
\hline Chile & National total & 48.6 & 48.4 & 49.3 & 49.5 & 50.4 & 50.5 & 51.0 & 51.7 & 50.5 \\
\hline Colombia & Thirteen metropolitan areas & 52.7 & 53.2 & 54.1 & 53.7 & 54.3 & 53.9 & 54.8 & 55.3 & 56.2 \\
\hline Costa Rica & National total & 52.4 & 51.8 & 51.8 & 50.9 & 53.0 & 53.3 & 54.4 & 53.9 & 52.1 \\
\hline Cuba & National total & 68.0 & 68.6 & 69.2 & 69.7 & 70.7 & 70.7 & 72.4 & 73.6 & 74.2 \\
\hline Ecuador & Urban total & 56.2 & 52.9 & 51.5 & 53.5 & 54.4 & 54.3 & 56.8 & 56.0 & 53.9 \\
\hline El Salvador ${ }^{e}$ & National total & 49.8 & 48.0 & 49.7 & 48.2 & 48.3 & 49.2 & 58.1 & 59.0 & 58.2 \\
\hline Honduras & National total & 50.3 & 49.7 & 47.4 & 48.6 & 48.6 & 49.0 & 49.2 & 49.4 & 51.5 \\
\hline Jamaica $^{f}$ & National total & 53.5 & 56.4 & 57.1 & 56.8 & 57.0 & 58.0 & 58.6 & 58.5 & 56.3 \\
\hline Mexico & Urban areas & 56.0 & 55.5 & 55.6 & 55.8 & 56.7 & 57.9 & 57.8 & 57.5 & 56.2 \\
\hline Nicaragua & National total & 51.0 & $\ldots$ & 49.5 & 49.6 & 50.8 & 48.8 & 48.6 & 50.1 & 47.6 \\
\hline Panama & National total & 52.0 & 54.1 & 54.6 & 55.9 & 57.3 & 57.2 & 58.7 & 60.3 & 59.9 \\
\hline Paraguay & National total & 54.7 & 54.6 & 55.0 & 58.8 & 58.2 & 55.4 & 57.4 & 58.2 & \\
\hline Peru & Metropolitan Lima & 60.5 & 62.0 & 61.1 & 61.6 & 60.7 & 61.8 & 63.0 & 62.4 & 62.7 \\
\hline Dominican Republic & National total & 45.8 & 46.2 & 45.4 & 46.0 & 45.9 & 46.9 & 47.4 & 47.7 & 45.8 \\
\hline Trinidad and Tobago & National total & 53.8 & 54.6 & 55.2 & 57.8 & 58.6 & 59.9 & 59.9 & 60.6 & 59.4 \\
\hline Uruguay & Urban total & 51.4 & 49.1 & 48.3 & 50.9 & 51.4 & 53.9 & 56.7 & 57.7 & 58.5 \\
\hline Venezuela (Bolivarian Republic of) & National total & 57.6 & 57.8 & 56.8 & 58.1 & 58.1 & 58.9 & 59.5 & 60.2 & 60.2 \\
\hline
\end{tabular}

Source: Economic Commission for Latin America and the Caribbean (ECLAC), on the basis of official figures.

a Employed population as a percentage of the working-age population.

b Preliminary figures.

Weighted average adjusted for lack of information and changes in methodology.

d New measurements have been used since 2003; the data are not comparable with the previous series

e New measurements have been used since 2007; the data are not comparable with the 
Table A-23

LATIN AMERICA AND THE CARIBBEAN: FORMAL EMPLOYMENT INDICATORS

(Indices 2000=100)

\begin{tabular}{|c|c|c|c|c|c|c|c|c|c|}
\hline & 2001 & 2002 & 2003 & 2004 & 2005 & 2006 & 2007 & 2008 & $2009^{a}$ \\
\hline Argentina $^{\mathrm{b}}$ & 101,0 & 93,1 & 96,2 & 107,0 & 118,7 & 128,9 & 139,6 & 148,8 & 148,2 \\
\hline Brazil $^{c}$ & 102,9 & 101,6 & 104,2 & 109,5 & 115,7 & 121,3 & 127,5 & 135,6 & 138,5 \\
\hline Chile $^{b}$ & 101,6 & 103,4 & 105,9 & 109,6 & 118,2 & 125,7 & 135,8 & 145,7 & 147,4 \\
\hline Costa Rica $^{d}$ & 97,6 & 104,0 & 106,9 & 110,9 & 116,1 & 123,9 & 134,4 & 144,3 & 143,4 \\
\hline El Salvador ${ }^{d}$ & 101,7 & 100,9 & 102,5 & 104,9 & 108,6 & 113,9 & 119,8 & 123,3 & 119,3 \\
\hline Guatemala $^{d}$ & 102,2 & 104,9 & 105,5 & 108,9 & 110,4 & 113,0 & 118,2 & 118,1 & 119,9 \\
\hline Jamaica $^{\mathrm{e}}$ & 98,0 & 97,4 & 96,3 & 97,9 & 99,0 & 100,0 & 101,4 & 103,4 & 102,4 \\
\hline Mexico $^{d}$ & 99,5 & 98,6 & 98,2 & 99,6 & 102,8 & 107,7 & 112,2 & 114,5 & 102,4 \\
\hline Nicaragua ${ }^{d}$ & 101,8 & 101,0 & 103,7 & 112,9 & 123,2 & 136,2 & 148,8 & 159,9 & 163,6 \\
\hline Panama $^{\dagger}$ & 95,5 & 89,7 & 95,7 & 99,4 & 108,5 & 115,9 & 132,3 & 136,7 & 142,0 \\
\hline Peru ${ }^{e}$ & 98,1 & 98,1 & 99,8 & 102,5 & 107,1 & 115,0 & 124,3 & 134,7 & 136,5 \\
\hline Uruguay $^{g}$ & 97,7 & 92,1 & 93,9 & 99,8 & 110,7 & 120,5 & 130,9 & 141,0 & 145,2 \\
\hline
\end{tabular}

Source: Economic Commission for Latin America and the Caribbean (ECLAC), on the basis of official figures.

a Preliminary figures.

b Dependent workers paying into pension schemes.

Workers covered by social and labour legislation.

Workers with social security coverage.

Workers of medium-sized and large firms.

Private-sector workers with social security coverage. From 2008 on, refers to workers in small, medium-sized and large businesses in manufacturing, commerce and services.

Table A-24

LATIN AMERICA: VISIBLE UNDEREMPLOYMENT BY HOURS

(Percentages of employed workers)

\begin{tabular}{|c|c|c|c|c|c|c|c|c|c|}
\hline & 2001 & 2002 & 2003 & 2004 & 2005 & 2006 & 2007 & 2008 & $2009^{\circ}$ \\
\hline Argentina $^{b}$ & 18.9 & 24.0 & 20.7 & 17.5 & 14.2 & 12.5 & 10.4 & 9.5 & 11.1 \\
\hline Brazil $^{c}$ & $\ldots$ & 4.1 & 5.0 & 4.6 & 3.7 & 4.1 & 3.6 & 3.1 & 3.1 \\
\hline Chile $^{d}$ & 7.1 & 6.2 & 6.5 & 8.4 & 8.5 & 8.5 & 8.0 & 9.0 & 10.8 \\
\hline Colombia $^{e}$ & 16.3 & 16.8 & 15.3 & 15.2 & 13.8 & 11.9 & 10.0 & 9.1 & 9.5 \\
\hline Costa Rica $^{f}$ & 11.3 & 12.3 & 15.2 & 14.4 & 14.6 & 13.5 & 11.5 & 10.5 & 11.9 \\
\hline Ecuador $\mathrm{g}$ & 12.6 & 10.2 & 9.8 & 8.1 & 7.3 & 6.3 & 11.3 & 10.6 & 11.8 \\
\hline El Salvador ${ }^{h}$ & 3.8 & 4.3 & 4.8 & 4.5 & 6.2 & 4.9 & 5.3 & 6.3 & 7.7 \\
\hline Honduras $^{i}$ & 3.8 & 4.7 & 5.9 & 6.5 & 6.9 & 5.4 & 4.3 & 3.5 & 4.2 \\
\hline Mexico $^{j}$ & $\ldots$ & $\ldots$ & $\ldots$ & $\ldots$ & 7.5 & 6.9 & 7.2 & 6.9 & 9.3 \\
\hline Panama ${ }^{k}$ & $\ldots$ & $\ldots$ & $\ldots$ & 4.4 & 4.6 & 3.4 & 2.7 & 2.1 & 2.1 \\
\hline Paraguay' & 8.3 & 9.5 & 8.8 & 8.3 & 7.5 & 5.6 & 5.8 & 6.6 & $\ldots$ \\
\hline Peru ${ }^{m}$ & 12.8 & 11.8 & 9.8 & 9.6 & 9.5 & 9.4 & 9.5 & 8.9 & 9.3 \\
\hline Uruguay ${ }^{k}$ & 15.3 & 18.4 & 19.3 & 15.8 & 17.1 & 13.6 & 12.9 & 10.8 & 9.1 \\
\hline
\end{tabular}

Source: Economic Commission for Latin America and the Caribbean (ECLAC), on the basis of official figures.

Preliminary figures.

b Employed persons who work less than 35 hours per week and wish to work more hours; total urban areas.

c Employed persons who work less than 40 hours per week and wish to work more hours; six metropolitan areas.

d Employed persons who work less than 35 hours per week and who wish to work more; national total; third quarter of each year. The figures up to 2005 and since 2006 are not directly comparable since the sample changed.

Employed persons who work less than 48 hours per week and wish to work more hours; 13 metropolitan areas.

Employed persons who work less than 47 hours per week and wish to work more hours; national total.

9 Employed persons who work less than 40 hours per week and wish to work more hours. Up to 2006, Cuenca, Guayaquil and Quito; since 2007, urban national.

Employed persons who work less than 40 hours per week and wish to work more hours; total urban areas. New measurements have been used since 2007; the data are not comparable with the previous series.

Employed persons who work less than 36 hours per week and wish to work more hours; total urban areas.

Employed workers wishing to work more than their current job permits, national total.

Employed workers wishing to work more than their current job permits, national total.

Employed persons who work less than 30 hours per week and wish to work more hours; total urban areas.

$\mathrm{m}$ Employed persons who work less than 35 hours per week and wish to work more hours; Metropolitan Lima. 
Table A-25

LATIN AMERICA AND THE CARIBBEAN: REAL AVERAGE WAGES

(Average annual Index, 2000=100)

\begin{tabular}{|c|c|c|c|c|c|c|c|c|c|}
\hline & 2001 & 2002 & 2003 & 2004 & 2005 & 2006 & 2007 & 2008 & $2009^{a}$ \\
\hline Argentina $^{b}$ & 98.8 & 79.6 & 89.3 & 97.5 & 104.8 & 114.1 & 124.5 & 135.4 & 151.3 \\
\hline Bolivia (Plurinational State of) ${ }^{c}$ & 105.8 & 109.3 & 111.1 & 114.1 & 110.0 & 101.2 & 98.4 & $\ldots$ & $\ldots$ \\
\hline Brazil ${ }^{d}$ & 95.1 & 93.1 & 84.9 & 85.5 & 85.2 & 88.2 & 89.5 & 91.4 & 92.6 \\
\hline Chile $^{e}$ & 101.7 & 103.7 & 104.6 & 106.5 & 108.5 & 110.6 & 113.7 & 113.5 & 118.9 \\
\hline Colombia ${ }^{b}$ & 99.7 & 102.7 & 102.0 & 103.7 & 105.3 & 109.3 & 109.0 & 106.9 & 108.0 \\
\hline Costa Rica $^{f}$ & 101.0 & 105.1 & 105.5 & 102.8 & 100.8 & 102.4 & 103.8 & 101.7 & 109.5 \\
\hline Cuba & 96.2 & 105.1 & 107.8 & 114.6 & 129.5 & 144.5 & 142.3 & 142.5 & 148.3 \\
\hline El Salvadorg & 95.1 & 94.4 & 93.5 & 90.3 & 88.2 & 88.5 & 86.4 & 83.7 & 86.6 \\
\hline Guatemala $^{f}$ & 100.5 & 99.6 & 100.0 & 97.8 & 93.9 & 92.9 & 91.4 & 89.0 & 89.1 \\
\hline Mexico $^{b}$ & $\ldots$ & 108.7 & 110.1 & 110.4 & 110.7 & 112.3 & 113.4 & 115.9 & 116.6 \\
\hline Nicaragua $^{f}$ & 101.0 & 104.5 & 106.7 & 104.3 & 104.4 & 106.7 & 104.4 & 100.2 & 106.0 \\
\hline Panama $^{h}$ & 98.8 & 95.8 & 95.3 & 94.5 & 93.4 & 95.3 & 96.5 & 95.9 & 95.5 \\
\hline Paraguay & 101.4 & 96.3 & 95.6 & 97.2 & 98.2 & 98.8 & 101.1 & 100.4 & 104.9 \\
\hline Peru $^{i}$ & 99.1 & 103.7 & 105.3 & 106.5 & 104.4 & 105.7 & 103.8 & 106.1 & $106.4^{j}$ \\
\hline Uruguay & 99.7 & 89.0 & 77.9 & 77.9 & 81.5 & 85.0 & 89.0 & 92.2 & 98.9 \\
\hline Venezuela (Bolivarian Republic of) & 106.9 & 95.1 & 78.4 & 78.6 & 80.7 & 84.8 & 85.8 & 81.9 & 76.5 \\
\hline
\end{tabular}

Source: Economic Commission for Latin America and the Caribbean (ECLAC), on the basis of official figures.

a Preliminary figures.

Manufacturing. From 2005, registered private-sector workers.

Private-sector average wage index

Workers covered by social and labour legislation. Since 2003, private sector only.

General index of hourly wages.

Average wages declared by workers covered by social securit $y$.

Gross salary.

Average wages declared by workers covered by social security. From 2008 on, refers to workers in small, medium-sized and large businesses in manufacturing, commerce and services.

Private sector workers in the Lima metropolitan area.

Estimate based on data for June.

Table A-26

LATIN AMERICA AND THE CARIBBEAN: REAL MINIMUM WAGE (Indices 2000=100)

\begin{tabular}{|c|c|c|c|c|c|c|c|c|c|}
\hline & 2001 & 2002 & 2003 & 2004 & 2005 & 2006 & 2007 & 2008 & $2009^{a}$ \\
\hline Argentina & 101.1 & 81.3 & 84.0 & 129.8 & 171.1 & 193.2 & 219.6 & 253.3 & 292.1 \\
\hline Bolivia (Plurinational State of) & 110.8 & 116.0 & 116.9 & 112.0 & 106.3 & 111.1 & 109.7 & 108.0 & 116.9 \\
\hline Brazil & 109.8 & 114.3 & 117.4 & 121.4 & 128.5 & 145.3 & 154.8 & 160.8 & 172.7 \\
\hline Chile & 103.8 & 106.8 & 108.3 & 111.3 & 113.4 & 116.3 & 118.5 & 118.3 & 124.7 \\
\hline Colombia & 101.2 & 101.9 & 102.0 & 103.8 & 105.0 & 107.9 & 108.6 & 106.9 & 110.2 \\
\hline Costa Rica & 100.2 & 99.5 & 99.2 & 97.6 & 97.8 & 99.5 & 100.8 & 99.5 & 103.3 \\
\hline Cuba & 89.6 & 94.3 & 92.4 & 94.4 & 206.6 & 196.6 & 183.6 & 180.6 & 182.8 \\
\hline Ecuador & 111.5 & 112.5 & 119.3 & 122.2 & 125.9 & 130.0 & 135.1 & 146.7 & 152.0 \\
\hline El Salvador & 96.4 & 94.6 & 96.7 & 95.3 & 91.1 & 90.5 & 92.7 & 92.9 & 101.7 \\
\hline Guatemala & 108.3 & 108.6 & 117.3 & 117.6 & 115.9 & 119.6 & 117.7 & 105.7 & 111.1 \\
\hline Haiti & 88.4 & 80.5 & 107.5 & 91.7 & 79.6 & 70.2 & 64.8 & 56.4 & 72.2 \\
\hline Honduras & 102.5 & 104.6 & 113.6 & 114.5 & 121.2 & 127.4 & 130.9 & 131.1 & 223.5 \\
\hline Mexico & 100.4 & 101.2 & 100.4 & 99.1 & 99.0 & 99.0 & 98.3 & 96.2 & 94.8 \\
\hline Nicaragua & 102.1 & 105.9 & 109.2 & 113.5 & 118.1 & 128.5 & 131.6 & 141.6 & 165.5 \\
\hline Panama & 107.0 & 105.8 & 106.5 & 107.5 & 104.5 & 108.1 & 106.3 & 109.2 & 106.5 \\
\hline Paraguay & 103.7 & 102.9 & 105.8 & 102.4 & 104.4 & 106.7 & 103.9 & 101.3 & 102.0 \\
\hline Peru & 101.2 & 101.0 & 102.2 & 106.9 & 105.1 & 112.0 & 111.7 & 114.5 & 111.2 \\
\hline Dominican Republic & 105.7 & 105.1 & 95.5 & 81.2 & 96.4 & 89.6 & 93.8 & 87.7 & 93.9 \\
\hline Uruguay & 98.7 & 88.7 & 77.7 & 77.5 & 131.9 & 153.2 & 159.6 & 176.9 & 194.3 \\
\hline Venezuela (Bolivarian Republic of) & 100.0 & 94.5 & 83.3 & 92.7 & 103.7 & 113.9 & 114.4 & 107.1 & 99.4 \\
\hline
\end{tabular}

Source: Economic Commission for Latin America and the Caribbean (ECLAC), on the basis of official figures.

a Preliminary figures. 
Table A-27

LATIN AMERICA AND THE CARIBBEAN: MONETARY BASE

(End-of-year balances as percentages of GDP)

\begin{tabular}{|c|c|c|c|c|c|c|c|c|c|}
\hline & 2001 & 2002 & 2003 & 2004 & 2005 & 2006 & 2007 & 2008 & 2009 \\
\hline Antigua and Barbuda & 13.3 & 13.7 & 16.4 & 15.7 & 15.6 & 14.8 & 13.2 & 12.1 & 13.2 \\
\hline Argentina & 4.5 & 9.3 & 12.3 & 11.7 & 10.3 & 12.2 & 12.2 & 10.6 & 10.4 \\
\hline Bahamas & 7.3 & 7.9 & 8.2 & 10.6 & 9.0 & 8.1 & 9.1 & 8.8 & 9.4 \\
\hline Barbados & 12.7 & 18.3 & 20.1 & 13.7 & 12.9 & 13.0 & 16.1 & 16.0 & 15.8 \\
\hline Belize & 11.9 & 10.3 & 10.3 & 10.9 & 11.5 & 13.3 & 13.2 & 14.1 & 16.1 \\
\hline Bolivia (Plurinational State of) & 8.3 & 8.2 & 8.5 & 8.3 & 10.2 & 12.2 & 16.9 & 18.5 & 24.3 \\
\hline Brazil & 4.1 & 5.0 & 4.3 & 4.6 & 4.7 & 5.1 & 5.5 & 4.9 & 5.3 \\
\hline Chile & 4.2 & 4.2 & 4.1 & 4.1 & 4.4 & 4.5 & 4.3 & 4.8 & 5.2 \\
\hline Colombia & 5.1 & 5.7 & 6.0 & 6.3 & 6.7 & 7.0 & 7.5 & 7.8 & 7.8 \\
\hline Costa Rica & 5.4 & 5.2 & 5.7 & 5.9 & 6.4 & 6.7 & 7.6 & 7.3 & 7.2 \\
\hline Cuba & 32.2 & 32.5 & 27.8 & 31.6 & 31.6 & 26.0 & 23.6 & 31.1 & \\
\hline Dominica & 12.7 & 18.9 & 17.7 & 15.2 & 15.1 & 17.2 & 16.8 & 13.1 & 14.8 \\
\hline Ecuador & $\ldots$ & $\ldots$ & $\ldots$ & $\ldots$ & $\ldots$ & $\ldots$ & 10.0 & 11.3 & 13.3 \\
\hline El Salvador & 11.8 & 9.9 & 11.6 & 10.4 & 9.8 & 9.2 & 10.2 & 10.4 & 10.8 \\
\hline Grenada & 15.9 & 18.2 & 18.1 & 25.9 & 16.9 & 17.2 & 18.4 & 15.7 & 16.4 \\
\hline Guatemala & 9.5 & 10.0 & 9.8 & 10.0 & 10.2 & 11.1 & 10.9 & 9.7 & 10.4 \\
\hline Guyana & 15.3 & 16.4 & 17.3 & 17.4 & 18.5 & 17.3 & 15.5 & 15.5 & 17.5 \\
\hline Haiti & 19.9 & 22.0 & 24.0 & 22.7 & 21.1 & 20.4 & 20.3 & 21.0 & 22.2 \\
\hline Honduras & 8.3 & 8.5 & 8.4 & 9.1 & 8.9 & 9.6 & 11.3 & 11.4 & 10.5 \\
\hline Jamaica & 8.2 & 7.6 & 7.5 & 7.3 & 7.1 & 7.4 & 7.3 & 7.0 & 7.4 \\
\hline Mexico & 3.5 & 3.8 & 4.0 & 4.0 & 4.1 & 4.3 & 4.4 & 4.8 & 5.4 \\
\hline Nicaragua & 6.1 & 6.3 & 7.3 & 7.5 & 7.8 & 8.8 & 9.5 & 8.6 & 9.9 \\
\hline Panama & 0.9 & 6.0 & 6.0 & 5.6 & 5.2 & 4.9 & 5.1 & 4.4 & 5.2 \\
\hline Paraguay & 8.4 & 8.8 & 9.7 & 9.8 & 9.2 & 9.2 & 10.5 & 10.3 & 14.4 \\
\hline Peru & 3.2 & 3.4 & 3.5 & 3.9 & 4.5 & 4.6 & 5.3 & 5.9 & 6.0 \\
\hline Dominican Republic & 9.3 & 8.3 & 12.5 & 8.7 & 9.1 & 9.0 & 9.0 & 8.5 & 8.2 \\
\hline Saint Kitts and Nevis & 16.6 & 18.9 & 16.7 & 19.6 & 16.3 & 18.3 & 18.7 & 17.8 & 24.3 \\
\hline Saint Vincent and the Grenadines & 18.2 & 15.4 & 15.3 & 14.9 & 14.4 & 14.5 & 15.5 & 14.5 & 11.7 \\
\hline Saint Lucia & 13.3 & 13.3 & 14.2 & 15.7 & 12.9 & 13.4 & 14.1 & 14.4 & 15.7 \\
\hline Suriname & 24.8 & 21.1 & 15.4 & 17.4 & 15.2 & 17.2 & 19.5 & 17.6 & 24.4 \\
\hline Trinidad and Tobago & 8.8 & 8.1 & 6.6 & 5.7 & 7.0 & 7.2 & 7.0 & 8.6 & 13.9 \\
\hline Uruguay & 3.9 & 4.1 & 4.3 & 4.0 & 5.0 & 4.5 & 5.6 & 5.5 & 5.5 \\
\hline Venezuela (Bolivarian Republic of) & 7.3 & 7.1 & 8.4 & 7.8 & 7.6 & 11.4 & 13.2 & 12.5 & 14.1 \\
\hline
\end{tabular}

Source: Economic Commission for Latin America and the Caribbean (ECLAC), on the basis of official figures. 
Table A-28

LATIN AMERICA AND THE CARIBBEAN: MONEY SUPPLY (M3) a

(End-of-year balances as percentages of GDP)

\begin{tabular}{|c|c|c|c|c|c|c|c|c|c|}
\hline & 2001 & 2002 & 2003 & 2004 & 2005 & 2006 & 2007 & 2008 & 2009 \\
\hline Antigua and Barbuda & 83.2 & 87.2 & 101.4 & 98.6 & 100.3 & 95.5 & 93.6 & 91.8 & 100.3 \\
\hline Argentina & 24.9 & 21.9 & 24.9 & 24.7 & 25.8 & 25.8 & 26.1 & 22.4 & 24.1 \\
\hline Bahamas & 65.3 & 65.9 & 65.9 & 71.8 & 71.9 & 72.3 & 75.9 & 80.7 & 81.3 \\
\hline Barbados & 83.2 & 96.8 & 95.1 & 105.1 & 108.1 & 110.8 & 118.6 & 118.9 & 120.2 \\
\hline Belize & 59.7 & 57.0 & 55.7 & 59.1 & 59.6 & 62.0 & 68.0 & 72.4 & 78.6 \\
\hline Bolivia (Plurinational State of) & 52.9 & 49.4 & 47.7 & 42.3 & 43.0 & 42.4 & 47.8 & 46.5 & 58.7 \\
\hline Brazil $^{b}$ & 24.7 & 26.9 & 24.3 & 25.4 & 27.1 & 27.9 & 29.4 & 35.7 & 37.1 \\
\hline Chile & 54.2 & 54.6 & 48.8 & 50.3 & 53.3 & 53.2 & 58.1 & 69.0 & 64.4 \\
\hline Colombia $^{c}$ & 27.4 & 27.1 & 27.4 & 28.7 & 30.6 & 31.8 & 33.4 & 35.4 & 35.2 \\
\hline Costa Rica & 33.8 & 36.3 & 37.1 & 42.6 & 44.0 & 44.3 & 43.8 & 46.8 & 49.5 \\
\hline Cuba $^{d}$ & 39.0 & 40.6 & 37.7 & 38.0 & 46.6 & 38.6 & 37.2 & 41.9 & $\ldots$ \\
\hline Dominica & 76.5 & 87.7 & 90.9 & 87.7 & 86.7 & 90.3 & 90.8 & 87.2 & 95.5 \\
\hline Ecuador & $\ldots$ & $\ldots$ & $\ldots$ & $\ldots$ & $\ldots$ & $\ldots$ & 26.1 & 34.2 & 38.1 \\
\hline El Salvador & 44.9 & 42.0 & 40.2 & 39.2 & 36.9 & 37.8 & 40.9 & 42.4 & 45.0 \\
\hline Grenada & 99.7 & 104.2 & 101.7 & 125.6 & 101.4 & 99.6 & 102.3 & 95.7 & 109.2 \\
\hline Guatemala & 32.1 & 31.7 & 33.5 & 34.0 & 35.7 & 38.3 & 37.0 & 35.2 & 37.6 \\
\hline Guyana & 43.7 & 44.5 & 46.3 & 46.0 & 47.2 & 49.2 & 46.4 & 47.0 & 48.9 \\
\hline Haiti & 38.7 & 45.4 & 47.8 & 42.5 & 42.1 & 38.5 & 37.3 & 38.1 & 39.3 \\
\hline Honduras & 44.9 & 46.5 & 47.2 & 49.2 & 50.8 & 55.0 & 56.6 & 52.6 & 51.6 \\
\hline Jamaica & 34.9 & 35.2 & 33.8 & 34.1 & 33.2 & 32.6 & 33.6 & 30.8 & 29.6 \\
\hline Mexico & 43.3 & 44.4 & 45.6 & 45.0 & 48.5 & 49.3 & 50.2 & 54.5 & 59.4 \\
\hline Nicaragua & 37.4 & 40.0 & 41.8 & 43.0 & 41.3 & 39.9 & 41.9 & 38.2 & 43.1 \\
\hline Panama & 85.6 & 80.9 & 79.5 & 78.3 & 78.0 & 86.1 & 87.5 & 84.5 & $\ldots$ \\
\hline Paraguay & 35.3 & 31.9 & 29.1 & 28.3 & 27.5 & 26.8 & 30.0 & 31.3 & 39.8 \\
\hline Peru & 26.1 & 26.1 & 24.7 & 24.0 & 25.8 & 24.3 & 26.8 & 29.9 & 30.4 \\
\hline Dominican Republic & 37.9 & 35.7 & 49.8 & 39.1 & 37.3 & 33.8 & 34.5 & 31.4 & 33.4 \\
\hline Saint Kitts and Nevis & 93.8 & 96.6 & 100.4 & 111.1 & 107.5 & 110.4 & 117.2 & 107.2 & 123.0 \\
\hline Saint Vincent and the Grenadines & 76.7 & 77.2 & 75.5 & 77.4 & 76.5 & 72.6 & 70.6 & 68.2 & 68.0 \\
\hline Saint Lucia & 70.4 & 71.1 & 72.8 & 73.3 & 77.6 & 85.7 & 89.1 & 92.6 & 97.0 \\
\hline Suriname & 65.0 & 55.8 & 51.0 & 64.6 & 58.0 & 61.0 & 68.2 & 61.3 & 80.3 \\
\hline Trinidad and Tobago & 40.3 & 40.9 & 32.2 & 33.3 & 35.1 & 37.4 & 37.2 & 35.7 & $\ldots$ \\
\hline Uruguay & 91.6 & 87.7 & 81.1 & 66.0 & 59.1 & 57.1 & 49.5 & 56.2 & 49.6 \\
\hline Venezuela (Bolivarian Republic of) ${ }^{e}$ & 19.1 & 18.2 & 23.0 & 21.8 & 23.3 & 30.4 & 31.5 & 29.1 & 33.6 \\
\hline
\end{tabular}

Source: Economic Commission for Latin America and the Caribbean (ECLAC), on the basis of official figures.

According to the ECLAC definition, this corresponds to M1 plus savings and time deposits in national currency plus foreign currency deposits.

According to the country's definition, this corresponds to M1 plus special interest-bearing deposits, savings deposits and securities issued by deposit institutions.

According to the country's definition, this also includes deposits of entitites in liquidation and term deposit certificates of special entities and demand deposits of non-bank entities.

d Refers to M2 (M1 plus fixed-term deposits).

e Does not include foreign-currency deposits. 
Table A-29

LATIN AMERICA AND THE CARIBBEAN: FOREIGN CURRENCY DEPOSITS

(End-of-year balances as percentages of GDP)

\begin{tabular}{|c|c|c|c|c|c|c|c|c|c|}
\hline & 2001 & 2002 & 2003 & 2004 & 2005 & 2006 & 2007 & 2008 & 2009 \\
\hline Antigua and Barbuda & 5.5 & 7.6 & 9.0 & 7.8 & 8.3 & 8.6 & 10.8 & 8.3 & 13.7 \\
\hline Argentina & 16.5 & 0.7 & 1.4 & 1.7 & 2.0 & 2.3 & 2.6 & 2.7 & 3.4 \\
\hline Bahamas & 1.6 & 1.6 & 1.7 & 1.6 & 2.2 & 2.3 & 2.7 & 2.8 & 3.1 \\
\hline Barbados & 8.3 & 12.5 & 10.7 & 10.7 & 16.4 & 11.3 & 19.8 & 14.8 & 11.3 \\
\hline Bolivia (Plurinational State of) & 45.0 & 41.7 & 39.4 & 33.1 & 30.9 & 26.7 & 23.9 & 20.3 & 24.4 \\
\hline Chile & 6.3 & 5.9 & 5.4 & 4.9 & 4.7 & 4.7 & 4.8 & 9.0 & 7.1 \\
\hline Costa Rica & 14.7 & 16.0 & 16.2 & 21.6 & 21.7 & 20.8 & 18.1 & 22.0 & 23.9 \\
\hline Dominica & 2.2 & 3.2 & 6.1 & 3.7 & 1.4 & 1.4 & 1.1 & 1.5 & 1.4 \\
\hline Grenada & 6.6 & 6.8 & 7.4 & 7.2 & 7.1 & 5.3 & 7.8 & 6.9 & 8.1 \\
\hline Guatemala & 1.4 & 2.0 & 2.8 & 3.7 & 3.9 & 4.3 & 4.7 & 4.8 & 5.9 \\
\hline Haiti & 13.1 & 17.6 & 20.0 & 16.6 & 18.0 & 15.9 & 15.8 & 16.7 & 18.2 \\
\hline Honduras ${ }^{a}$ & 11.7 & 12.4 & 12.5 & 13.6 & 13.4 & 13.8 & 14.0 & 13.9 & 13.8 \\
\hline Jamaica & 8.7 & 9.8 & 11.1 & 11.3 & 10.5 & 9.6 & 10.9 & 10.1 & 9.8 \\
\hline Mexico & 1.7 & 1.5 & 1.2 & 1.4 & 1.5 & 1.4 & 1.3 & 1.4 & 1.6 \\
\hline Nicaragua & 25.0 & 27.9 & 28.4 & 28.6 & 27.8 & 26.1 & 27.4 & 26.1 & 30.2 \\
\hline Paraguay & 19.9 & 18.4 & 14.8 & 13.1 & 11.7 & 10.6 & 10.7 & 12.1 & 14.1 \\
\hline Peru & 17.4 & 17.1 & 15.3 & 13.2 & 14.1 & 12.4 & 12.4 & 14.0 & 13.4 \\
\hline Dominican Republic ${ }^{b}$ & 5.8 & 7.5 & 9.6 & 6.6 & 7.3 & 6.5 & 6.5 & 6.1 & 6.3 \\
\hline Saint Kitts and Nevis & 25.7 & 25.3 & 27.4 & 29.5 & 29.0 & 31.9 & 32.9 & 25.9 & 26.4 \\
\hline Saint Vincent and the Grenadines & 1.0 & 1.1 & 1.0 & 2.4 & 1.2 & 2.4 & 2.7 & 2.3 & 1.9 \\
\hline Saint Lucia & 1.4 & 1.3 & 1.6 & 1.9 & 2.7 & 8.8 & 5.8 & 6.0 & 5.6 \\
\hline Suriname & 25.4 & 21.7 & 23.9 & 31.7 & 27.6 & 29.2 & 32.6 & 28.4 & 36.8 \\
\hline Trinidad and Tobago & 9.1 & 9.8 & 6.0 & 8.4 & 7.3 & 9.1 & 9.0 & 9.9 & $\ldots$ \\
\hline Uruguay & 81.5 & 78.8 & 71.6 & 57.1 & 48.5 & 45.8 & 36.9 & 43.6 & 36.3 \\
\hline
\end{tabular}

Source: Economic Commission for Latin America and the Caribbean (ECLAC), on the basis of official figures.

a Term deposits in foreign currency.

b Series corresponding to harmonized monetary indicators. 
Table A-30

LATIN AMERICA AND THE CARIBBEAN: DOMESTIC CREDIT TO THE PRIVATE SECTOR

(End-of-year balances as percentages of GDP)

\begin{tabular}{|c|c|c|c|c|c|c|c|c|c|}
\hline & 2001 & 2002 & 2003 & 2004 & 2005 & 2006 & 2007 & 2008 & $2009^{a}$ \\
\hline Antigua and Barbuda & 73.0 & 77.4 & 76.9 & 71.8 & 75.1 & 75.5 & 75.2 & 78.8 & 85.7 \\
\hline Argentina & 20.8 & 15.3 & 10.8 & 10.5 & 11.7 & 13.0 & 14.5 & 13.7 & 13.5 \\
\hline Bahamas & 67.8 & 69.1 & 66.9 & 69.8 & 73.3 & 78.8 & 83.8 & 89.1 & 89.1 \\
\hline Barbados & 51.0 & 55.7 & 51.4 & 58.4 & 68.1 & 72.5 & 72.2 & 77.4 & 71.5 \\
\hline Belize & 44.6 & 47.8 & 51.5 & 53.5 & 54.0 & 55.8 & 61.2 & 63.6 & 67.6 \\
\hline Bolivia (Plurinational State of) & 53.2 & 51.1 & 47.8 & 42.1 & 39.3 & 34.8 & 34.0 & 31.1 & 33.9 \\
\hline Brazil & 32.5 & 32.5 & 31.8 & 32.0 & 37.0 & 43.8 & 51.0 & 59.8 & 64.5 \\
\hline Chile & 65.6 & 65.9 & 62.7 & 62.3 & 64.3 & 63.7 & 69.7 & 79.3 & 69.2 \\
\hline Colombia & 21.0 & 19.4 & 19.1 & 19.0 & 19.9 & 23.1 & 26.1 & 27.6 & 26.0 \\
\hline Costa Rica & 23.5 & 25.4 & 26.5 & 26.7 & 29.4 & 31.1 & 36.5 & 41.7 & 40.4 \\
\hline Cuba $^{b}$ & $\ldots$ & $\ldots$ & $\ldots$ & $\ldots$ & 9.2 & 15.0 & 21.0 & 24.1 & $\ldots$ \\
\hline Dominica & 62.3 & 63.9 & 60.2 & 59.5 & 60.1 & 63.2 & 60.8 & 60.5 & 64.5 \\
\hline Ecuador & 26.6 & 20.9 & 19.9 & 21.1 & 23.0 & 23.9 & 25.0 & 26.4 & 27.9 \\
\hline El Salvador & 40.2 & 44.5 & 42.3 & 42.1 & 41.9 & 42.3 & 42.1 & 40.8 & 40.5 \\
\hline Grenada & 81.2 & 80.6 & 75.9 & 81.2 & 74.5 & 81.6 & 86.5 & 87.2 & 100.5 \\
\hline Guatemala & 20.6 & 20.0 & 20.4 & 20.9 & 23.2 & 27.1 & 29.9 & 29.0 & 29.0 \\
\hline Guyana & 27.2 & 26.6 & 21.2 & 19.4 & 19.9 & 21.2 & 20.8 & 22.8 & 22.8 \\
\hline Haiti & 15.6 & 18.4 & 17.7 & 15.4 & 15.7 & 14.4 & 14.2 & 14.9 & 16.4 \\
\hline Honduras & 36.7 & 36.1 & 37.7 & 38.5 & 39.7 & 45.2 & 52.8 & 52.1 & 52.6 \\
\hline Jamaica & 8.3 & 10.0 & 12.5 & 13.3 & 14.1 & 15.8 & 18.2 & 20.4 & 19.3 \\
\hline Mexico & 12.9 & 14.3 & 14.0 & 13.2 & 14.4 & 16.8 & 18.4 & 17.3 & 18.6 \\
\hline Nicaragua & 17.7 & 19.6 & 22.9 & 25.4 & 29.3 & 34.1 & 39.9 & 38.3 & 34.3 \\
\hline Panama & 108.6 & 90.4 & 87.1 & 85.1 & 87.1 & 88.4 & 90.6 & 89.4 & 87.1 \\
\hline Paraguay ${ }^{c}$ & -3.1 & -2.7 & -4.1 & -4.8 & -3.9 & -3.3 & -4.7 & -4.9 & -8.7 \\
\hline Peru & 30.4 & 30.1 & 28.7 & 27.0 & 28.7 & 28.6 & 33.1 & 33.6 & 35.5 \\
\hline Dominican Republic & 32.7 & 33.6 & 37.1 & 23.4 & 23.3 & 19.6 & 21.6 & 20.9 & 21.3 \\
\hline Saint Kitts and Nevis & 75.1 & 72.4 & 79.0 & 80.8 & 79.4 & 79.7 & 84.7 & 80.7 & 91.1 \\
\hline Saint Vincent and the Grenadines & 65.2 & 64.2 & 62.0 & 59.6 & 57.6 & 58.6 & 60.1 & 59.0 & 59.6 \\
\hline Saint Lucia & 93.5 & 92.8 & 85.1 & 86.3 & 92.2 & 104.5 & 129.1 & 138.2 & 145.4 \\
\hline Suriname & 16.9 & 18.3 & 19.7 & 25.2 & 25.5 & 27.7 & 32.7 & 35.3 & 42.4 \\
\hline Trinidad and Tobago & 28.3 & 30.0 & 25.9 & 26.6 & 26.8 & 27.1 & 28.6 & 26.4 & 30.8 \\
\hline Uruguay & 66.2 & 73.4 & 45.4 & 30.3 & 26.6 & 25.9 & 24.5 & 29.4 & 22.6 \\
\hline Venezuela (Bolivarian Republic of) & 11.6 & 9.6 & 8.6 & 10.7 & 12.7 & 16.5 & 23.1 & 21.1 & $\ldots$ \\
\hline
\end{tabular}

Source: Economic Commission for Latin America and the Caribbean (ECLAC), on the basis of official figures.

a Preliminary figures.

b Includes credit, services and agricultural production cooperative production units, private farmers and individuals.

c Credit granted to the private sector by the banking sector. 
Table A-31

LATIN AMERICA AND THE CARIBBEAN: REPRESENTATIVE LENDING RATES

(Annual average of annualized monthly rates)

\begin{tabular}{|c|c|c|c|c|c|c|c|c|c|}
\hline & 2001 & 2002 & 2003 & 2004 & 2005 & 2006 & 2007 & 2008 & 2009 \\
\hline Antigua and Barbuda ${ }^{a}$ & & $\ldots$ & $\ldots$ & 11.5 & 10.7 & 10.7 & 10.3 & 10.1 & 9.5 \\
\hline Argentina ${ }^{b}$ & 28.6 & 40.7 & 16.8 & 10.8 & 10.5 & 12.9 & 14.0 & 19.8 & 21.3 \\
\hline Bahamas $^{c}$ & $\ldots$ & $\ldots$ & 12.0 & 11.2 & 10.3 & 10.0 & 10.6 & 11.0 & 10.6 \\
\hline Barbados $^{d}$ & $\ldots$ & $\ldots$ & 7.6 & 7.4 & 8.5 & 10.0 & 10.4 & 9.7 & 8.7 \\
\hline Belize $^{e}$ & 15.5 & 14.8 & 14.4 & 13.9 & 14.2 & 14.2 & 14.3 & 14.2 & 14.1 \\
\hline Bolivia (Plurinational State of) ${ }^{f}$ & 13.7 & 10.9 & 9.1 & 8.2 & 8.2 & 7.8 & 8.2 & 8.9 & 8.3 \\
\hline Brazil ${ }^{g}$ & 41.1 & 44.4 & 49.8 & 41.1 & 43.7 & 40.0 & 34.5 & 38.8 & 40.4 \\
\hline Chile $^{h}$ & 16.7 & 14.4 & 13.0 & 11.0 & 13.5 & 14.4 & 13.6 & 15.2 & 12.9 \\
\hline Colombia $^{i}$ & 20.7 & 16.3 & 15.2 & 15.1 & 14.6 & 12.9 & 15.4 & 17.2 & 13.0 \\
\hline Costa Rica $^{j}$ & 26.7 & 26.8 & 26.2 & 23.4 & 24.0 & 22.7 & 17.3 & 16.7 & 21.6 \\
\hline Cuba ${ }^{k}$ & $\ldots$ & $\ldots$ & 9.6 & 9.7 & 9.8 & 9.4 & 9.1 & 9.0 & 9.3 \\
\hline Dominica $^{a}$ & $\ldots$ & $\ldots$ & $\ldots$ & 8.9 & 9.4 & 9.5 & 9.2 & 9.1 & 10.0 \\
\hline Ecuador ${ }^{1}$ & 15.5 & 14.1 & 12.6 & 10.2 & 8.7 & 8.9 & 10.1 & 9.8 & 9.2 \\
\hline El Salvador ${ }^{m}$ & 9.6 & 7.1 & 6.6 & 6.3 & 6.9 & 7.5 & 7.8 & 7.9 & 9.3 \\
\hline Grenada $^{a}$ & $\ldots$ & $\ldots$ & $\ldots$ & 10.3 & 9.8 & 9.8 & 9.7 & 9.4 & 10.7 \\
\hline Guatemala a $^{a}$ & 19.0 & 16.9 & 15.0 & 13.8 & 13.0 & 12.8 & 12.8 & 13.4 & 13.8 \\
\hline Guyana $^{d}$ & 17.3 & 17.3 & 16.6 & 16.6 & 15.1 & 14.9 & 14.1 & 13.9 & 14.0 \\
\hline Haiti $^{n}$ & 28.6 & 25.5 & 30.7 & 34.1 & 27.1 & 29.5 & 31.2 & 23.3 & 21.6 \\
\hline Honduras $^{a}$ & 23.8 & 22.7 & 20.8 & 19.9 & 18.8 & 17.4 & 16.6 & 17.9 & 19.4 \\
\hline Jamaica $^{\circ}$ & 29.4 & 26.1 & 25.1 & 25.1 & 23.2 & 22.0 & 22.0 & 22.3 & 22.6 \\
\hline Mexico $^{p}$ & 12.8 & 8.2 & 6.9 & 7.2 & 9.9 & 7.5 & 7.6 & 8.7 & 7.1 \\
\hline Nicaragua ${ }^{q}$ & 18.6 & 18.3 & 15.5 & 13.5 & 12.1 & 11.6 & 13.0 & 13.2 & 14.0 \\
\hline Panama ${ }^{r}$ & 10.6 & 9.2 & 8.9 & 8.2 & 8.2 & 8.1 & 8.3 & 8.2 & 8.3 \\
\hline Paraguay $^{s}$ & 28.3 & 34.3 & 30.5 & 21.2 & 15.3 & 16.6 & 14.6 & 14.6 & 15.6 \\
\hline Peru ${ }^{t}$ & 26.1 & 23.3 & 20.2 & 18.7 & 17.9 & 17.1 & 16.5 & 16.7 & 16.0 \\
\hline Dominican Republic $^{d}$ & 20.0 & 21.3 & 27.8 & 30.3 & 21.4 & 15.7 & 11.7 & 16.0 & 12.9 \\
\hline Saint Kitts and Nevis ${ }^{a}$ & $\ldots$ & $\ldots$ & $\ldots$ & 10.0 & 9.5 & 9.2 & 9.3 & 8.6 & 8.6 \\
\hline Saint Vincent and the Grenadines ${ }^{a}$ & $\ldots$ & $\ldots$ & $\ldots$ & 9.7 & 9.6 & 9.7 & 9.6 & 9.5 & 9.1 \\
\hline Saint Lucia ${ }^{a}$ & $\cdots$ & $\cdots$ & $\cdots$ & 10.8 & 10.3 & 10.5 & 9.9 & 9.3 & 9.0 \\
\hline Suriname $^{\circ}$ & 25.7 & 22.2 & 21.0 & 20.4 & 18.1 & 15.7 & 13.8 & 12.2 & 11.7 \\
\hline Trinidad and Tobago $^{d}$ & 15.6 & 13.4 & 11.0 & 9.4 & 9.1 & 10.2 & 10.5 & 12.3 & 12.5 \\
\hline Uruguay ${ }^{u}$ & 38.1 & 116.4 & 56.6 & 26.0 & 15.3 & 10.7 & 10.0 & 13.1 & 16.6 \\
\hline Venezuela (Bolivarian Republic of) ${ }^{\vee}$ & 24.8 & 38.4 & 25.7 & 17.3 & 15.6 & 14.6 & 16.7 & 22.8 & 20.6 \\
\hline
\end{tabular}

Source: Economic Commission for Latin America and the Caribbean (ECLAC), on the basis of official figures.

Weighted average lending rates.

Local-currency loans at fixed or renegotiable rates, signature loans of up to 89 days.

Interest rate on loans and overdrafts, weighted average.

Prime lending rate.

Rate for personal and business loans, residential and other construction; weighted average.

Nominal dollar rate for 60-91-day banking operations

Preset lending rate for legal persons.

Lending rate for 90-360-day periods, non-adjustable operations.

Total lending rate of the system (weighted average of all lending rates)

Average lending rate in the financial system.

Corporate lending rate in convertible pesos.

Benchmark dollar lending rate.

Basic lending rate for up to 1 year.

Average of minimum and maximum lending rates.

Average lending rate.

Lending rate published by the International Monetary Fund.

Weighted average of the weekly lending rate for loans in national currency in the system.

Interest rate on 1-year trade credit.

Weighted average of effective lending rates in national currency, not including overdrafts or credit cards.

Average lending rate, constant structure.

Business credit, 30-367 days.

Average rate for loan operations for the six major commercial banks. 
Table A-32

LATIN AMERICA AND THE CARIBBEAN: CONSUMER PRICES

(Percentage variation December - December)

\begin{tabular}{|c|c|c|c|c|c|c|c|c|c|c|}
\hline & 2001 & 2002 & 2003 & 2004 & 2005 & 2006 & 2007 & 2008 & 2009 & $2010^{a}$ \\
\hline Latin America and the Caribbean ${ }^{b}$ & 6.1 & 12.2 & 8.5 & 7.4 & 6.1 & 5.0 & 6.5 & 8.2 & 4.6 & 5.9 \\
\hline Antigua and Barbuda & $\cdots$ & $\ldots$ & $\ldots$ & 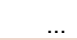 & $\ldots$ & 0.0 & 5.2 & 0.7 & 2.4 & $3.5^{c}$ \\
\hline Argentina & -1.5 & 41.0 & 3.7 & 6.1 & 12.3 & 9.8 & 8.5 & 7.2 & 7.7 & 10.7 \\
\hline Bahamas & 2.9 & 1.9 & 2.4 & 1.9 & 1.2 & 2.3 & 2.8 & 4.6 & 1.3 & $0.9^{\mathrm{c}}$ \\
\hline Barbados & -0.3 & 0.9 & 0.3 & 4.3 & 7.4 & 5.6 & 4.7 & 7.3 & 4.4 & $5.2^{d}$ \\
\hline Belize & & 3.2 & 2.3 & 3.1 & 4.2 & 2.9 & 4.1 & 4.4 & $\ldots$ & $\ldots$ \\
\hline Bolivia (Plurinational State of) & 0.9 & 2.4 & 3.9 & 4.6 & 4.9 & 4.9 & 11.7 & 11.8 & 0.3 & 1.4 \\
\hline Brazil & 7.7 & 12.5 & 9.3 & 7.6 & 5.7 & 3.1 & 4.5 & 5.9 & 4.3 & 5.2 \\
\hline Chile & 2.6 & 2.8 & 1.1 & 2.4 & 3.7 & 2.6 & 7.8 & 7.1 & -1.4 & 1.5 \\
\hline Colombia & 7.6 & 7.0 & 6.5 & 5.5 & 4.9 & 4.5 & 5.7 & 7.7 & 2.0 & 2.1 \\
\hline Costa Rica & 11.0 & 9.7 & 9.9 & 13.1 & 14.1 & 9.4 & 10.8 & 13.9 & 4.0 & 6.2 \\
\hline $\mathrm{Cuba}^{\mathrm{e}}$ & -1.4 & 7.3 & -3.8 & 2.9 & 3.7 & 5.7 & 10.6 & -0.1 & -0.1 & $\ldots$ \\
\hline Dominica & 1.1 & 0.5 & 2.8 & -7.2 & 2.7 & 1.8 & 6.0 & 2.0 & 3.3 & $4.2^{c}$ \\
\hline Ecuador & 22.4 & 9.3 & 6.1 & 1.9 & 3.1 & 2.9 & 3.3 & 8.8 & 4.3 & 3.2 \\
\hline El Salvador & 1.4 & 2.8 & 2.5 & 5.4 & 4.3 & 4.9 & 4.9 & 5.5 & -0.2 & 0.1 \\
\hline Grenada & $\begin{array}{l}1.4 \\
-0.7\end{array}$ & $\begin{array}{l}2.0 \\
2.3\end{array}$ & -7.1 & $\begin{array}{l}0.4 \\
2.5\end{array}$ & 6.2 & $\begin{array}{l}4.5 \\
1.7\end{array}$ & 7.4 & 5.2 & -2.4 & $3.9^{c}$ \\
\hline Guatemala & 8.9 & 6.3 & 5.9 & 9.2 & 8.6 & 5.8 & 8.7 & 9.4 & -0.3 & 3.5 \\
\hline Guyana & 1.5 & 6.0 & ... & & 8.2 & 4.2 & 14.1 & 6.4 & 3.7 & \\
\hline Haiti & 8.1 & 14.8 & 40.4 & 20.2 & 14.8 & 10.2 & 9.3 & 10.1 & 2.1 & $6.4^{f}$ \\
\hline Honduras & 8.8 & 8.1 & 6.8 & 9.2 & 7.7 & 5.3 & 8.9 & 10.8 & 3.0 & 4.4 \\
\hline Jamaica & 8.6 & 7.3 & 13.8 & 13.6 & 12.6 & 5.6 & 16.8 & 16.9 & 10.2 & 14.1 \\
\hline Mexico & 4.4 & 5.7 & 4.0 & 5.2 & 3.3 & 4.1 & 3.8 & 6.5 & 3.6 & 3.9 \\
\hline Nicaragua & & $\ldots$ & 6.7 & 8.9 & 9.7 & 10.2 & 16.2 & 12.7 & 1.8 & 5.4 \\
\hline Panama & 0.0 & 1.9 & 1.4 & -0.2 & 3.4 & 2.2 & 6.4 & 6.8 & 1.9 & 3.2 \\
\hline Paraguay & 8.4 & 14.6 & 9.3 & 2.8 & 9.9 & 12.5 & 6.0 & 7.5 & 1.9 & 4.5 \\
\hline Peru & -0.1 & 1.5 & 2.5 & 3.5 & 1.5 & 1.1 & 3.9 & 6.7 & 0.2 & 1.0 \\
\hline Dominican Republic & 4.4 & 10.5 & 42.7 & 28.7 & 7.4 & 5.0 & 8.9 & 4.5 & 5.8 & 7.9 \\
\hline Saint Kitts and Nevis & & & & & & 7.9 & 2.1 & 7.6 & 1.0 & $0.5^{\mathrm{c}}$ \\
\hline Saint Vincent and the Grenadines & 5.5 & -0.7 & 0.5 & 3.5 & 5.2 & 9.6 & 0.0 & 3.8 & 1.0 & $2.7^{d}$ \\
\hline Saint Lucia & -0.2 & 0.4 & 2.7 & ... & $\ldots$ & 4.8 & 8.3 & 8.7 & -1.6 & $-0.8^{d}$ \\
\hline Suriname & & $\ldots$ & $\ldots$ & $\begin{array}{l}\cdots \\
\cdots\end{array}$ & 15.8 & 4.7 & 8.3 & 9.4 & 1.3 & $3.1^{f}$ \\
\hline Trinidad and Tobago & 3.2 & 4.3 & 3.0 & 5.6 & 7.2 & 9.1 & 7.6 & 14.5 & 1.3 & $7.3^{f}$ \\
\hline Uruguay & 3.6 & 25.9 & 10.2 & 7.6 & 4.9 & 6.4 & 8.5 & 9.2 & 5.9 & 7.1 \\
\hline Venezuela (Bolivarian Republic of) & 12.3 & 31.2 & 27.1 & 19.2 & 14.4 & 17.0 & 22.5 & 31.9 & 26.9 & 32.0 \\
\hline
\end{tabular}

Source: Economic Commission for Latin America and the Caribbean (ECLAC), on the basis of official figures.

a Twelve-month variation to May 2010.

The only English-speaking Caribbean countries included are Barbados, Jamaica and Trinidad and Tobago.

Twelve-month variation to March 2010.

Twelve-month variation to February 2010.

Refers to national-currency markets.

Twelve-month variation to April 2010

Table A-33

LATIN AMERICA AND THE CARIBBEAN: WHOLESALE PRICES

(Percentage variation December - December)

\begin{tabular}{|c|c|c|c|c|c|c|c|c|c|c|c|}
\hline & & 2001 & 2002 & 2003 & 2004 & 2005 & 2006 & 2007 & 2008 & 2009 & $2010^{a}$ \\
\hline Argentina & WPI & -3.4 & 113.7 & 2.0 & 7.9 & 10.6 & 7.2 & 14.6 & 8.8 & 10.3 & 15.2 \\
\hline Brazil & IPA-Media & 11.9 & 33.6 & 7.6 & 15.1 & -1.0 & 4.4 & 9.2 & 10.8 & -4.4 & 3.4 \\
\hline Chile & WPI & 3.1 & 10.4 & -1.0 & 7.8 & 3.2 & 7.9 & 14.0 & 22.7 & -14.9 & -1.4 \\
\hline Colombia & PPI & 9.0 & 3.8 & 10.2 & 5.2 & 3.0 & 5.3 & 1.3 & 9.0 & -2.2 & 1.3 \\
\hline Costa Rica & IND-PPI & 8.6 & 8.4 & 11.0 & 17.7 & 12.1 & 13.7 & 14.6 & 23.5 & -1.2 & 0.7 \\
\hline Ecuador & PPI & -5.6 & 17.7 & 4.5 & 4.3 & 21.6 & 7.2 & 18.2 & -28.3 & 33.0 & 11.9 \\
\hline El Salvador & WPI & $\ldots$ & 0.3 & 2.6 & 6.8 & 7.5 & 3.9 & 10.8 & -6.9 & 2.7 & $4.8^{b}$ \\
\hline Mexico & NPPI & 1.3 & 9.2 & 6.8 & 8.0 & 3.4 & 7.3 & 5.4 & 7.8 & 4.1 & 3.9 \\
\hline Peru & WPI-NP & -2.2 & 1.7 & 2.0 & 4.9 & 3.6 & 1.3 & 5.2 & 8.8 & -5.1 & 2.0 \\
\hline Uruguay & PPI-NP & 3.8 & 64.6 & 20.5 & 5.1 & -2.2 & 8.2 & 16.1 & 6.4 & 10.5 & 4.7 \\
\hline Venezuela (Bolivarian Republic of) & WPI-VAT & 10.2 & 49.4 & 48.4 & 23.1 & 14.2 & 15.9 & 17.2 & 32.4 & 24.8 & 32.8 \\
\hline
\end{tabular}

Source: Economic Commission for Latin America and the Caribbean (ECLAC), on the basis of official figures.

a Twelve-month variation to May 2010.

Twelve-month variation to April 2010.

Abbreviations:

WPI:Wholesale price index; IPA-Media:Wholesale price index (acronym in Portuguese); PPI: Producer price index; IND-PPI: Industrial producer price index; NPPI: National producer price index; WPI-NP:Wholesale price index, national products; PPI-NP: Producer price index, national products; WPI-VAT: Wholesale price index, includes value added tax. 
Table A-34

LATIN AMERICA AND THE CARIBBEAN: PUBLIC-SECTOR BALANCE

(Percentages of GDP)

\begin{tabular}{|c|c|c|c|c|c|c|c|c|c|c|c|c|}
\hline & \multicolumn{6}{|c|}{ Central government } & \multicolumn{6}{|c|}{ Non-financial public sector } \\
\hline & \multicolumn{3}{|c|}{ Primary balance } & \multicolumn{3}{|c|}{ Overall balance } & \multicolumn{3}{|c|}{ Primary balance } & \multicolumn{3}{|c|}{ Overall balance } \\
\hline & 2007 & 2008 & $2009^{a}$ & 2007 & 2008 & $2009^{a}$ & 2007 & 2008 & $2009^{a}$ & 2007 & 2008 & $2009^{a}$ \\
\hline Latin America and the Caribbean (33 countries) ${ }^{b}$ & 2.1 & 1.3 & -0.6 & -0.5 & -1.3 & -3.4 & $\ldots$ & $\ldots$ & $\ldots$ & 1.1 & -0.3 & -3.6 \\
\hline Latin America and the Caribbean (19 countries) ${ }^{c}$ & 2.2 & 1.2 & -1.0 & 0.3 & -0.4 & -2.8 & 3.8 & 2.3 & $\ldots$ & 1.3 & 0.1 & -3.2 \\
\hline Caribbean (13 countries) ${ }^{d}$ & -3.1 & 2.0 & 0.3 & -1.6 & -2.1 & -4.0 & $\ldots$ & $\cdots$ & $\cdots$ & $\cdots$ & $\cdots$ & $\cdots$ \\
\hline Antigua and Barbuda & -3.1 & -3.6 & -9.0 & -6.4 & -6.8 & -10.6 & & & $\ldots$ & $\cdots$ & & $\ldots$ \\
\hline Argentina $^{\mathrm{e}}$ & 2.7 & 2.8 & 1.2 & 0.6 & 0.7 & -1.0 & 3.2 & 2.6 & $\ldots$ & 0.7 & 0.3 & $\ldots$ \\
\hline Bahamas & 0.6 & -1.1 & -0.9 & -1.3 & -3.3 & -3.2 & & & & & & \\
\hline Barbados & 2.7 & -0.8 & -3.2 & -1.8 & -6.4 & -9.2 & 2.7 & -0.8 & -3.2 & -1.8 & -6.4 & -9.2 \\
\hline Belize & 4.1 & 5.4 & 0.8 & -1.2 & 1.5 & -2.9 & & & & & & \\
\hline Bolivia (Plurinational state of) ${ }^{f}$ & 3.5 & 0.8 & 1.1 & 2.3 & -0.0 & 0.2 & 3.0 & 4.1 & 1.0 & -1.7 & 3.2 & 0.1 \\
\hline Brazil g & 2.2 & 2.4 & 1.3 & -1.9 & -1.2 & -3.6 & 3.5 & 3.5 & 2.1 & -2.8 & -1.9 & -3.3 \\
\hline Chile & 9.4 & 5.7 & -3.9 & 8.8 & 5.2 & -4.4 & 11.7 & 6.8 & $\ldots$ & 10.8 & 5.9 & \\
\hline Colombia $^{h}$ & 1.0 & 0.9 & -1.1 & -2.7 & -2.3 & -4.1 & 2.8 & $\ldots$ & $\ldots$ & -1.0 & 0.0 & -2.5 \\
\hline Costa Rica & 3.7 & 2.4 & -1.3 & 0.6 & 0.2 & -3.4 & 4.9 & 2.1 & -2.5 & 1.8 & -0.1 & -4.6 \\
\hline Cuba & -1.8 & -5.5 & -3.5 & -3.2 & -6.9 & -4.8 & $\ldots$ & $\ldots$ & $\ldots$ & $\ldots$ & $\ldots$ & $\ldots$ \\
\hline Dominica & 4.0 & -0.8 & -1.3 & 1.0 & -3.2 & -2.7 & & & & $\ldots$ & & \\
\hline Ecuador & 1.9 & 0.3 & -4.2 & -0.1 & -1.1 & -5.1 & 4.0 & 0.5 & -4.8 & 2.1 & -0.9 & -5.5 \\
\hline El Salvador & 2.2 & 1.7 & -1.2 & -0.2 & -0.6 & -3.7 & 0.5 & -0.7 & -3.0 & -1.9 & -3.1 & -5.6 \\
\hline Grenada & -4.6 & -4.2 & -3.5 & -6.6 & -6.1 & -6.2 & $\ldots$ & $\ldots$ & $\ldots$ & $\ldots$ & $\ldots$ & \\
\hline Guatemala & 0.0 & -0.3 & -1.7 & -1.4 & -1.6 & -3.2 & $\ldots$ & $\ldots$ & $\ldots$ & $\ldots$ & $\cdots$ & \\
\hline Guyana & -2.8 & -2.1 & -2.1 & -4.5 & -3.8 & -3.7 & $\ldots$ & $\ldots$ & $\ldots$ & $\ldots$ & $\ldots$ & \\
\hline Haiti & -1.3 & -1.0 & -0.8 & -1.6 & -1.3 & -1.3 & . & . & $\ldots$ & $\ldots$ & . & \\
\hline Honduras ${ }^{i}$ & -2.4 & -1.9 & -5.4 & -3.1 & -2.5 & -6.2 & 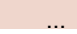 & 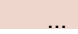 & & $\ldots$ & & \\
\hline Jamaica & 7.2 & 4.9 & 7.4 & -4.2 & -7.4 & -7.2 & & & & & & \\
\hline Mexico $^{j}$ & -0.5 & -0.2 & -0.5 & -2.0 & -1.6 & -2.2 & 1.9 & 1.6 & -0.4 & 0.0 & -0.1 & -2.3 \\
\hline Nicaragua & 2.0 & 0.0 & -0.9 & 0.4 & -1.2 & -2.3 & 2.8 & 0.5 & -0.1 & 1.3 & -0.8 & -1.5 \\
\hline Panama & 4.6 & 3.4 & 1.4 & 1.2 & 0.3 & -1.5 & 6.9 & 3.5 & 1.9 & 3.5 & 0.4 & -1.0 \\
\hline Paraguay & 1.8 & 3.1 & 0.7 & 1.0 & 2.5 & 0.1 & 3.9 & 4.0 & & 2.8 & 3.3 & \\
\hline Peru & 3.5 & 3.5 & -0.6 & 1.8 & 2.2 & -1.8 & 4.9 & 3.7 & -0.6 & 3.1 & 2.1 & -1.9 \\
\hline Dominican Republick & 1.4 & -1.9 & -1.5 & 0.1 & -3.5 & -3.4 & & & & $\ldots$ & & \\
\hline Saint Kitts and Nevis ${ }^{\prime}$ & 6.0 & 8.1 & 9.0 & -2.4 & -0.3 & 0.7 & & $\ldots$ & . & $\ldots$ & & \\
\hline Saint Vincent and the Grenadines & -0.6 & 2.2 & -0.1 & -3.6 & -0.8 & -3.1 & & & & $\ldots$ & & \\
\hline Saint Lucia & 0.9 & 3.0 & 1.0 & -2.2 & 0.1 & -2.5 & $\cdots$ & $\cdots$ & $\begin{array}{l}\cdots \\
\cdots\end{array}$ & $\cdots$ & $\begin{array}{l}\cdots \\
\cdots\end{array}$ & \\
\hline Suriname & 5.7 & 5.8 & 8.1 & 8.0 & 2.3 & 3.7 & & & & $\ldots$ & & \\
\hline Trinidad and Tobago & 7.1 & 9.2 & -3.0 & 5.1 & 7.4 & -5.6 & & & & $\ldots$ & & \\
\hline Uruguay & 2.1 & 1.7 & 1.3 & -1.6 & -1.1 & -1.5 & 3.6 & 1.5 & 1.2 & -0.1 & -1.3 & -1.6 \\
\hline Venezuela (Bolivarian Republic of) & 4.6 & 0.1 & -3.7 & 3.1 & -1.2 & -5.1 & -1.0 & -1.2 & -6.7 & -2.7 & -2.7 & -8.2 \\
\hline
\end{tabular}

Source: Economic Commission for Latin America and the Caribbean (ECLAC), on the basis of official figures.

Preliminary figures.

Simple averages of the figures for 33 countries.

Simple averages. Includes information on 19 countries of Latin America and the Caribbean: Argentina, Bolivarian Republic of Venezuela, Brazil, Chile, Colombia, Costa Rica, Dominican Republic, Ecuador, El Salvador, Guatemala, Haiti, Honduras, Mexico, Nicaragua, Panama, Paraguay, Peru, Plurinational State of Bolivia and Uruguay.

d Simple averages. Includes information on 13 Caribbean countries: Antigua and Barbuda, Bahamas, Barbados, Belize, Dominica, Grenada, Guyana, Jamaica, Saint Kitts and Nevis, Saint Vincent and the Grenadines, Saint Lucia, Suriname and Trinidad and Tobago. The simple average for the central government includes the primary balance and the overall balance of the non-financial public sector of Barbados.

The central government coverage corresponds to national public administration.

The central government coverage corresponds to general government.

The figures are derived from the primary balance based on the below-the-line criterion and nominal interest.

The figures are derived from the primary balance based on the below-the-line criterion and nominal interest.
The central government coverage corresponds to the central national government. The central government balance does not include the cost of financial restructuring

The central government coverage corresponds to the central national govern
The central government coverage corresponds to the central administration.

The central government coverage corresponds to the federal government. The coverage of the non-financial public sector refers to the public sector.

The overall balance includes the residue.

The central government coverage corresponds to the federal government. 
Table A-35

LATIN AMERICA AND THE CARIBBEAN: CENTRAL GOVERNMENT FISCAL REVENUE (Percentages of GDP)

\begin{tabular}{|c|c|c|c|c|c|c|c|c|c|}
\hline & \multicolumn{3}{|c|}{ Total revenue } & \multicolumn{3}{|c|}{ Current revenue } & \multicolumn{3}{|c|}{ Capital revenue } \\
\hline & 2007 & 2008 & $2009^{a}$ & 2007 & 2008 & $2009^{a}$ & 2007 & 2008 & $2009^{a}$ \\
\hline Latin America and the Caribbean (33 countries) ${ }^{b}$ & 25.0 & 25.1 & 24.4 & 23.6 & 23.6 & 23.1 & 0.3 & 0.4 & 0.3 \\
\hline Latin America and the Caribbean (19 countries) ${ }^{\mathrm{C}}$ & 19.5 & 19.6 & 18.4 & 18.9 & 19.0 & 17.9 & 0.1 & 0.2 & 0.2 \\
\hline Caribbean ( 13 countries) ${ }^{d}$ & 31.5 & 31.3 & 31.4 & 28.9 & 28.6 & 28.9 & 0.4 & 0.5 & 0.3 \\
\hline Antigua and Barbuda & 24.0 & 23.8 & 20.2 & 23.2 & 22.7 & 20.1 & 0.2 & 0.2 & 0.1 \\
\hline Argentina & 18.2 & 19.4 & 20.9 & 18.1 & 19.3 & 20.8 & 0.1 & 0.1 & 0.2 \\
\hline Bahamas & 19.3 & 18.1 & 19.0 & 19.3 & 18.1 & 18.7 & 0.0 & 0.0 & 0.3 \\
\hline Barbados ${ }^{e}$ & 35.4 & 34.9 & 35.5 & 35.3 & 34.8 & 35.5 & $\ldots$ & & \\
\hline Belize & 30.0 & 29.5 & 26.3 & 25.5 & 26.8 & 24.6 & 1.1 & 0.3 & 0.4 \\
\hline Bolivia (Plurinational State of) ${ }^{f}$ & 32.7 & 32.7 & 31.7 & 31.1 & 31.5 & 30.7 & 0.0 & 0.0 & 0.0 \\
\hline Brazil & 23.2 & 23.8 & 23.5 & 23.2 & 23.8 & 23.5 & $\ldots$ & $\ldots$ & \\
\hline Chile & 27.4 & 26.2 & 20.0 & 27.4 & 26.2 & 19.9 & 0.0 & 0.0 & 0.1 \\
\hline${ }^{9}$ Colombia & 15.0 & 15.7 & 15.3 & 13.5 & 13.6 & 13.0 & 1.5 & 2.1 & 2.3 \\
\hline${ }^{\mathrm{h}}$ Costa & 15.5 & 15.9 & 14.1 & 15.5 & 15.8 & 14.0 & 0.0 & 0.0 & 0.0 \\
\hline Rica Cuba & 46.0 & 49.1 & 48.5 & 43.7 & 47.3 & 46.7 & 2.3 & 1.8 & 1.8 \\
\hline Dominica & 41.8 & 41.2 & 40.6 & 33.6 & 33.4 & 34.5 & 0.1 & 0.0 & 0.0 \\
\hline Ecuador & 18.7 & 25.5 & 22.3 & 18.7 & 25.5 & 22.3 & 0.0 & 0.0 & 0.0 \\
\hline El Salvador & 14.6 & 14.7 & 13.5 & 14.3 & 14.4 & 13.1 & 0.0 & 0.0 & 0.0 \\
\hline Grenada & 27.2 & 28.2 & 26.0 & 26.0 & 25.4 & 24.2 & 0.0 & 0.0 & 0.0 \\
\hline Guatemala & 12.8 & 12.0 & 11.2 & 12.8 & 12.0 & 11.2 & 0.0 & 0.0 & 0.0 \\
\hline Guyana & 26.0 & 25.4 & 27.2 & 22.8 & 21.1 & 23.0 & 0.0 & 0.1 & 0.0 \\
\hline Haiti & 11.3 & 10.8 & 12.1 & 10.8 & 10.6 & 11.7 & 0.0 & 0.0 & 0.0 \\
\hline Honduras & 19.1 & 19.7 & 17.4 & 17.5 & 17.6 & 15.5 & 0.0 & 0.0 & 0.0 \\
\hline Jamaica & 28.7 & 27.1 & 29.9 & 27.2 & 26.2 & 28.3 & 1.0 & 0.2 & 0.7 \\
\hline Mexico & 15.3 & 17.0 & 17.0 & 15.3 & 17.0 & 17.0 & 0.0 & 0.0 & 0.0 \\
\hline Nicaragua & 23.7 & 22.3 & 21.5 & 19.9 & 19.4 & 19.1 & 0.0 & 0.0 & 0.0 \\
\hline Panama & 19.2 & 19.7 & 18.3 & 18.9 & 18.2 & 18.0 & 0.1 & 1.1 & 0.2 \\
\hline Paraguay & 17.6 & 17.3 & 19.6 & 17.2 & 16.9 & 19.2 & 0.0 & 0.0 & 0.4 \\
\hline Peru & 18.2 & 18.1 & 15.6 & 18.1 & 18.0 & 15.5 & 0.1 & 0.1 & 0.1 \\
\hline Dominican Republic & 17.7 & 15.9 & 13.7 & 17.3 & 15.7 & 13.5 & 0.0 & 0.0 & 0.0 \\
\hline Saint Kitts and Nevis ${ }^{i}$ & 41.9 & 41.1 & 42.7 & 37.2 & 35.3 & 36.7 & 2.6 & 4.0 & 1.9 \\
\hline Saint Vincent and the Grenadines & 30.5 & 35.0 & 33.1 & 28.8 & 31.2 & 29.3 & 0.1 & 1.0 & 0.1 \\
\hline Saint Lucia & 27.4 & 30.0 & 30.3 & 27.1 & 29.0 & 29.3 & 0.0 & 0.3 & 0.0 \\
\hline Suriname & 46.6 & 37.2 & 49.1 & 38.3 & 33.4 & 43.3 & 0.0 & 0.0 & 0.0 \\
\hline Trinidad and Tobago & 31.1 & 34.8 & 28.5 & 31.1 & 34.8 & 28.5 & 0.0 & 0.0 & 0.0 \\
\hline Uruguay & 20.5 & 20.0 & 20.4 & 20.5 & 20.0 & 20.4 & 0.0 & 0.0 & 0.0 \\
\hline Venezuela (Bolivarian Republic of) & 29.1 & 24.9 & 21.6 & 29.1 & 24.9 & 21.6 & 0.0 & 0.0 & 0.0 \\
\hline
\end{tabular}

Source: Economic Commission for Latin America and the Caribbean (ECLAC), on the basis of official figures.

a Preliminary figures.

b Simple averages of the figures for 33 countries.

Simple averages. Includes information on 19 countries of Latin America and the Caribbean: Argentina, Bolivarian Republic of Venezuela, Brazil, Chile, Colombia, Costa Rica, Dominican Republic, Ecuador, El Salvador, Guatemala, Haiti, Honduras, Mexico, Nicaragua, Panama, Paraguay, Peru, Plurinational State of Bolivia and Uruguay.

d Simple averages. Includes information on 13 Caribbean countries: Antigua and Barbuda, Bahamas, Barbados, Belize, Dominica, Grenada, Guyana, Jamaica, Saint Kitts and Nevis, Saint Vincent and the Grenadines, Saint Lucia, Suriname and Trinidad and Tobago.

e Non-financial public sector

General government.

Total revenue corresponds to revenue plus sales of physical assets.

Total revenue includes special funds and incorporates accrued revenues.

Federal government. 
Table A-36

LATIN AMERICA AND THE CARIBBEAN: CENTRAL GOVERNMENT FISCAL EXPENDITURE

(Percentages of GDP)

\begin{tabular}{|c|c|c|c|c|c|c|c|c|c|c|c|c|}
\hline & \multicolumn{3}{|c|}{ Total expenditure } & \multicolumn{3}{|c|}{ Current expenditure } & \multicolumn{3}{|c|}{ Capital expenditure } & \multicolumn{3}{|c|}{ Interest } \\
\hline & 2007 & 2008 & $2009^{a}$ & 2007 & 2008 & $2009^{a}$ & 2007 & 2008 & $2009^{a}$ & 2007 & 2008 & $2009^{a}$ \\
\hline Latin America and the Caribbean ( 33 countries) ${ }^{b}$ & 25.6 & 26.3 & 27.8 & 20.1 & 20.7 & 22.3 & 5.4 & 5.5 & 5.4 & 2.7 & 2.5 & 2.7 \\
\hline Latin America and the Caribbean (19 countries) ${ }^{\mathrm{C}}$ & 19.2 & 20.0 & 21.2 & 15.3 & 15.7 & 17.0 & 3.9 & 4.3 & 4.2 & 2.0 & 1.7 & 1.8 \\
\hline Caribbean ( 13 countries) ${ }^{d}$ & 33.1 & 33.3 & 35.4 & 25.6 & 26.1 & 28.5 & 7.4 & 7.1 & 6.9 & 4.0 & 3.9 & 4.1 \\
\hline Antigua and Barbuda & 30.5 & 30.5 & 30.8 & 24.0 & 23.6 & 24.9 & 6.4 & 6.9 & 5.9 & 3.3 & 3.2 & 1.6 \\
\hline Argentina & 17.5 & 18.7 & 22.0 & 15.3 & 16.4 & 19.3 & 2.2 & 2.2 & 2.7 & 2.1 & 2.1 & 2.3 \\
\hline Bahamas & 20.6 & 21.4 & 22.2 & 18.2 & 19.5 & 19.4 & 2.4 & 1.9 & 2.8 & 1.9 & 2.1 & 2.4 \\
\hline Barbados $^{e}$ & 37.2 & 41.3 & 44.7 & 33.7 & 37.3 & 40.7 & 2.9 & 3.5 & 3.5 & 4.6 & 5.6 & 6.0 \\
\hline Belize & 31.2 & 27.9 & 29.1 & 24.9 & 22.7 & 24.9 & 6.3 & 5.2 & 4.3 & 5.3 & 3.9 & 3.6 \\
\hline Bolivia (Plurinational State of) $f$ & 30.5 & 32.7 & 31.5 & 18.7 & 21.8 & 21.6 & 11.7 & 10.9 & 9.9 & 1.3 & 0.8 & 0.9 \\
\hline Brazil & 25.1 & 25.0 & 27.0 & 20.6 & 20.3 & 22.4 & 4.5 & 4.7 & 4.6 & 4.1 & 3.6 & 4.9 \\
\hline Chile & 18.6 & 21.0 & 24.4 & 15.4 & 17.2 & 19.7 & 3.2 & 3.8 & 4.7 & 0.6 & 0.5 & 0.5 \\
\hline${ }^{9}$ Colombia & 17.7 & 18.1 & 19.4 & 15.8 & 15.8 & 17.1 & 1.8 & 2.3 & 2.3 & 3.7 & 3.2 & 3.0 \\
\hline${ }^{\mathrm{h}}$ Costa & 14.9 & 15.7 & 17.5 & 13.6 & 13.5 & 15.7 & 1.3 & 2.2 & 1.8 & 3.1 & 2.2 & 2.1 \\
\hline Rica Cuba & 49.2 & 56.0 & 53.3 & 38.3 & 45.1 & 42.4 & 8.3 & 8.1 & 8.2 & 1.4 & 1.4 & 1.4 \\
\hline Dominica & 40.8 & 44.4 & 43.3 & 28.7 & 29.2 & 28.4 & 12.1 & 15.2 & 14.9 & 3.0 & 2.4 & 1.4 \\
\hline Ecuador & 18.8 & 26.6 & 27.3 & 13.0 & 15.7 & 17.2 & 5.8 & 10.9 & 10.2 & 2.0 & 1.5 & 0.9 \\
\hline El Salvador & 14.8 & 15.3 & 17.2 & 12.3 & 12.6 & 14.4 & 2.6 & 2.7 & 2.9 & 2.4 & 2.3 & 2.5 \\
\hline Grenada & 33.8 & 34.3 & 32.2 & 21.0 & 22.6 & 25.1 & 12.8 & 11.7 & 7.1 & 2.0 & 1.9 & 2.7 \\
\hline Guatemala & 14.3 & 13.6 & 14.3 & 9.5 & 9.2 & 10.2 & 4.8 & 4.5 & 4.1 & 1.5 & 1.4 & 1.4 \\
\hline Guyana & 30.5 & 29.2 & 30.8 & 18.4 & 20.0 & 19.5 & 12.2 & 9.2 & 11.4 & 1.8 & 1.7 & 1.6 \\
\hline Haiti & 12.9 & 12.1 & 13.3 & 10.2 & 9.7 & 12.6 & 2.7 & 2.4 & 0.7 & 0.3 & 0.3 & 0.5 \\
\hline Honduras & 22.2 & 22.2 & 23.5 & 18.0 & 17.4 & 19.0 & 4.1 & 4.8 & 5.2 & 0.7 & 0.6 & 0.7 \\
\hline Jamaica & 32.9 & 34.5 & 37.1 & 28.3 & 30.5 & 33.3 & 4.6 & 4.1 & 3.7 & 11.4 & 12.3 & 14.6 \\
\hline Mexico $^{i}$ & 17.3 & 18.5 & 19.2 & 14.3 & 15.0 & 16.5 & 3.0 & 3.5 & 2.7 & 1.4 & 1.4 & 1.7 \\
\hline Nicaragua & 23.3 & 23.5 & 23.8 & 19.5 & 20.7 & 20.9 & 3.8 & 2.8 & 2.9 & 1.5 & 1.2 & 1.4 \\
\hline Panama & 18.0 & 19.4 & 19.8 & 14.0 & 13.8 & 13.5 & 4.0 & 5.6 & 6.3 & 3.4 & 3.1 & 2.9 \\
\hline Paraguay & 16.7 & 14.8 & 19.6 & 12.9 & 12.2 & 15.0 & 3.8 & 2.7 & 4.6 & 0.8 & 0.6 & 0.6 \\
\hline Peru & 16.4 & 15.9 & 17.4 & 14.2 & 13.6 & 13.6 & 2.1 & 2.4 & 3.8 & 1.6 & 1.4 & 1.2 \\
\hline Dominican Republic & 17.6 & 19.5 & 16.9 & 13.0 & 14.4 & 13.3 & 4.6 & 5.1 & 3.6 & 1.2 & 1.6 & 1.9 \\
\hline Saint Kitts and Nevis ${ }^{j}$ & 44.3 & 41.4 & 42.0 & 36.1 & 34.8 & 36.7 & 8.2 & 6.6 & 5.3 & 8.4 & 8.4 & 8.3 \\
\hline Saint Vincent and the Grenadines & 34.1 & 35.8 & 36.2 & 25.3 & 27.5 & 29.4 & 8.8 & 8.3 & 6.7 & 3.0 & 3.0 & 3.0 \\
\hline Saint Lucia & 29.6 & 29.8 & 32.8 & 21.2 & 23.2 & 25.0 & 8.4 & 6.8 & 7.8 & 3.1 & 2.9 & 3.5 \\
\hline Suriname & 38.6 & 34.9 & 45.4 & 32.6 & 27.6 & 35.2 & 5.9 & 7.4 & 10.1 & 1.9 & 1.0 & 1.5 \\
\hline Trinidad and Tobago & 26.0 & 27.4 & 34.1 & 20.6 & 21.4 & 28.2 & 5.4 & 5.9 & 6.0 & 2.0 & 1.8 & 2.6 \\
\hline Uruguay & 22.1 & 21.1 & 21.8 & 20.6 & 19.3 & 20.3 & 1.5 & 1.8 & 1.6 & 3.7 & 2.8 & 2.7 \\
\hline Venezuela (Bolivarian Republic of) ${ }^{k}$ & 26.0 & 26.1 & 26.7 & 20.0 & 20.0 & 20.8 & 5.9 & 5.8 & 5.5 & 1.5 & 1.3 & 1.3 \\
\hline
\end{tabular}

Source: Economic Commission for Latin America and the Caribbean (ECLAC), on the basis of official figures.

a Preliminary figures.

b Simple averages of the figures for 33 countries.

Simple averages. Includes information on 19 countries of Latin America and the Caribbean: Argentina, Bolivarian Republic of Venezuela, Brazil, Chile, Colombia, Costa Rica, Dominican Republic, Ecuador, El Salvador, Guatemala, Haiti, Honduras, Mexico, Nicaragua, Panama, Paraguay, Peru, Plurinational State of Bolivia and Uruguay.

d Simple averages. Includes information on 13 Caribbean countries: Antigua and Barbuda, Bahamas, Barbados, Belize, Dominica, Grenada, Guyana, Jamaica, Saint Kitts and Nevis, Saint Vincent and the Grenadines, Saint Lucia, Suriname and Trinidad and Tobago.

e Non-financial public sector.

Toral government.

Includes accrued expenditure and floating debt.

Current expendit

Furrent expenditure,

k Total expenditure includes extrabudgetary. 
Table A-37

LATIN AMERICA AND THE CARIBBEAN: CENTRAL GOVERNMENT TAX BURDEN INCLUDING SOCIAL SECURITY CONTRIBUTIONS

(Percentages of GDP)

\begin{tabular}{|c|c|c|c|c|c|c|c|c|c|}
\hline & 2001 & 2002 & 2003 & 2004 & 2005 & 2006 & 2007 & 2008 & $2009^{\circ}$ \\
\hline Latin America and the Caribbean (33 countries) ${ }^{\mathrm{b}}$ & 18.2 & 18.1 & 18.4 & 19.0 & 19.6 & 20.2 & 20.9 & 20.5 & 20.5 \\
\hline Latin America and the Caribbean (19 countries) ${ }^{c}$ & 15.4 & 15.4 & 15.6 & 16.0 & 16.7 & 17.3 & 17.9 & 17.8 & 17.7 \\
\hline Caribbean (13 countries) ${ }^{d}$ & 21.7 & 21.5 & 21.8 & 22.9 & 23.0 & 23.7 & 24.7 & 24.3 & 24.5 \\
\hline Antigua and Barbuda ${ }^{e}$ & 16.9 & 18.1 & 18.9 & 19.4 & 19.5 & 20.8 & 22.1 & 21.3 & 19.3 \\
\hline Argentina $^{f}$ & 20.9 & 19.9 & 23.4 & 26.4 & 26.8 & 27.4 & 29.1 & 30.7 & 31.6 \\
\hline Bahamas $^{e}$ & 15.4 & 13.6 & 13.8 & 13.8 & 14.1 & 15.6 & 16.3 & 17.3 & 15.3 \\
\hline Barbados $^{e}$ & 32.0 & 32.0 & 32.0 & 32.2 & 31.4 & 34.1 & 33.4 & 32.9 & 32.3 \\
\hline Belize $^{e}$ & 18.5 & 19.0 & 18.7 & 19.8 & 20.5 & 21.2 & 22.6 & 22.7 & 21.7 \\
\hline Bolivia (Plurinational State of) ${ }^{f}$ & 17.0 & 17.3 & 17.2 & 19.2 & 20.6 & 20.0 & 20.6 & 21.7 & 22.6 \\
\hline Brazil $^{f}$ & 31.3 & 31.9 & 31.4 & 32.2 & 33.3 & 33.5 & 33.9 & 34.4 & 34.3 \\
\hline Chile & 18.1 & 18.0 & 17.3 & 17.0 & 18.3 & 18.3 & 20.2 & 19.9 & 16.1 \\
\hline Colombia & 13.3 & 13.2 & 13.5 & 14.3 & 14.7 & 15.5 & 15.7 & 15.5 & 15.0 \\
\hline Costa Rica & 13.2 & 13.2 & 13.3 & 13.3 & 13.6 & 14.0 & 15.2 & 15.6 & 13.8 \\
\hline Cuba & 25.9 & 26.6 & 26.9 & 23.3 & 28.7 & 30.0 & 27.7 & 23.3 & 21.2 \\
\hline Dominica $^{e}$ & 22.7 & 23.5 & 25.3 & 26.7 & 28.4 & 29.1 & 30.7 & 30.4 & 31.6 \\
\hline Ecuador & 13.3 & 14.2 & 13.0 & 12.8 & 13.1 & 13.9 & 14.4 & 16.0 & 17.9 \\
\hline El Salvador & 12.3 & 13.0 & 13.3 & 13.3 & 14.0 & 14.9 & 15.0 & 14.6 & 14.0 \\
\hline Grenada $^{e}$ & 22.5 & 22.2 & 23.0 & 22.1 & 23.0 & 23.6 & 24.4 & 23.7 & 22.9 \\
\hline Guatemala & 11.1 & 12.2 & 11.9 & 11.8 & 11.5 & 12.1 & 12.3 & 11.5 & 10.7 \\
\hline Guyana ${ }^{e}$ & 17.8 & 18.5 & 18.1 & 19.4 & 20.2 & 20.1 & 22.0 & 20.2 & 21.6 \\
\hline Haiti e & 7.4 & 8.2 & 8.8 & 8.9 & 9.7 & 10.4 & 10.8 & 10.6 & 11.7 \\
\hline Honduras & 16.6 & 15.4 & 15.5 & 15.5 & 15.7 & 16.2 & 17.6 & 16.3 & 15.7 \\
\hline Jamaica $^{e}$ & 21.6 & 22.0 & 24.2 & 24.3 & 23.4 & 24.0 & 24.6 & 24.2 & 26.7 \\
\hline Mexico & 12.2 & 12.5 & 12.1 & 10.8 & 10.6 & 10.3 & 10.6 & 9.8 & 11.2 \\
\hline Nicaragua & 16.0 & 16.8 & 18.6 & 19.3 & 20.3 & 21.6 & 22.4 & 22.1 & 22.2 \\
\hline Panama & 15.2 & 14.8 & 14.6 & 14.4 & 14.3 & 15.7 & 16.4 & 16.5 & 17.0 \\
\hline Paraguay & 12.0 & 11.2 & 11.3 & 12.9 & 13.0 & 13.1 & 12.6 & 13.0 & 14.5 \\
\hline Peru & 14.3 & 13.8 & 14.5 & 14.7 & 15.2 & 16.7 & 17.1 & 17.2 & 15.2 \\
\hline Dominican Republic & 13.1 & 13.0 & 12.0 & 12.8 & 14.6 & 15.0 & 16.0 & 15.0 & 13.1 \\
\hline Saint Kitts and Nevis ${ }^{e}$ & 20.9 & 22.3 & 23.8 & 25.9 & 28.9 & 28.3 & 28.4 & 27.0 & 26.6 \\
\hline Saint Vincent and the Grenadines ${ }^{e}$ & 24.4 & 27.3 & 26.1 & 25.6 & 25.5 & 26.9 & 26.7 & 28.6 & 27.1 \\
\hline Saint Lucia ${ }^{e}$ & 21.4 & 21.4 & 21.6 & 23.0 & 23.3 & 24.0 & 25.5 & 27.2 & 28.1 \\
\hline Suriname ${ }^{e}$ & 33.0 & 23.4 & 24.4 & 31.8 & 26.7 & 27.5 & 30.0 & 25.7 & 30.6 \\
\hline Trinidad and Tobago ${ }^{e} \mathrm{~g}$ & 15.4 & 15.8 & 13.4 & 14.0 & 13.8 & 13.3 & 14.1 & 14.3 & 14.1 \\
\hline Uruguay & 22.8 & 21.9 & 21.9 & 22.0 & 23.0 & 23.7 & 23.3 & 24.2 & 25.1 \\
\hline Venezuela (Bolivarian Republic of) & 12.2 & 11.2 & 11.9 & 13.3 & 15.9 & 16.4 & 17.1 & 14.3 & 14.5 \\
\hline
\end{tabular}

Source: Economic Commission for Latin America and the Caribbean (ECLAC), on the basis of official figures.

Preliminary figures.

Simple averages of the figures for 33 countries.

Simple averages. Includes information on 19 countries of Latin America and the Caribbean: Argentina, Bolivarian Republic of Venezuela, Brazil, Chile, Colombia, Costa Rica, Dominican Republic, Ecuador, El Salvador, Guatemala, Haiti, Honduras, Mexico, Nicaragua, Panama, Paraguay, Peru, Plurinational State of Bolivia and Uruguay.

d Simple averages. Includes information on 13 Caribbean countries: Antigua and Barbuda, Bahamas, Barbados, Belize, Dominica, Grenada, Guyana, Jamaica, Saint Kitts and Nevis, Saint Vincent and the Grenadines, Saint Lucia, Suriname and Trinidad and Tobago.

Does not include social security contributions.

General government.

$g$ Refers to non-petroleum sector. 
Table A-38

LATIN AMERICA AND THE CARIBBEAN: CENTRAL GOVERNMENT TAX BURDEN AND COMPOSITION OF TAX REVENUES

(Percentages of GDP)

\begin{tabular}{|c|c|c|c|c|c|c|c|c|c|c|c|c|}
\hline \multirow[b]{3}{*}{ Latin America and the Caribbean (33 countries) ${ }^{\mathrm{b}}$} & \multicolumn{2}{|c|}{ Total } & \multicolumn{2}{|c|}{$\begin{array}{c}\text { Social } \\
\text { security } \\
\text { contributions }\end{array}$} & \multicolumn{2}{|c|}{ Direct taxes } & \multicolumn{2}{|c|}{$\begin{array}{l}\text { Income tax and } \\
\text { capital gains tax }\end{array}$} & \multicolumn{2}{|c|}{ Property tax } & \multicolumn{2}{|c|}{$\begin{array}{l}\text { Other direc } \\
\text { taxes }\end{array}$} \\
\hline & \multicolumn{2}{|c|}{$20082009^{a}$} & \multicolumn{2}{|c|}{$20082009^{a}$} & \multicolumn{2}{|c|}{$20082009^{a}$} & \multirow{2}{*}{$\begin{array}{r}2008 \\
6.0\end{array}$} & \multirow{2}{*}{$\begin{array}{c}2009^{a} \\
6.1\end{array}$} & \multicolumn{2}{|c|}{$20082009^{a}$} & \multicolumn{2}{|c|}{20082009} \\
\hline & 20.5 & 20.5 & 2.7 & 2.9 & 6.5 & 6.6 & & & 0.6 & 0.6 & 0.1 & 0.1 \\
\hline Latin America and the Caribbean (19 countries) ${ }^{c}$ & 17.8 & 17.7 & 2.7 & 2.9 & 5.6 & 5.5 & 4.9 & 4.8 & 0.7 & 0.6 & 0.0 & 0.0 \\
\hline Caribbean (13 countries) ${ }^{d}$ & 24.3 & 24.5 & $\ldots$ & $\ldots$ & 8.0 & 8.5 & 7.9 & 8.5 & 0.5 & 0.6 & 0.2 & 0.1 \\
\hline Antigua and Barbuda ${ }^{e}$ & 21.3 & 19.3 & $\cdots$ & $\ldots$ & 3.9 & 3.8 & 3.4 & 3.3 & 0.4 & 0.5 & 0.0 & 0.0 \\
\hline Argentina ${ }^{f}$ & 30.7 & 31.6 & 5.1 & 6.7 & 8.5 & 8.1 & 5.3 & 5.0 & 3.2 & 3.1 & 0.0 & 0.0 \\
\hline Bahamas $^{e}$ & 17.3 & 15.3 & $\ldots$ & $\ldots$ & 1.3 & 1.5 & & $\ldots$ & 1.3 & 1.5 & $\ldots$ & $\ldots$ \\
\hline Barbados ${ }^{e}$ & 32.9 & 32.3 & $\ldots$ & $\ldots$ & 13.9 & 15.7 & 10.7 & 12.3 & 1.7 & 2.2 & 1.4 & 1.2 \\
\hline Belize $^{e}$ & 22.7 & 21.7 & $\ldots$ & $\ldots$ & 7.6 & 7.8 & 7.4 & 7.6 & 0.2 & 0.2 & 0.0 & 0.0 \\
\hline Bolivia (Plurinational State of) ${ }^{f}$ & 21.7 & 22.6 & 1.8 & 1.8 & 5.2 & 7.4 & 4.0 & 6.2 & 1.2 & 1.2 & 0.0 & 0.0 \\
\hline Brazil $^{f}$ & 34.4 & 34.3 & 8.5 & 9.1 & 10.3 & 10.1 & 7.9 & 7.6 & 1.9 & 1.9 & 0.6 & 0.6 \\
\hline Chile & 19.9 & 16.1 & 1.4 & 1.5 & 7.3 & 5.0 & 7.3 & 5.0 & $\ldots$ & $\ldots$ & 0.0 & 0.0 \\
\hline Colombia & 15.5 & 15.0 & 2.0 & 2.0 & 6.5 & 6.6 & 5.1 & 5.6 & 1.3 & 1.0 & 0.0 & 0.0 \\
\hline Costa Rica & 15.6 & 13.8 & 0.3 & 0.3 & 5.0 & 4.8 & 4.4 & 4.1 & 0.6 & 0.7 & 0.0 & 0.0 \\
\hline Cuba & 23.3 & 21.2 & 4.2 & 4.5 & 3.7 & 2.8 & 3.3 & 2.4 & $\ldots$ & $\ldots$ & 0.4 & 0.4 \\
\hline Dominica $^{e}$ & 30.4 & 31.6 & $\ldots$ & $\ldots$ & 6.2 & 6.4 & 5.2 & 5.5 & 1.0 & 0.9 & 0.0 & 0.0 \\
\hline Ecuador & 16.0 & 17.9 & 3.9 & 3.9 & 4.5 & 5.1 & 4.3 & 4.8 & 0.2 & 0.2 & 0.0 & 0.0 \\
\hline El Salvador & 14.6 & 14.0 & 1.6 & 1.7 & 4.6 & 4.6 & 4.5 & 4.5 & 0.1 & 0.1 & 0.0 & 0.0 \\
\hline Grenada $^{e}$ & 23.7 & 22.9 & $\ldots$ & & 6.6 & 6.4 & 5.2 & 5.3 & 1.4 & 1.1 & 0.0 & 0.0 \\
\hline Guatemala & 11.5 & 10.7 & 0.3 & 0.3 & 3.3 & 3.2 & 3.3 & 3.2 & 0.0 & 0.0 & 0.0 & 0.0 \\
\hline Guyana $^{e}$ & 20.2 & 21.6 & $\ldots$ & $\ldots$ & 8.4 & 8.4 & 8.0 & 8.1 & 0.3 & 0.3 & 0.0 & 0.0 \\
\hline Haiti ${ }^{e}$ & 10.6 & 11.7 & $\ldots$ & $\ldots$ & 2.0 & 2.0 & 2.0 & 2.0 & 0.0 & 0.0 & 0.0 & 0.0 \\
\hline Honduras & 16.3 & 15.7 & 1.2 & 1.2 & 5.2 & 4.8 & 5.0 & 4.6 & 0.2 & 0.1 & 0.0 & 0.0 \\
\hline Jamaica $^{\mathrm{e}}$ & 24.2 & 26.7 & $\ldots$ & $\ldots$ & 10.5 & 10.9 & 10.5 & 10.9 & 0.0 & 0.0 & 0.0 & 0.0 \\
\hline Mexico & 9.8 & 11.2 & 1.6 & 1.7 & 5.3 & 5.2 & 5.2 & 5.0 & 0.2 & 0.2 & 0.0 & 0.0 \\
\hline Nicaragua & 22.1 & 22.2 & 4.1 & 4.5 & 5.8 & 6.3 & 5.8 & 6.3 & 0.0 & 0.0 & 0.0 & 0.0 \\
\hline Panama & 16.5 & 17.0 & 5.7 & 5.7 & 5.5 & 6.0 & 4.7 & 5.3 & 0.5 & 0.5 & 0.2 & 0.2 \\
\hline Paraguay & 13.0 & 14.5 & 1.2 & 1.4 & 2.1 & 3.1 & 2.1 & 3.1 & 0.0 & 0.0 & 0.0 & 0.0 \\
\hline Peru & 17.2 & 15.2 & 1.8 & 1.8 & 7.2 & 5.9 & 6.9 & 5.6 & 0.3 & 0.2 & 0.0 & 0.0 \\
\hline Dominican Republic & 15.0 & 13.1 & 0.1 & 0.1 & 4.8 & 4.1 & 3.7 & 3.2 & 1.1 & 0.9 & 0.0 & 0.0 \\
\hline Saint Kitts and Nevis ${ }^{e}$ & 27.0 & 26.6 & $\ldots$ & $\ldots$ & 8.9 & 9.9 & 8.4 & 9.3 & 0.4 & 0.6 & 0.0 & 0.0 \\
\hline Saint Vincent and the Grenadines ${ }^{e}$ & 28.6 & 27.1 & $\ldots$ & & 7.2 & 7.2 & 7.0 & 7.0 & 0.1 & 0.2 & 0.0 & 0.0 \\
\hline Saint Lucia ${ }^{\mathrm{e}}$ & 27.2 & 28.1 & $\ldots$ & $\ldots$ & 8.6 & 8.9 & 8.5 & 8.8 & 0.1 & 0.2 & 0.0 & 0.0 \\
\hline Suriname ${ }^{e}$ & 25.7 & 30.6 & $\ldots$ & $\ldots$ & 13.2 & 16.1 & 12.8 & 15.7 & 0.0 & 0.0 & 0.4 & 0.5 \\
\hline Trinidad and Tobago $^{\text {e } \mathrm{g}}$ & 14.3 & 14.1 & $\ldots$ & $\ldots$ & 8.0 & 7.9 & 8.0 & 7.8 & 0.1 & 0.1 & 0.0 & 0.0 \\
\hline Uruguay & 24.2 & 25.1 & 6.4 & 7.1 & 5.9 & 6.3 & 4.7 & 4.9 & 1.2 & 1.3 & 0.0 & 0.0 \\
\hline Venezuela (Bolivarian Republic of) & 14.3 & 14.5 & 0.8 & 1.0 & 6.9 & 5.6 & 5.9 & 5.6 & 0.9 & 0.0 & 0.0 & 0.0 \\
\hline
\end{tabular}




\begin{tabular}{|c|c|c|c|c|c|c|c|c|c|c|c|c|}
\hline \multirow[b]{3}{*}{ Latin America and the Caribbean (33 countries) ${ }^{b}$} & \multirow{2}{*}{\multicolumn{2}{|c|}{$\begin{array}{l}\text { Indirect taxes } \\
20082009^{a}\end{array}$}} & \multirow{2}{*}{\multicolumn{2}{|c|}{$\begin{array}{c}\begin{array}{c}\text { General } \\
\text { goods and } \\
\text { services taxes }\end{array} \\
20082009^{a}\end{array}$}} & \multirow{2}{*}{\multicolumn{2}{|c|}{$\begin{array}{c}\text { Specific goods } \\
\text { and services } \\
\text { taxes }\end{array}$}} & \multicolumn{2}{|c|}{$\begin{array}{c}\text { Tax on trade } \\
\text { and international } \\
\text { transactions }\end{array}$} & \multirow{2}{*}{\multicolumn{2}{|c|}{$\begin{array}{l}\text { Other indirect } \\
\text { taxes } \\
2009^{a}\end{array}$}} & \multirow{2}{*}{\multicolumn{2}{|c|}{$\begin{array}{l}\text { Othe taxes } \\
20082008\end{array}$}} \\
\hline & & & & & & & \multirow{2}{*}{$\begin{array}{r}2008 \\
3.0\end{array}$} & \multirow{2}{*}{$\begin{array}{c}2009^{a} \\
2.9\end{array}$} & & & & \\
\hline & 12.3 & 11.8 & 7.1 & 6.9 & 1.7 & 1.8 & & & \multirow{2}{*}{$\begin{array}{l}0.4 \\
0.0\end{array}$} & 0.4 & 0.3 & 0.3 \\
\hline Latin America and the Caribbean (19 countries) ${ }^{c}$ & 9.5 & 9.1 & 6.6 & 6.3 & 1.5 & 1.7 & 1.3 & 1.2 & & 0.0 & 0.3 & 0.3 \\
\hline Caribbean (13 countries) $^{d}$ & 16.0 & 15.7 & 7.5 & 7.6 & 2.0 & 2.1 & 5.7 & 5.5 & 1.1 & 1.0 & 0.3 & 0.3 \\
\hline Antigua and Barbuda ${ }^{e}$ & 17.4 & 15.5 & 8.7 & 8.3 & 0.0 & 0.0 & 6.9 & 6.2 & 1.8 & 1.0 & 0.0 & 0.0 \\
\hline Argentina ${ }^{f}$ & 16.7 & 16.3 & 10.7 & 11.0 & 1.7 & 1.8 & 4.4 & 3.5 & 0.0 & 0.0 & 0.4 & 0.5 \\
\hline Bahamas $^{\mathrm{e}}$ & 12.4 & 10.9 & 0.0 & 0.0 & 1.8 & 1.9 & 10.5 & 9.0 & $\ldots$ & $\ldots$ & 3.7 & 3.0 \\
\hline Barbados $^{e}$ & 19.1 & 16.6 & $\ldots$ & $\ldots$ & $\ldots$ & $\ldots$ & 3.0 & 2.6 & 2.0 & 2.2 & $\ldots$ & $\ldots$ \\
\hline Belize $^{e}$ & 15.1 & 13.9 & $\ldots$ & $\ldots$ & 9.1 & 7.9 & 6.0 & 6.0 & $\ldots$ & $\ldots$ & $\ldots$ & $\ldots$ \\
\hline Bolivia (Plurinational State of) ${ }^{f}$ & 14.2 & 12.5 & 10.0 & 9.1 & 3.0 & 2.4 & 1.2 & 1.0 & 0.0 & 0.0 & 0.5 & 0.9 \\
\hline Brazil $^{f}$ & 15.1 & 14.5 & 13.0 & 12.7 & 1.5 & 1.1 & 0.6 & 0.5 & 0.1 & 0.2 & 0.5 & 0.6 \\
\hline Chile & 10.5 & 9.2 & 8.9 & 7.7 & 1.3 & 1.4 & 0.3 & 0.2 & 0.0 & 0.0 & 0.7 & 0.4 \\
\hline Colombia & 6.8 & 6.2 & 5.7 & 5.1 & 0.3 & 0.3 & 0.9 & 0.8 & 0.0 & 0.0 & 0.2 & 0.1 \\
\hline Costa Rica & 10.3 & 8.6 & 6.0 & 4.9 & 3.1 & 2.8 & 1.2 & 0.9 & 0.0 & 0.0 & 0.0 & 0.0 \\
\hline Cuba & 13.9 & 13.1 & 12.6 & 11.9 & 1.3 & 1.2 & 0.0 & 0.0 & 0.0 & 0.0 & 1.4 & 0.9 \\
\hline Dominica $^{e}$ & 24.2 & 25.2 & 17.4 & 18.3 & 0.0 & 0.0 & 6.8 & 6.9 & 0.0 & 0.0 & 0.0 & 0.0 \\
\hline Ecuador & 7.5 & 8.9 & 5.2 & 5.8 & 0.9 & 0.9 & 1.5 & 2.2 & 0.0 & 0.0 & 0.1 & 0.0 \\
\hline El Salvador & 8.1 & 7.4 & 6.6 & 5.9 & 0.7 & 0.8 & 0.8 & 0.7 & 0.0 & 0.0 & 0.3 & 0.4 \\
\hline Grenada $^{e}$ & 17.1 & 16.5 & 9.0 & 8.4 & 0.9 & 1.0 & 6.9 & 6.8 & 0.3 & 0.3 & 0.0 & 0.0 \\
\hline Guatemala & 7.9 & 7.1 & 5.5 & 4.9 & 1.1 & 1.2 & 0.9 & 0.8 & 0.4 & 0.2 & 0.1 & 0.2 \\
\hline Guyana ${ }^{e}$ & 11.7 & 13.0 & 6.1 & 5.6 & 3.4 & 5.2 & 2.0 & 2.0 & 0.2 & 0.2 & 0.2 & 0.2 \\
\hline Haiti ${ }^{e}$ & 6.9 & 7.5 & 3.3 & 3.4 & 0.5 & 0.7 & 3.2 & 3.4 & 0.0 & 0.0 & 1.7 & 2.2 \\
\hline Honduras & 9.9 & 9.7 & 6.2 & 5.3 & 2.5 & 3.6 & 1.1 & 0.8 & 0.0 & 0.0 & 0.0 & 0.0 \\
\hline Jamaica $^{e}$ & 13.6 & 15.8 & 4.0 & 4.3 & 0.5 & 0.8 & 6.6 & 8.2 & 2.6 & 2.5 & 0.0 & 0.0 \\
\hline Mexico & 2.7 & 4.2 & 3.8 & 3.5 & -1.4 & 0.5 & 0.3 & 0.3 & 0.0 & 0.0 & 0.2 & 0.2 \\
\hline Nicaragua & 12.2 & 11.4 & 7.4 & 7.1 & 3.7 & 3.5 & 1.0 & 0.8 & 0.0 & 0.0 & 0.0 & 0.0 \\
\hline Panama & 5.1 & 5.1 & 2.3 & 2.3 & 1.0 & 1.2 & 1.8 & 1.6 & 0.0 & 0.0 & 0.2 & 0.1 \\
\hline Paraguay & 9.5 & 9.8 & 6.1 & 6.3 & 1.9 & 2.1 & 1.4 & 1.4 & 0.0 & 0.0 & 0.2 & 0.1 \\
\hline Peru & 8.1 & 7.3 & 6.5 & 5.7 & 1.0 & 1.1 & 0.5 & 0.4 & 0.1 & 0.2 & 0.2 & 0.2 \\
\hline Dominican Republic & 10.2 & 9.0 & 4.7 & 4.2 & 3.9 & 3.5 & 1.6 & 1.3 & 0.0 & 0.0 & 0.0 & 0.0 \\
\hline Saint Kitts and Nevis ${ }^{e}$ & 18.2 & 16.7 & 8.0 & 7.1 & 1.5 & 1.0 & 6.5 & 6.2 & 2.1 & 2.3 & 0.0 & 0.0 \\
\hline Saint Vincent and the Grenadines ${ }^{e}$ & 21.4 & 19.9 & 13.9 & 13.3 & 0.0 & 0.0 & 5.7 & 5.4 & 1.9 & 1.2 & 0.0 & 0.0 \\
\hline Saint Lucia ${ }^{e}$ & 18.7 & 19.2 & 7.3 & 9.1 & 2.4 & 1.7 & 7.9 & 7.6 & 1.1 & 0.8 & 0.0 & 0.0 \\
\hline Suriname ${ }^{e}$ & 12.5 & 14.5 & 4.0 & 5.3 & 4.4 & 5.3 & 4.1 & 3.9 & 0.0 & 0.0 & 0.0 & 0.0 \\
\hline Trinidad and Tobago $^{\text {e }} \mathrm{g}$ & 6.2 & 6.2 & 4.3 & 4.2 & 0.6 & 0.6 & 1.3 & 1.4 & 0.0 & 0.0 & 0.0 & 0.0 \\
\hline Uruguay & 11.4 & 11.2 & 8.6 & 8.4 & 1.7 & 1.8 & 1.1 & 1.0 & 0.0 & 0.0 & 0.5 & 0.5 \\
\hline Venezuela (Bolivarian Republic of) & 6.7 & 7.9 & 4.7 & 5.9 & 0.9 & 1.1 & 1.1 & 0.9 & 0.0 & 0.0 & 0.0 & 0.0 \\
\hline
\end{tabular}

Source: Economic Commission for Latin America and the Caribbean (ECLAC), on the basis of official figures.

a Preliminary figur.

Simple averages of the figures for 33 countries.

Simple averages. Includes information on 19 countries of Latin America and the Caribbean: Argentina, Bolivarian Republic of Venezuela, Brazil, Chile, Colombia, Costa Rica, Dominican Republic, Ecuador, El Salvador, Guatemala, Haiti, Honduras, Mexico, Nicaragua, Panama, Paraguay, Peru, Plurinational State of Bolivia and Uruguay.

Simple average. Includes information on 13 Caribbean countries: Antigua and Barbuda, Bahamas, Barbados, Belize, Dominica, Grenada, Guyana, Jamaica, Saint Kitts and Nevis, Saint Vincent and the Grenadines, Saint Lucia, Suriname and Trinidad and Tobago.

e Does not include social security contributions.

General government

Refers to non-petroleum sector. 
Table A-39

LATIN AMERICA AND THE CARIBBEAN: CENTRAL GOVERNMENT GROSS PUBLIC DEBT (Percentages of GDP)

\begin{tabular}{|c|c|c|c|c|c|c|c|c|c|}
\hline & 2001 & 2002 & 2003 & 2004 & 2005 & 2006 & 2007 & 2008 & $2009^{a}$ \\
\hline Latin America and the Caribbean ${ }^{b}$ & 44.9 & 58.2 & 57.3 & 50.9 & 42.8 & 35.8 & 29.9 & 28.2 & 30.2 \\
\hline Argentina $^{c}$ & 53.7 & 145.9 & 138.2 & 126.4 & 72.8 & 63.6 & 55.7 & 48.5 & 48.5 \\
\hline Bolivia (Plurinational State of) ${ }^{d}$ & 72.7 & 77.4 & 86.7 & 81.1 & 75.4 & 49.6 & 37.1 & 34.0 & 36.3 \\
\hline Brazil ${ }^{\mathrm{e}}$ & 31.6 & 37.9 & 34.0 & 31.0 & 30.9 & 31.0 & 30.7 & 24.2 & 29.7 \\
\hline Chile $^{f}$ & 14.9 & 15.7 & 13.0 & 10.7 & 7.3 & 5.3 & 4.1 & 5.2 & 6.1 \\
\hline Colombia $^{9}$ & 36.7 & 41.6 & 42.4 & 38.9 & 39.1 & 37.4 & 32.9 & 33.5 & 35.0 \\
\hline Costa Rica & 43.2 & 43.6 & 41.3 & 41.0 & 37.5 & 33.3 & 27.6 & 24.9 & 27.4 \\
\hline Ecuador & 56.8 & 50.7 & 46.2 & 40.8 & 36.1 & 29.5 & 27.7 & 22.9 & 17.4 \\
\hline El Salvador ${ }^{d}$ & 30.7 & 35.2 & 37.2 & 38.1 & 37.3 & 37.3 & 34.5 & 33.4 & 41.7 \\
\hline Guatemala $^{d}$ & 20.2 & 18.4 & 20.9 & 21.4 & 20.8 & 21.7 & 21.3 & 20.1 & 23.3 \\
\hline Haiti $^{h}$ & 46.2 & 60.2 & 57.5 & 46.7 & 44.1 & 36.2 & 33.6 & 36.8 & 38.6 \\
\hline Honduras & 53.9 & 55.5 & 60.7 & 59.6 & 44.7 & 28.7 & 17.3 & 19.9 & 24.3 \\
\hline Mexico $^{i}$ & 20.5 & 21.9 & 22.1 & 20.7 & 20.3 & 20.6 & 21.1 & 24.5 & 28.3 \\
\hline Nicaragua & 109.9 & 133.7 & 137.7 & 100.6 & 92.6 & 69.5 & 43.1 & 39.0 & 44.1 \\
\hline Panama $^{j}$ & 70.1 & 69.0 & 66.6 & 69.6 & 65.1 & 60.3 & 52.3 & 44.4 & 44.5 \\
\hline Paraguay & 41.1 & 59.2 & 44.4 & 38.0 & 31.4 & 23.8 & 16.9 & 14.5 & 15.7 \\
\hline Peru & 34.5 & 43.2 & 43.4 & 40.1 & 36.9 & 30.1 & 26.2 & 24.1 & 23.4 \\
\hline Dominican Republic & & & & & 22.0 & 20.4 & 18.4 & 24.4 & 28.0 \\
\hline Uruguay & 40.8 & 96.2 & 91.9 & 72.7 & 65.4 & 57.8 & 48.9 & 47.7 & 43.3 \\
\hline Venezuela (Bolivarian Republic of) ${ }^{\mathrm{k}}$ & 30.4 & 42.4 & 46.3 & 38.1 & 32.8 & 24.1 & 19.5 & 14.2 & 18.4 \\
\hline
\end{tabular}

Source: Economic Commission for Latin America and the Caribbean (ECLAC), on the basis of official figures.

a Preliminary figures.

Simple averages.

National public administration. As from 2005, does not include debt not presented for swap.

Does not include publicly guaranteed private debt.

Net public debt. Federal government and central bank.

Consolidated.

Central national government.

Does not include public sector commitments to commercial banks.

Federal government.

Does not include domestic floating debt

Non-financial public sector.

Table A-40

LATIN AMERICA AND THE CARIBBEAN: NON-FINANCIAL PUBLIC-SECTOR GROSS PUBLIC DEBT (Percentages of GDP)

\begin{tabular}{|c|c|c|c|c|c|c|c|c|c|}
\hline & 2001 & 2002 & 2003 & 2004 & 2005 & 2006 & 2007 & 2008 & $2009^{a}$ \\
\hline Latin America and the Caribbean ${ }^{b}$ & 48.5 & 62.7 & 61.4 & 54.2 & 46.5 & 39.6 & 33.6 & 31.6 & 33.2 \\
\hline Argentina $^{c}$ & 64.8 & 184.4 & 156.9 & 143.3 & 87.6 & 76.3 & 66.7 & 57.8 & 57.3 \\
\hline Bolivia (Plurinational State of) ${ }^{d}$ & 76.7 & 80.2 & 89.5 & 83.9 & 78.1 & 52.4 & 40.0 & 36.8 & 39.5 \\
\hline Brazil e & 52.2 & 60.6 & 54.9 & 50.6 & 38.5 & 47.0 & 45.1 & 38.4 & 42.8 \\
\hline Chile $^{f}$ & 20.2 & 22.1 & 19.5 & 16.8 & 13.0 & 10.6 & 9.1 & 12.0 & 12.7 \\
\hline Colombia $^{g}$ & 51.6 & 58.4 & 56.5 & 51.6 & 50.1 & 47.3 & 43.8 & 42.9 & 45.1 \\
\hline Costa Rica & 43.2 & 45.1 & 45.6 & 46.9 & 42.9 & 38.4 & 31.8 & 29.9 & 34.1 \\
\hline Ecuador $^{d}$ & 62.7 & 54.7 & 49.5 & 43.7 & 38.9 & 32.0 & 30.2 & 25.0 & 19.5 \\
\hline El Salvador ${ }^{d}$ & 33.6 & 38.6 & 40.3 & 40.5 & 39.4 & 39.5 & 36.5 & 35.8 & 44.2 \\
\hline Guatemala $^{d}$ & 21.7 & 19.6 & 22.0 & 22.4 & 21.5 & 21.9 & 21.6 & 20.4 & 23.6 \\
\hline Haiti h & 50.7 & 66.5 & 63.5 & 51.1 & 47.5 & 38.7 & 35.9 & 37.8 & 28.4 \\
\hline Honduras & 53.5 & 55.1 & 59.9 & 59.4 & 44.8 & 30.0 & 18.2 & 18.9 & 22.6 \\
\hline Mexico $^{i}$ & 24.1 & 25.7 & 26.1 & 24.2 & 22.9 & 22.6 & 22.9 & 27.0 & 35.2 \\
\hline Nicaragua & 111.3 & 134.1 & 138.0 & 100.7 & 92.8 & 70.0 & 44.0 & 40.1 & 45.3 \\
\hline Panama & 71.1 & 69.4 & 67.0 & 70.4 & 66.2 & 61.0 & 52.9 & 45.0 & 45.1 \\
\hline Paraguay & 44.0 & 63.0 & 46.9 & 41.7 & 32.8 & 24.8 & 19.9 & 17.3 & 17.8 \\
\hline Peru ${ }^{j}$ & 44.2 & 45.7 & 47.4 & 41.8 & 38.2 & 31.3 & 27.2 & 24.5 & 23.8 \\
\hline Dominican Republic ${ }^{k}$ & 19.7 & 23.1 & 39.7 & 25.2 & 26.5 & 23.7 & 21.5 & 25.3 & 28.6 \\
\hline Uruguay & 45.6 & 103.3 & 97.9 & 76.9 & 68.6 & 61.1 & 52.1 & 51.1 & 47.0 \\
\hline Venezuela (Bolivarian Republic of) & 30.4 & 42.4 & 46.3 & 38.1 & 32.8 & 24.1 & 19.5 & 14.2 & 18.4 \\
\hline
\end{tabular}

Source: Economic Commission for Latin America and the Caribbean (ECLAC), on the basis of official figures.

a Preliminary figures.

Simple averages.

Up to 2002 the figures refer to national public-sector debt plus provincial debt. From 2003 on, the figures are consolidated.

Refers to the external debt of the non-financial public-sector and central-government domestic debt.

Net public debt. Public sector.

Consolidated.

Consolidated non-financial public sector.

Does not include public sector commitments to commercial banks.

Includes public sector external debt and federal government domestic deb

Includes local and regional government debt owed to Banco de la Nación.

Public sector. 
Table A-41

LATIN AMERICA AND THE CARIBBEAN: SUBNATIONAL GOVERNMENT FISCAL INDICATORS

(Percentages of GDP)

\begin{tabular}{|c|c|c|c|c|c|c|c|c|c|}
\hline & & 2001 & 2002 & 2003 & 2004 & 2005 & 2006 & 2007 & $2008^{a}$ \\
\hline \multirow[t]{6}{*}{ Argentina } & Provinces & & & & & & & & \\
\hline & Total revenue & 11.2 & 10.4 & 11.3 & 12.8 & 13.4 & 13.5 & 13.9 & 13.9 \\
\hline & Total expenditure & 13.6 & 10.9 & 10.9 & 11.8 & 13.1 & 13.4 & 14.0 & 14.4 \\
\hline & Primary balance & -1.5 & -0.0 & 0.9 & 1.4 & 0.7 & 0.5 & 0.2 & -0.3 \\
\hline & Overall balance & -2.4 & -0.5 & 0.4 & 1.0 & 0.3 & 0.1 & -0.1 & -0.5 \\
\hline & Public debt & 11.2 & 21.9 & 18.8 & 16.8 & 14.8 & 12.8 & 11.0 & 9.2 \\
\hline \multicolumn{10}{|c|}{ Bolivia (Plurinational State of) } \\
\hline & \multicolumn{9}{|l|}{ Regional governments } \\
\hline & Total revenue & 7.8 & 8.2 & 7.7 & 8.5 & 10.2 & 12.1 & 12.3 & 11.3 \\
\hline & Total expenditure & 7.9 & 7.9 & 7.3 & 8.0 & 8.1 & 10.2 & 11.2 & 10.8 \\
\hline & Primary balance & 0.1 & 0.5 & 0.6 & 0.7 & 2.3 & 2.1 & 1.3 & 0.7 \\
\hline & Overall balance & -0.2 & 0.3 & 0.4 & 0.6 & 2.1 & 1.9 & 1.1 & 0.5 \\
\hline & Public debt & 0.9 & 1.1 & 1.2 & 1.5 & 1.5 & 1.2 & 1.1 & 1.1 \\
\hline \multirow[t]{6}{*}{ Brazil } & States & & & & & & & & \\
\hline & Ingreso total Gasto & 12.9 & 12.8 & 12.3 & 12.3 & 12.8 & 12.9 & 12.9 & 13.9 \\
\hline & total Resultado & 12.7 & 12.7 & 12.0 & 11.9 & 12.3 & 12.5 & 12.2 & 13.1 \\
\hline & primario ${ }^{b}$ Resultado & 0.3 & 0.3 & 0.6 & 0.7 & 0.7 & 0.6 & 0.9 & 0.9 \\
\hline & global ${ }^{\mathrm{b}}$ Deuda & -0.4 & -0.4 & -0.1 & 0.1 & 0.0 & -0.1 & 0.4 & 0.4 \\
\hline & pública $^{\mathrm{c}}$ & 17.6 & 19.8 & 18.6 & 18.1 & 16.3 & 15.4 & 14.0 & 13.8 \\
\hline \multirow[t]{5}{*}{ Chile } & Municipalities Total & & & & & & & & \\
\hline & revenue Total & 3.2 & 3.3 & 3.1 & 2.7 & 2.9 & 2.7 & 2.7 & 2.9 \\
\hline & expenditure & 3.2 & 3.3 & 3.1 & 2.8 & 2.8 & 2.5 & 2.6 & 2.8 \\
\hline & Primary balance & 0.0 & 0.0 & 0.0 & -0.0 & 0.2 & 0.2 & 0.1 & 0.0 \\
\hline & Overall balance & 0.0 & 0.0 & 0.0 & -0.0 & 0.2 & 0.2 & 0.1 & 0.0 \\
\hline \multirow[t]{6}{*}{ Colombia } & Departments and municipalities & & & & & & & & \\
\hline & Total revenue & 7.2 & 7.9 & 8.2 & 8.2 & 8.3 & 8.1 & 8.1 & 8.1 \\
\hline & Total expenditure & 7.2 & 7.8 & 7.9 & 7.5 & 8.0 & 8.3 & 8.6 & 7.8 \\
\hline & Primary balance & 0.4 & 0.4 & 0.5 & 0.9 & 0.5 & -0.0 & -0.3 & 0.5 \\
\hline & Overall balance & 0.1 & 0.1 & 0.3 & 0.7 & 0.3 & -0.2 & -0.5 & 0.3 \\
\hline & Public debt & 3.4 & 3.1 & 2.4 & 1.8 & 1.7 & 1.5 & 1.6 & 1.4 \\
\hline \multirow[t]{5}{*}{ Costa Rica } & Local governments & & & & & & & & \\
\hline & Total revenue & 0.9 & 0.8 & 0.8 & 0.8 & 0.8 & 0.9 & 0.9 & 0.9 \\
\hline & Total expenditure & 0.8 & 0.8 & 0.8 & 0.8 & 0.8 & 0.8 & 0.9 & 1.1 \\
\hline & Primary balance & 0.1 & 0.1 & 0.1 & 0.0 & -0.0 & 0.1 & 0.0 & -0.2 \\
\hline & Overall balance & 0.0 & 0.0 & 0.1 & -0.0 & -0.1 & 0.0 & -0.0 & -0.2 \\
\hline \multirow[t]{5}{*}{ Cuba } & Local governments & & & & & & & & \\
\hline & Total revenue & 15.9 & 17.3 & 17.5 & 17.9 & 20.8 & 21.3 & 21.3 & 23.4 \\
\hline & Total expenditure & 15.9 & 17.3 & 17.5 & 17.9 & 20.8 & 21.3 & 21.3 & 23.4 \\
\hline & Primary balance & 0.0 & 0.0 & 0.0 & 0.0 & 0.0 & 0.0 & 0.0 & 0.0 \\
\hline & Overall balance & 0.0 & 0.0 & 0.0 & 0.0 & 0.0 & 0.0 & 0.0 & 0.0 \\
\hline \multirow[t]{5}{*}{ Ecuador } & Provincial councils and municipalities & & & & & & & & \\
\hline & Total revenue & 3.9 & 4.0 & 3.7 & 4.3 & 4.0 & 4.1 & 7.0 & 3.7 \\
\hline & Total expenditure & 3.3 & 3.8 & 3.4 & 4.2 & 3.7 & 4.1 & 4.5 & 4.4 \\
\hline & Primary balance & 0.6 & 0.2 & 0.3 & 0.1 & 0.3 & 0.1 & 2.6 & -0.7 \\
\hline & Overall balance & 0.6 & 0.2 & 0.3 & 0.1 & 0.3 & 0.0 & 2.5 & -0.7 \\
\hline \multirow[t]{6}{*}{ Mexico } & State governments and federal district & & & & & & & & \\
\hline & Total revenue & 7.7 & 7.7 & 8.0 & 7.8 & 8.2 & 8.4 & 8.4 & 8.9 \\
\hline & Total expenditure & 7.8 & 7.9 & 7.9 & 7.6 & 8.0 & 8.2 & 8.3 & 8.8 \\
\hline & Primary balance & 0.0 & -0.1 & 0.1 & 0.2 & 0.2 & 0.3 & 0.2 & 0.2 \\
\hline & Overall balance & -0.0 & -0.2 & 0.0 & 0.1 & 0.1 & 0.2 & 0.1 & 0.1 \\
\hline & Public debt ${ }^{d}$ & 1.6 & 1.7 & 1.6 & 1.5 & 1.6 & 1.5 & 1.8 & 2.0 \\
\hline \multirow[t]{5}{*}{ Paraguay } & Provincial governments & & & & & & & & \\
\hline & Total revenue & 0.4 & 0.3 & 0.3 & 0.5 & 0.5 & 0.5 & 0.5 & 0.4 \\
\hline & Total expenditure & 0.4 & 0.2 & 0.3 & 0.5 & 0.5 & 0.5 & 0.4 & 0.3 \\
\hline & Primary balance & 0.0 & 0.0 & -0.0 & 0.0 & -0.0 & -0.0 & 0.1 & 0.1 \\
\hline & Overall balance & 0.0 & 0.0 & -0.0 & 0.0 & -0.0 & -0.0 & 0.1 & 0.1 \\
\hline \multirow[t]{5}{*}{ Peru } & Local governments & & & & & & & & \\
\hline & Total revenue & 2.1 & 2.1 & 2.2 & 2.3 & 2.5 & 2.7 & 3.7 & 3.6 \\
\hline & Total expenditure & 2.0 & 2.0 & 2.1 & 2.2 & 2.2 & 2.6 & 2.6 & 3.6 \\
\hline & Primary balance & 0.1 & 0.1 & 0.2 & 0.1 & 0.3 & 0.1 & 1.1 & 0.0 \\
\hline & Overall balance & -0.0 & 0.1 & 0.1 & 0.1 & 0.3 & 0.1 & 1.1 & 0.0 \\
\hline
\end{tabular}

Source: Economic Commission for Latin America and the Caribbean (ECLAC), on the basis of official figures.

a Preliminary figures.

The primary and overall balances do not include financial resources (credit operations and disposal of assets)

Includes states and municipalities.

d Includes federal and municipal entities. 


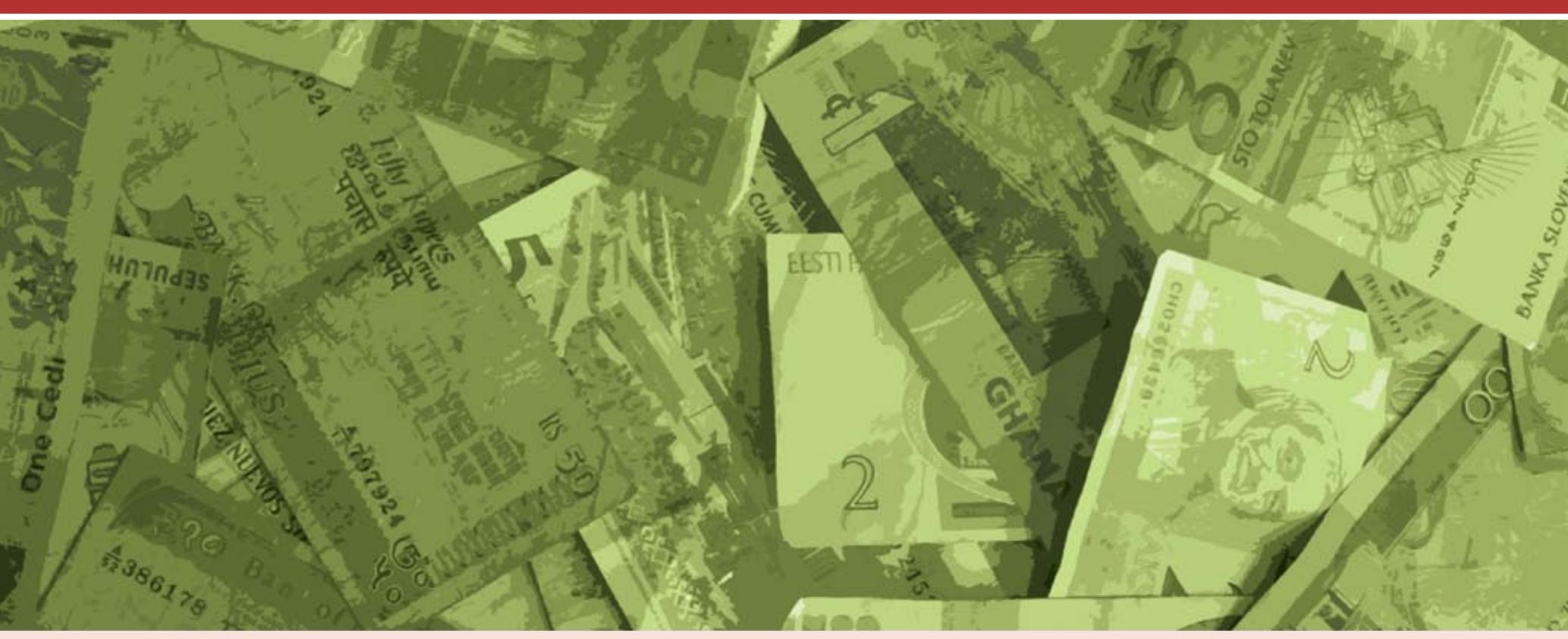

\section{Imprint}

Deutsche Gesellschaft für

Internationale Zusammenarbeit (GIZ) $\mathrm{GmbH}$

Dag-Hammarskjöld-Weg 1-5

65760 Eschborn/Germany

$T+49619679-0$

$F+49619679-1115$

$E$ info@giz.de

l www.giz.de 